Portland State University

PDXScholar

$1-1-2002$

\title{
A Linguistic Evaluation of the Somali Women's Self Sufficiency Project
}

Ann Marie Kasper

Portland State University

Follow this and additional works at: https://pdxscholar.library.pdx.edu/open_access_etds Let us know how access to this document benefits you.

\section{Recommended Citation}

Kasper, Ann Marie, "A Linguistic Evaluation of the Somali Women's Self Sufficiency Project" (2002). Dissertations and Theses. Paper 738.

https://doi.org/10.15760/etd.738

This Thesis is brought to you for free and open access. It has been accepted for inclusion in Dissertations and Theses by an authorized administrator of PDXScholar. Please contact us if we can make this document more accessible: pdxscholar@pdx.edu. 


\section{THESIS APPROVAL}

The abstract and thesis of Ann Marie Kasper for the Masters of Arts in Teaching English to Speakers of Other Languages were presented February 7, 2002, and accepted by the thesis committee and the department.

COMMITTEE APPROVALS:
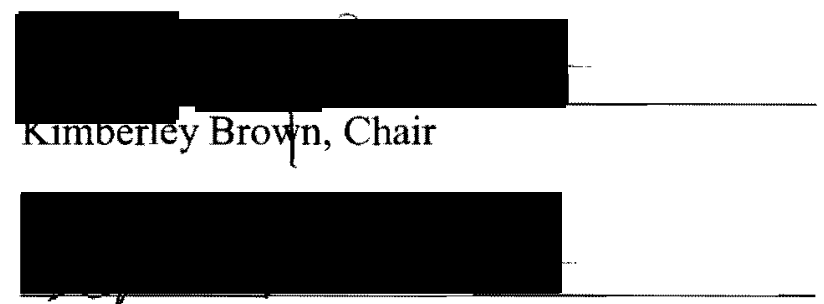

Stephen Reder

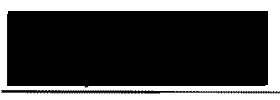

Grant Farr

Representative of the Office of Graduate Studies

DEPARTMENT APPROVAL:

Stephen Reder, Chair

Department of Applied Linguistics 


\begin{abstract}
An abstract of the thesis of Ann Marie Kasper for the Master of Arts in Teaching English to Speakers of Other Languages presented February 7, 2002.
\end{abstract}

Title: A Linguistic Evaluation of the Somali Women's Self Sufficiency Project

This thesis evaluated a program of the Lutheran Community Services of Oregon, an English as a Second Language training program for Somali refugee women. This study examined the English test results and questionnaires of 28 pairs of Somali women and North American volunteers involved in tutoring.

The evaluation included communicating with the Somali women, North American tutors, and Lutheran Community Services staff. The researcher created a literacy test, piloted it, and created questionnaires with the assistance of the staff.

Before the tutoring began, the researcher created a needs assessment for the Somali participants and visited each Somali woman's home with a Somali interpreter to administer the initial student questionnaire, B.E.S.T. Test, Written Form Test, and needs assessment. The researcher administrated the initial questionnaire to the tutors.

Next, the researcher observed the literacy and cultural trainings for the tutors and observed three pairs of tutors and students during tutoring sessions at the students' homes. The researcher attended an informal party for tutors and staff during the middle of the program and administrated the mid-term questionnaire at 
the party and over the phone. The evaluator discussed the program with the staff every couple months.

The final step was going to each Somali woman's home to conduct the final student questionnaire, B.E.S.T. Test, Written Form Test. The final tutor questionnaire was completed over the phone.

The researcher and Lutheran Community Services staff presented the findings at the 2000 Oregon Teachers of English to Speakers of Other Languages (ORTESOL) Conference.

Some of the more significant findings about creating effective programs are that programs for pre-literate refugees should use quantitative and qualitative methods of evaluation and should offer a non-threatening atmosphere for pre-literate adult refugees. Arranging for students to study in their own homes with tutors has positive as well as negative points. The views and languages all of the stakeholders during an evaluation should be considered. It is recommended that programs make materials specifically for their participants, create and offer literacy training specifically made to help tutors teach the targeted populations, and include cultural training for the students and tutors. 
A LINGUISTIC EVALUATION OF THE SOMALI WOMEN'S

SELF SUFFICIENCY PROJECT

by

ANN MARIE KASPER

A thesis submitted in partial fulfillment of the

requirements for the degree of

\section{MASTERS OF ARTS}

in

TEACHING ENGLISH TO SPEAKERS OF OTHER LANGUAGES

Portland State University

2002 


\section{ACKNOWLEGEMENTS}

I would first like to thank the gracious Somali women who allowed me to enter their homes and put them though the English and literacy tests. The testing was obviously uncomfortable for them. I am forever in awe of witnessing their raw courage to survive, to raise their children the best they can in an unfamiliar atmosphere (and many without the aid of a husband), and to maintain their dignity in a totally different culture and language. I would also like to extend thanks to the tutors and staff at Lutheran Community Services, especially Debbie Fisher who suggested that I examine the Somali program.

It has been true privilege to discuss the thesis and world issues with Kim Brown, my advisor. It is rare to find such a person in academia whose work leads to making the world a better place for refugees. I am also grateful to my thesis committee members Grant Farr and Steve Reder.

Thank you to my editors, Louise and Gary Kasper. I would also like to thank the visiting international students and teachers who lived with me and the thesis: Yuki Komazawa (Japan), Kim and Jun Suk Oh (Korea), Jeong Gil (Taiwan), Li-lin Liu (Taiwan), Satoko Kamiya (Japan), Hiroko Abe (Japan), Sung-Eun Lim (Korea), Ni Mingua (China), Mazin Al-Dawoo (Saudi Arabia), Akiko Kuriyama (Japan), Khalfan Alshamisi (United Arab Emerites), Parviz Mohtaj (Iran), Ferran Ribo (Spain), Koji Shimada (Japan), Emiko Mochizuki (Japan), Hitomi Yamaguchi (Japan), Harumi Matsumoto (Japan), and Jared Lin (Taiwan). 
Finally, thank you to Mustafa Kakarash, who taught me firsthand about the heartache of living the refugee experience. He demonstrated to me, as the Somali women did, that the human spirit could remain strong and hopeful even when faced with impossible circumstances. 


\section{TABLE OF CONTENTS}

\section{Page}

ACKNOWLEDGEMENTS

ii

LIST OF TABLES

$\mathrm{x}$

LIST OF FIGURES

xiii

\section{CHAP'TER}

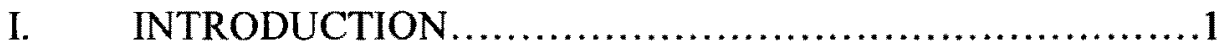

Language Instruction for the Somali Women..................2

Statement of the Problem......................................2

Significance of the Evaluation................................

Guiding Research Questions for the Evaluation.................3

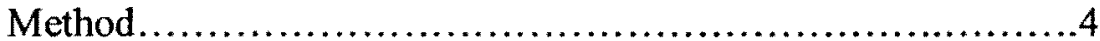

Definitions..............................................4

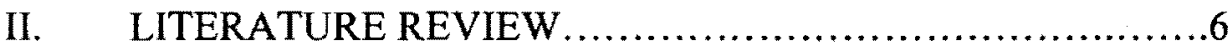

Program Evaluation Types..................................8

Product Evaluation.......................................... 10

Pre and Post Tests - Examining Language Abilities.....10

Process Evaluations..................................13

Affective Factors in Process Evaluation.................16

Process Evaluation Observations......................17

Process Evaluation Questionnaires...................17

Process Evaluation Interviews.......................18 
Alternative Methods to Measure Outcomes.............. 18

Components of the Somali Pathways Project....................19

The Problem Addressed ...........................................19

The Persons Served - Somali Female Participants of the

Pathway Program.......................................22

Cultural Information About the Benadir.................23

Clan and Community...............................25

Somali Women, Clothing and U.S. Culture..............27

Somali Women and Human Rights.......................27

Somali Women and Religion..........................28

Journey as Refugees to the United States................28

Language and Literacy in Somalia.......................31

Somali Pronunciation.................................32

Services Provided - Literacy Instruction Models..................33

The Evaluation Context -Motivation to Learn English .....34

Validity of English Language Testing...................36

Volunteers in Language Programs........................36

Acquiring Literacy Skills...............................37

Language Outcomes as Outlined in Oregon - State of

Oregon English as a Second Language Litreacy

Competencies. 39

The Expected Outcomes 
Ti

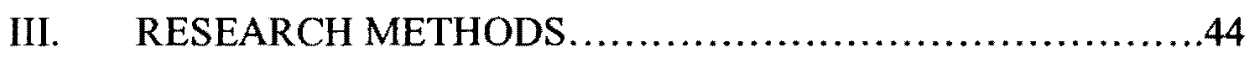

Guiding Research Questions.................................44

General Design of the Study................................44

Project Location and Design.................................47

Instruments...........................................48

Quantitative Methodology..................................48

Tests Used for Evaluation ........................49

The B.E.S.T. Test -Oral Skills........................49

B.E.S.T. Test Form B................................53

Alphabet and Literacy Test in English....................54

The Alphabet Test................................55

Literacy Test ......................................55

Qualitative Methodology.....................................56

The Student Pre and Post-Survey......................58

The Tutor and Staff Pre and Post-Survey.................58

The Tutor Mid-Term Questionnaire....................58

Tutoring Observations..................................59

The Population - The Benadir from Somalia Who Reside in

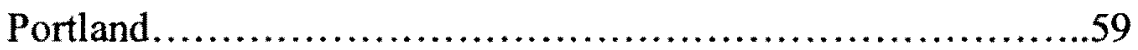

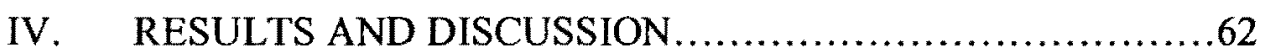


The Total Number of Tutoring Hours Completed..................64

The Pre and Post Surveys for the Somali Women.................65

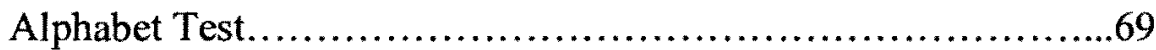

Literacy Self-Reported Abilities and Tests........................71

Affective Factors .............................................. 73

Student Self-Reported Progress, Study Habits and

Achievement of Goals.................................74

The Tutor and Staff Pre and Post-Survey.......................76

Affective Factors........................................76

Experience in Africa ..................................79

ESL and Literacy Tutoring Experience ...................80

Comments on Working with the Somali Women ..........81

Tutor's Assessment of Lutheran Community Services

Trainings............................................... 82

Tutors' Assessment of Total Tutoring Program.............83

Administration of the BEST Pre and Post Tests.....................86

THE B.E.S.T. TEST .................................... 88

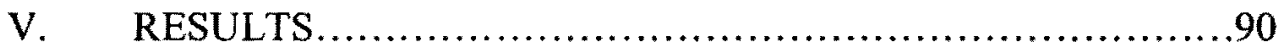

Results................................................... 90 
The State of Oregon.......................................90

Factors of Success...................................... 93

Test Results............................................. 94

Influence of Tutor's Background..........................97

Tutors' Perceptions.........................................99

Materials and Curriculum....................................99

Literacy Training.............................................

Cultural Training ............................................. 100

Student Perceptions....................................... 100

Lutheran Community Services Staff Perceptions...............103

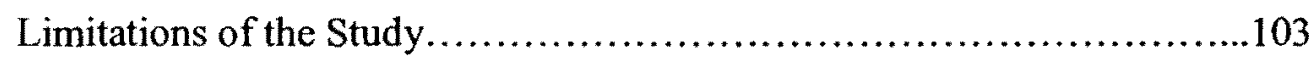

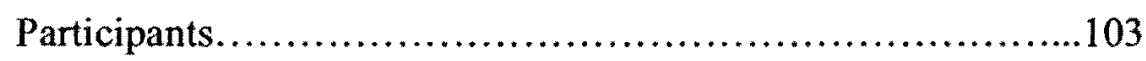

Cultural Factors............................................103

Lack of Test Taking Experience............................ 104

Interpretation.............................................. 104

The Testing Atmosphere..................................... 104

Evaluations of Tutoring Programs.................................... 105

Recommendations Suggestions for Further Research and Implications

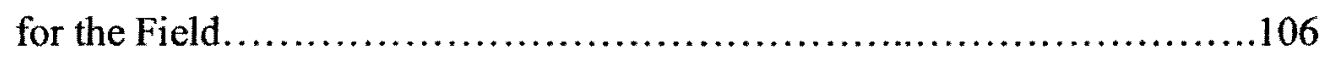

Suggestions for Future Research.....................................

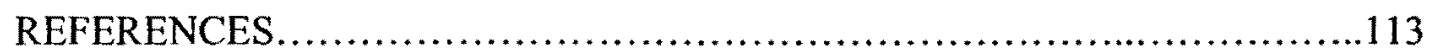




\section{APPENDICES}

A Consent Forms: Somali Women and North American Tutors and Lutheran Family Services Staff.

B Survey Instruments: Somali Women Before and After the Program and North American Tutors Before and After the Program........120

C Literacy Test for Somali Women..............................125

D Individual Test Score Sheets for Somali Women..................127

E Notes From the Tutors' Dinner Party ..........................208

F Mid-Term Tutors Questions and Answers ....................213

G Tutoring Observations.....................................224

H Tutors' Final Comments.......................................2237

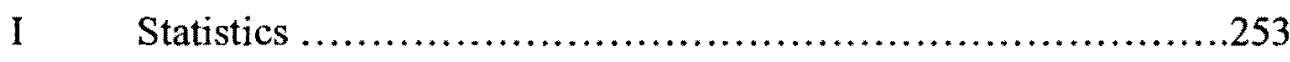




\section{LIST OF TABLES}

\section{Page}

1 Somali Woman's Pathways to Remove Barriers Project

Evaluation Timeline.

2 Somali Woman's Pathway English Proficiency and Literary

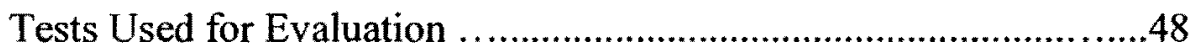

3 B.E.S.T. Test Score Levels and Predicted Abilities.....................53

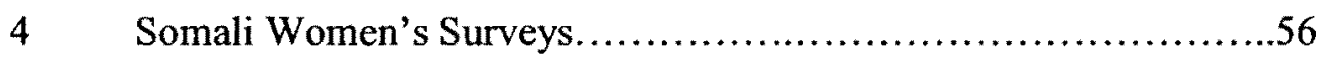

$5 \quad$ Tutors' and Staff Surveys and Questionnaires.......................57

6 Program Results - Amount of Tutoring Hours Completed..........63

$7 \quad$ Percentage of Tutoring Hours Completed..............................64

8 Perception of Difficulty of Learning English........................66

9 Self-Reported Ability to Read and Write in Somali..................67

10 Numbers of Somali Women Who Studied English in the

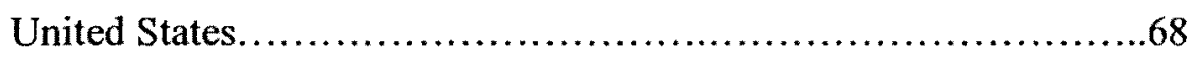

11 Length of Study of English in the United States ...................68

12 Places Where the Somali Women Studied English in the United

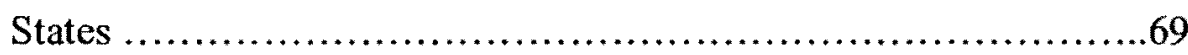

13 Self-Reported Ability to Read in English...........................69

14 Self-Reported Ability to Write the Alphabet in English .............70

$15 \quad$ Alphabet Test Scores....................................... 71

16 Self-Reported Ability to Write Sentences in English ................72 
17 Self-Reported Ability to Fill Out a Job Application in English.......72

18 Self-Reported Ability to Speak on the Phone in English..............73

19 Family Encourages the Student to Learn English...................73

20 Student is Looking Forward to Meeting Tutor..................... 74

21 Student Reported that Tutor was a Good Teacher..................74

22 Student Studied Ability to Write the Alphabet in English ...........75

23 Student Report to Have Achieved Her Goals........................75

24 Self-Reported Ability to Write the Alphabet in English..............75

$25 \quad$ Students' Goals................................................. 76

26 Numbers of Tutors Who Think English Will Be Difficult to Teach..77

27 Numbers of Tutors Who Feel Comfortable With People Who Do Not Speak English..................................................77

28 Numbers of Tutors Who Feel Comfortable Entering a Somali Household..........................................................77

29 Numbers of Tutors Who Feel Comfortable Entering a Somali Household.................................................78

30 Numbers of Tutors Who Plan to Spend More Than One Hour a Day to Prepare Lessons.........................................78

31 Numbers of Tutors Who Can Read and Write in a Foreign Language.....................................................78

32 Numbers of Tutors Who Had Experience Assisting Someone to Fill Out a Job Application.............................................79

33 Numbers of Tutors Who Had Experience Working with Refugees...................................................79

34 Numbers of Tutors Had Traveled to Africa...........................79 
35 The Places the Tutors Visited in Africa............................ 80

36 Numbers of Tutors Who Had Tutoring Experience..................80

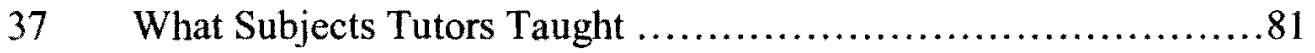

38 The Populations the Tutors Had Worked With......................81

39 Numbers of Tutors Whose Students Studied Outside of Tutoring Sessions.........................................................82

40 Numbers of Tutors Who Reported Their Students Achieved Their Goals............................................................82

41 Numbers of Tutors Who Thought That the E.S.L. Training was Adequate.

42 Numbers of Tutors Who Thought That the Literacy Training was Adequate

43 Numbers of Tutors Who Thought That the Cultural Training was Adequate.

44 Numbers of Tutors Who Liked the Program's

Cause.........................................................83

45 Numbers of Tutors Who Liked the Program's Content...............84

46 Numbers of Tutors Who Wanted to Continue Tutoring..............84

$47 \quad$ B.E.S.T. Test Scores........................................ 85 



\section{CHAPTER ONE}

Introduction

The purpose of this study is to examine an English as a Second Language Program designed for Somali female refugees in Portland, Oregon and to examine methods of evaluation of refugee programs. In 1996, I found myself with the task of finding housing, food, and clothing for more than 100 Somali refugees coming out of Kenya. I scrambled to find sponsors. When we picked the families up at the airport, some of the children and women became scared as they were faced with trying to use an escalator for the first time. None of the women who I resettled spoke English and the time of their arrival and five years later, many of the women's language skills had not improved. Lutheran Community Services created a tutoring program for the Somali female refugees in Oregon and called it Somali Women's Pathway to Remove Barriers Project. The director of the Pathways to Women's suggested that I complete an evaluation of the program. She was interested in discovering if the program worked for the women and what needed improvement.

I was interested in helping with the program because I had worked with some of the Somali women when they first arrived in Portland. I was the sponsorship developer for one of the local refugee resettlement agencies.

For me, it was interesting to discover how the North American tutors and the Somali women would interact. Most of the interaction that I had observed between the church sponsors and the Somali women was superficial at the its best due to the lack of a common language. The religious differences also created some distance 
between most of the sponsors and the Somali families. The ones who ended up receiving the most attention from the sponsors were the children because they acquired English very quickly and adapted to the culture in the U.S. more easily than their parents.

I also observed that besides shopping for food, the Somali women usually stayed at their homes. Transportation and childcare were very difficult to arrange.

\section{Language Instruction for the Somali Women}

The Somali refugees for whom the tutoring program was designed were enrolled in English as a Second Language classes through the welfare system in Portland. They were required to attend classes so that they could receive benefits and support their families. However, they were not acquiring many language skills because they encountered several barriers to learning another language. These barriers include poor transportation access, being single mothers and worrying about their children while they were at class as well as trying to have everything in the household such as food and laundry for several children prepared before attending classes.

\section{Statement of the Problem}

One problem is there are few models of evaluations of programs for preliterate women and especially women from Somalia. The evaluation was developed as a formative one and procedures were added during the process. The types of evaluation used here include: pre, mid-program and post surveys of the tutors and the staff, pre and post language testing (both oral and written), some 
observation of the cultural and language training and of some of the one-on-one tutoring, and the collection of comments from the staff during the entire process.

Significance of the Evaluation

Most English as a Second Language programs for refugees in Oregon are not evaluated in terms of student test scores or answers on questionnaires. Rather, the success of the program is determined by the attendance rate of the refugees and the proper use of the allocated funds. This evaluation includes language tests, evaluations and pre and post questionnaires of all of the participants including the students, tutors and administrators.

\section{Guiding Research Questions for the Evaluation}

The following questions were created after having meetings with the director of The Lutheran Community Services Somali Pathways Program.

1. Is the Lutheran Community Services Removing Barriers to Self-Sufficiency a successful program? Is it a model to be duplicated?

2. What does successful mean for a language program with participants that are primarily pre-literate?

3. Can Somali women acquire enough English skills to be employable after receiving 72 hours of tutoring from non-professional English as a Second Language tutors?

4. What factors lead to success in studying and acquiring a foreign language for refugee women from Somalia who have no formal schooling or literacy training in their own language?

5. Does the background of the tutor determine the success of a Somali woman learning English? 
6. How should refugee English as a Second Language programs be evaluated?

\section{Method}

This study was a formative one that included collecting data from 28 Somali students, their tutors, and the program staff. The English tests and questionnaire data was collected from the students in their homes. A program staff person was the interpreter for all questions in Somali. The tutors' questionnaires were conducted during program trainings and over the phone. Three pairs of students and tutors were observed in the Somali homes at three separate times during the program.

\section{Definitions}

AFS - Adult and Family Service, the State of Oregon agency that distributes cash and food assistance to families in need.

C.A.L. - The Center for Applied Linguistics.

Cultural Orientation - An orientation the refugees receive from an agency before they go to the United States. The orientations include information about cultural norms, employment, housing, sponsorship and travel to and in the United States.

E.S.L. - English as a Second Language.

Free Case - A refugee case that has no relative living in the United States who can sponsor them. They are sponsored by a church or a refugee agency.

I.O.M. - International Office of Migration, the office that arranges transportation and transportation loans for refugees coming to the United States.

I.N.S. - United States Immigration and Naturalization Service.

Immigrants - People other than refugees who are legally admitted to a country for permanent residence or citizenship. 
J.V.A.R. - The Joint Voluntary Agency Representative is one agency in Africa that aids the refugees in the camps and gives the orientations to the refugees who are accepted to live in other countries.

O.R.R. - United States Government Office of Refugee Resettlement.

Refugees - People who leave their country of origin because of persecution or a wellfounded fear of persecution on the basis of race, religion, nationality, membership in a particular social group, or political affiliation. All refugees coming to the United States must have a sponsor. A sponsor may be a church, an individual, a family member of the refugee, or a refugee resettlement agency. Refugees may apply for citizenship exactly five years after the day they enter the United States.

Refugees in Oregon have come from countries such as: Angola, Bosnia, Burma, Iran, Laos, Sierra Leon, Somalia, The Former Soviet Union, Vietnam.

Voluntary Agency - A non-profit agency that is charged with helping the refugees find initial food, housing, interpretative aid, medical care, and job referrals. In the United States, the voluntary agencies have contracts with the government to help the refugees become self-sufficient in an agreed amount of time. 


\section{CHAPTER TWO}

Literature Review

Refugees are people who are forced to flee from their homeland to another country usually without having the time to prepare in advance to live in another nation, culture and language. When refugees enter the United States, they may or may not come with literacy skills in English or their own language. When the United States decides to accept refugees into its borders, it expects them to become selfsufficient as quickly as possible. The Organization for Economic Co-operation and Development (OECD) states that, "Literacy is a powerful determinant of an individual's life chances and quality of life population"'(OECD, 1997, p.11). Without having literacy skills, it is difficult for refugees to obtain employment in order to achieve a good quality of life in the United States. The government of the United States is concerned with the refugees' quality of life and chances to become literate in English because those factors determine how much financial support from the government the refugee and his or her family will require in the future.

It is easier to become employed in the United States if one can read and write in English. However, there are large groups of people who are invited to come to the United States as refugees who do not possess the skills to speak, read or write in English or their own language. These refugees do not become self-sufficient quickly after their arrival; and after a few months, the government becomes concerned. It is the inability to become "self sufficient" economically that induces the government to support specialty literacy programs for refugees. 
The newly arrived refugees are initially welcomed and supported by private non-profit (usually church-affiliated) agencies that receive contracts from the United States government. These agencies, referred to as refugee resettlement agencies, prepare refugees to begin working as soon as possible after they enter the United States. Usually, this employment training and placement begins within a few weeks of arrival in the United States. However, even after attending the regular English as a Second Language and job-seeking classes, some refugees remain unemployed. They continue to lack the linguistic and cultural skills needed to work effectively in a company in the United States.

The United States Office of Refugee Relations (O.R.R.) funnels financial support to local state governments to fund the programs that aid the refugees acquiring literacy in English. To survive as entities, the refugee agencies are compelled to develop creative and effective programs that attack the problems of the current refugee populations who are encountering difficulties that no one anticipated. By utilizing program evaluations, the ORR and the state offices determine which programs proposed for by non-profit and other governmental offices will be funded and which program ideas are not effective enough to receive any monetary support.

Refugees or involuntary minorities often have the most difficult time learning acquiring literacy skills in a new language. "Such involuntary minorities may develop a sense of social identity in opposition to... a dominant group, resisting behaviors (such as high levels of literacy or participation in advanced education) associated with assimilation into the majority society" (Cumming, 1992, p. 2). Some 
Mayan refugees in Canada found literacy instruction to be irrelevant and even "in violation of their cultural norms for group behavior, or contrary to their social interests" (Cumming, 1992, p. 2.) The Somali refugee women, as did the women in the Athapaskan community in the Yukon, may find resisting literacy a way to hold on to their own cultural and religious values and avoid assimilation into a Christian and European-based culture (Cumming, 1992.) Women's roles and responsibilities to take care of their families can also prevent them from adapting to a new culture and understanding the advantages of becoming literate in the new language.

Evaluation of a program is the key to ensure that future programs will be effective for its constituents. Sometimes the government evaluates the program by examining only the allocation of the grant money during the project. If the money was spent as was written in the grant, and the program seems to run all of its activities on time, the grants are automatically deemed successful. In some cases, the contracts are easily renewed.

\section{Program Evaluation Types}

There are several types of program evaluation. The two basic types are process and outcome-based.(Long, 1994). The evaluation of the Somali Women's Pathway to Remove Barriers Project includes a combination of process and outcomebased evaluation components. This study evaluates a program that attempts to bring 28 Somali Benadir women to an employable level of literacy in English. This chapter examines aspects that affect the evaluation of the Somali Women's Project.

Brown and Pennington in their article (1991) "Developing Effective 
Evaluation Systems for Language Programs," state, "Language program evaluation is not an exact science and requires subjective judgements at many points" (p. 3). Leonard Bickman (1987) comments that because of political concerns surrounding a program, objectives and underlying theory may be left ambiguous. Bickman (1987) also states that program evaluation has developed from simply examining the input/output to examining what is occurring inside the program itself to understand the program.

In "Process and Product in ESL Program Evaluation," Long (1984) states that most evaluations now are product oriented. Product-oriented evaluations are based on the use of final test results or tangible creations made during a program. The measured results of these creations determine the success of the program. For example, if a group of refugees was supposed to learn the alphabet used in the English language, the success of the programs would be based only on numbers of refugees who learned the twenty-six letters of the alphabet. This type of product evaluation would not examine how the refugees reached those results.

Product evaluations ignore possible explanations and the processes that lead to the evaluation results (Long, 1983). They record only what the participants have achieved and how the program achieved its goals. In contrast, Barreta argues that evaluation should apply inquiry as well as an examination of results (Barretta, 1986). Inquiry provides a larger picture of exactly what the participants in the program did to achieve their goals. Examining the reasons why the participants did or did not meet the program's objectives can help program directors create better programs in 
the future.

The refugee resettlement field is often presented with new cultures and is faced with the challenge of developing new programs for each refugee group quickly. Each population will succeed to achieve objectives with varying techniques. Without inquiry and examination of these techniques, program creators cannot be certain that the programs they administered are efficient models for each culture that is intended to use it.

\section{Product Evaluation}

Pre and post tests - examining language abilities.

The basis of a product evaluation is the ultimate result of the program. For language programs, the results can be measured by administering content and skills tests before the program begins and by giving tests after the program is finished. A pre-test is given to the participants before the program begins. The results of the pretest give the program administrators some idea of the knowledge level of the participators; the pre-test can be a guide of what the program expects them to learn. The instruments used for testing may affect the results. The post-test is administered after the program is declared finished. The pre-test and post-test should have the same level of difficulty. The time allotted for each test should be the same.

There are several proficiency tests that are commercially available to use. A proficiency test measures the amount of language the student learned "without reference to a particular program or its objectives and materials" (Brown and Pennington, 1991, p.7). The Basic English Skills Test (B.E.S.T.) 
(1982) and the Comprehensive Adult Student Assessment System

(C.A.S.A.S. E.S.L. Appraisal) (1990) are two of the most popular assessment tools used currently by adult E.S.L. programs.

The B.E.S.T. test was created by the Center for Applied Linguistics (CAL) to assess the language skills of Southeast Asian refugees. The test includes questions that determine literacy and speaking and listening skills. It is necessary for the tester to be trained to administer this test. The tester can administer only one participant test at a time. The B.E.S.T. tests the lowest level literacy and verbal skills (Burt \& Keenan, 1995). The C.A.S.A.S. E.S.L. (1990) is a multiple-choice test that assesses reading and listening. It is given to groups of prospective students. It does not test individual speaking skills at all.

Other available tests include the Basic Inventory of Natural Language (B.I.N.L.), the Henderson-Moriaty E.S.L. Placement (H.E.L.P) (1990), and the Volunteers of America's E.S.L. Oral Assessment (E.S.L.O.A.) (1993). The B.I.N.L. tests the grammatical skills of the spoken language of the student. The H.E.L.P. measures the literacy skills of Southeast Asian refugees in their native language as well as in English. The E.S.L.O.A. tests speaking and listening skills.

None of these tests examines the goals of the learners (Burt \& Keenan, 1995). Alternative testing methods such as surveys, interviews, 
learner self-assessment, and checklists may be used to discover the aspirations of the student.

For exiting tests, programs may choose to administer performancebased tests that assess if a learner can succeed at completing tasks that are presented in context. Authentic materials and realistic tasks involving language may be utilized during this type of examination. Burt \& Keenan state that many E.S.L. programs chose to use alternative tools as well as commercially prepared tests because their funding sources require the commercial tests.

Some of the programs developed to train refugees do not help the refugees to succeed in learning new language or employment skills. It is vital that the programs designed for refugees be evaluated and adjusted or cut when necessary. Creating programs for refugees is complicated because the refugees must overcome special cultural, linguistic, emotional, and economic barriers. Since refugees are admitted to the United States because they flee persecution or they fear persecution on the basis of factors such as race, religion, and national origin in their own country, they enter the United States with concerns that affect their ability to process information and learn any language. One example of a cultural barrier that Somali women encounter is that they are expected to attend classes in the United States to learn English. In their culture in Somalia, many of the women were discouraged from attending school because they were expected to become good wives, not 
scholars. Their lack of experience in a formal school setting creates

difficulties for them to learn language in a classroom.

Some major challenges exist for evaluators of refugee language

support programs. If the programs are simply evaluated with product

evaluations, several factors may be missed. There are challenges facing

evaluators including details that cannot be measured by product evaluations.

These factors are:

1. How to effectively test the language achievement of the refugees

2. How to measure the effectiveness of volunteers (due to the agency's necessity of using volunteers because it is not able to pay trained staff to teach the refugees)

3. How to examine the effectiveness of the staff's actions

4. How to determine if the components of the program (such as the organization and materials) are appropriate, and if they are accepted and understood by the refugees and volunteers.

\section{Process Evaluations}

Long (1984) advocates for the development and use of process evaluations. He states that only with process evaluations, can one obtain the reasons why the results of the program occurred. There are two levels to examine. These include the process of the program itself and the process of the progress of the participants.

The examination of the evaluation procedures provides more than just a simple curriculum review. It examines the productivity of the materials that were used. It also examines the time and staff (paid or volunteer) effort needed to make the program succeed. There are various ways to measure program success. One method is to determine if the participants achieved the objectives set for them. However, Long argues that even if the participants achieved success in passing the post-test, it 
does not necessarily mean the program was effective. Some connection between the program and the progress should be shown. Factors outside of the program could affect the outcome.

Some of the factors that affect the results of a program can be discovered through the process evaluation of the participants themselves. This evaluation can be done by reviewing comments from surveys or interviews held before, during and after the program. In the case of the Somali program, these comments can come directly from the Somali women, the program administrators or others involved in aiding the participants. Continually asking for the participants' comments in the area also aids the agency to create an effective progressive picture of the participants' experience. To understand the experience of the program participants who drop out of a program before the final post-test is administered, the process type evaluation provides some clues about what their experiences were and why the participants left.

The progress of the advancement of the participants will vary according to culture and educational background (Burt \& Keenan, 1995). When testing refugees who do not have experience taking oral or written tests in a school setting such as the women participants of The Somali Women's Pathway to Self-Sufficiency Program, the process of testing must be considered. The Somali women's inexperience with formal western-style testing could influence the final numeric results. As they are testing at different points during the program, they will become more familiar and comfortable with testing procedures. The fact that success is observed in the testing results may be due to the familiarity with taking tests. 
Having pre and post skill tests is not the only method to evaluate a program or the success of the participants. In fact, many instructors have found that commercially distributed testing tools are not satisfactory for determining program success (Burt \& Keenan, 1995). There are several ways to measure the effectiveness of a program that do not include prefabricated tests. For example, for family literacy programs, if the parents read more to their children or have more books at their homes after participating in the program, the program could be deemed successful. In the case of the Somali women, having more literature in English present in the homes may signify that the women achieved literacy skills or that they were interested in practicing the language skills they learned. For other programs, a marked increase in self-esteem and more participation in outside social community activities could indicate that the program was effective (Burt \& Keenan, 1995). The growth of self-esteem is important for refugee programs created for women. With increased self-esteem, the refugees feel more comfortable practicing their new language skills and making mistakes using the new language. Refugees can acquire more language skills at faster rate if they are willing to make mistakes while speaking the new language. Self-esteem is easily lost when one is taken from their familiar home, job and family and plunged into a life, language and economic level that they never had dreamed of facing and never prepared for the situation in any way. 
Affective factors in process evaluation.

When administering a process evaluation there are many factors that must be considered. Affective, also known as emotional factors, can impact foreign language learning and testing results. Affective factors include motivation and attitudes. "We posit a psychological construct, a 'filter' of some kind, which rises/stands in the way of incoming language data. The term, 'socio-affective filter', 'affective filter', or simply 'filter' was first used by Dulay and Burt (1977) was included in Krashen's theories (Krashen, 1982), and has been used widely in professional discussions in the 1980 's" (Laine, 1989, p.1). The filter can cause a person who is very capable of learning a second language to have such extreme perceived difficulties that she is no longer able to acquire the language.

Self-concept is an integral part of the affective filter. Self-concept is how one person sees herself as she experiences herself. It includes the way a person acts, how she feels, what she believes and how she evaluates herself (Laine, 1994). The way a person behaves in a situation is determined by her self-concept. When a person has a weak self-concept, many defenses and inhibitions appear (Laine, 1989). Laine explains that self-concept can be considered on three levels: general global, specific, and task. It is the general global level includes the environment and family situations that can affect a language learner. 
In Language Testing in the 1990's, Alderson (1991) states that one must be aware of the affective factors while designing tests. Some of the affective factors in testing are predictable. In the case of the Somali women, there are affective factors. One of the cultural factors for the Somali women includes not accepting a male interviewer in their homes. Other affective factors that can influence the evaluation are the location of the interview and the interviewer's age, speech patterns (British vs. North American), and marital status.

\section{Process evaluation observations.}

Observations are used in evaluating linguistic and social behavior during a program's instruction. In an observation, the researcher watches the interactions between the students and the teachers. The researcher may take notes of general behavior or interactions or she/he may use a checklist or a list of certain inventories. If only one learner is observed, the notes of the observer can be utilized to create a case study (Brown and Pennington, 1991.)

Process evaluation questionnaires.

To prepare an effective questionnaire, Miller (1994) suggests creating a steering committee and using the suggestions of the program administrators when constructing a survey for an evaluation. Each question should be "judged against the purposes for which the survey is to be conducted and the uses for the information it will generate" (Miller, 1994, p. 282). 
Process evaluation interviews.

Interviews can lead to discovering the true opinions of the

participants. Open-ended questions and confidentiality can provide insights

that otherwise might have been missed by using only a questionnaire.

"Because interviews are time-consuming, they are often not used in

evaluations" (Brown and Pennington, 1991, p.9).

Alternative methods to measure outcomes.

To ensure that the students are involved in their own assessment, real life tasks that mirror competency tests should be part of the exams (Crandall, 1992). A formative program evaluation could be enhanced by including activities such as adult reading and writing inventories, journals, peer interviews, competency checklists, and self-assessments (Crandall, 1992).

Styles of program evaluations of adult literacy programs as well as the programs themselves are constantly changing. There is no single type of evaluation used by the Office of Refugee Resettlement (ORR) for the various literacy programs that they fund. The assessment and evaluation of adult programs usually depend on what administrators and financial supporters want (Crandall, 1992). Effective evaluations are possible when a series of factors are considered. Crandall lists the nine necessary features of an effective adult literacy program evaluation identified by Lytle and Wolfe. These include:

Requiring both external and internal evaluation; Collecting formative and summative evaluation; Involving learners and staff in a participatory process; Giving prominence to learning and teaching; 
Capturing a range of learner and program outcomes; Employing a variety of methods over time;

Being based on theory and research, as well as in practice; Involving critical reflection on program philosophy and goals; Being integrated with program functions and being systematic and systemic (Crandall, 1992, p. 90).

Crandall states that these features are important but that adult literacy programs may not implement them all because the programs are usually constrained by small budgets.

Crandall explains that funders and administrators want quantifiable data while teachers and students want to see more qualitative tests. The problem to be addressed in the Pathways Program is how Somali women (many preliterate) who were unable to learn English (spoken and written) in the regular classes provided by the State of Oregon can reach employable levels of English. The persons served are 28 unemployed Somali women who entered the United States by 1997.

The Components of the Somali Pathways Project

When creating an evaluation of a specific program, the six basic items should be considered are:

1. The problem addressed

2. The persons served

3. The services provided

4. The evaluation context

5. The expected outcomes

6. The justification or rationale. (Schalock and Thornton, 1988, p.24)

The Problem Addressed

The problem that the evaluation of The Somali Woman's Pathway To SelfSufficiency Project is attacking is the low-literacy acquisition rate of Somali 
women in Portland, Oregon.

The Somali Refugee Woman's Pathway to Self-Sufficiency Project: Removing Barriers is a program created by Lutheran Family Service, a nonprofit refugee resettlement agency in Portland, Oregon. The goal of the project is to "continue providing and developing services for Somali women refugees who, after a year in the U.S., continue to have difficulties adjusting to the demands of American life" (The Somali Refugee Women's Pathway to Self Sufficiency Project: Removing Barriers Final Proposal, 1999, p.1). The services that are provided are intended to increase Somali women's literacy and English language skills, help develop parenting skills to bring them selfsufficiency. The programs goals include referring some of the women to an employment agency.

In a report about world literacy statistics produced by the OECD (The Organization for Economic Co-operation and Development) in 1997, the OCED declared that there is a "considerable loss in earnings associated with a lack of language proficiency among immigrants and the general population" (OECD, 1997, p.43). Lutheran Community Services discovered that most of the Somali women had not gained significant language skills in English after attending classes provided to them by the State of Oregon and Adult and Family Service (AFS). The staff at Lutheran Family Service and welfare recognized that the women were not prepared to gain employment. 
Having jobs would allow them to earn sufficient wages and support their family without much or any governmental assistance.

The idea for the Somali women's project came to a Lutheran Family Services' staff member after she interviewed one of the AFS teachers who had worked with the Somali women for an extended period of time. The Lutheran Family staff member and the AFS teacher decided that the Somali women were in dire need of literacy skills but that the current language programs were not meeting the needs of the Somali population. Furthermore, attempting to instruct writing skills to the women in a group setting was not productive. "There is some evidence that reading and writing literacy are more important than speaking literacy in studies concerning the United States" (OECD, 1997, p.64). Lutheran Community Services surmised that the Somali women needed to become literate so that they could eventually become self-sufficient. The women would acquire other benefits from becoming literate, also. According to OECD studies, literacy brings "a better quality of life in terms of...improved health and child-rearing...And there are other contributions...such as political participation, and broad adjustment to technological change" (OECD, 1997, p.57).

Lutheran Family Services conducted a survey of the Somali women in need in the fall of 1998. After examining the results of this survey, they determined that the Somali women needed literacy, parenting and employment assistance. 
The percentage of the women who had received formal education for an extended period of time in the past was extremely low. Nineteen Somali female refugees living in Portland, Oregon, responded to the survey; $26 \%$ (5 women) indicated that they had had no education in Somalia or in the United States, $31 \%$ (6 women) had less than eight years of education, $32 \%(6$ women) had some high school education and 11\% ( 2 women) finished high school (The Somali Refugee Women's Pathway to Self Sufficiency Project: Removing Barriers Final Proposal, 1999, p.2). Thus, Lutheran Family Services concluded that the best program would be one-on-one tutoring in English for the women because the women with no or little educational background were not ready to learn English in a classroom without individual assistance.

The agency planned to give each refugee 72 hours of individual tutoring so that each woman could gain the necessary literacy skills and confidence to join an English class or work in various situations.

The persons served - Somali female participants of the Pathway Program.

The aspects of the women's backgrounds as refugees that are considered when creating the Somali Women's Program evaluation include the general political and education situation for women in Somalia, the barriers they encounter when trying to learn English in the United States and the family situation and how that affects literacy acquisition. 


\section{Cultural information about the Benadir.}

The Benadir come from an area in Somalia that is between $8^{\prime}$ and $12^{\prime}$ North latitude and between $42^{\prime}$ and $16^{\prime}$ East (Battandier, 1907). The first communities of Benadir were created in Somalia over one thousand years ago. Benadir have been known to be good business people and who were known as peace-loving since the $13^{\text {th }}$ century when travelers first recorded information about them (Somali-Benadir Benadiri Center, 2000).

The northeast coast of Africa was known as the Benadir Coast until the $20^{\text {th }}$ century. The Benadir people were people who originally came from Ancient Arabia, Persia and south and central Asia. The name "Benadir" came from the Persian or Italian word ("el banadir" - "the ports") for harbor or port. Many of the Benadir are different from other Africans because they tend to have lighter skin than other Africans. The ancient Benadir city of Hmar, a port, became Mogadishu, the modern capital of Somalia. Many of the Benadir were merchants and owned stone houses. The other clans in Somalia were primarily nomadic (Refugee Resource Center Somalis Refugee Factsheet \#9, 2000). 


\section{Map of Somalia}

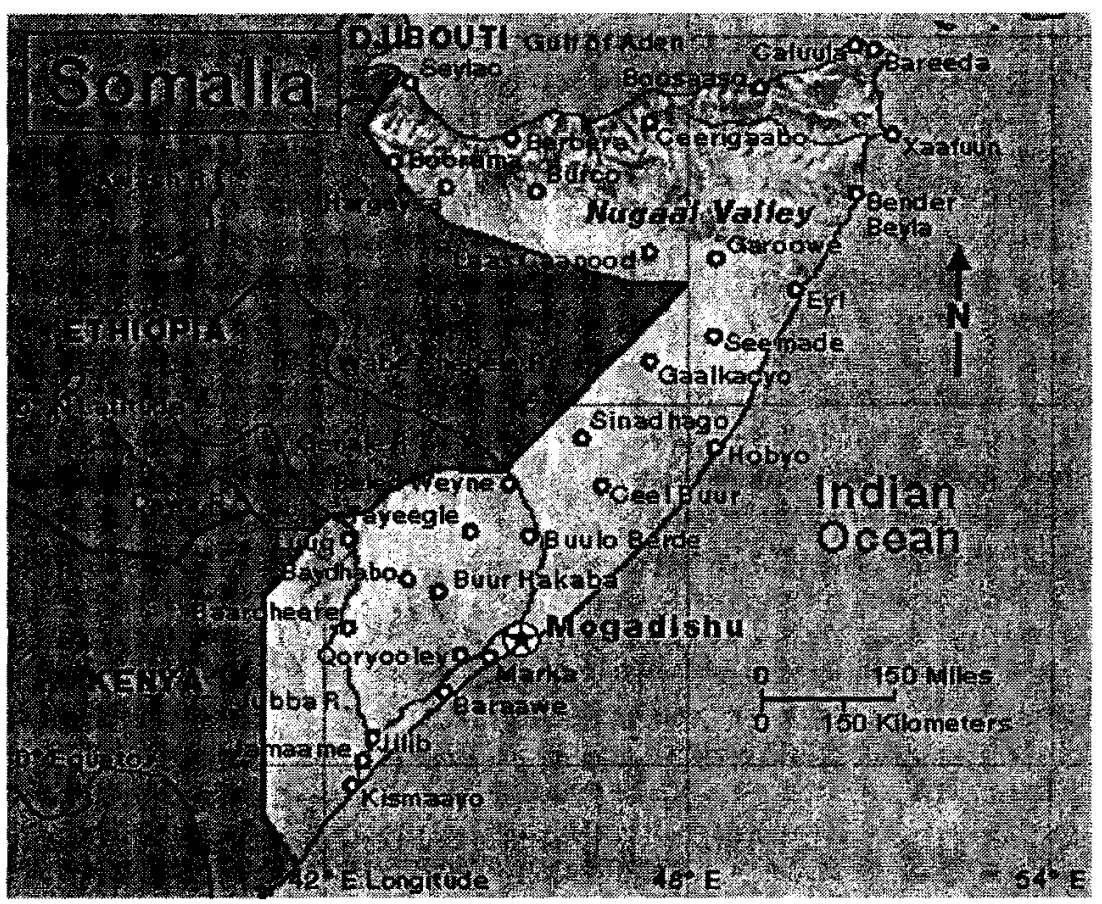

zoom out

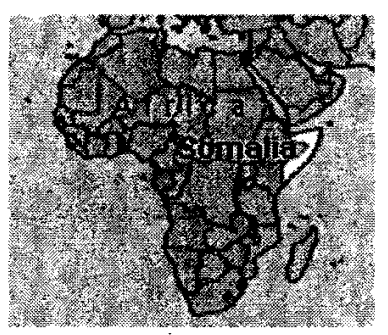

Figure 1 Map of Somalia

World Book Map; map data (c) MapQuest.com, Inc., retrieved from

http:/school.discovery.com/homeworkhelp/worldbook/atozpictures/mp000209.html,

In the 1800 's, Somalia was ruled by the British in the north and by the

Italians in the south. After World War II, Britain and Italy did not have such

strict control of Somalia. With the support of the United Nations, the two 
former colonies of Somalia, north and south, were united to form the Somali Democratic Republic (Refugee Resource Center Somalis Refugee Factsheet $\# 9,2000)$.

During the Somali's struggle to become an independent nation, many women contributed to the cause by selling their jewelry to support the fighting, participating in demonstrations, and hiding freedom fighters in their homes. The colonial governments jailed some of the women for their actions. When the Somali people gained their independence from Britain and Italy on July 1, 1960, women were not allowed to be part of the newly formed government.

In 1969, Siyad Barre and his clan took power of Somalia through a coup d'etat. And in the 1970s, Somalia battled with Ethiopia over territory that Somalia claimed as its own. The clans also fought each other and this caused a war (Refugee Resource Center Somalis Refugee Factsheet \#9, 2000).

\section{Clan and community.}

The life of the Benadir is based on their clan relations. It is said that each clan can trace itself to a single male ancestor. The clans who came to the US include the Shanshi, Asharaf, Bandhabow, DhabarWeyne, Faqi, Morshe, and Rer Manyo (Biber \& Hared, 1991). The last name of a person usually indicates their clan affiliation. Somalis have three names. The first name is a given name (commonly determined by rank of birth or other distinguishable 
traits), the second name is their father's name, and the third is their grandfather's name. Women do not alter their names when they get married. Many of the names are based on Islamic traditions and texts.

The clan elders, who are exclusively male, decide the outcomes of the problems in the community. They make rulings about family problems, inheritances and other municipal matters. The elders continue to have influence over Somali refugees who have ended up in the United States. The elders from all of the states come together to meet in Washington D.C. for an annual meeting.

Clan tensions impeded the creation of a formal Somali organization in Portland, Oregon. About one year after most of the Benadir had arrived in Oregon, some of the men visited three of the refugee resettlement agencies and the International Refugee Center of Oregon (IRCO) to ask for assistance to create a formal Somali organization in Oregon. A few meetings were held but because the representatives from IRCO, the main supporting agency, belonged to Somali clans distrusted by the Benadir and other Somali clans represented in Oregon, the organization never came to fruition. The staff at the Lutheran Family Service hopes that the Benadir women will form their own local organization. The Lutheran Family Services is willing to support this effort.

In public, the Somali society is male centered (Refugee Resource Center Somalis Refugee Factsheet \#9, 2000). Most of the Somali men who 
came to the United States are very well educated and are able to speak a number of languages including Arabic, English, Italian and Russian. Most of the women were not allowed to finish high school. Many married when they were fifteen or sixteen and started to take full responsibility for household duties at that time.

Somali women, clothing and U.S. culture.

The older female refugees who came to the United States prefer to wear their Somali traditional dress. A Somali staff person at Lutheran Family Service explains that the Somali women do not want to lose ties with their customs from Somalia. They feel that if the women begin to wear western clothing, they may begin to pick up traits and western attitudes. Not wearing western dress can cause a conflict when the women need to work in United States. Some jobs require uniforms.

When they first arrived, some men did not allow the women in their family to wear pants. This caused problems in the workplace because sometimes part of the required uniform was pants. Some female Somali workers also had trouble in the workplace because they always wear something on their heads because of Islamic tradition.

Somali women and human rights.

Barre's government attempted to help the Somali women's situation but that aid was met with great hostility by the men and especially the religious men who said the Qu'ran outlined submission of women. 
Somali women have the right to vote in Somalia but they are not allowed to participate in the tribal or assembly of elders where the real decision making for the members of the clan takes place.

According to Africa Watch, one half of the women reported to have been tortured, raped, and killed because of their clan, Amnesty International state that rapes in Somalia occurred "massive in scale" (Africa Watch, 2000). These women were ostracized because others saw rape as something the women caused.

Somali women and religion.

According to Islam, men may have more than one wife. Refugees coming to the United States are not allowed to practice polygamy. This caused some of the male refugees to leave some wives and children in Somalia. Some of the Somali women agreed to take some children with them to the United States as refugees even if children were not their own. Journey as Refugees to the United States

Participants of the Pathways Program are women who came from Somalia as refugees to the United States from 1996-1999. The official United Nations definition of a "refugee is a person who "is forced to leave their country of origin because of persecution or a well-founded fear of persecution on the basis of race, religion, nationality, membership in a particular social group or political affiliation" (Questions and Answers about The United States Refugee Resettlement Program, 2000). The Benadir Clan 
was a particular social group that was persecuted in Somalia for not taking sides during the civil war. "The clan members, frequent targets of battling war lords because of their relative wealth and their unwillingness to arm themselves, fled several years ago from Mogadishu to refugee camps in Kenya, Yemen and Ethiopia" (The Oregonian, 1996, p.CO2).

In 1991, there was strong fighting in Mogadishu. The Benadir were attacked. They were unarmed and they became the victims to all of the different fighting factions. Their houses and businesses were destroyed and soldiers raped many of the women. All of their material wealth was taken forcibly from them.

About ten thousand Benadir were able to leave Mogadishu. Many fled to Kismayo, Kenya by boat or overland and then they went to Kenya to wait in refugee camps. The condition of the camps was extremely difficult for the wealthy Benadir to handle. Whole families lived in one tent with a dirt floor. The women tried to protect their children and grow some food because the rations given to them were small. Malaria spread rapidly among the refugees. Rapes were common and the women had to be especially careful even going to the bathroom in the evening. Kenya did not have enough money to support refugees. By 1994, most of the Benadir had moved out of Somalia.

In 1996, a group of more than four thousand refugees from the Benadir Clan from Somalia were accepted by the United States government to resettle in the United States. The people who claim that they are members 
of the Benadir Clan are people who lived in the Mogadishu area of Somalia, the capital of the country. The Benadirs are the traditional salespeople and businessmen. They are different than the other clans because they are not nomadic and they do not depend on raising animals and farm work for their livelihood.

The families fled from Somalia and ended up residing in refugee camps from four to six years in Kenya. When the Benadir refugees left Somalia, they had not planned on leaving Africa.

In the camps, the families had little hope in the camps and tried to adjust to living on dirt floors in tents made of blankets. It was a struggle to survive. Up until that point, the Benadir women had no plans to come to the United States and most of them did not have the chance to study any English. In the camps, unlike in the camps for the Southeast Asian refugees in the 1970 's, there were no schools or educational programs for the Benadir men, women or children.

In early 1996, The International Organization for Migration (IOM) and the Joint Voluntary Agencies (JVA's) began to give the Benadir cultural information classes sessions. There were three types of classes. Some Somali refugees received a 10-day session (45 hours), a 3-day session (16 hours) or a 1-day (4-8 hours) cultural orientation. Unlike the Southeast Asian refugees in the 1970's who had several months of English as Second Language training in the refugee camps before coming the United States, most Somali 
refugees received no English language instruction. In Kenya in the 1990's there was no money allocated for any formal education in the refugee camps.

The Benadir were resettled all over the United States. When the group of just over 200 Benadir arrived in Portland, Oregon, very few female of the Benadir refugees spoke English. Some of the Benadir men had worked with international companies in Somalia and could speak English as well as Arabic, Italian and Russian.

Since the refugees from Somalia are a relatively new population to the United States, published literature concerning their specific abilities or difficulties in learning to speak and write in English or cultural problems are hard to find.

\section{Language and Literacy in Somalia}

Somali, the language that most of the program participants speak, is a Cushitic language that is spoken in Somalia, Kenya, Ethiopia and Djibouti (Biber \& Hared, 1992). Benadiri, the language of the Benadir Clan, is a dialect of Somali.

The Benadir Clan's language includes many Arabic words. They usually also speak another foreign language such as Arabic, Italian or English. Cushitic languages have the clause pattern of first the subject, then the object followed by the verb whereas in English, the clauses are usually created with the subject first, object second and verb last (Comrie, 1989). All of the adjectives, genitives and relative clauses come before the main noun. 
Until recently, there was no written form of the Somali language.

Somali President Siyaad Barre introduced the new Somali standardized written form based on the Roman alphabet in 1972. Before that, Arabic, Italian and English were used as the official languages for government and commerce. Literacy campaigns attempted to educate the people how to read and write in the new form. However, this was difficult (Refugee Resource Center Somalis Refugee Factsheet \#9, 2000). In 1980, over seventy percent of the Somali population that was fifteen years-old or older was illiterate (Bhatia, 1983). By 1990, the United Nations reported that about only 24 percent of the Somalis were literate. Despite the literacy campaigns, 96 percent of Somali women cannot read Somali. Girls received one-third the education of that boys did (Refugee Resource Center Somalis Refugee Factsheet $\# 9,2000$ ).

From $1972-1975$, the government implemented literacy campaigns to teach the population how to write. The literacy teachers were people who had completed the last two years of elementary school and the first two years of high school (Biber \& Hared, 1992). The language planners who developed the orthography attempted to make it adaptable to modern needs. There is little stigma attached to illiteracy when not all of the community is expected to be literate.

\section{Somali pronunciation.}

Somali uses every letter included in the English alphabet except for $p$, $v$, and $z$. Fifteen sounds of the language that are very similar to the English 
sounds are $b, d, f, g, h, k, l, m, n, s, s h, t, w$, and y (Refugee Resource Center Somalis Refugee Factsheet \#9, 2000.) The consonants that do not match English are c, dh, q, r, $x$ and '(a glottal stop.) These are the sounds that cause the most trouble for Somali speakers when they attempt to speak English. Services Provided - Literacy Instruction Models

Literature about services based on group instruction programs is available; however, the articles detailing a small-scale one-on-one tutoring program (fewer than 100 participants) are difficult to locate.

Puchner (1977) explains that the model of an individual tutor with one student is a model that comes directly from mainstream North American culture. Literacy program coordinators may not consider the entire cultural context for the students and they may be transplanting their own norms on the students. There are certain cultural assumptions from a Euro-American approach that are inherent in these types of models (Puchner, 1997).

For the women who are referred to employment assistance programs, certain skills are needed. These skills include effective decision-making, problem solving, planning, creative thinking and listening (Florez, 1998).

The program has an E.S.L. Coordinator who will devise an individualized study plan for each client with her tutor. This plan will be based on the initial literacy and speaking test that the participants complete. The tutors submit a monthly progress report to the E.S.L. Coordinator. The plan is revised as the tutor and E.S.L. Coordinator determine necessary, 
The Evaluation Context - Motivation to Learn English

One assumption is that providing literacy training is always good. Puchner (1977) indicate that "What this assumption fails to recognize is that becoming literate in a certain language in a certain context may have a significant impact on community and family, sometimes contributing to changes in and even a breakdown of the stability of these structures" (Puchner, 1977, p.7).

When the children in the family obtain stronger speaking and writing skills in English than what their parents have, the power in the family shifts. The children become the translators and interpreters for the parents. The parents rely on them so much that a role reversal may occur. The parents may loose authority over the children. School systems have learned not to rely on children for interpreting services because there have been enough examples of the children telling the parents what they want the parents to hear and not the truth.

One reason adults may want to learn English is so that they can communicate better with their children (Puchner, 1997). Without English, the parents cannot help their children with their homework.

Sometimes children try to maintain that powerful position. One child told his mother that she was too old to learn English and that she should not even try (Puchner, 1997). Another type of power struggle may occur when the parent does not want their children to have full command of their first 
language. Thus the parents can remain competent in one area where their children are struggling. One type of situation that is common is that when the adult addresses the child in their native language, the children answer in English. The strict gender rules that were applied in the home country may be altered to fit the North American style of life.

According to Puchner (1977) when a group of immigrants was asked why they wanted to learn English, none of them mentioned survival skills (Puchner, 1977). They were already surviving and they really wanted to learn English so they could communicate with their children and grandchildren.

Puchner summarizes the need for programs to address research. She states, "A final implication of a cultural view of family literacy is that research needs to be built into literacy programs. Family literacy initiatives in any community should begin with focus groups or other ways of talking to people to find out exactly what types of approaches would most directly address the needs of those concerned" (Puchner, 1997, p.5).

Evaluations of refugee programs can become extremely complicated because there are several factors to consider when assessing a refugee program. The most effective evaluations are based on evaluation theory with consideration of the cultural and background factors of the certain populations to be studied. Each population comes to the United States with its cultural values which ultimately determine who can and will be educated. Evaluations also determine who will receive support to study language. 
There are many factors to consider when evaluating English as a

Second Language programs for adults (i.e. tutoring programs.) Validity of the testing is a major concern.

Validity of English Language Testing

There are many factors that affect validity of the language testing.

One factor that the Lutheran Family staff that worked with Somali women noted is the relationships the participants make with native English speakers outside of the program. The participants may start to befriend Americans other than their tutors because they have some experience making friendships. This would affect their language achievement and create higher scores than if they only relied on a person they considered only as their tutor for assistance. Their attitudes toward the English language could improve and thus they will want to learn more and achieve higher results.

\section{Volunteers in Language Programs}

When a language program is staffed by volunteers, several potential problems may arise. A participant may not like her volunteer teacher and refuse to continue the program. This could be hazardous to the results of the language pre and post-tests. In addition, the findings of a study using volunteer teachers cannot be applied to non-volunteer teachers (Baretta, 1986). Long states that any of the aforementioned concerns could affect the results of any evaluation. He adds that if something occurs during the testing, it is possible to attempt to change the situation (Long, 1986). 
Checking external validity may not be possible when only one population is studied. For the study of the Somali women, there is not enough representation to allow generalization of the results (Barretta, 1986). Another problem could be the fact that the women studied in this evaluation are not randomly assigned to a group. Acquiring Literacy Skills

Acquiring literacy skills is a multi-faceted process. The topic of adult literacy is a broad subject. For this research, I have decided to limit my discussion to letter identification and acquiring basic reading skills. Reading is communication; it is not merely deciphering what is written on a page (Kindell, 1994). Reading is an interactive activity that is one part of learning. Writing is also an interactive activity.

People are able to utilize spoken language when they are faced with a context of real people and situations. Words that are found in written language occur in a different context. To acquire literacy skills, a person must be able to change the context from an oral situation to a written form. (Kindell, 1994). She must also be able to understand at some level that language is divided into sounds, words and sentences.

There are several theories about the best methods for instructing reading. Davis states that literacy instruction should be developed on the basis of the learner's language functions with goals of four language modes (reading writing, speaking and listening.) When a student begins to write, she 
should write sentences that are familiar to her and that are not too formal (Kindell, 1994).

Stienberg encourages tutors or teachers to emphasize only what is meaningful for the learner or what is needed only for the immediate task. There are many suggestions on how to teach reading. Steinberg states that one should begin with word familiarization, and then word identification before moving on to phrases and sentences (Kindell, 1984).

Researches agree that phonological processes are very important to developing reading (Stanovich, 1992). The learner must be able to recognize different phonemes (Kindell, 1984). Caligiri recommends beginning with recognizing first the sounds, then words and phrases. Burke and Woodward recommend that the materials should be concrete and based on what the reader has seen before. They state that readers should not be forced to try to read abstractions such as only letters of words on the page (Kindell, 1984). Cook-Gumperz and Gumperz suggest that familiar oral traditions should be used when instructing a learner how to write.

There are a few considerations about learning the printed form of the letters in English. There are uppercase letters as well as lowercase letters. Capital and small printed letters can appear to be different. When a person writes a letter, there are several different forms that the letter can take. Also, in English, there are forty phonemic units or forty variations that create sounds. Out of the forty phonemes, several of them represent the same 
sounds. For example, the graphemes, "igh" and "eye" are spelled differently but they have the same sound.

To confuse the new writer in English, there are more than 2,000 graphemes. Downing elaborates by stating there is no "easily perceived logic" which a learner can use to write words (Downing, 1973).

At any rate, one thing is quite clear from these investigations: the writing system is an important variable in the learning-to-read process. "A perceived mismatch between the writing system and the language in which the...(learner)...is expected to respond is an important cause of difficulty in the early stages of learning to read and write" (Downing, 1973, p. 154).

Language Outcomes as Outlined in Oregon - State of Oregon English as a Second Language Literacy Competencies

Because educators were concerned that the adult programs were not meeting the needs of the refugee population in Oregon in the 1990's, a committee of English as a Second Language educators in the State of Oregon identified seven minimal competencies in literacy training of learners of English as a Second Language. There are seven main competencies. The first is "Pre-Reading," which includes the ability to understand the reading concepts of same and different. To demonstrate this type of understanding, the learner matches two pictures, which are the same orally or with actions, points to two things with the same color, shape and size, and identifies which object is different than the others. Familiarity with left to right progression is tested by having the learner point to the picture of a story as it is told, put 
three pictures in order and mark a symbol of the left hand of the page. Another related skill is putting a picture story in order from top to bottom.

Identifying numbers is the second competency topic. The learner will count orally from $0-10$ using objects or pictures, point to a number as it is said by the test administrator, put pictures with numbers on them in the correct order, and sequence numbers from 1-10. The learner will read numbers as numerals, read her own telephone number or other personal number and tell the administrator the personal number without looking at it. The learner will also copy numbers and write them as they are dictated to her.

The third topic is letter identification. The learner will say the letter when she is shown it and identify that letter as a small or capital letter. The learner will read and spell names and produce this information from memory. The learner will copy letters and write them down as they are dictated.

The next three competencies listed are tested by the BEST Test. The BEST Test is used in evaluating the Lutheran Family Service literacy program for Somali women.

Identifying common survival symbols is also a competency. The learner shows that she understands common symbols related to health, survival and economic topics. The learner will say the correct name of a sign when it is shown. One example of a symbol is the common picture sign for a restroom. 
The learner will also read basic sight words, including a telephone number, an apartment number, walk and exit. The learner will also read first name, last name, city and state. She will read her own name and address. She will correctly circle the words male or female. Days of the week, months and their abbreviations are also tested. The learner will show that she can read her bus number and symbol.

The learner will demonstrate knowledge in completing forms. The learner will copy words from that board to paper. The learner will write personal information such as her first and last names, address, telephone number and social security number on a piece of paper and on a form. The learner will complete a change-of address from the post office.

The competencies cover the combination of spoken language with the written form. The learner will associate the spoken form with a written sentence. The learner can repeat familiar sentences as she looks at them. She can also put sentence strips in correct order and read the sentences aloud.

The learner will show that she can associate the correct sounds with a letter. The learner will point at the first letter of a word that is given orally. The learner will write this letter. The learner can read a word with the following combination: consonant, vowel and consonant. The learner can point to a familiar word by using the first consonant as a clue (Haverson, 1982). 
The Expected Outcomes

While some outcomes such as language test scores are easy to detect, some outcomes are difficult to measure. According to Affholter (1994), it is easier to "measure program inputs, processes and outputs than to measure program outcomes" (Affholter, 1994, p.107). Affholter suggests being open to see the results of the evaluation and to be careful about being too invested in certain outcomes. "Certain key stakeholders will jump to conclusions based on outcome monitoring reports, conclusions that may be wrong or unfair" (Affholter, 1994, p. 107). Program organizers and participants have their own expected outcomes. The staff who worked on the Somali project at Lutheran Community Services created the program so that the women would become more comfortable and familiar with the culture of the United States while learning basic literacy skills in English. The State of Oregon expected that several of the Somali women would be referred to employment programs by the end of the program.

The Justification or Rationale

There are many challenges to evaluating a literacy program. When the program involves refugees, cultural and educational background must be considered. The evaluation of The Somali Refugee Woman's Pathway to Self-Sufficiency Project: Removing Barriers Project is a formative effort that attempts to create an effective evaluation while considering those factors by analyzing information received through interviews, surveys, formal language testing (oral and written) and observations. 
With effective program evaluation, it is possible to pinpoint the elements of programs that promote quick and effective literacy in English for refugees and to promote them for future programs. 


\section{CHAPTER THREE}

\section{Research Methods}

This chapter will discuss the methodology used in this evaluation research project including instruments of language testing, surveys (pre, midterm and post) of the Somali women and the North American tutors, and the procedures used in collecting and analyzing the data.

The project evaluated 28 Somali women's progress in learning English as they received tutoring from North American female volunteers who came to their homes one to three times on a weekly basis. Lutheran Family Service, a social service agency in Portland Oregon that has a department specializing in refugee programs, organized the program.

\section{Guiding Research Questions}

1. Is the Lutheran Family Services Removing Barriers to Self-Sufficiency Project a successful program? Is it a model to be duplicated?

2. Can Somali women acquire enough English skills to be employable after receiving 72 hours of tutoring from non-professional ESL tutors?

3. What factors lead to success in studying and acquiring foreign language for refugee women from Somalia who have no formal schooling or literacy training in their own language?

4. Does the background of a tutor determine the success of a Somali woman learning English?

5. How should English as a Second Language programs for refugees be evaluated?

$$
\text { General Design of the Study }
$$

This study includes a combination of pre and post achievement testing, interviews, and pre and post surveys. Lutheran Family Services 
arranged to have each Somali woman receive 72 hours of one-on-one tutoring in her home. The investigator suggested that Lutheran Family Service include a type of needs assessment for the Somali women. The investigator created the needs assessment using the suggestions from the Lutheran Family Service staff and literature research to design the needs assessment document. Before the tutoring began, the investigator and an interpreter visited each Somali household and asked each Somali participant to complete a needs assessment, survey and pre-tests (the B.E.S.T. Test, Alphabet Test and Form Test.) Also, before the tutoring began, the investigator surveyed all of the North American tutors. The needs assessments completed by the Somali women at the time of the initial language testing were given to the tutors so that they would know the wishes of their students even if the students could not communicate in English well yet.

Eight of the North American tutors completed a mid-term survey about their teaching experiences. Some of these surveys were conducted over the phone, and some were completed during an informal gathering of tutors and Lutheran Family Service staff.

The final surveys and testing of the Somali women were to be done after all of the women had completed 72 hours of tutoring. In July 2000, the director of the Somali Barriers program announced that the program was officially finished. Only four Somali women completed the total 72-hour program and the 24 women who received less 72 hours of one-on-one 
instruction were tested in their homes at various times in 2000 from January

until September.

Table I. Somali woman's pathways to remove barriers project evaluation timeline

\begin{tabular}{|c|c|}
\hline \multicolumn{2}{|l|}{ Evaluation Timeline } \\
\hline Date & Activity \\
\hline July 1999 & $\begin{array}{l}\text { Lutheran Family Service Pathway's Director and } \\
\text { Investigator evaluation for the project. }\end{array}$ \\
\hline August 1999 & Investigator creates The Alphabet and Form Test. \\
\hline August 1999 & $\begin{array}{l}\text { The Alphabet and Form Tests are piloted with } 30 \\
\text { participants at Clark College. }\end{array}$ \\
\hline $\begin{array}{l}\text { September } 1999- \\
\text { October } 1999\end{array}$ & $\begin{array}{l}\text { Investigator and Interpreter visit each Somali home to } \\
\text { complete the Pre-Tests (The B.E.S.T. Test, The Alphabet } \\
\text { Test and the Form Test), Questionnaires, Needs } \\
\text { Assessments and Permission Forms. }\end{array}$ \\
\hline September 1999 & $\begin{array}{l}\text { Investigator has Lutheran Family Service Staff and } \\
\text { Volunteer Tutors complete the Pre-Questionnaire and } \\
\text { Permission Forms. }\end{array}$ \\
\hline September 1999 & $\begin{array}{l}\text { Each Volunteer Tutor receives the Needs Assessment for } \\
\text { her student. }\end{array}$ \\
\hline December 1999 & $\begin{array}{l}\text { One of the tutors hosts a mid-term potluck with other } \\
\text { tutors and Lutheran Family Service Staff. }\end{array}$ \\
\hline December 1999 & $\begin{array}{l}\text { A staff member of Adult and Family Services has an } \\
\text { open-house to support the Pathways Program by raising } \\
\text { money for instructional books for the Somali women. }\end{array}$ \\
\hline January 2000 & $\begin{array}{l}\text { Some tutors complete a Mid-Term Questionnaire at the } \\
\text { potluck and others answer the questions over the phone. }\end{array}$ \\
\hline February 2000 & $\begin{array}{l}\text { First student completes } 72 \text { hours of tutoring. The } \\
\text { student completes the B.E.S.T. B Test, Alphabet } \\
\text { and Form Test and Final Questionnaire. }\end{array}$ \\
\hline February 2000 & $\begin{array}{l}\text { The tutor of the first student completes the Final } \\
\text { Questionnaire. }\end{array}$ \\
\hline $\begin{array}{l}\text { March } 2000- \\
\text { September } 2000\end{array}$ & $\begin{array}{l}\text { Other students complete } 72 \text { hours of tutoring } \\
\text { The other students complete the B.E.S.T. B Test, } \\
\text { Alphabet and Form Test and Final Questionnaire. }\end{array}$ \\
\hline August 2000 & $\begin{array}{l}\text { Lutheran Family Service Staff invites all tutors } \\
\text { and Somali women to a final picnic celebration. } \\
\text { About one-third participated. }\end{array}$ \\
\hline September 2000 & $\begin{array}{l}\text { Students who do not complete } 72 \text { hours of tutoring } \\
\text { complete the B.E.S.T. B Test, Alphabet and Form } \\
\text { Test and Final Questionnaire. }\end{array}$ \\
\hline September 2000 & $\begin{array}{l}\text { The tutors of these women complete the Final } \\
\text { Questionnaire. }\end{array}$ \\
\hline
\end{tabular}


Project Location and Design

The agency sponsoring the project is Lutheran Family Service (LFS) in Portland, Oregon. Lutheran Family Services is a social service agency that is a local affiliate of the national Lutheran Family Services located in Baltimore, Maryland. One function of LFS is to resettle refugees in the Portland area. When LFS resettles refugees, they set up the apartments with donated furniture and household goods for them. They also administer the 8 months of federally funded financial aid for the refugees. Since the numbers of refugees fluctuate each year, refugee agencies such as LFS are continually looking for additional projects to aid the refugees.

While one volunteer coordinator was researching new refugee projects to create, she discovered that after the Somali Benadir women had attended several months of English as a Second Language training supported with funding from the State of Oregon, they had acquired few language skills. She also discovered that these African women seemed to be unprepared to be successful in any English as a Second Language class because they face many barriers to success. These barriers include:

1. having little or no formal school experience,

2. being non-literate in English and pre-literate in their own language,

3. enduring the stress of caring for several children without aid of a husband or extended family,

4. feeling isolated living in a culture very different than their own, and

5. receiving pressure from Adult and Family Services to obtain work outside of the home, and post-traumatic stress. 
Instruments

Quantitative Methodology

Table II. Somali woman's pathway English proficiency and literary tests used for evaluation

\begin{tabular}{|c|c|c|c|}
\hline Name of Test & Time & $\begin{array}{l}\text { Administration } \\
\text { Method }\end{array}$ & Short Description \\
\hline The B.E.S.T. Test & $\begin{array}{l}5-20 \\
\text { minutes }\end{array}$ & $\begin{array}{l}\text { Investigator asks } \\
\text { student questions } \\
\text { orally, sometimes } \\
\text { using realistic } \\
\text { pictures. }\end{array}$ & $\begin{array}{l}\text { To test the women's } \\
\text { abilities to describe } \\
\text { themselves and } \\
\text { situations, tell time, } \\
\text { formulate questions and } \\
\text { discuss employment. }\end{array}$ \\
\hline $\begin{array}{l}\text { The B.E.S.T. B } \\
\text { Test }\end{array}$ & $\begin{array}{l}15-30 \\
\text { minutes }\end{array}$ & $\begin{array}{l}\text { Section One: } \\
\text { Investigator asks } \\
\text { student questions } \\
\text { orally, sometimes } \\
\text { using realistic } \\
\text { pictures. } \\
\text { Section Two: } \\
\text { Student fills out a } \\
\text { sort form in } \\
\text { writing. }\end{array}$ & $\begin{array}{l}\text { Tests the same content as } \\
\text { the B.E.S.T. Test and as } \\
\text { well as reading signs and } \\
\text { writing personal } \\
\text { information. }\end{array}$ \\
\hline The Alphabet Test & $\begin{array}{l}1-15 \\
\text { minutes }\end{array}$ & $\begin{array}{l}\text { The student fills } \\
\text { in letters of the } \\
\text { Roman alphabet } \\
\text { (some letters are } \\
\text { given as guides.) }\end{array}$ & $\begin{array}{l}\text { To test the Somali } \\
\text { women's ability to write } \\
\text { down the small letter and } \\
\text { capital letters of the } \\
\text { Roman alphabet. }\end{array}$ \\
\hline $\begin{array}{l}\text { The Form - } \\
\text { Literacy Test }\end{array}$ & $\begin{array}{l}1-15 \\
\text { minutes }\end{array}$ & $\begin{array}{l}\text { The student fills } \\
\text { out a form with } \\
\text { seven areas to fill } \\
\text { out. }\end{array}$ & $\begin{array}{l}\text { The Lutheran Family } \\
\text { Service Staff state that } \\
\text { all of the Somali women } \\
\text { would be able to fill out } \\
\text { a form that resembles an } \\
\text { Adult and Family } \\
\text { Services form after the } \\
\text { Somali women had } \\
\text { received } 72 \text { hours of } \\
\text { tutoring. The form also } \\
\text { asks for information that } \\
\text { Somali women would } \\
\text { encounter on a job } \\
\text { application. }\end{array}$ \\
\hline
\end{tabular}


Tests Used for Evaluation

The B.E.S.T. test-oral skills.

The investigator searched for an effective test that could be used to evaluate the program. Lutheran Community Services coordinators did not have any suggestions for competency tests. The most appropriate and wellresearched test for achievement of oral skills was found to be the B.E.S.T. Test (The Basic English Skills Test) (1982). The Somali women's command of spoken English was tested with the B.E.S.T. Test.

According to the Mental Measurements Yearbook (1992), the B.E.S.T. Test is a non-academic test designed to test listening comprehension, speaking, reading and writing skills at a basic level (Rathmell, 1992.). It can be used to determine placement, progress and program evaluation. The B.E.S.T. Test, developed by the Center for Applied Linguistics in the 1970's by a group of ESL teachers, administrators and test developers with the support of the United States Government Office of Refugee Resettlement, is a competency-based exam and does not focus solely on academic English skills. The B.E.S.T. Test included questions using realistic photos from a North American context (there are no Africans in the photos) and commonly used vocabulary. It tests the subjects' ability to listen, answer, describe life situations, ask for directions, and state opinions.

The B.E.S.T. Test has a high predictive validity according to the 1992 edition of the Mental Measurements Yearbook (Rathmell, 1992). It is very 
effective in testing students with very low levels of English that other tests cannot do.

The B.E.S.T. Test Short form was used as the pre-test for the Somali women. It was administered before they received any tutoring from the Removing Barriers volunteers. The B.E.S.T. Test was appropriate for the Somali women because it allowed them to answer orally. Many of the Somali women had little experience reading English before the tutoring sessions.

The B.E.S.T. Test Short form is primarily oral consequently students with minimal language skills are able to answer some of the questions and feel some sense of success. The students are only asked the questions orally; they are not allowed to read them. Some of the questions are simple. For example:

"What is your name?"

"Where are you from?"

"How long have you lived in the United States?"

The students encounter more complicated questions when they were faced with pictures and a set of questions to go along with each photo. There are several verb tenses demonstrated in the questions. The verb tenses include present, present progressive, present conditional and simple past. The more complicated questions include: 
"This woman wants to go the post office and she is lost. What question does she ask?" (The picture shows a woman with a map talking to a man on a street.)

"How do you think he feels?" (The picture shows a boy with a bicycle who appears to have been hit by a car.)

"What are they going to do next?" (This asks about the people in the bicycle accident photo.)

Two of the questions on the B.E.S.T. Short Form ask about time. One question requires the student to tell the time by reading a picture of a clock face on paper. The other questions inquire about the time the subject had gotten up in the morning. The subject is tested on her skills of reading time from a picture of a clock with hands.

One of the questions asks the subject to spell her name orally. Two of the questions ask the subject to formulate questions. Most of the Somali women could spell their first names easily, and many counted each letter of their name with their hands as they said them aloud as they answered.

Another question asks, "In your estimation, was the youngster neglectful?"' In the case of this particular question, the test administrator is not looking for a straight answer to the question, rather if the student asks for some type of clarification, she will receive a point.

Ten of the communication questions are scored on a scale of $0-2$ with 20 points possible. On two other communication-related questions, the testers 
are able to only receive a score of 0 or 1 with 2 total points possible. For the fluency questions, the subject receives two points if the answer she gives is comprehensible and grammatically correct, one point if the answer is comprehensible but not grammatically correct, and no points if there is no answer given or the answer is incomprehensible and inappropriate (Center for Applied Linguistics, 1989).

One of the communication questions requires the subject to demonstrate her knowledge of real currency. The administrator offers the subject three one-dollar bills, two quarters, two dimes, two nickels, and four pennies and instructs the subject to physically show $\$ 2.67$ with a combination of real United States dollars and coins.

The six fluency-related questions are scored on a scale of 0-3 with 18 points possible. The subject receives three points if the answer was elaborate (more than a few words), two points if the answer is shorter, not so elaborate and showing effort beyond the minimum, one point if the response is as minimal as possible and no elaboration was given, and no points if there is no response, or if the answer was incomprehensible or inappropriate (Center for Applied Linguistics, 1989).

To be able to administer the B.E.S.T. Test officially, one must be trained with a series of videos and group practice sessions. The administrator of the tests for the Somali women had been trained a year before the evaluation project. 
The B.E.S.T. Test Short Form is scored on a scale of $0-34+$ points.

Each score is correlated with a series of skills. Thus, the test can identify

what types of activities and work the student can perform. The abilities and

the performance levels are indicated in the chart below.

Table III. B.E.S.T. Test score levels and predicted abilities

\begin{tabular}{|c|c|c|}
\hline $\begin{array}{l}\text { B.E.S.T. Short } \\
\text { Form }\end{array}$ & $\begin{array}{l}\text { Student } \\
\text { Performance } \\
\text { Level (SPL) }\end{array}$ & Description \\
\hline $0-4$ & $\overline{0}$ & No ability. \\
\hline $5-7$ & I & $\begin{array}{l}\text { Functions minimally, if at all in English; } \\
\text { communicates only though gestures. }\end{array}$ \\
\hline $8-15$ & 11 & $\begin{array}{l}\text { Functions in a very limited way in } \\
\text { situations related to immediate needs; uses } \\
\text { only very simple learned phrases. }\end{array}$ \\
\hline $16-22$ & III & $\begin{array}{l}\text { Functions with some difficulty in } \\
\text { situations related to immediate needs; } \\
\text { only the most basic oral communication } \\
\text { abilities. }\end{array}$ \\
\hline $23-26$ & IV & $\begin{array}{l}\text { Can satisfy basic survival needs and a few } \\
\text { very routine social demands; some simple } \\
\text { oral communication abilities. }\end{array}$ \\
\hline $27-29$ & V & $\begin{array}{l}\text { Can satisfy basic survival needs and some } \\
\text { limited social demand; can follow simple } \\
\text { oral and very basic written instructions. }\end{array}$ \\
\hline $30-33$ & VI & $\begin{array}{l}\text { Can satisfy basic survival needs and } \\
\text { limited social demands; can follow simple } \\
\text { oral and written instructions and diagrams. }\end{array}$ \\
\hline $34+$ & VII & $\begin{array}{l}\text { Can satisfy survival needs and routine } \\
\text { work and social demands; can follow oral } \\
\text { and simple written instructions in familiar } \\
\text { and some unfamiliar situations. }\end{array}$ \\
\hline
\end{tabular}

B.E.S.T. test form $b$.

While the B.E.S.T. Short Form has only 18 questions, Form B, which was used as the post-test has forty-nine questions and includes a written portion. 
Fifteen of the questions from the B.E.S.T. Short Form are the same on Form B. Both tests ask the subject to demonstrate knowledge of real money. There are more forms of knowledge questioned in Form B. The subject must listen to directions and physically show directions on a simple map of a neighborhood. The subject must demonstrate reading skills. The subject is shown one or two words describing a scene such as a "bus stop." The subject is then presented with a paper with three pictures on it. The subject must show the picture that is described by the words she read.

Part of Form B is a written section. The subject must fill out a sample form and write her name, address, signature and date.

The B.E.S.T. Test Form B was supposed to be administered when the student had completed her 72 hours of tutoring. However, only four Somali women completed the entire 72 hours of tutoring.

Alphabet and literacy test in English.

A test of written English was developed solely for this evaluation project. The program director of the Somali Project at Lutheran Family Service predicted that after the tutoring project that the women would be able to write the letters of the alphabet and fill out a form, as one would be asked to complete at an Adult and Family Service office. This test was piloted on twenty-five low-level and five intermediate level English as a Second Language students at Clark Community College in Vancouver, Washington. Twenty-three of the students in this pilot were refugees. 
The alphabet test.

The first part of the literacy test requires the women to write letters of the Roman alphabet. There are two sections to the alphabet test: small letters and capital letters. There are 26 lines in a row with some of the letters already typed on the page. The small letters $a, b, m, p, t$, and $y$ as well as the capital letters "A", "G", "M", "P" and "Y" of the alphabet are given as guides. On the second part of the test, the women must demonstrate the ability to read a form and fill it out. This test was field tested with 30 students who were refugees studying English as a Second Language at Clark College in Vancouver, Washington. These students were enrolled in the lowest level class of the community college program.

Literacy test.

Another test that was developed for this evaluation project was the "Fill in the Form" test. This was modeled after common forms that the Adult and Family Services use. The subject is given a form that requires her to fill in personal information such as her full name, date of birth, address and phone numbers. It asks for household size and to check off the types of social services (AFDC/TANF for financial assistance, Medicaid for heath assistance, and Food Stamps for food assistance.)

There is also a section that asks for the names, sex and age of the subject's children. At the end, the subject must sign and date the form. 
A test of writing skills is also included in the extended form or the

B.E.S.T. Test that the women completed at the end of their tutoring. For this test, the women had to fill out their name, address and phone number.

\section{Qualitative Methodology}

The qualitative portion of this program evaluation include

questionnaires for the Somali women, the North American tutors, interviews

with the staff members of Lutheran Family Services and several of the tutors, and some tutoring observations

Table IV. Somali women's surveys

\begin{tabular}{|c|c|c|c|}
\hline Name & $\begin{array}{l}\text { Number } \\
\text { of } \\
\text { Questions }\end{array}$ & Topics & $\begin{array}{l}\text { Administratio } \\
\text { n Methods }\end{array}$ \\
\hline $\begin{array}{l}\text { Student Pre- } \\
\text { Survey }\end{array}$ & 12 & $\begin{array}{l}\text { Types of print in English } \\
\text { available in the home, } \\
\text { Somali literacy } \\
\text { proficiency, English } \\
\text { ability and learning } \\
\text { experience, time expected } \\
\text { to spend studying } \\
\text { everyday, looking forward } \\
\text { to meeting tutor, goals. }\end{array}$ & $\begin{array}{l}\text { Oral - } \\
\text { Investigator } \\
\text { and Somali } \\
\text { Interpreter } \\
\text { interviewed the } \\
\text { students at } \\
\text { their homes. }\end{array}$ \\
\hline $\begin{array}{l}\text { Student Post- } \\
\text { Survey }\end{array}$ & 14 & $\begin{array}{l}\text { Types of print in English } \\
\text { available in the home, } \\
\text { Somali literacy } \\
\text { proficiency, English ability } \\
\text { and learning experience, } \\
\text { time expected to spend } \\
\text { studying everyday, } \\
\text { friendship with tutor, } \\
\text { goals, suggestions for } \\
\text { future programs, and } \\
\text { additional comments. }\end{array}$ & $\begin{array}{l}\text { Oral - } \\
\text { Investigator } \\
\text { and Somali } \\
\text { Interpreter } \\
\text { interviewed } \\
\text { the students at } \\
\text { their homes. }\end{array}$ \\
\hline
\end{tabular}


$\underline{\text { Table V. Tutors' and staff surveys and questionnaires }}$

\begin{tabular}{|c|c|c|c|}
\hline Name & $\begin{array}{l}\text { Number of } \\
\text { Questions }\end{array}$ & Topics & $\begin{array}{l}\text { Administration } \\
\text { Methods }\end{array}$ \\
\hline $\begin{array}{l}\text { Tutor's Pre- } \\
\text { Survey }\end{array}$ & 10 & $\begin{array}{l}\text { Tutoring expectations } \\
\text { and experience, cultural } \\
\text { experience, experience in } \\
\text { Africa. }\end{array}$ & $\begin{array}{l}\text { Most filled out } \\
\text { the surveys } \\
\text { during the first } \\
\text { cultural } \\
\text { orientation. A } \\
\text { few surveys } \\
\text { were conducted } \\
\text { over the phone. }\end{array}$ \\
\hline $\begin{array}{l}\text { Tutor's } \\
\text { Midterm } \\
\text { Questionnaire }\end{array}$ & 6 & $\begin{array}{l}\text { Tutoring experience, } \\
\text { tutoring materials. }\end{array}$ & $\begin{array}{l}\text { Oral - Most } \\
\text { answered } \\
\text { questions the } \\
\text { investigator } \\
\text { asked at filled } \\
\text { out the surveys } \\
\text { during the first } \\
\text { cultural } \\
\text { orientation. A } \\
\text { few surveys } \\
\text { were conducted } \\
\text { over the phone. }\end{array}$ \\
\hline $\begin{array}{l}\text { Tutor's Post } \\
\text { Survey }\end{array}$ & 16 & $\begin{array}{l}\text { Outcomes of tutoring } \\
\text { experience with Somali } \\
\text { woman, cultural comfort, } \\
\text { opinions of LFS } \\
\text { language and cultural } \\
\text { training, opinions of LFS } \\
\text { support, opinions about } \\
\text { program's cause and } \\
\text { content. }\end{array}$ & $\begin{array}{l}\text { Most filled out } \\
\text { the surveys } \\
\text { during the first } \\
\text { cultural } \\
\text { orientation. A } \\
\text { few surveys } \\
\text { were conducted } \\
\text { over the phone. }\end{array}$ \\
\hline $\begin{array}{l}\text { Staff Pre and } \\
\text { Post Surveys }\end{array}$ & 5 & $\begin{array}{l}\text { The staff predicted } \\
\text { outcomes during the pre- } \\
\text { survey and discussed } \\
\text { results during the post- } \\
\text { survey. }\end{array}$ & $\begin{array}{l}\text { The staff was } \\
\text { asked the } \\
\text { questions orally } \\
\text { in the office. }\end{array}$ \\
\hline $\begin{array}{l}\text { Tutoring } \\
\text { Observations }\end{array}$ & $\begin{array}{l}\text { Not } \\
\text { applicable }\end{array}$ & $\begin{array}{l}\text { Interaction styles } \\
\text { between the tutor and } \\
\text { student during tutoring } \\
\text { sessions were noted. }\end{array}$ & $\begin{array}{l}\text { The investigator } \\
\text { sat behind the } \\
\text { student and tutor } \\
\text { and wrote notes } \\
\text { while observing } \\
\text { the tutoring } \\
\text { sessions. }\end{array}$ \\
\hline
\end{tabular}


The student pre and post-survey.

The Somali women completed the surveys when they finished the pre and post tests. The survey questions were formulated with the staff at Lutheran Family Services. The basic themes of the questions include what the women think about learning English and the support they received from their family. It also asks the women to self-report about their English and Somali literacy skills and previous history of studying English in the United States. They are asked to list any reading materials they have at home. The women are asked to give their goals while participating in the program and to report on their progress at the end of the program.

The tutor and staff pre and post-survey.

The tutor surveys ask the tutors about their teaching experience and exposure to African countries. It asks them to report about their relationships with the Somali women and the amount of time they spend time preparing for each tutoring session. The staff surveys record the staff expectations of the programs and their final impressions and suggestions for future programs.

The tutor mid-term questionnaire.

The mid-term questionnaire asks the tutors to report on their impressions from tutoring the Somali women around 30 hours. The tutors give their impressions of the teaching materials they received from Lutheran Family Service and their thoughts about teaching the women in their homes. 
Tutoring observations.

Three Somali women and three tutors were observed at three points during the teaching process. The investigator observes the tutoring sessions for one hour each time. The investigator took notes on the teaching styles, interactions and environmental factors during the observations.

The Population - The Benadir from Somalia who Reside in Portland

The Lutheran Family Service Pathways Program was designed to help refugees from Somalia who have been in the United States for more than one year and who have not been able to become employed full-time. One of the main goals of government funded refugee programs in the United States is to make sure that all of the refugees become self-sufficient so that they will not be dependent upon any type of welfare. The Pathways Program was designed to help the women acquire literacy skills in English so that they could become self-sufficient and employable in the United States society. The program had a goal of getting eight women employed full-time before the end of the program. By having the tutors come to the homes of the Benadir, the program organizers hoped that the Somali women would become more familiar and at ease with American culture and make some American friends.

The population in the study was a group of women who had been brought to the United States as refugees. In 1996, 6,000 Benadir refugees came from Somalia. The Benadir were resettled all over the United States. Most of the women came to Oregon because they were assigned by a 
voluntary agency to come to Portland, Oregon. There are about 200 Benadir in Portland, Oregon. They live close to each other clustered in Northeast and Southwest. Some of them came to join their Benadir friends in Oregon after having been first resettled in other states. A few of the women have husbands, but most are single mothers.

Most of the women in the Pathways Program had attended English classes provided by programs funded by the State of Oregon and the Office of Refugee Resettlement and had not acquired any noticeable literacy skills in English. The developer of the Pathways Program postulated that the women had not learned English because they were not used to functioning in a classroom setting, and that they did not have enough basic English skills to be successful in a group learning situation. Many of the women did not complete school in Somalia and did not have a basic command of English. Thus, the Pathways program was designed to break the Benadir women's barriers to learning English. The barriers include transportation (most of the women could not drive), having little or no experience in a formal school situation, having several children to care for (many who were under the age of seven), having the fear of failing at learning a language, and having little direct contact with United States native speaking citizens.

The program was created to give the women a one-on-one learning situation. Since the Benadir women had several children to look after and 
they did not drive, the tutors came to the home of the refugees for each tutoring session. 


\section{CHAPTER FOUR}

\section{Results and Discussion}

In this chapter, the results of the various tests and surveys are reported. This includes the total tutoring hours accomplished, the surveys (the pre and post-surveys for the Somali Women, the pre and post-surveys for the North American tutors and the pre and post-surveys of the Lutheran Family Services Staff) and certain results of the tests (the B.E.S.T. Test, the B.E.S.T. B Test, the Alphabet Test, and the Form Test.) 
Table VI. Program results - amount of tutoring hours completed

\begin{tabular}{|c|c|c|c|}
\hline $\begin{array}{l}\text { Number of } \\
\text { Somali } \\
\text { Participants }\end{array}$ & $\begin{array}{l}\text { Participant } \\
\text { ldentification } \\
\text { Number }\end{array}$ & $\begin{array}{l}\text { Total Number of } \\
\text { Tutoring Hours } \\
\text { Completed }\end{array}$ & $\begin{array}{l}\text { Percentage of Total Hours } \\
\text { of Tutoring }\end{array}$ \\
\hline 1. & 102 & 53 & $74 \%$ \\
\hline 3. & 104 & 42 & $58 \%$ \\
\hline 5. & 106 & 20 & $28 \%$ \\
\hline 6. & 107 & 49 & $68 \%$ \\
\hline 7. & 108 & 52 & $72 \%$ \\
\hline 8. & 109 & 51 & $71 \%$ \\
\hline 9. & 110 & 8 & $11 \%$ \\
\hline 10. & 120 & 51 & $71 \%$ \\
\hline 11. & 130 & 24 & $34 \%$ \\
\hline 12. & 140 & 16 & $22 \%$ \\
\hline 14. & 160 & 64 & $89 \%$ \\
\hline 15. & 170 & 56 & $78 \%$ \\
\hline 16. & 180 & 64 & $89 \%$ \\
\hline 17. & 190 & 56 & $78 \%$ \\
\hline 18. & 200 & 12 & $17 \%$ \\
\hline 19. & 210 & 72 & $100 \%$ \\
\hline 20. & 220 & 42 & $58 \%$ \\
\hline 21. & 230 & 22 & $31 \%$ \\
\hline 22. & 240 & 72 & $100 \%$ \\
\hline 23. & 250 & 14 & $19 \%$ \\
\hline 24. & 260 & 54 & $75 \%$ \\
\hline 25. & 270 & 72 & $100 \%$ \\
\hline 26. & 280 & 20 & $28 \%$ \\
\hline 27. & 290 & 72 & $100 \%$ \\
\hline 28. & 300 & 21 & $29 \%$ \\
\hline 29. & 310 & 47 & $65 \%$ \\
\hline 30. & 320 & 36 & $50 \%$ \\
\hline 31. & 330 & 62 & $86 \%$ \\
\hline
\end{tabular}


The Total Number of Tutoring Hours Completed

As is indicated by the graph above, not all of the Somali women completed the tutoring program. Of the 31 Somali women tested in the fall of 1999 , three were dropped from the study because they became employed or they suffered from health difficulties that prevented them from participating the post testing. Of the 28 women remaining in the study, only four completed the total 72 hours of tutoring.

Table VII. Percentage of Tutoring Hours Completed

\begin{tabular}{|c|c|c|}
\hline $\begin{array}{l}\text { Percentage of Tutoring } \\
\text { Hours Completed }\end{array}$ & $\begin{array}{l}\text { Percentage } \\
\text { of Women }\end{array}$ & $\begin{array}{l}\text { Number of } \\
\text { Women }\end{array}$ \\
\hline $\begin{array}{l}\text { completed } 100 \% \\
\text { (72 hours total) }\end{array}$ & $14 \%$ & 4 women \\
\hline $\begin{array}{l}\text { completed } 80-89 \% \\
(62-64 \text { hours })\end{array}$ & $11 \%$ & 3 women \\
\hline $\begin{array}{l}\text { completed } 70-79 \% \\
(51-56 \text { hours })\end{array}$ & $25 \%$ & 7 women \\
\hline $\begin{array}{l}\text { completed } 60-69 \% \\
(47-49 \text { hours) }\end{array}$ & $7 \%$ & 2 women \\
\hline $\begin{array}{l}\text { completed } 50-58 \% \\
\text { ( } 36-42 \text { hours) }\end{array}$ & $11 \%$ & 3 women \\
\hline $\begin{array}{l}\text { completed } 31-34 \% \\
\text { (22-24 hours) }\end{array}$ & $7 \%$ & 2 women \\
\hline $\begin{array}{l}\text { completed } 20-29 \% \\
\text { (16-21 hours) }\end{array}$ & $14 \%$ & 4 women \\
\hline $\begin{array}{l}\text { completed } 10-19 \% \\
(8-14 \text { hours) }\end{array}$ & $11 \%$ & 3 women \\
\hline
\end{tabular}

With only 14 percent of the Somali women completing the entire 72 hours of instruction, the process of comparing student progress becomes difficult. The coordinator of the Pathways Program hypothesized that a 
majority of the participants would finish their 72 hours.

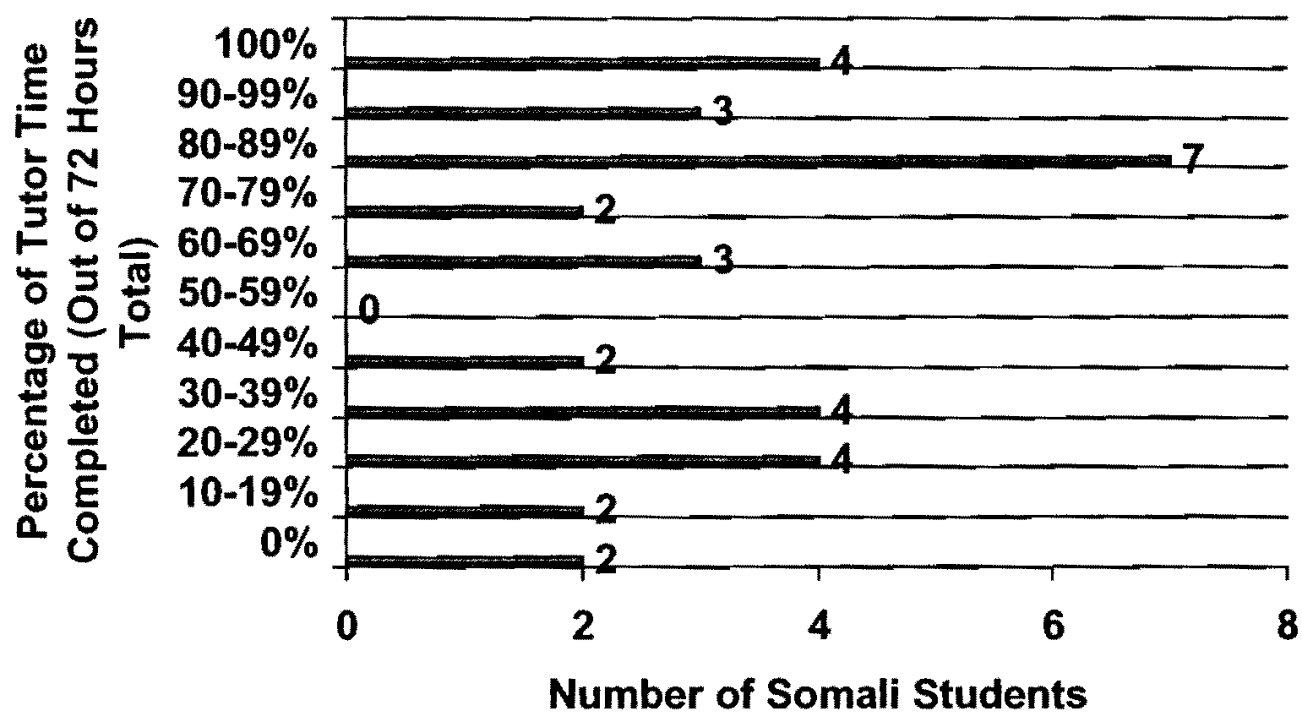

Figure 2 Total Number of Tutoring Hours Finished

The Pre and Post Surveys for the Somali Women

The first question on the Somali participants' survey asks the student

to list the types of print they noticed or have around their house. Elsa

Auerbach states that,

Children acquire literacy over a period of years; there is no reason to assume that adults will make dramatic changes in less than one year. However by looking at the work ... as well as approach learner assessment in a qualitative way, we were able to make some generalizations about the impact of the model on learners... We asked, 'How are learners' literacy practices changing?' We were concerned about what learners said or showed about literacy and English in their lives rather than with test scores." Auerbach used anecdotes, posted journals and student selfevaluation (Auerbach, 1996, p.3). 
The pre-survey demonstrated that 10 Somali women (36\%) reported having print in English around their home. The print came from mail (2), storybooks (2), newspaper (3), and children's homework (3). In the postsurvey, 15 women $(54 \%)$ stated that they had print around their house. Of this, 2 were storybooks, 10 were children's homework, and 3 were labels on food cans. The increase of 10 to fifteen women reporting texts indicates that $18 \%$ increase in noticing print in English in the home environment.

Table VIII. Perception of difficulty of learning English

\begin{tabular}{|llll|}
\hline $\begin{array}{l}\text { Perception } \\
\text { of Difficulty } \\
\text { of Learning } \\
\text { English }\end{array}$ & $\begin{array}{l}\text { Pre-Survey Learning } \\
\text { English Will Be Difficult }\end{array}$ & $\begin{array}{l}\text { Post-Survey } \\
\text { Learning English } \\
\text { Was Difficult }\end{array}$ & Results \\
\hline Yes & 18 & 10 & -8 \\
No & 8 & 15 & +7 \\
\hline
\end{tabular}

Before the tutoring began, 18 Somali women stated that they thought that learning English would be difficult. Eight reported that they did not think that learning English would be difficult, and two did not answer the question. After the tutoring, 10 reported that learning English was difficult, and 15 stated that they considered learning English an activity that was not difficult for them. 
Table IX. Self-reported ability to read and write in Somali

\begin{tabular}{|lllc|}
\hline $\begin{array}{l}\text { Self-Reported } \\
\text { Ability to Read } \\
\text { and Write in }\end{array}$ & Pre-Survey & Post-Survey & Results \\
Somali & & & \\
\hline Yes & 13 & 10 & -3 \\
No & 14 & 15 & +1 \\
\hline
\end{tabular}

On the pre-survey, 13 Somali stated that they could read and write in

Somali. Fourteen said that they were not literate in Somali, and one Somali woman did not answer the question. At the end of the program, 10 women reported that they could read and write in Somali, and 15 reported that they could not. Three women did not answer that question.

Table X. Studied English in the United States

\begin{tabular}{|lc|}
\hline Studied English in the United States & Pre-Survey \\
\hline Yes & 23 \\
No & 3 \\
\hline
\end{tabular}

Before the tutoring began in the United States, 23 Somali women reported to have completed some type of English language study. Only three stated that they had not obtained assistance in learning English. Fifteen of the women studied English for 4 months or longer. 
Table XI. How many months they studied English in the United States

\begin{tabular}{|ll|}
\hline $\begin{array}{l}\text { How Many } \\
\text { Months They } \\
\text { Studied English } \\
\text { in the United } \\
\text { States }\end{array}$ & Pre-Survey \\
\hline 0 & \\
2 months & 7 \\
3 months & 1 \\
4 months & 7 \\
6 months & 1 \\
8 months & 9 \\
9 months & 1 \\
\hline
\end{tabular}

Of the 23 who reported studying English as a Second Language in the United States, five women reported to have studied at PCC, five at Steps to Success, three at IRCO and one at a school in Maryland. Four Somali women did not indicate which institute they studied at.

Table XII. Where they studied English in the United States

\begin{tabular}{|ll|}
\hline $\begin{array}{l}\text { Where They Studied English } \\
\text { in the United States }\end{array}$ & $\begin{array}{l}\text { Pre- } \\
\text { Survey }\end{array}$ \\
\hline $\begin{array}{l}\text { IRCO (International Refugee } \\
\text { Center of Oregon) }\end{array}$ & 3 \\
$\begin{array}{l}\text { PCC (Portland Community } \\
\text { College) }\end{array}$ & 5 \\
Steps to Success & 5 \\
A School in Maryland & 1 \\
Not Specified & 4 \\
\hline
\end{tabular}


Thirteen reported that they had some literacy skills in English, and 14 stated that they had no skills. Concerning their literacy in English, six said that they could read English at a beginning level (letters of the alphabet and numbers only), eight reported that they could read short sentences, and one said that she could read simple books and forms. Fourteen said that they had no literacy skills in English. On the post survey, 22 women reported that they had literacy skills in English. Three reported having no skills. Seven women said that they could read letter and numbers, 6 women could read short sentences and 8 women could read simple books and forms in English.

Table VIII. Self-Reported Ability to Read in English

\begin{tabular}{|lccc|}
\hline $\begin{array}{l}\text { Self-Reported } \\
\text { Ability to Read in } \\
\text { English }\end{array}$ & Pre-Survey & Post-Survey & Results \\
\hline Yes & 13 & 22 & +9 \\
No & 14 & 3 & -11 \\
$\begin{array}{l}\text { Beginning } \\
\text { (letters and } \\
\text { numbers) }\end{array}$ & 6 & 7 & +1 \\
$\begin{array}{l}\text { Intermediate } \\
\text { (short } \\
\text { sentences) }\end{array}$ & 8 & 6 & -2 \\
$\begin{array}{l}\text { Advanced } \\
\text { (simple books } \\
\text { and forms) }\end{array}$ & 1 & 8 & \\
\hline
\end{tabular}

Alphabet Test

Almost all of the Somali women said their alphabet out loud as they tried to fill in the missing letters. Most of the women found that once they 
reached the letter " $\mathrm{k}$ " or "l" that they had to start naming the letters again beginning with "abc".

The next three questions required the women to report their ability to write in English. On the pre-survey, 20 reported being able to write the alphabet in English, 6 students stated that they could not write the alphabet, and two women did not answer the question. It is interesting to note that no one could write the alphabet (small and capital letters) in perfect order. Table XIV. Alphabet test

\begin{tabular}{|l|c|l|l|}
\hline $\begin{array}{l}\text { Self-Reported } \\
\text { Ability to } \\
\text { Write the } \\
\text { Alphabet }\end{array}$ & Pre-Survey & $\begin{array}{l}\text { Post- } \\
\text { Survey }\end{array}$ & Results \\
\hline Yes & 20 & 24 & 4 \\
No & 6 & 2 & -2 \\
\hline
\end{tabular}

On the post survey, 24 Somali women stated that they could write the alphabet in English. However, the scores shown in Table XV below indicate that none of the women were able to complete the alphabet fill-in exercises including small and capital letters perfectly after they had received tutoring. 
Table XV. Alphabet Test Scores

\begin{tabular}{|ll|}
\hline $\begin{array}{l}\text { Score (Out of 41 } \\
\text { Total) }\end{array}$ & $\begin{array}{l}\text { Number of Somali } \\
\text { Women }\end{array}$ \\
\hline 0 & 3 \\
3 & 2 \\
7 & 2 \\
8 & 1 \\
9 & 4 \\
10 & 1 \\
12 & 1 \\
18 & 1 \\
20 & 2 \\
22 & 3 \\
23 & 1 \\
29 & 1 \\
30 & 1 \\
32 & 2 \\
36 & 1 \\
39 & 1 \\
\hline & Literacy Self-Reported Abilities and Tests \\
\end{tabular}

Since many of the Somali women did not have experience writing, being required to complete a written test was frightening. Eight of the women told the administrator that they could not do the written test because they could not find their glasses. However, after some encouragement, all of the women attempted to complete the written portions. 
Table XVI. Self-Reported Ability to Write Sentences in English

\begin{tabular}{|lccc|}
\hline Self-Reported & Pre-Survey & Post-Survey & Results \\
Ability to & & & \\
Write & & & \\
$\begin{array}{l}\text { Sentences In } \\
\text { English }\end{array}$ & 8 & 17 & +9 \\
\hline Yes & 19 & 9 & -10 \\
No & 5 & 14 & +9 \\
Basic (3-5 & & & \\
words) & 4 & 11 & +7 \\
Long (more & & & \\
than 5 words) & & & \\
\hline
\end{tabular}

Although writing sentences in English was not explicitly tested during this research, the increased numbers of self-reported ability to write sentences is noteworthy. Nine more women reported being able to write sentences after the tutoring program was completed. As for applications, at the end of the program, five more women (10 women total) were able to complete an application in English than at the beginning of the program.

Table XVII. Self-Reported Ability to Fill Out a Job Application in English

\begin{tabular}{|llll|}
\hline Self-Reported & Pre-Survey & Post-Survey & Results \\
Ability to Fill & & \\
Out a Job & & & \\
Application In & & & \\
English & 5 & 10 & +5 \\
\hline Yes & 22 & 15 & -7 \\
No & & & \\
\hline
\end{tabular}


The number of women reporting the ability to speak on the phone in English improved by three (14 women total) during the post-survey. Before the program began, only 11 women stated that they could speak on the phone in English.

Table XVIII. Self-Reported Ability to Speak On the Phone in English

\begin{tabular}{|llll|}
\hline $\begin{array}{l}\text { Self-Reported Ability } \\
\text { to Speak On the Phone } \\
\text { In English }\end{array}$ & Pre-Survey & $\overline{\text { Post-Survey }}$ & Results \\
\hline Yes & 11 & 14 & +3 \\
No & 13 & 11 & -2 \\
\hline
\end{tabular}

Affective Factors

Affective factors, including the encouragement that the women's family gave for studying English, and the way the Somali women perceived their tutors are reported below. The number of families who encouraged the women to study remained at 21 before and after the program.

Table XIX. Family encourages the student to learn English

\begin{tabular}{|lccl|}
\hline $\begin{array}{l}\text { Family } \\
\text { Encourages the }\end{array}$ & Pre-Survey & Post-Survey & Results \\
Student to Learn & & & \\
English & & & \\
\hline Yes & 21 & 21 & No change \\
No & 5 & 4 & -1 \\
\hline
\end{tabular}

The questions included asked if the Somali women were looking forward to meeting their teacher and if they became friends by the end of the program. The final results demonstrated that three women did not end up considering their tutor as a friend. 
Table XX. Student is looking forward to meeting her tutor

\begin{tabular}{|c|c|c|c|}
\hline $\begin{array}{l}\text { Student is } \\
\text { Looking Forward } \\
\text { to Meeting Her } \\
\text { Tutor }\end{array}$ & Pre-Survey & $\begin{array}{l}\text { Post-Survey } \\
\text { (Became } \\
\text { Friends with } \\
\text { Tutor) }\end{array}$ & Results \\
\hline Yes & 25 & 22 & -3 \\
\hline No & 2 & 2 & No change \\
\hline
\end{tabular}

The teachers received an overwhelming approval rating from the Somali women. Only two women reported that they did not find their tutors to be effective teachers while twenty-two women reported their satisfaction with their tutor's teaching style.

Table XXI. Student said that tutor was a good teacher

\begin{tabular}{|lc|}
\hline $\begin{array}{l}\text { Student Said that Tutor was a Good } \\
\text { Teacher }\end{array}$ & Post-Survey \\
\hline Yes & 22 \\
No & 2 \\
\hline
\end{tabular}

Student Self-Reported Progress, Study Habits and Achievement of Goals

The Somali women were asked to report how much they planned to study as well as how much they studied, what their goals were and whether they achieved their goals or not. At the beginning, 26 women had planned to study English more than 1 hour a day, but at the end, only 17 women reported doing so. 
Table XXII. Student studies more than one hour a day (or more)

\begin{tabular}{|llll|}
\hline $\begin{array}{l}\text { Student } \\
\text { Studies More } \\
\text { than One Hour }\end{array}$ & Pre-Survey (plans to) & $\begin{array}{l}\text { Post-Survey (did } \\
\text { study more than } \\
\text { one hour) }\end{array}$ & \\
More) & & & \\
\hline Yes & 26 & 17 & -9 \\
No & 1 & 8 & +7 \\
\hline
\end{tabular}

Thirteen out of 27 women reported achieving their goals by the end of

their tutoring sessions.

Table XXIII. Student reports to have achieved her goals

\begin{tabular}{|ll|}
\hline Student Reports to Have & Post-Survey \\
Achieved Her Goals & \\
\hline Yes & 13 \\
No & 11 \\
\hline
\end{tabular}

The most popular women's goals included being able to speak

English and to be able to speak with a doctor in English. The women also indicated that being able to talk on the telephone, being able to read in English and being able to communicate while shopping, and being able to talk with the teachers of their children were important. Obtaining a job was a goal for only 4 Somali participants. 
$\underline{\text { Table XXV. Students' goals }}$

\begin{tabular}{|ll|}
\hline Students' Goals & Pre-Survey \\
\hline To Speak English & 15 \\
To Be Able to Speak with a Doctor in English & 13 \\
To Talk on the Telephone & 6 \\
To Be Able to Read in English & 5 \\
To Be Able to Shop & 5 \\
To Be Able to talk with Teachers & 5 \\
To Write English & 4 \\
To Get a Better Job & 4 \\
To Help Children with Homework & 3 \\
To Go to School/College & 3 \\
To Be Able to Interpret for other Somali Women & 1 \\
\hline
\end{tabular}

The Tutor and Staff Pre and Post-Survey

Twenty-two of the tutor pre-surveys were completed during the literacy training held at Lutheran Family Service. Five of the surveys were completed over the phone and 1 participant sent the survey to the investigator.

\section{Affective Factors}

On the Pre-Survey, eighteen tutors reported that they thought that English would be difficult to teach and on the Post-Survey, only fourteen thought that English was not easy to teach. 
Table XXVI. Thinks English will be difficult to teach

\begin{tabular}{|c|c|c|c|}
\hline $\begin{array}{l}\text { Thinks English Will } \\
\text { be Difficult to Teach }\end{array}$ & $\begin{array}{l}\text { Pre- } \\
\text { Survey }\end{array}$ & $\begin{array}{l}\text { Post- } \\
\text { Survey }\end{array}$ & Results \\
\hline Yes & 18 & 14 & -4 \\
\hline No & 8 & 9 & +1 \\
\hline
\end{tabular}

It is interesting that one less person reported feeling comfortable with people who do not speak English at the end of the program. For the topic of feeling comfortable entering a Somali household, the numbers increased by two from 19 women at the beginning to 21 women at the end.

Table XXVII. Feel comfortable with people who do not speak English

\begin{tabular}{|lccc|}
\hline Feels Comfortable With & Pre-Survey & Post-Survey & Results \\
People Who Do Not Speak & & & \\
English & & & -1 \\
\hline Yes & 21 & 20 & +1 \\
No & 2 & 3 & \\
\hline
\end{tabular}

Table XXVIII. Feels comfortable entering a Somali home

\begin{tabular}{|lccc|}
\hline Feels Comfortable & Pre-Survey & Post-Survey & Results \\
Entering a Somali & & & \\
Home & 19 & 21 & +2 \\
\hline Yes & 4 & 2 & -2 \\
\hline
\end{tabular}

On the Pre-Survey, 21 women reported that they intended to become friends with their students but on the Post-Survey end, only 20 reported being able to establish a friendship. 
Table XXIX. Tutor hopes to become a friend with her student

\begin{tabular}{|lcll|}
\hline $\begin{array}{l}\text { Tutor Hopes to Become a } \\
\text { Friend With Her Student }\end{array}$ & Pre-Survey & $\begin{array}{l}\text { Post-Survey } \\
\text { (Became } \\
\text { Friends with } \\
\text { Student) }\end{array}$ & Results \\
\hline Yes & 21 & 20 & -1 \\
No & 2 & 2 & $\begin{array}{l}\text { No } \\
\text { Change }\end{array}$ \\
\hline
\end{tabular}

Tutor plans to spend more than one hour a day to prepare lessons for the tutoring sessions. After the tutoring period was over, only five tutors reported spending more than one hour a day preparing lessons.

Table XXX. Tutor plans to spend more than one hour a day to prepare

\begin{tabular}{|llll|}
\hline $\begin{array}{l}\text { Tutor Plans to Spend } \\
\text { More than One Hour a } \\
\text { Day to Prepare Her }\end{array}$ & Pre-Survey & $\begin{array}{l}\text { Post- } \\
\text { Survey }\end{array}$ & Results \\
Lessons & & & \\
\hline Yes & 10 & 5 & -5 \\
No & 14 & 17 & +3 \\
\hline
\end{tabular}

Thirteen of the twenty tutors stated that they could read and write in a foreign language.

Table XXXI. Tutor can read and write in a foreign language

\begin{tabular}{|llll|}
\hline $\begin{array}{l}\text { Tutor Can Read and Write in a } \\
\text { Foreign Language }\end{array}$ & $\begin{array}{l}\text { Pre- } \\
\text { Survey }\end{array}$ & $\begin{array}{l}\text { Post- } \\
\text { Survey }\end{array}$ & Results \\
\hline Yes & 13 & 14 & +1 \\
No & 10 & 8 & -2 \\
\hline
\end{tabular}

Thirteen North American tutors had experience helping someone to fill out a job application before the tutoring program began. 
Table XXXII. Tutor has experience assisting someone to fill out a job application

\begin{tabular}{|lc|}
\hline Tutor Has Experience & Pre-Survey \\
Assisting Someone to & \\
Fill Out a Job & \\
Application & 13 \\
\hline Yes & 10 \\
No & \\
\hline
\end{tabular}

Before the tutoring began, thirteen tutors reported having experience working with refugees.

Table XXXIII. Tutor has experience working with refugees

\begin{tabular}{|ll|}
\hline $\begin{array}{l}\text { Tutor Has Experience Working } \\
\text { with Refugees }\end{array}$ & Pre-Survey \\
\hline Yes & 13 \\
No & 10 \\
\hline
\end{tabular}

\section{Experience in Africa}

Six North American tutors reported traveling to Africa. Only one tutor had been to Somalia. The other countries the women had visited included Botswana, Ethiopia, Kenya, Namibia, South Africa, Swaziland, and Zimbabwe. The women's stays ranged from one month to three years. In Africa, they were tourists, United States Foreign Service officers and Peace Corps members.

Table XXXIV. Tutor has traveled to Africa

\begin{tabular}{|lc|}
\hline Tutor Has Traveled to Africa & Pre-Survey \\
\hline Yes & 6 \\
No & 17 \\
\hline
\end{tabular}


Table XXXV. The Places tutors have visited in Africa

\begin{tabular}{|ll|}
\hline $\begin{array}{l}\text { The Places the Tutors Have Visited } \\
\text { in Africa }\end{array}$ & Pre-Survey \\
\hline Somalia & 1 \\
Botswana & 1 \\
Ethiopia & 1 \\
Kenya & 2 \\
Namibia & 1 \\
South Africa & 1 \\
Swaziland & 1 \\
Zimbabwe & 3 \\
\hline
\end{tabular}

E.S.L. and Literacy Tutoring Experience

Thirteen out of 23 tutors reported having tutoring experience.

Table XXXVI. Tutor has tutoring experience

\begin{tabular}{|ll|}
\hline Tutor Has Tutoring Experience & Pre-Survey \\
\hline Yes & 13 \\
No & 10 \\
\hline
\end{tabular}

The North American women's tutoring experiences ranged from teaching English as a Second Language to adults to teaching children how to read and write. One tutor had experience using the Laubach Method. 
Table XXXVII. What the tutor taught

\begin{tabular}{|ll|}
\hline What the Tutor Taught & Pre-Survey \\
\hline ESL & 3 \\
ESL with Laubach Method & 1 \\
Adult Literacy (With Native Speakers of & 8 \\
English) & \\
Literacy for Children & 1 \\
\hline
\end{tabular}

The tutors worked with students from a number of cultures before they started the volunteer with the Somali program. The various nationalities included Somali, Bolivian, Hispanic, North American, Peruvian, Taiwanese and Russian. Only two tutors had experience teaching Somalis.

Table XXXVIII. The population the tutor worked with

\begin{tabular}{|ll|}
\hline The Population the Tutor & Pre-Survey \\
Worked With & 2 \\
\hline Somali & 1 \\
Bolivian & 2 \\
Hispanic & 4 \\
North American & 1 \\
Peruvian & 1 \\
Russian & 1 \\
Taiwanese & \\
\hline
\end{tabular}

Comments on Working with the Somali Women

Only eight out of 22 women stated that their student had studied outside of their tutoring sessions. 
Table XXXIX. Tutor's student studied outside of tutoring sessions

\begin{tabular}{|lc|}
\hline $\begin{array}{l}\text { Tutor's Student Studied Outside of } \\
\text { Tutoring Sessions }\end{array}$ & Post-Survey \\
\hline Yes & 8 \\
No & 14 \\
\hline
\end{tabular}

Eleven of the tutors reported that they thought that their students had achieved their goals while ten stated that their Somali students did not achieve their goals.

Table XXXX. Tutor reports that her student achieved her goals

\begin{tabular}{|lc|}
\hline $\begin{array}{l}\text { Tutor Reports that Her Student } \\
\text { Achieved Her Goals }\end{array}$ & Post-Survey \\
\hline Yes & 11 \\
No & 10 \\
\hline
\end{tabular}

Tutors' Assessment of Lutheran Community Service Trainings

The scores of the post-survey indicate how the tutors considered the Lutheran Family Service trainings and entire program. The results of what the tutor thought about the English as a Second Language Training are that 10 tutors considered the training to be adequate. Eight of the North American participants did not find the training to be adequate.

Table XXXXI. Tutor thought that E.S.L. training was adequate

\begin{tabular}{|lc|}
\hline $\begin{array}{l}\text { Tutor Thought that the ESL Training } \\
\text { was Adequate }\end{array}$ & Post-Survey \\
\hline Yes & 10 \\
No & 8 \\
\hline
\end{tabular}


As for training on teaching literacy, 13 out of eighteen tutors found the training to be adequate and five were not satisfied.

Table XXXXII. Tutor thought that literacy training was adequate

\begin{tabular}{|lc|}
\hline Tutor Thought that Literacy & Post-Survey \\
Training was Adequate & 13 \\
\hline Yes & 5 \\
\hline
\end{tabular}

Twenty-two of 23 women found the cultural training about Somali culture to be adequate.

Table XXXXIII. Tutor thought that cultural training was adequate

\begin{tabular}{|lc|}
\hline Tutor Thought that Cultural & Post-Survey \\
Training was Adequate & \\
\hline Yes & 22 \\
No & 1 \\
\hline
\end{tabular}

Tutors' Assessment of the Total Tutoring Program

All of the 23 tutors agreed that they liked the program's cause.

Table XXXXIV. Tutor liked the program's cause

\begin{tabular}{|lc|}
\hline Tutor Liked the Program's & Post-Survey \\
Cause & 23 \\
\hline Yes & 0 \\
No & \\
\hline
\end{tabular}

However, only 18 out of twenty-three liked the program's content. 
Table XXXXV. Tutor liked the program's content

\begin{tabular}{|lc|}
\hline Tutor Liked the Program's & Post-Survey \\
Content & 18 \\
\hline Yes & 5 \\
\hline No & \\
\hline
\end{tabular}

Only nine of the 23 tutors wanted to continue tutoring on an official basis.

TableXXXXVI. Tutor wants to continue to be a tutor

\begin{tabular}{|lr|}
\hline $\begin{array}{l}\text { Tutor Wants to Continue to Be } \\
\text { a Tutor }\end{array}$ & Post-Survey \\
\hline Yes & 9 \\
No & 14 \\
\hline
\end{tabular}


The BEST Test Scores

TableXXXXVII. B.E.S.T. test scores

\begin{tabular}{|c|c|c|c|c|c|c|c|}
\hline $\begin{array}{l}\text { Participant } \\
\text { Identification } \\
\text { Number }\end{array}$ & $\begin{array}{l}\text { Number of } \\
\text { Tutoring } \\
\text { Hours } \\
\text { Completed }\end{array}$ & $\begin{array}{l}\text { BEST } \\
\text { Short } \\
\text { Form } \\
\text { Adjusted }\end{array}$ & $\begin{array}{l}\text { BEST } \\
\text { Long } \\
\text { Form } \\
\text { Score }\end{array}$ & $\begin{array}{l}\text { Change } \\
\text { in } \\
\text { Score }\end{array}$ & $\begin{array}{l}\text { BEST } \\
\text { Short } \\
\text { Form } \\
\text { Adjusted } \\
\text { Level }\end{array}$ & $\begin{array}{l}\text { BEST } \\
\text { Long } \\
\text { Form } \\
\text { Level }\end{array}$ & $\begin{array}{l}\text { Level } \\
\text { Change }\end{array}$ \\
\hline 102 & 53 hours & 18 & 42 & +24 & III & VII & +4 levels \\
\hline 104 & 42 hours & 17 & 42 & +8 & VII & VII & No change \\
\hline 106 & 20 hours & 18 & 52 & +34 & III & VII & +4 levels \\
\hline 107 & 49 hours & 20 & 32 & +12 & III & VI & +3 levels \\
\hline 108 & 52 hours & 64 & 76 & +13 & VII & VII & No change \\
\hline 109 & 51 hours & 41 & 57 & +16 & VII & VII & No change \\
\hline 120 & 51 hours & 41 & 48 & +7 & VII & VII & No change \\
\hline 130 & 24 hours & 26 & 28 & +2 & IV & V & +1 level \\
\hline 140 & 16 hours & 15 & 21 & +6 & II & III & +1 level \\
\hline 150 & 0 hours & 5 & 11 & +6 & 0 & I & +1 level \\
\hline 160 & 64 hours & 15 & 22 & +8 & II & III & +2 levels \\
\hline 170 & 56 hours & 57 & 68 & +11 & VII & VII & No change \\
\hline 180 & 64 hours & 41 & 64 & +23 & VII & VII & No change \\
\hline 190 & 56 hours & 13 & 16 & +3 & II & III & +1 level \\
\hline 200 & 12 hours & 55 & 58 & +3 & VII & VII & No change \\
\hline 210 & 72 hours & 70 & 76 & +6 & VII & VII & No change \\
\hline 220 & 42 hours & 34 & 57 & +23 & VII & VII & No change \\
\hline 230 & 22 hours & 66 & 71 & +5 & VII & VII & No change \\
\hline 240 & 72 hours & 18 & 26 & +8 & III & V & +2 levels \\
\hline 250 & 14 hours & 8 & 10 & +2 & II & II & No change \\
\hline 260 & 54 hours & 41 & 65 & +24 & VII & VII & No change \\
\hline 270 & 72 hours & 16 & 22 & +6 & III & III & No change \\
\hline 280 & 20 hours & 61 & 68 & +7 & VII & VII & No change \\
\hline 290 & 72 hours & 13 & 31 & +18 & II & VI & +4 levels \\
\hline 300 & 21 hours & 36 & 49 & +13 & VII & VII & No change \\
\hline 320 & 36 hours & 26 & 22 & -4 & IV & III & -1 level \\
\hline 330 & 62 hours & 27 & 48 & +21 & V & VII & +2 levels \\
\hline
\end{tabular}


Administration of the BEST Pre and Post-Tests

When educators think about giving oral tests, they usually visualize the test participants sitting at a table across from them in a quiet, well-lit and empty room. The test participants would be familiar with the process of taking tests. This was not the case for testing the Somali women. It was necessary to test the women in their homes because of childcare and transportation problems - two barriers that prevented the women from succeeding at previous English as a Second Language classes. Many of the Somali women had no or little experience with formal testing. They were very nervous and did not know what to expect. Sometimes it was necessary to give some positive prodding to get the women to take and continue the tests.

While this oral test was good for the Somali participants because it allowed them to demonstrate their knowledge of English without having to show any literacy skills, it was not always easy to administer in the homes of the women. The Short Form of the Best Test usually took less than ten minutes. When it was possible, the test administrator attempted to test the women in a quiet place of the home where they would not be distracted. This was almost an impossible goal to achieve. Most of the apartments that the women live in have a shared kitchen and living room space. Usually, the children would stay in the living room, and the testing was done in the kitchen at a table if the family had one. 
In every Somali's home, there were children present during the testing. The entire household tended to get excited with curiosity when the administrator came to the house. Children of different ages presented different challenges to testing. If the children were under five years old and there were no other older females to care for them in the household, they would do their best to get their mother's attention during the test. Some of the younger children cried, screamed or hurt other children to get attention. The children were curious about their visitor and they often tried to open the bag of blank tests and photos that the administrator commonly carried to the tests. The test administer discovered that it was beneficial to bring distracting objects for the children or help hold the children during the interviews. If the women had older children who could speak English, the problem of keeping the children from interfering with the testing process was a challenge. At one household, the administrator found that two children had fallen asleep on her lap by the time their mother had finished the test.

Since the BEST Short Form is an entirely oral test, the children could hear the questions and would try to tell their mothers the answer even if they were not in the same room. The test administrator learned that it was necessary to set ground rules with the older children before the testing began. Even if the children understood that the test was intended to test the level of their mother's English, the children were still tempted to aid their mother. They had the habit of speaking for their mother in English. 
The Best Test Scores and Levels can be used as predictors for job readiness. Subjects who obtain a level one or two are ready only for very routine entry-level jobs in which the tasks can be demonstrated easily and do not require communicating orally with others. A score that results in level three indicates that the subject is ready for a routine entry-level job that involves basic oral communication and in which all tasks can be demonstrated.

Level four subjects are prepared for entry-level jobs with simple oral communication. However, the tasks need to be demonstrated to the subject. People who obtain scores in the level five range can handle job and job training with simple oral and basic written instructions. The tasks still need to be demonstrated in-person in front of the subject. Subjects with scores that fit into level six or higher are prepared for jobs and job training with simple oral and written instructions and diagrams. Level seven and higher subjects can get jobs that include simple oral and written instructions in familiar and some unfamiliar situations.

The B.E.S.T. Test

Two of the questions on the BEST Short Form ask about time. One question requires the student to tell the time by reading a picture of a clock face on paper. The other questions inquire about the time the subject had gotten up in the morning. The subject is tested on her skills of reading time from a picture of a clock with hands. 
This question was difficult for most of the Somali women. When many saw the pictures of the round clocks with hands on them, they did not know how to read the time. They turned the picture of the clocks around and looked curiously at it from all angles. It appeared that they understood that the question was asking what time it was but they had no experience interpreting a picture of an old fashioned clock. They also had trouble telling time from digital clocks while taking the BEST Short Form. The combination of numbers seemed to confuse them.

One of the questions requires the subject to spell her name orally. Two of the questions ask the subject to formulate questions. Most of the Somali women could spell their first names easily, and many counted each letter of their name with their hands as they said them aloud as they answered. 
CHAPTER FIVE

Results

Lutheran Community Services designed The Somali Women's Program to Remove Barriers to Self-Sufficiency Project to provide 30 Somali women with 72 hours of volunteer E.S.L. tutoring. However, only 4 of the 28 Somali women remaining in the project received the full 72 hours of training. It is difficult to compare the scores of women who received varying amounts of tutoring.

The Somali Women's Program to Remove Barriers to Self-Sufficiency was one model for a literacy program to teach women how to read and write in English. It is important to look at what this model was able to deliver and what limited it from achieving all of the goals set in the detailed project description sent to the State of Oregon.

\section{The State of Oregon}

A representative from the State of Oregon, involved in monitoring the grant Lutheran Community Services received to assist the Somali women, stated that the state is not interested directly in the language achievement of each refugee woman. Rather, the State of Oregon wants to be assured that each grant is executed as it was written.

For the grant for the Somali women, the State of Oregon checked to see if Lutheran Community Services recruited the number of Somali participants and North American tutors that was stated in the grant proposal. In the grant, Lutheran 
Family Services stated they would refer a number of women to state employment services.

According to the State of Oregon, the program was successful because Lutheran Community Services completed all of the steps that were written in the initial grant proposal. However, this did not ensure that each woman received the 72 hours of tutoring that they were promised. The literature on evaluation strongly suggests that program evaluation should include the examination of a number of factors, not just the assessment of the execution of the steps outlined in a grant. Schalock and Thorton (1988) state that a program evaluation should include examination of the problem addressed, the persons served, the services provided, the evaluation context, the expected outcomes and the justification or rationale of the program (p.24). Crandall (1992) argues that an evaluation of an adult literacy program should involve the students themselves and tests that mirror real-life tasks. Alderson (1991) explains that consideration of the affective factors during testing is important. Brown and Pennington (1991) advocate for the use of interviews and questionnaires as integral parts of evaluation.

It is crucial to examine the reasons why the 72 -hour requirement was satisfied by only four tutors. The expectation of "four hours a week" of instruction was not realistic for most the Somali women who did not have much academic experience. Puchner (1977) advocates for having focus groups or obtaining input from the groups to be served before the program is organized. The Lutheran Community Services staff did have some of the women complete a survey before the 
program was set up. However, it is evident that the staff did not request the input of the group of women in general when they wrote the literacy grant proposal. It is possible that the Somali women would have expressed their reluctance to adhere to a four-hour a week requirement. Even if the tutors had enough energy and time to offer four hours, pre-literate and low-level learners of English become easily tired and distracted by their household duties after an hour. One tutor commented, "We had six sessions two times a week. This was too much. One hour and twenty minutes is as much as we can do with no interruptions."

Interruptions were common during the tutoring sessions in the Somali households. The fact that the women tutored at home was beneficial for the students but not for most of the tutors. It was difficult for the tutors if the children were present during the sessions. From Appendix G, it was apparent that they Somali women's children came to interrupt the tutoring every five minutes. While some of the tutors enjoyed interacting with the children, the distraction hurt the potential for the women's learning.

Lutheran Community Services have subsequently created a homework tutoring program for the children. One method to help the children and women obtain literacy skills at the same time is to create a family literacy program that promotes learning together.

The plans at the beginning of the program stated, "The ESL Coordinator and volunteer will develop an individualized study plan for each client." (Lutheran Community Services, 1999, p. 3). According to Auerbach, when the learners are 
directed towards study that relates to their lives, the students will learn more. When the program began, I observed that there was no needs assessment included in program, and I suggested that Lutheran Community Services create one. I offered one that I have used in several classes and adopted that for the Somali clients. Apparently these suggestions and needs indicated by the Somali women themselves were put aside once the tutoring began. Each tutor wrote a weekly report on what they had taught their Somali student. However, these logs, for the most part, were not used to assist each tutor in teaching methods and helping to help the tutor get appropriate teaching materials.

\section{Factors of Success}

One of the guiding research questions for this study was: "What factors lead to success in studying and acquiring foreign language for refugee women from Somalia who have no formal schooling or literacy training in their own language?" From this question, it was hypothesized that women who could read and write in Somali would acquire more English skills.

The ability to read and write was not tested by the investigator; the skills were reported by the Somali women themselves. Generally, the women who could read and write in Somali scored better on their English tests; however, there were some exceptions. Thirteen women reported that they could read and write in Somali. The Somali participant (\#106) who improved her B.E.S.T. Test score the most (34 points) did not read and write in Somali. Six of the seven women (\#130, \#250, \#190, 
$\# 230, \$ 140, \# 210$ and $\# 270$ ) who scored the least improvement (from 2-6 test points) reported that they could not read and write in Somali.

Another hypothesis created during the evaluation was that having print in English around the Somali women's house will help the Somali women learn more effectively.

The result was that eighteen reported that they have printed material in English including books, children's homework, bills and advertisements in their homes. However, having print in the homes did not appear to affect the improvement of the test scores compared with women who did not report having print in English in their homes.

\section{Test Results}

A guiding research question concerning employability was: "Can Somali women acquire enough English skills to be employable after receiving 72 hours of tutoring from non-professional ESL tutors?" Concerning employability, one hypothesis stated that some Somali students who receive 72 hours of tutoring would be able to fill out a simple form by the end of the program.

This is difficult to answer because only four women completed 72 hours of tutoring. The result was of the women who reported that they could fill out a job

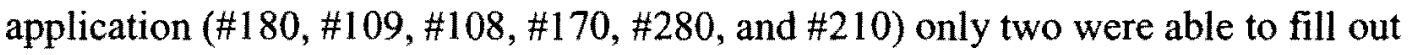
the application form perfectly.

Somali participant $\# 270$ achieved a mere improvement of 6 test points by the end of the program. She did not study outside of class and her tutor commented, 
"Her kids would do it (the homework) for her at the last minute." By the end of her tutoring sessions, \#270 stated that she could not write sentences in English, she could not speak on the phone in English and she could not fill out a job application in English. The only part of the application test that she was able to fill out was her name. Her self-reported reading level improved from beginning level to intermediate. However, this improvement is not enough to be employable.

Participant \#210 was able to fill out the test application before the tutoring began. On the first survey, she reported she was not able to fill out a job application, and after the 72 hours of tutoring she stated she could complete an application on her own. However, the tests indicate that she was able to write an application before she received instruction, and that her skills did not improve greatly due to the tutoring.

Participant \#240's test scores improved by 8 points. By the end of the program, \#240 was able to read in English after receiving tutoring however, she still could not fill out a job application, write sentences or speak on the phone in English. Therefore, \#240, also did not become employable by the end of the tutoring sessions. \#240 commented that she achieved the goals that she had set for herself. \#240 stated, "I learned to read, speak and write."

Participant \#290's final form test results demonstrated that she is not ready to be employed in the United States because she was only able to fill out her full name, street address (without giving the city, state or zip code), and her children's names (without the ages and genders.) At the end of the 72 hours of tutoring, she reported that she could not fill out a job application or speak on the phone in English. Her 
self-reported reading and writing skills improved. Her B.E.S.T. Test scores indicated that she jumped from Level II to Level VI. Unfortunately, this increase did not make her employable.

There are several reasons why it is difficult to prepare Somali women for employability in the United States. Even after receiving hours of English as a Second Language tutoring, some Somali women may never be ready to work in a new language outside of their homes. The factors that cause problems include Post Traumatic Stress Syndrome, pressures from the welfare system to become employed, problems with their children, being forced to move by the housing authority, trouble learning a new language due to age, not completing homework and low selfconfidence, and not having the experience learning how to read and write in their own language.

Other factors that were not clearly addressed by the Somali women's tutoring program at Lutheran Community Services include examining what additional skills are necessary to acquire for becoming prepared to function in the workplace outside the home. According to Seufort (1999), effective workers need to be able to "manage resources (time, money, materials, space, and staff); to manage information (acquiring and evaluating data, organizing and maintaining files, and interpreting and communicating information); interact socially (working on teams, teaching others, serving, leading, negotiating, and working in multicultural environments); understand systems (both organizational and technological, monitoring and 
correcting performance); and use technology (selecting and applying technology to specific tasks)" (Seufort, 1999, p. 3).

Examining the test scores of the form test, there was no Somali woman who could demonstrate great achievement in filling out application forms. Nine women who were not able to provide any information beginning in the form tests were able to at least write their full name on the second form test. Four women were unable to complete any part of the form correctly by the end of the program. Only 7 of the 28 Somali women indicated on the second survey that they could fill out a job application. Only one Somali woman, \#210 was able to complete the form perfectly.

\section{Influence of the Tutor's Background}

The influence of a tutor's background is significant to the study. The guiding research question concerning this was: "Does the background of a tutor determine the success of a Somali woman learning English?"

The corresponding hypothesis was that students who have tutors who have been to Africa, who have worked with refugees, and who have English as a Second Language teaching experience will achieve more success from the tutoring.

To examine this hypothesis, each tutor was asked in the first survey to indicate whether they had been to Africa, whether they had any experience working with or helping refugees or whether they had any English as a Second Language teaching experience.

The defining result was that the top three students who had improved their test scores by $24-34$ points each (\#102, \#260 and \#106) had tutors who had lived in 
Africa, who had prior experience with refugees and who had extensive English as a Second Language tutoring or teaching experience.

Having a tutor who with experience living or working in Africa appears to be a significant factor in student success. The tutors for the lowest five achieving students (B.E.S.T. Test scores improved 2-5 points) (\#130, \#250, \#190, \#200 and \#230) had never been to Africa, had no prior experience helping refugees and had no experience teaching English as a Second Language. In addition to the lowest five, the next seven lowest achieving women (\#130, \#250, \#190, \#200, \#223, \#230, \#140, $\# 210, \# 270, \# 280, \# 104$, and $\# 106)$, had tutors who had never been to Africa before.

One tutor commented that tutors should have training in basic linguistics if they are going to be good teachers. Tutor \#1501 stated:

I took a linguistics class last quarter at Portland State. I took basic linguistics. Wonderful, wonderful (teacher.) I was definitely intrigued. I didn't expect to like it. I think the training talking about culture and all that kind of stuff was kind of an exposure to this as kind of what to expect. But the basic of what linguistics is. It was really missing (from the training at the Somali Pathways Program.) You know, I mean I was sitting there just enthralled in class going oh my god you know that if you don't learn your grammar structure by the time you're three to five that you know that kind of stuff. And I went oh, no wonder I 'm having a difficult time with my student. She's wonderful. I like her. She likes me. Love the family. But know you I knew - I saw the handwriting on the wall. Almost if you're going to have people teaching ESL, I think they almost have to have that as a required class. 
Tutors'Perceptions

Materials and Curriculum.

Each tutor had a different opinion about the teaching materials. One tutor liked the materials because she found the lessons saved her from spending a lot of time preparing. Another said, "Laubach is boring. The vocabulary is limited." Many of the tutors obtained extra materials for their student at the library. One tutor created an entire curriculum tailored for her student, and some women purchased new materials for their Somali students to keep.

Lutheran Community Services hoped that the tutors would teach the women employment vocabulary and interviewing skills, but this did not occur. The tutors were not supplied with employment training materials. Many tutors did not want to concentrate on that type of vocabulary, and one commented that she did not realize that the goal was employment. She signed up to teach English to a Somali woman, not employment skills. They wanted to work with words that the women could use everyday.

Literacy Training

Thirteen tutors indicated that the literacy training was adequate, and five reported that it not useful for them because it did not directly help them with tutoring. In such a case, it would be good for a program to assess the quality of the training and offer more detailed and specific training in the mid-program. 
Cultural Training

The training that all but one tutor expressed as exceptional was the cultural training. This helped them to work with the women. It would have been useful to have offered another training; tutors were receptive and they indicated that they would enjoy attending another cultural training. Also, a second workshop could examine cultural and individual literacy issues at a deeper level after the tutors had some experience working with the Somali families and the women.

\section{Student Perceptions}

What the Somali students thought about their tutors could have an effect on their willingness to try to learn English. The researcher hypothesized that if the Somali women considered their tutors to be friends and good teachers, then they would learn more English. The result was that 27 Somali women answered that they thought of their tutors as friends and good teachers. Only 1 Somali participant refused to answer that survey question. Therefore, it is impossible to determine if the Somalis' perceptions of their tutors as good teachers and friends affected their test scores.

One Somali woman (\#130) indicated how disappointed she was when her tutor stopped coming to teach her, stating, "Now bad - no teacher - no good." Student \#230 said that her teacher was a good teacher and "she (the tutor) is a good person. She is helpful. She have job in her house. I will call. Everything I like she want to try to help me. \#210 said, "I like her (the tutor) and she is my best friend." \#160 said that she needed the constant help of her tutor and stated, "I wanted to 
(achieve goals) but I can't. When the teacher is here, I kind of know it but when she is gone, I can't hold on to it."

One student (\#170) showed her appreciation of her tutor's help when she said, "Sometimes she (the tutor) explains I don't know new vocabulary - new words. English program with one teacher is better because I stay in my home is problems for my children's problems. Every time I go to class, the place, the distance is far from my children. My teacher comes on time. I want to solve - on time is difficult for me - my children's problems."

Another student (108) said that her tutor had promised to continue to teach her even after the program was finished. \#108 said, "I want to learn more English. My teacher she never going, she never finish, she never, she never leave me. She said, 'I help you \#108, don't worry."'

Affective factors are very important to a student's chance of learning literacy skills effectively. The corresponding hypothesis was: Somali women who had a strong self-concept would achieve higher scores.

The results was that \#250 who only received a two-point test improvement stated with the help of an interpreter that she had a weak self-concept, did not achieve her goals and that, "I like my (tutoring) program but my brain doesn't work. I want to try anything but I can't do it. My brain doesn't work. I am a greatgrandmother. I took one year and I learned nothing."

Participant \#120 said about her own progress, "Me - no good. My teacher she's very good." 
Family support is important to a student's success. The researcher postulated that students who received encouragement to learn English from their family would achieve higher scores than those who did not.

Unfortunately, no clear answer for this hypothesis was reached. This was impossible to measure as all of the women indicated that their families supported their language learning efforts.

It was hypothesized that Somali women who reported studying at least one hour a day would achieve higher scores than those who did not. The results were that fifteen women reported that they studied more than one hour a day outside of the tutoring sessions. However, the fact that they reported studying more than one hour a day did not produce better test scores. The scores of the women who reported studying ranged from an advancement of 2 points to 24 points. The advancement of scores of the women who did not study ranged from 6 points to 34 points. One woman commented that, "I did not go to school in Somalia so I am not used to studying." It is interesting to note that only eight tutors stated that they thought their Somali students had studied more than one hour a day outside of the tutoring sessions.

It was hypothesized that students who reported that their tutors became their friends would achieve more improved scores. Twenty-two of 24 Somali women stated at the end of the program that they became friends with their tutors. With these results, it is not possible to test the hypothesis above. 


\section{Lutheran Community Services Staff Perceptions}

Lutheran Community Services staff considered the Somali program a success. They used a number of factors, and not just the Somali women's test scores to come to this conclusion. Some of the social-service related achievements they mentioned that could not be measured by tests included one woman obtaining her driving learner's permit, one Somali passing the United States Citizenship exam, many women dealing better with their depression and prescribed medications, and one woman received the medical attention and surgery she needed for her cataracts.

\section{Limitations of the Study}

\section{Participants}

There were several limitations to this study. The tutors and students who participated in the study were not randomly chosen. In addition, as Barretta (1986) states, to allow for generalization of the results, the number of participants must be large. The number Somali students studied in this evaluation is too small for generalizations.

\section{Cultural Factors}

The tests used in this study were created by academics from the United States. The B.E.S.T. Test had no pictures that the women could directly relate tonone of the people portrayed in the pictures were African. The pictures demonstrated typical settings found in a North American home. 
Lack of Test-Taking Experience

Requesting subjects who have not experienced a school setting or academic style testing before may have affected test results. Many of the Somali women had no formal experience writing a test and felt apprehensive about any type of testing.

\section{Interpretation}

The researcher did not speak the language of the subjects and had to rely on the assistance of a Somali interpreter. The researcher was not able to cross-check that the interpretation of the questions and answers of the tests, and that questionnaires were interpreted and exactly relayed as accurately as possible.

The Testing Atmosphere

Most all of the testing was done in the homes of the Somali women. This was the best place for the Somali women to be tested because they were not able to come to an independent testing center. However, their homes were not good environments for testing. Some of the problems the researcher and Somali encountered in the homes during testing included poor lighting, inadequate furniture (to be able to write comfortably), and interruptions due to the noise of the television and telephone. Also, many of the Somali women live in apartments adjacent to each other, and they frequently came to visit each other without notice. The largest threat to the validity of the testing was posed by the Somali women's children. The older children wanted to answer the test questions for their mothers and the younger children were very distracting during the tests. 


\section{Evaluation of Tutoring Programs}

The final research question is: How should English as Second Language programs be evaluated? For the Somali tutoring program, if the State of Oregon and Lutheran Community Services had only used the Somali women's pre and post-test scores to measure the success, then the program would have been deem a failure as the women did not show much improvement on paper. It is not possible to get the entire pictures of the program and the Somali women's achievements from test scores. However, from the student and tutor questionnaires, improvement in English and most importantly, improvement in the Somali women's self-concepts, are noted. The program did not make many of the Somali women employable. But the tutoring and interaction with their teachers allowed them to make the first step to feel some confidence about learning a new language and building relationships with women from another culture.

Receiving and evaluating on-going comments about the program from the participants is imperative. Cumming states, "Literacy programs that fail to act on the potential for language minority learners to shape and direct the nature of their programs, in their own terms, may be creating distinct barriers that exclude such learners from meaningful level of participation" (Cumming, 1992, p. 3). 


\section{Recommendations and Implications for the Field}

After listening to all of the stakeholders involved in this project, the following recommendations were crafted and are now provided for creators of future programs to help tutors with pre-literate or low-level English as a Second Language learners.

1. Provide tutors with basic phrase books and tapes in their tutor's languages. The terms should include basic ones used in teaching.

Often it is difficult for tutors to communicate their instructions clearly to beginning learners. If the students are not able to use the interpreting skills of other family members or children, they may not understand what the tutor would like them to do.

If the tutors are providing services in the student's home, knowing a few phrases in their student's language could help tutors relate to the student's family and community. It may also help them understand if the student is not present for tutoring.

2. Provide a cultural training for the students.

It is assumed that the refugees and immigrants who come to the United States will be able to function in society and understand how to survive in the culture. This includes understanding how to work with a tutor one-on-one. Refugees are usually given a short introduction and pamphlet in their own language explaining basic living skills such as going shopping and going to the doctor. Pre-literate students cannot use the pamphlet because they cannot read it. Several tutors mentioned how surprised they were that the Somali women were not able to complete basic tasks in the community even after living in the United States for a couple years. The tutors 
helped their students with these tasks. However, the tutors thought that introducing survival skills to the women was the job of the agency supporting the refugees, not the tutors.

The tutors also mentioned that the Somali women were not well-prepared to accept a tutor into their homes. As Puchner (1977) explained, the one-on-one tutor model comes from North American culture. Some of the Somali students may not have known how to set up for their tutors' visit because they did not have experience working with a tutor before. The tutors suggest that the agency prepare women for being tutored. This includes offering a quiet space in the home for the tutoring sessions, understanding that the tutors are volunteers and many have full-time employment and families to take care of, and understanding differences in educational practices. The tutors and program staff may have assumed that the Somali women would know how a North American tutor wanted to be treated in their homes. Appropriate cultural training would solve these programs in the future.

Understanding how the refugees' culture considers literacy training for females is also important. As Cumming (1992) explains, some groups of refugees do not consider it important for women to acquire literacy skills. In fact, receiving education challenges the basic beliefs of some cultures that women are meant to work only in their homes.

3. Have part of the budget allotted for creating language-learning materials suited for pre-literate people.

Several of the tutors reported they struggling with the tutoring materials provided to them or that they giving up using the materials all together. If some of a 
literacy program's budget is allocated for hiring literacy specialists to create materials specifically for the population served in the program, tutoring and learning could be easier.

4. Make the family part of the literacy plan.

The children in the Somali homes could speak English very well. They were used to helping their mothers function by interpreting for them. The children want to support their mothers and they do not want to their mothers to be embarrassed by their lack of language skills. This caused a major problem for the literacy and language testing during the evaluation because the children would try to answer for their mothers. One tutor commented that the weekly homework was always completed by the time she came to teach, but from the handwriting, she could see it was the daughter, not the Somali mother, was completing the work.

By creating a comprehensive literacy plan, the entire family can support each other while learning important skills. If the entire family is involved, the adult heads of households will feel comfortable spending time learning the new language because it is a participatory effort and not something that takes time away from family activities and chores.

5. Create materials the women could use everyday and create a list of "homework" suggestions that could be part of the women's daily lives.

Using English as a Second Language materials that do not relate to the women's immediate lives and responsibilities does not entice the women to study. It is better to provide materials that relate directly to the women's local surroundings. 
If the women see that the materials could be used while completing their everyday tasks in their city, they will be more apt to study them outside of tutoring sessions.

6. Put the literacy books in the public library close to the students so that the women could continue to learn on their own even if they could not afford textbooks.

If materials are available at libraries or schools close to them, the women will be able to learn English and other life skills independently if they choose to do so. If agencies deem employment as the most important subject the study, they can supply the library with employment-related instructional materials. By making the materials available at libraries, the women will feel that there is a deadline for looking at the material. If agencies give them the books directly, there is a possibility that the books will sit on tables or shelves in the homes without being used for extended periods of time.

7. Train tutors in basic phrases and linguistic structures of the languages of their students with orientation meetings, booklets and tapes.

It is important for the tutors to have a cursory sense of the structure of the language of the student. There are some sounds and sentence structures found in English that may not exist in the student's language. Knowledge of these differences can help tutors be better prepared to introduce their lessons effectively.

Even if the tutors are taught a few words of their student's language at the orientation, it is important for them to have materials to study on their own if they choose to do so. Giving the tutors small and simple phrase books with supplementary 
tapes or $\mathrm{CD}$ roms to help with pronunciation may help facilitate communication between the tutors and students.

8. Set clear and goals boundaries for the tutors to understand when they are working with refugees.

Program staff needs to have clear guidelines for what they would like their volunteers to do with their assigned students. They need to communicate this to the tutors during the orientation and in writing. If the goal of the program is to provide linguistic assistance, the tutors should be instructed to help as much with literacy exercises as much as they can and not worry about the other needs of their students. Literacy tutors can get burned out easily if they start to help the social service challenges the students encounter.

9. Be aware of tutors' linguistic abilities and assign them to students who may share a common language.

If there is a possibility that a tutor and a student may share a language, even one that is not the target language, they should be paired up. Especially if the student is preliterate, having a common way to communicate with aid them to learn faster.

10. Create a regular optional monthly support meeting for the tutors.

Tutors enjoy sharing their experiences and teaching ideas. Holding monthly optional tutoring meetings, will give the tutors an opportunity to learn from each other and share positive and frustrating tutoring session stories. Each tutor may not be able to attend each of the meetings, but by offering the meetings once a month, each tutor will have many chances to meet the other tutors and program staff. 
11. Create and maintain a tutoring website that includes lesson plans for pre-literate students, comments from tutors, students and staff and invite tutors to contribute to a listserve that would give tutors new teaching ideas and a place to share their experiences.

Not all tutors may be able to attend monthly meetings so by creating a tutor listserve and supporting website, the tutors will be able to communicate with each other. Also, by offering the information on the internet, other tutoring programs may benefit from the materials that the tutors and programs staff create for the preliterate students.

\section{Suggestions for Further Research}

Refugees come with more barriers to language learning than most students learning a foreign language. More studies about literacy programs for preliterate refugees and evaluation types for refugee programs are needed. Other types of research needed include:

1. More studies about the long-term language learning progress of refugees who come to the United States are needed. It is difficult to track this type of student but perhaps the caseworkers of the students rather than the short-term language centers could test the linguistic progress.

2. Studies of the cultural factors included in the tests used for students of basic English could determine how much language ability the instruments tested.

3. Studies on the effects of Post-Traumatic Stress Syndrome on the abilities of people to learn new languages. 
5. Research on the motivation factors to learn languages for female refuges residing with their grown children could aid tutors with such students. 


\section{REFERENCES}

Affholter, D. (1994). Outcome monitoring. Wholey, Joseph S., Hatry, Harry P., Newcomer, Kathryn E. (1994). Handbook of practical program evaluation. San Francisco: Jossey-Bass.

Africa watch. Retrieved 6/7/2000 from http://www.zmag.org/racewatch/africawatch.htm

Alderson, J. C. (1991). Language testing in the 1990's: how far have we come? how much further have we to go? In S. Anivan (Ed.), Current Developments in Language Testing. Anthology Series 25. Singapore: SEAMEO Regional Language Centre.

Auerbach, E. (1996). Adult esl/literacy from the community to the community: A guide book for participatory literacy training. Mahwah: Laurence Earlbaum Associates, Inc.

Baretta, A. (1994). Toward a methodology of e.s.l. program evaluation. TESOL Quarterly, 144-151.

Bhatia, T. (1983). Literacy in monolingual societies. Annual Review of Applied Linguistics, 4, 23-32.

Biber, D., \& Hared, M. (1991). Literacy in Somali: Linguistic consequences. Annual Review of Applied Linguistics, 12, 260-282.

Bickman, Leonard. (1987). Using program theory in evaluation. San Francisco: Jossey-Bass, Inc., Publishers.

Brown, D. \& Pennington, M. (1991). Developing Effective Evaluation Systems for Language Programs, 3-19. Pennington, P. Building Better English Language Programs. Washington D.C.: NAFSA: Association of International Educators.

Burt, M., \& Keenan, F. (1995). Adult E.S.L. learner assessment: purposes and tools. ERIC Digest. Retrieved 6/2/01 from http $\|$ www.cal.org/ncle/DIGEST/keenan.htm.

Catholic charities helps benadir clan resettle in Portland. (1996, July 18.) The Oregonian. p. $\mathrm{CO} 2$.

Crandall, J. A. (1992). Adult literacy development. Annual Review of Applied Linguistics, 12, 86-104. 
Cumming, A. (1992). Access to literacy for language minority adults. ERIC Digest. Retrieved 6/10/01 from http $\mid$ www.cal.org.ncle/DIGEST/cumming.html

Downing, J. (1973). Is literacy acquisition easier on some languages than in others? Visible Language, 7, 145-154.

Florez, M. (1998). Current concepts and terms in adult e.s.l. ERIC Digest. Retrieved 6/2/99 from www://cal.org/ncle/DIGEST/TERMSQA.htm.

International Organization for Migration. (1994). Current program for african refugees in kenya. (ERIC Reproduction Service No. ED407480.)

Kindell, G. (1993). Linguistics and literacy. Annual Review of Applied Linguistics, 8-15.

Laine, E. (1994). Emotional hindrances in the fl learning situation: the weak self-concept. (ERIC Document Reproduction Service No. ED343400)

Laine, E. (1989). The affective filter in foreign language learning and teaching. report 2: A validation study of filtering factors with a focus on the learner's fl self-concept. Jyvaskyla cross-language studies no. 15. (ERIC Document Reproduction Service No. ED303992)

Lutheran Community Services (1998). Confidential community women's survey. Portland, OR.

Long, M. (1984). Process and product in e.s.l. program evaluation. TESOL Quarterly, 18, 3, 409-425.

(1992) The B.E.S.T. Test. Kramer, J. \& Connoly, J.Mental measures yearbook. Lincoln: BUROS Institute of Mental Instruments.

Miller, T. (1994). Designing and conducting surveys. Wholey, Joseph S., Hatry, Harry P., Newcomer, Kathryn E. (1994). Handbook of practical program evaluation. San Francisco: Jossey-Bass.

Organization for Economic Co-operation and Development Human Resources Development Canada (1997). Literacy skills for knowledge society. Paris: Organization for Economic Co-operation and Development Human Resources Development Canada. 
Puchner, L. (1997). Family literacy in cultural context: lessons from two case studies. National Center on Adult Literacy. (ERIC Document Reproduction Service No. 412376)

Questions and Answers about The United States Refugee Resettlement Program (2000). Retrieved 5/7/2000 from http://www.cal.org/rsc/qa/qaeng.htm

Refugee resource center somalis refugee factsheet \#9 (2000). Retrieved 6/7/00 from http://www.cal.org/rsc/somali/shist.html

Schalock, R. \& Thornton, C. (1988). Program evaluation: a field guide for administrators. New York: Plenum Press.

Seufert, Peggy (1999). Refugees as English Language Learners: Issues and Concerns. ERIC Digest. Retrieved 6/11/01 from http $\backslash w w w . c a l . o r g . n c l e / D I G E S T /$ seufert.html

Somali social structure and gender roles (2001). Retrieved 5/6/01 from www.cal.org/rsc/somali/socialstuctureandgenterroles.html.

Stanovich, K. (1991). The psychology of reading: evolutionary and revolutionary developments. Annual Review of Applied Linguistics, 12. New York: Cambridge University Press.

World Book Map. Retrieved 7/8/01 from http://school.discovery.com/homework help/worldbook/atozpictures/mp00209.html 
APPENDIX A

CONSENT FORMS:

SOMALI WOMEN, NORTH AMERICAN TUTORS AND

LUTHERAN FAMILY SERVICE STAFF 


\section{Evaluation of the Somali Woman's Pathway to Self-Sufficiency Program}

This information for this evaluation will be used for Ann Kasper's master's thesis for the MATESOL program at Portland State University.

\section{Consent Form for Somali Speakers}

I, , agree to take part in this research project on the evaluation of the program. I understand that this study involves two surveys that will take from 5-10 minutes to complete. I will receive assistance from a Somali or Benadiri speaking interpreter if I wish. I will also take two English tests with oral and writing sections at the beginning and end of the program. These tests will take approximately 10 minutes to complete. If I am one of the four women in the study's subset, I understand that Ann Kasper will come to observe some of my tutoring sessions, take notes and record them. As part of that group, she will also come with an interpreter to ask me questions several times during the study.

Ann Kasper has told me that the purpose of the study is to learn how oneon-one tutoring helps women from Somalia learn English. I may not receive any direct benefit from taking part in this study, but the study may help to increase knowledge that may help others in the future. I may withdraw from this study at anytime without penalty.

Ann Kasper (phone number: $287-4124$ ) has offered to answer any questions I have about the study and what I am expected to do. She has promised that all information I give will be kept confidential to the extent permitted by law, and the names of all people in the study will be kept confidential. I understand that this project is completely for research and educational purposes and that I do not have to take part in this study, and that this will not affect my relationship with Lutheran Family Service or any government services including any financial assistance.

I have read (or have been read) and understand the above information and agree to take part in this study.

Date:

Signature:

Date:

Signature of Translator:

(Witness)

If you have concerns or problems about your participation in this study, please contact either the Human Subjects Research Review Committee, Office of Research and Sponsored Projects, 111 Cramer Hall, Portland State University, (503) 725-8182, or Ann Kasper at 628 N.E. Sacramento, Portland, OR 97212 or (503) 287-4124. 
Evaluation of the Somali Woman's Pathway to Self-Sufficiency Program

This information for this evaluation will be used for Ann Kasper's master's thesis for the MATESOL program at Portland State

University.

\section{Consent Form for the North American Tutors}

$\mathrm{I}$, , agree to take part in this

research project on the evaluation of the program. I understand that this study involves two surveys that each survey will take from 5-10 minutes to complete. If I am one of the four tutors in the subset study group, I agree to speak with Ann Kasper several times during the project. I also agree to let her observe me, take notes and record some of the tutoring sessions.

Ann Kasper has told me that the purpose of the study is to learn how effective one-on-one tutoring in English is for women from Somalia.

I may not receive any direct benefit from taking part in this study, but the study may help to increase knowledge that may help others in the future.

Ann Kasper (phone number: 287-4124) has offered to answer any questions I have about the study and what I am expected to do.

She has promised that all information I give will be kept confidential to the extent permitted by law, and the names of all people in the study will be kept confidential. I understand that I do not have to take part in this study, and that this will not affect my relationship with Lutheran Family Service and that I may withdraw from this study an anytime without any penalty. I have read and understand the above information and agree to take part in this study.

Date:

Signature:

Date:

Signature:

$$
\text { (Witness) }
$$

If you have concerns or problems about your participation in this study, please contact either the Human Subjects Research Review Committee, Office of Research and Sponsored Projects, 111 Cramer Hall, Portland State University, (503) 725-8182, or Ann Kasper at 628 N.E. Sacramento, Portland, OR 97212 or (503) 287-4124. 


\section{Evaluation of the Somali Woman's Pathway to Self-Sufficiency Program}

This information for this evaluation will be used for Ann Kasper's master's thesis for the MATESOL program at Portland State University.

\section{Consent Form for the Lutheran Family Service Staff}

I, , agree to take part in this research project on the evaluation of the program. I agree to speak with Ann Kasper several times during the project. Each interview will take approximately 15 minutes. I also agree to let her record the interviews.

Ann Kasper has told me that the purpose of the study is to learn how effective one-on-one tutoring in English is for women from Somalia.

I may not receive any direct benefit from taking part in this study, but the study may help to increase knowledge that may help others in the future.

Ann Kasper (phone number: 287-4124) has offered to answer any questions I have about the study and what I am expected to do.

She has promised that all information I give will be kept confidential to the extent permitted by law, and the names of all people in the study will be kept confidential. I understand that I do not have to take part in this study, and that this will not affect my relationship with Lutheran Family Service and that I may withdraw from this study at anytime without penalty.

I have read and understand the above information and agree to take part in this study.

Date:

Signature:

Date:

Signature:

$$
\text { (Witness) }
$$

If you have concerns or problems about your participation in this study, please contact either the Human Subjects Research Review Committee, Office of Research and Sponsored Projects, 111 Cramer Hall, Portland State University, (503) 725-8182, or Ann Kasper at 628 N.E. Sacramento, Portland, OR 97212 or (503) 287-4124. 
APPENDIX B

SURVEY INSTRUMENTS:

SOMALI WOMEN BEFORE AND AFTER PROGRAM AND

NORTH AMERICAN TUTORS BEFORE AND AFTER

PROGRAM 
Multicultural Community Services

Latheran Family Service

Name:

Date:

Survey Administrator:

Approximate Length of Administration:

\section{SURVEY I}

FOR SOMALI WOMEN

A. List five types of print that you look at each day (i.e. food labels, newspaper ads and children's homework)

1.

2.

3.

4.

5.

B. Please check the appropriate box.

AGREE DISAGREE

1. I think learning English will be difficult.

2. I am looking forward to meeting my tutor.

3. I studied English in a class in the United States. If agree, for how long?

Where?

4. I can read and write in Somali.

5. I can write the alphabet in English.

6. I can write sentences in English.

If agree, indicate:

Basic short sentences (3-5 words) or Long sentences (more than 5 words)

7. I can talk on the phone in English.

8. I can fill out a job application in English.

9. My family is encouraging me to learn English.

10. I plan to spend more than one hour a day to study what I learn.

C. My goals for learning English are:

D. Any other comments:

E. 
Multicultural Community Services

Lutheran Family Service

Name:

Date:

Survey Administrator:

Approximate Length of Administration:
SURVEY II

FOR SOMALI WOMEN

A. List the types of print that you read each day (i.e. food labels, newspaper ads and children's homework)

B. Please check the appropriate box.

AGREE DISAGREE

1. I achieved my goals in this program.

2. My goals were:

3. I can read in English.

4. If agree, indicate:

Beginning level (letters and numbers)

Intermediate level (short sentences)

Advanced level (simple books and forms)

5. I can write the alphabet in English.

6. I can write sentences in English.

7. If agree, indicate:

Basic short sentences (3-5 words) or

Long sentences (more than 5 words)

8. I can talk on the phone in English.

9. I can fill out a job application in English.

10. My family encouraged me to learn English.

11. I spent more than one hour day to study what I learned.

12. My tutor became my friend.

13. My tutor was a good teacher.

C. A follow-up program should include:

Any other comments: 
Multicultural Community Services

Lutheran Family Service

Name:

Date:

Survey Administrator:
SURVEY I

FOR TUTORS

Please check the appropriate box.

\section{AGREE DISAGREE}

1. I think teaching English will be difficult.

2. I have tutored or taught E.S.L. before.

3. If agree, who and what did you teach?

4.

5.

6. I feel comfortable entering a Somali household now.

7. I have worked with refugees before.

8. I can read and write in another language.

9. I feel comfortable with people who do not speak any English.

10. I have experience training someone how to fill out a job application.

11. I have traveled to Africa.

12. If agree, where?

13. For how long?

14. In what capacity?

15. I plan to spend more than one hour a day preparing lessons.

16. I hope that my tutee and I become friends.

Any other comments: 
Multicultural Community Services

Lutheran Family Service

Name:

Date:

Survey Administrator:
SURVEY II FOR TUTORS

A. Please check the appropriate box.

AGREE DISAGREE

11. Teaching English was difficult.

12. I feel comfortable with people who do not speak any English.

13. I received adequate E.S.L. and literary training.

14. I received adequate cultural training.

15. I received adequate support from the Lutheran Family Service staff.

16. I spent more than one hour a day preparing the lessons.

17. My tutee did homework and/or studied outside of our tutoring sessions.

18. My tutee achieved her goals.

19. I liked this program.

Why?

Suggestions for improvement:

20. My tutee and I became friends.

B. 1. I would like to continue as a tutor. yes no If yes, why?

2. I think that a follow-up program should include: 
APPENDIX C

LITERACY TEST FOR SOMALI WOMEN 
Name:

Date:

Administrator:

Time for Administration:

\section{Fill in the small letters.}

1. $\mathrm{a} \mathrm{b}_{\ldots} \ldots \ldots+\ldots \mathrm{m}_{-} \mathrm{p}_{-} \ldots \mathrm{t}_{-}$

$\overline{\text { Fill }}$ in the missing capital letters.

2. $\mathrm{A}_{-}{ }_{-}-\mathrm{G}_{-} \ldots-\mathrm{M}_{-} \mathrm{P}_{-}$

Fill in the form.

3.

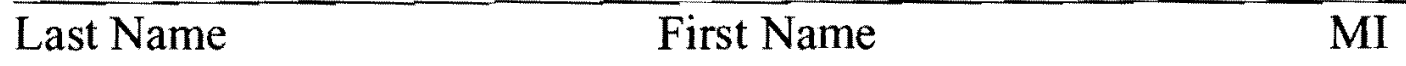

4.

Date of Birth

5.

Address City $\quad$ State $\overline{\text { Zip }}$

6. Phone Numbers:

Home

Work

Message

7. Household Size

8. Services received:

Stamps

AFDC/TANF _ _ Medicaid _ Food

9. Children's Names Sex

Age

10. Signature

Date 
APPENDIX D

\section{INDIVIDUAL TEST SCORES FOR SOMALI WOMEN}


Identification Name: 102

$102 \quad 1 / 3$

Tutoring Hours Completed: 53 hours, (74\% of 72 hours)

First Test: $\quad$ 9/19/99

Second Test: $\quad 6 / 30 / 00$

\begin{tabular}{|c|c|c|c|c|c|c|}
\hline & $\begin{array}{l}\text { BEST - } \\
\text { Short } \\
\text { Form } \\
\text { SCORE }\end{array}$ & $\begin{array}{l}\text { Total } \\
\text { Points } \\
\text { Possible }\end{array}$ & $\begin{array}{l}\text { BEST } \\
\text { Short } \\
\text { Form } \\
\text { Adjusted } \\
\text { SCORE }\end{array}$ & $\begin{array}{l}\text { BEST-Long } \\
\text { Form SCORE }\end{array}$ & $\begin{array}{l}\text { Total } \\
\text { Points } \\
\text { Possible }\end{array}$ & Changes \\
\hline Total & 9 & 40 & $18 \mathrm{III}$ & 42 VII & 91 & +24 \\
\hline Communication & 9 & 22 & --.------ & 30 & 48 & \\
\hline Fluency & 0 & 18 & - - - & 5 & 24 & \\
\hline Listening & $-\ldots$ & -------- & -------- & 7 & 11 & \\
\hline Reading/writing & - & - - - & - - - & 7 & 12 & \\
\hline Alphabet Test & 20 & 41 & --------- & 33 & 41 & $\begin{array}{l}\text { Improve, } \\
\text { write } \\
\text { small } \\
\text { and } \\
\text { capital } \\
\text { letters }\end{array}$ \\
\hline Form Test & Nothing & Perfect & --------- & $\begin{array}{l}\text { Partial-Full } \\
\text { name, child's } \\
\text { first name, } \\
\text { street address, } \\
\text { no city, state or } \\
\text { zip }\end{array}$ & Perfect & Improve \\
\hline
\end{tabular}

COMMENTS ON PARTICULAR TEST QUESTIONS

\begin{tabular}{|c|c|c|}
\hline & Before - BEST Short Form & After-BEST Long Form \\
\hline Greetings, Personal Information & 1. -5 . Half correct. & 1. -8 . One point missing. \\
\hline Describe Common Situation & 6. Home situation. & 9. -10 . \\
\hline Time/Numbers & 7. Tine. & 11. -13. Time recognition. \\
\hline & 8. Time get up perfect. & 14. Time get up perfect. \\
\hline Directions, Clarification & 9. -16. Cannot. & 15.-20. Cannot \\
\hline Money & 11. Recognizes money. & 25. -16 Knows money. \\
\hline Shopping, Food, Clothing & $\begin{array}{l}\text { 10. 12. Camnot ask for } \\
\text { prices. }\end{array}$ & $\begin{array}{l}27 .-28 . \text { Cannot ask for } \\
\text { prices. }\end{array}$ \\
\hline Signs & & $\begin{array}{l}\text { 29. }-32 \text {. Can read } 1 / 2 \text { of all } \\
\text { signs. }\end{array}$ \\
\hline $\begin{array}{l}\text { Emergencies, Safety Health, Body } \\
\text { Parts }\end{array}$ & 13. -1.5 & $\begin{array}{l}\text { 33. }-41 \text {. Answered in } \\
\text { Somali. }\end{array}$ \\
\hline Employment, Training & 18. & $\begin{array}{l}\text { 42. }-45 . \text { Answered in } \\
\text { Somali. "Easy in Somali." } \\
\text { Can identify jobs. }\end{array}$ \\
\hline
\end{tabular}




\author{
Alphabet \\ Before \\ Small: none \\ Capital: ABCDEFGHHIJKLMNOPQRSTU
}

$1022 / 3$

\section{LONG FORM}

46-49 Form -5 of 8 pts. Only date is correct

\section{After}

ALL PERFECT except "j" and "z" were backwards ABCD EHI"J"KL MNO PQURStUVWXY"Z" "J"and"Z" backwards

\begin{tabular}{|l|l|l|}
\hline \multicolumn{1}{|c|}{ Form } & After & RESULT \\
\hline 3. No full name. & 3. Full name. & + \\
\hline 4. No date of birth. & 4. No date of birth. & \\
\hline 5. No address & 5. Street address only. & \\
\hline 6. No phone number & 6. No phone number. & \\
\hline 7. No household size. & 7. No houschold size. & + \\
\hline 8. No information checked-oft. & 8. No infomnation checked-off: & \\
\hline 9. No chiluren's names, ages, sex. & 9. One child's name, no age, no sex. \\
\hline 10. No signature, date. & \\
\hline
\end{tabular}

\begin{tabular}{|c|c|c|}
\hline Survey One for Somali Women & Survey Two for Somali Women & Changes \\
\hline A. Print at home none & A. Print-none. & - \\
\hline $\begin{array}{l}\text { B. 1. Thinks learning English will } \\
\text { be not difficult. }\end{array}$ & $\begin{array}{l}\text { B. 1. Thinks learning English was not } \\
\text { difficult. }\end{array}$ & ++ \\
\hline $\begin{array}{l}\text { 2. Cannot read and write in } \\
\text { Somali. }\end{array}$ & 2. Cannot read and write in Somali. & \\
\hline 3. Cannot read in English. & 3. Can read in English -beginning level. & + \\
\hline $\begin{array}{l}\text { 4. Can write the alphabet in } \\
\text { English. }\end{array}$ & 4. Can write the alphabet in English. & ++ \\
\hline $\begin{array}{l}\text { 5. Cammot write sentences in } \\
\text { English. }\end{array}$ & 5. Cannot write sentences in English. & \\
\hline $\begin{array}{l}\text { 6. Cannot speak on the phone in } \\
\text { English. }\end{array}$ & 6. Cannot speak ou the phone in English. & \\
\hline $\begin{array}{l}\text { 7. Cannot fill out a job application } \\
\text { in English. }\end{array}$ & $\begin{array}{l}\text { 7. Cannot fill out a job application in } \\
\text { English. }\end{array}$ & \\
\hline $\begin{array}{l}\text { 8. Has family encouragement to } \\
\text { learn English. }\end{array}$ & $\begin{array}{l}\text { 8. Had family encouragement to learn } \\
\text { English. }\end{array}$ & ++ \\
\hline $\begin{array}{l}\text { 9. Plans to spend more than } 1 \text { hour } \\
\text { a day studying. }\end{array}$ & 9. Spent more than 1 hour a day studying. & ++ \\
\hline $\begin{array}{l}\text { 10. Looking forward to meeting } \\
\text { tutor. }\end{array}$ & 10. Tutor became a friend. & + \\
\hline $\begin{array}{l}\text { 11. Did not study English in the } \\
\text { US. }\end{array}$ & 11. Tutor was a good teacher. & + \\
\hline $\begin{array}{l}\text { C. Goals are "to communicate } \\
\text { with doctor, to shop, to use the } \\
\text { telephone and to talk with people at } \\
\text { school." }\end{array}$ & $\begin{array}{l}\text { 12. Did not achieve goals. "Not that much" } \\
\text { "i need more English. I want a tutor (not a } \\
\text { class.)? }\end{array}$ & - \\
\hline
\end{tabular}




\begin{tabular}{|c|c|c|}
\hline Survey One for Tutors & Survey Two for Tutors & Changes \\
\hline $\begin{array}{l}\text { 1. Thinks teaching English will bo } \\
\text { difficult. }\end{array}$ & 1. Teaching English was difficult. & \\
\hline $\begin{array}{l}\text { 2. Feels comfortable with people } \\
\text { who do not speak English. }\end{array}$ & $\begin{array}{l}\text { 2. Feels comfortable with people who do not } \\
\text { speak English. }\end{array}$ & \\
\hline $\begin{array}{l}\text { 3. Feels comfortable entering a } \\
\text { Somali household. }\end{array}$ & $\begin{array}{l}\text { 3. Feels comfortable entering a Somali } \\
\text { household. }\end{array}$ & \\
\hline $\begin{array}{l}\text { 4. Can read or write in another } \\
\text { language. }\end{array}$ & 4. Can read or write in another language. & \\
\hline $\begin{array}{l}\text { 5. Hopes to become friends with } \\
\text { student. }\end{array}$ & 5. Became friends with student. & \\
\hline $\begin{array}{l}\text { 6. Does not plans to spend more } \\
\text { that one hour a day preparing } \\
\text { lessons. }\end{array}$ & $\begin{array}{l}\text { 6. Did spend more than one hour a day } \\
\text { preparing lessons. }\end{array}$ & \\
\hline $\begin{array}{l}\text { 7. Has experience training } \\
\text { someone to fill out a job } \\
\text { application. }\end{array}$ & 7. Did not attend ESL training. & \\
\hline $\begin{array}{l}8 \text {. Has worked with refugees } \\
\text { before. }\end{array}$ & 8. Did not attend literacy teaching training. & \\
\hline 9. Has been to Africa. & 9. Cultural training at LFS was adequate. & \\
\hline \multirow{7}{*}{$\begin{array}{l}\text { 10. Has ESL tutoring experience - } \\
\text { "ESL in Taiwan for two years, } 2 \\
\text { classes at LFS in spring and } \\
\text { summer of 1998." }\end{array}$} & $\begin{array}{l}\text { 10. Received adequate support from LFS } \\
\text { staff. }\end{array}$ & \\
\hline & $\begin{array}{l}\text { 11. Student did not do homework outside of } \\
\text { tutering session. }\end{array}$ & - \\
\hline & 12. Student did achieve all of her goals. & + \\
\hline & 13. Liked the program's cause. & + \\
\hline & $\begin{array}{l}\text { 14. Liked the program's content. "I just } \\
\text { really enjoyed the one-on-one connection } \\
\text { with a woman. I didn't feel that there was } \\
\text { support from someone for materials and } \\
\text { those things. It made it comfortable to } \\
\text { continue." }\end{array}$ & + \\
\hline & $\begin{array}{l}\text { 15. Does not want to continue as a tutor. } \\
\text { "Basically because I'm liaving a baby. I } \\
\text { would do it again down the road. It's a timing } \\
\text { thing." }\end{array}$ & -- \\
\hline & $\begin{array}{l}\text { 16. Suggestions for other LFS } \\
\text { programs: "I think it would be good to } \\
\text { continue with the same kinds of ESL } \\
\text { training and also some of these women } \\
\text { seem to be open to learning new things } \\
\text { about being in the US and skills that } \\
\text { would help them getting around - they } \\
\text { need those kinds of classes to help them } \\
\text { assimilate." }\end{array}$ & \\
\hline
\end{tabular}


Identification Name: 104

Tutoring Hours Completed: 42 hours (58\% of 72 hours)

First Test: $\quad$ 9/19/99

Second Test: $\quad 7 / 1 / 00$

\begin{tabular}{|c|c|c|c|c|c|c|}
\hline & $\begin{array}{l}\frac{\text { BEST - }}{\text { Short Form }} \\
\text { SCORE }\end{array}$ & $\begin{array}{l}\text { Total } \\
\text { Points } \\
\text { Possible }\end{array}$ & $\begin{array}{l}\text { BEST } \\
\text { Short } \\
\text { Form } \\
\text { Adjusted } \\
\text { SCORE }\end{array}$ & $\begin{array}{l}\text { BEST-Long } \\
\frac{\text { Form }}{\text { SCORE }}\end{array}$ & $\begin{array}{l}\text { Total } \\
\text { Points } \\
\text { Possible }\end{array}$ & Changes \\
\hline Total & 17 & 40 & 34 VII & 42 VII & 91 & +8 \\
\hline Communication & 14 & 22 & --------- & 30 & 48 & \\
\hline Fluency & 3 & 18 & ---------- & 7 & 24 & \\
\hline Listening & - - & 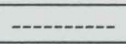 & --------- & 5 & 11 & \\
\hline Reading/writing & ------- & --------- & --------- & 7 & 12 & \\
\hline Alphabet Test & 29 & 41 & --------- & 33 & 41 & $\begin{array}{l}\text { Improve, } \\
+4\end{array}$ \\
\hline Form Test & $\begin{array}{l}\text { Perfect } \\
\text { except } \\
\text { missing } \\
\text { children's } \\
\text { ages and sex }\end{array}$ & Perfect & ---------- & $\begin{array}{l}\text { Missing } \\
\text { household } \\
\text { size, } \\
\text { information } \\
\text { checked off } \\
\text { and } \\
\text { children's } \\
\text { ages and sex }\end{array}$ & Perfect & $\begin{array}{l}\text { Slightly } \\
\text { worse }\end{array}$ \\
\hline
\end{tabular}

COMMENTS ON PARTICULAR TEST QUESTIONS

\begin{tabular}{|l|l|l|}
\hline & Before - BEST Short Form & After-BEST Long Form \\
\hline $\begin{array}{l}\text { Greetings, Personal } \\
\text { Information }\end{array}$ & 1. -5. Missing one. & 1.-8. Cannot spell. \\
\hline $\begin{array}{l}\text { Describe Common } \\
\text { Situation }\end{array}$ & 6. Home situation. & $9 .-10$. \\
\hline Time/Numbers & 7. Time. & 11. -13. Time recognition. \\
\hline & 8. Time get up perfect. & 14. Time get up. \\
\hline Directions, Clarification & $9,-16$. & $15 .-23$. \\
\hline Money & 11. Does recognize money. & $24 .-26$. Does know money. \\
\hline Shopping, Food, Clothing & $10,12$. Cannot ask for prices. & $27 .-28$. \\
\hline Signs & & $29 .-32$. Can read 3 of 4 signs. \\
\hline $\begin{array}{l}\text { Emergencies, Safety } \\
\text { Health, Body Parts }\end{array}$ & $13 .-15$. & $33,-41$. \\
\hline & 18. & $42 .-45$. \\
\hline Employment, Training & & \\
\hline
\end{tabular}




\section{LONG FORM}

46-49 Form -7 of 8pts. Address is missing the city, state and zip

\section{Before}

Small: abcdEFGHiJklmNopQRstuvwxyz Capital: AbcDEFGHiJKLMNOPQRSTUVWXYZ

\section{Form}

\begin{tabular}{|l|l|c|}
\hline Before & After & RESULT \\
\hline 3. Full name. & 3. Full name. & \\
\hline 4. No date of bitth. & 2. No date of birth. & + \\
\hline 5. Missing city and state & 5. Full address. & \\
\hline 6. Phone number. & 6. Phone number. & + \\
\hline 7. No houschold size. & 7. Household size. & + \\
\hline 8. No information checked- off. & 8. Information checked-off. & \\
\hline $\begin{array}{l}\text { 9. Children's names only, no ages, no } \\
\text { gender. }\end{array}$ & $\begin{array}{l}\text { 9. Children's names, no ages, no } \\
\text { sex. }\end{array}$ & \\
\hline 10. Signature and date. & $\begin{array}{l}\text { 10. Signature and date. } \\
\end{array}$ \\
\hline
\end{tabular}

\begin{tabular}{|c|c|c|}
\hline Survey One for Somali Women & Survey Two for Somali Women & Changes \\
\hline B. Print at home - none. & A. Print - children's books. & + \\
\hline $\begin{array}{l}\text { B. 1. Thinks learning English will be not } \\
\text { difficult. }\end{array}$ & $\begin{array}{l}\text { B. 1. Thinks learning English was } \\
\text { not difficult. }\end{array}$ & \\
\hline 2. Can read and write in Somali. & 2. Can read and write in Somali. & \\
\hline $\begin{array}{l}\text { 3. Can read in English -intermediate } \\
\text { level. }\end{array}$ & $\begin{array}{l}\text { 3. Can read in English -intermediate } \\
\text { level. }\end{array}$ & \\
\hline 4. Can write the alphabet in English. & $\begin{array}{l}\text { 4. Can write the alphabet in } \\
\text { English. }\end{array}$ & \\
\hline 5. Cannot write sentences in English. & $\begin{array}{l}\text { 5. Can write sentences in English - } \\
\text { basic sentences 3-5 words. }\end{array}$ & + \\
\hline 6. Cannot speak on the phone in English. & $\begin{array}{l}\text { 6. Can speak on the phone in } \\
\text { English. }\end{array}$ & + \\
\hline $\begin{array}{l}\text { 7. Cannot fill out a job application in } \\
\text { English. }\end{array}$ & $\begin{array}{l}\text { 7. Cannot fill out a job application } \\
\text { in English. }\end{array}$ & \\
\hline $\begin{array}{l}\text { 8. Has family encouragement to learn } \\
\text { English. }\end{array}$ & $\begin{array}{l}\text { 8. Had family encouragement to } \\
\text { learn English. }\end{array}$ & \\
\hline $\begin{array}{l}\text { 9. Plans to spend more than } 1 \text { hour a day } \\
\text { studying. }\end{array}$ & $\begin{array}{l}\text { 9. Spent more than } 1 \text { hour a day } \\
\text { studying. }\end{array}$ & + \\
\hline 10. Looking forward to meeting tutor. & 10. Tutor became a friend. & + \\
\hline $\begin{array}{l}\text { 11. Studied English in the US at Steps } \\
\text { for Success. }\end{array}$ & 11. Tutor was a good teacher. & + \\
\hline $\begin{array}{l}\text { C. Goals are "to be able to talk fluently, } \\
\text { talk with the doctor, at school, for } \\
\text { shopping and to get a better job." }\end{array}$ & $\begin{array}{l}\text { 12. Did achieve goals. "Yes, I } \\
\text { understand a little now. I understand } \\
\text { everything but when someone asks } \\
\text { me something, I start forgetting. I } \\
\text { would like to continue to study and } \\
\text { someone to help the children with } \\
\text { homework. I would like to learn } \\
\text { how to drive." }\end{array}$ & + \\
\hline
\end{tabular}

Alphabet

After

abcdefGHiJklmNopQrstuvwxyz

AbcDefGHiJKIMNOPQRStUVWXYZ 


\begin{tabular}{|c|c|c|}
\hline Survey One for Tutors & Survey Two for Tutors & Changes \\
\hline $\begin{array}{l}\text { 1. Thinks teaching English will be } \\
\text { difficult. }\end{array}$ & $\begin{array}{l}\text { 1. Teaching English was } \\
\text { difficult. }\end{array}$ & \\
\hline $\begin{array}{l}\text { 2. Feels comfortable with people who do } \\
\text { not speak English. }\end{array}$ & $\begin{array}{l}\text { 2. Feels comfortable with people } \\
\text { who do not speak English. }\end{array}$ & \\
\hline $\begin{array}{l}\text { 3. Feels comfortable entering a Somali } \\
\text { household. }\end{array}$ & $\begin{array}{l}\text { 3. Doesn't feel comfortable } \\
\text { entering a Somali household. }\end{array}$ & \\
\hline $\begin{array}{l}\text { 4. Cannot read or write in another } \\
\text { lanouage. }\end{array}$ & $\begin{array}{l}\text { 4. Cammot rend or write in another } \\
\text { languige. }\end{array}$ & \\
\hline 5. Hopes to become friends with student. & 5. Became friends with student. & + \\
\hline $\begin{array}{l}\text { 6. Does not plan to spend more thian one } \\
\text { hour a day preparing lessons. }\end{array}$ & $\begin{array}{l}\text { 6. Did spend more than one hour } \\
\text { a day preparing lessons. }\end{array}$ & - \\
\hline $\begin{array}{l}\text { 7. Has experience training someone to fill } \\
\text { out a job application. }\end{array}$ & $\begin{array}{l}\text { 7. EST training was not } \\
\text { adequate. }\end{array}$ & -- \\
\hline 8. Has not worked with refugees before. & $\begin{array}{l}\text { 8. Literacy teacling training from } \\
\text { LFS was not adequate. }\end{array}$ & -- \\
\hline 10. Has not been to Africa. & $\begin{array}{l}\text { 9. Cultural training at LFS was } \\
\text { adequate. }\end{array}$ & ++ \\
\hline \multirow[t]{7}{*}{ 10. Has no ESI tutoring experience: } & $\begin{array}{l}\text { 10. Received adequate support } \\
\text { from LFS staff. }\end{array}$ & ++ \\
\hline & $\begin{array}{l}\text { 11. Student did not do homework } \\
\text { outside of tutoring session. }\end{array}$ & - \\
\hline & $\begin{array}{l}\text { 12. Student did achieve her goals. } \\
\text { "As far as writing is concerned, } \\
\text { she improved a lot. She has good } \\
\text { spelling. Conversation makes her } \\
\text { nervous." }\end{array}$ & \\
\hline & $\begin{array}{l}\text { 13. Liked the program's cause. } \\
\text { "It's great to get them to be more } \\
\text { confident." }\end{array}$ & + \\
\hline & $\begin{array}{l}\text { 14. Liked the program's content. } \\
\text { "I didn't like the Laubach visuals. }\end{array}$ & + \\
\hline & $\begin{array}{l}\text { 15. Does want to continue as a } \\
\text { tutor. }\end{array}$ & + \\
\hline & $\begin{array}{l}\text { 16. Suggestions for other LFS } \\
\text { programs: "Make more events for } \\
\text { the women." Comments: } \\
\text { "They're very great families - a lot } \\
\text { of love and very disciplined." }\end{array}$ & \\
\hline
\end{tabular}


Identification Name: 106

$1061 / 3$

Tutoring Hours Completed: 20 hours (28\% of 72 hours)

First Test: $\quad 12 / 9 / 99$

Second Test: $\quad 6 / 13 / 00$

\begin{tabular}{|c|c|c|c|c|c|c|}
\hline & $\begin{array}{l}\frac{\text { BEST }-}{\text { Short }} \\
\frac{\text { Form }}{\text { SCORE }}\end{array}$ & $\begin{array}{l}\text { Total Points } \\
\text { Possible }\end{array}$ & $\begin{array}{l}\text { BEST } \\
\text { Short } \\
\text { Form } \\
\text { Adjusted } \\
\text { SCORE }\end{array}$ & $\begin{array}{l}\text { BEST-Long } \\
\text { Form } \\
\text { SCORE }\end{array}$ & $\begin{array}{l}\text { Total } \\
\text { Points } \\
\text { Possible }\end{array}$ & Changes \\
\hline Total & 9 & 40 & $18 \mathrm{III}$ & $52 \mathrm{VII}$ & 91 & +34 \\
\hline Communication & 6 & 22 & --------- & 28 & 48 & \\
\hline Fluency & 3 & 18 & - - & 16 & 24 & \\
\hline Listening & $\ldots$ & 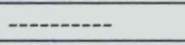 & - ---o--- & 8 & 11 & \\
\hline Reading/writing & $-\ldots$ & - -------- & 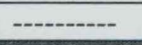 & 3 & 12 & \\
\hline & & & & & & \\
\hline Alphabet Test & 23 & 41 & - -.-- & 33 & 41 & +10 Improve \\
\hline Form Test & $\begin{array}{l}\text { Partial - } \\
\text { first } \\
\text { name, } \\
\text { street } \\
\text { number } \\
\text { and } \\
\text { "SW" } \\
\text { only }\end{array}$ & Perfect & --------- & $\begin{array}{l}\text { Better- } \\
\text { Full Name, } \\
\text { Address, } \\
\text { phone }\end{array}$ & Perfect & Improve \\
\hline
\end{tabular}

\section{COMMENTS ON PARTICULAR TEST QUESTIONS}

\begin{tabular}{|c|c|c|}
\hline & $\begin{array}{l}\text { Before - BEST Short } \\
\text { Form }\end{array}$ & After-BEST Long Form \\
\hline $\begin{array}{l}\text { Greetings, Personal } \\
\text { Information }\end{array}$ & $1,-5$ & 1. -8 \\
\hline $\begin{array}{l}\text { Describe Common } \\
\text { Situation }\end{array}$ & 6. Home situation. & 9. -10 \\
\hline Time/Numbers & 7. Time. & 11. -13 . Time recognition. \\
\hline & 8. Time get up. & 14. Time get up. \\
\hline $\begin{array}{l}\text { Directions, } \\
\text { Clarification }\end{array}$ & $9 .-16$. & $15 .-23$ \\
\hline Money & 11. Does not recognize & 24. -26. Does know money. \\
\hline $\begin{array}{l}\text { Shopping, Food, } \\
\text { Clothing }\end{array}$ & $\begin{array}{l}\text { 10., } 12 . \text { Can't ask for } \\
\text { prices }\end{array}$ & 27. -28. Can ask for prices. \\
\hline Signs & & 29. -32 . Can read 2 of 4 signs. \\
\hline $\begin{array}{l}\text { Emergencies, Safety } \\
\text { Health, Body Parts }\end{array}$ & 13. -15 & $33,-41$. \\
\hline $\begin{array}{l}\text { Employment, } \\
\text { Training }\end{array}$ & 18. & $42 .-45$ \\
\hline
\end{tabular}




\section{Before}

Small: ABCDEHiJKLMNOPQRSTUVWXYZ
ABCDEFGHIJKLMNOPQRSTUVWXYZ
46-49 Form -0 of 8 pts.

After

AbcdEFGHiJKLMNOPQRSTUV

Form

\begin{tabular}{|l|l|l|}
\hline Before & After & RESULT \\
\hline 3. First name only. & $\begin{array}{l}\text { 3. Full name. } \\
\text { 4. No date of birth. }\end{array}$ & + \\
\hline $\begin{array}{l}\text { 5. Street number and "SW" only for the date of birth. } \\
\text { address. }\end{array}$ & $\begin{array}{l}\text { 5. Street address, no city or state, } \\
\text { no zip. }\end{array}$ & \\
\hline $\begin{array}{l}\text { 6. No phone number: } \\
\text { 7. No household size. }\end{array}$ & \begin{tabular}{l} 
6. Phone number. \\
\hline 8. No information checked-off.
\end{tabular} & + \\
\hline $\begin{array}{l}\text { 9. No children's names, no ages, no } \\
\text { gender. No information checked-off: }\end{array}$ & \\
\hline 10. No signature, no date. & \begin{tabular}{l} 
no gender. \\
\hline
\end{tabular} & \\
\hline
\end{tabular}

\begin{tabular}{|c|c|c|}
\hline Survey One for Somali Women & Survey Two for Somali Women & Changes \\
\hline C. Print-none. & A. Print-none. & \\
\hline $\begin{array}{l}\text { B. 1. Thinks learning English will be } \\
\text { difficult. }\end{array}$ & $\begin{array}{l}\text { B. 1. Thinks learning English was } \\
\text { difficult. }\end{array}$ & \\
\hline 2. Cannot read and write in Somali. & $\begin{array}{l}\text { 2. Camot read and write in } \\
\text { Somali. }\end{array}$ & \\
\hline 3. Camnot roud in English. & $\begin{array}{l}\text { 3. Can read in English - beginning } \\
\text { level. }\end{array}$ & + \\
\hline 4. Can write the alphabet in English. & $\begin{array}{l}\text { 4. Can write the alphabet in } \\
\text { English. }\end{array}$ & \\
\hline 5. Cannot write sentences in English. & $\begin{array}{l}\text { 5. Can write sentences in English - } \\
\text { basic } 3-5 \text { word sentences. }\end{array}$ & + \\
\hline $\begin{array}{l}\text { 6. Camnot speak on the phone in } \\
\text { English. }\end{array}$ & $\begin{array}{l}\text { 6. Cannot speak on the phone in } \\
\text { English. }\end{array}$ & \\
\hline $\begin{array}{l}\text { 7. Cannot fill out a job application in } \\
\text { English. }\end{array}$ & $\begin{array}{l}\text { 7. Cannot fill out a job application } \\
\text { in English. }\end{array}$ & \\
\hline $\begin{array}{l}\text { 8. Has family encouragement to learn } \\
\text { English. }\end{array}$ & $\begin{array}{l}\text { 8. Had family encouragement to } \\
\text { learn English. }\end{array}$ & \\
\hline $\begin{array}{l}\text { 9. Plans to spend more than } 1 \text { hour a } \\
\text { day studying. }\end{array}$ & $\begin{array}{l}\text { 9. Did not spend more than } 1 \text { hoil } \\
\text { a day studying }\end{array}$ & - \\
\hline 10. Looking forward to meeting tutor. & 10. Tutor became a friend. & \\
\hline $\begin{array}{l}\text { 11. Studied English in the US at IRCO } \\
\text { for } 1 \text { month. }\end{array}$ & 11. Tutor was a good teacher. & \\
\hline C. Goals. & 12. Did not achieve goals. & - \\
\hline
\end{tabular}




\begin{tabular}{|c|c|c|}
\hline Survey One for Tutors & Survey Two for Tutors & Changes \\
\hline $\begin{array}{l}\text { 1. Thinks teaching English will not be } \\
\text { difficult: }\end{array}$ & 1. Teaching English was difficult. & - \\
\hline $\begin{array}{l}\text { 2. Feels comfortable with people who } \\
\text { do not speak English. }\end{array}$ & $\begin{array}{l}\text { 2. Feels comfortable with people who do } \\
\text { not speak English. }\end{array}$ & \\
\hline $\begin{array}{l}\text { 3. Feels comfortable entering a Somali } \\
\text { household. }\end{array}$ & $\begin{array}{l}\text { 3. Feels comfortable entering a Somali } \\
\text { household. }\end{array}$ & \\
\hline $\begin{array}{l}\text { 4. Can read or write in another } \\
\text { language. }\end{array}$ & 4. Can read or write in another language. & \\
\hline $\begin{array}{l}\text { 5. Hopes to become friends with } \\
\text { student. }\end{array}$ & 5. Became friends with student. & + \\
\hline $\begin{array}{l}\text { 6. Does not plan to spend more thail } \\
\text { one hour a day preparing lessons. }\end{array}$ & $\begin{array}{l}\text { 6. Did not spend more than one hour a } \\
\text { day preparing lessons. }\end{array}$ & \\
\hline $\begin{array}{l}\text { 7. Does have experience training } \\
\text { someone to fill out a job application. }\end{array}$ & 8. ESL training was adequate. & ++ \\
\hline 8. Has worked with refugees before. & $\begin{array}{l}\text { 8. Literacy teaching training from LFS } \\
\text { was adequate "I wish I had - learning } \\
\text { would - more tools for teaching colors, } \\
\text { basic verbs, how to use the bus." }\end{array}$ & ++ \\
\hline 9. Has been to Africa. & 9. Cultural training at LFS was adequate. & ++ \\
\hline \multirow[t]{7}{*}{ 10. Has ESL tutoring experience. } & $\begin{array}{l}\text { 10. Received adequate support from LFS } \\
\text { staff. }\end{array}$ & ++ \\
\hline & $\begin{array}{l}\text { 11. Student did homework outside of } \\
\text { tutoring session. }\end{array}$ & + \\
\hline & $\begin{array}{l}\text { 12. Student did not achieve hor goals. "We } \\
\text { didn't get far" }\end{array}$ & - \\
\hline & $\begin{array}{l}\text { 13. Liked the program's cause. "I believe } \\
\text { as a nation, we do not know about other } \\
\text { countries." }\end{array}$ & ++ \\
\hline & $\begin{array}{l}\text { 14. Did like the program's content. "I } \\
\text { appreciated them - I also made } \\
\text { flashcards." }\end{array}$ & ++ \\
\hline & 15. Wants to continue as a tutor. & ++ \\
\hline & $\begin{array}{l}\text { 16. Suggestions for other LFS programs: } \\
\text { "They should provide activities - survival } \\
\text { skills - how to use a telephone, calendar, } \\
\text { how to use basic things. They should } \\
\text { continue an open-door policy. Our world } \\
\text { is so much more complex." }\end{array}$ & \\
\hline
\end{tabular}


Identification Name: 107

Tutoring Hours Completed: 49 hours ( $68 \%$ of 72 hours)

First Test: $\quad$ 9/19/99

Second Test: $\quad 7 / 31 / 00$

\begin{tabular}{|c|c|c|c|c|c|c|}
\hline & $\begin{array}{l}\text { BEST -Short } \\
\text { Form } \\
\text { SCORE }\end{array}$ & $\begin{array}{l}\text { Total } \\
\text { Points } \\
\text { Possible }\end{array}$ & $\begin{array}{l}\text { BEST } \\
\text { Short } \\
\text { Form } \\
\text { Adjusted } \\
\text { SCORE }\end{array}$ & $\begin{array}{l}\frac{\text { BEST- }}{\text { Long }} \\
\text { Form } \\
\text { SCORE } \\
\end{array}$ & $\begin{array}{l}\text { Total } \\
\text { Points } \\
\text { Possible }\end{array}$ & Changes \\
\hline Total & 10 & 40 & $20 \mathrm{III}$ & 32 VI & 91 & +12 \\
\hline Communication & 8 & 22 & --.------ & 24 & 48 & \\
\hline Fluency & 2 & 18 & ---------- & 5 & 24 & \\
\hline Listening & 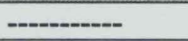 & 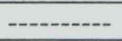 & 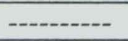 & 3 & 11 & \\
\hline Reading/writing & - - & - ------ & 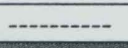 & 3 & 12 & \\
\hline Alphabet Test & 0 & 41 & ------- & 4 & 41 & Improve \\
\hline Form Test & Nothing & Perfect & ---------- & Nothing & Perfect & $\begin{array}{l}\text { Remains } \\
\text { empty }\end{array}$ \\
\hline
\end{tabular}

\section{COMMENTS ON PARTICULAR TEST QUESTIONS}

\begin{tabular}{|c|c|c|}
\hline & $\begin{array}{l}\text { Before - BEST Short } \\
\text { Form }\end{array}$ & After-BEST Long Form \\
\hline $\begin{array}{l}\text { Greetings, Personal } \\
\text { Information }\end{array}$ & $\begin{array}{l}\text { 1. }-5 . \text { One point } \\
\text { missing. }\end{array}$ & 1. -8 . Two points missing. \\
\hline $\begin{array}{l}\text { Describe Common } \\
\text { Situation }\end{array}$ & 6. Home situation. & $9 .-10$ \\
\hline Time/Numbers & 7. Time. & 11. -13 . Time recognition. \\
\hline & $\begin{array}{l}\text { 8. Time get up } \\
\text { perfect. }\end{array}$ & 14. Time get up perfect. \\
\hline Directions, Clarification & 9.-16. Cannot. & 15. -24. Cannot. \\
\hline Money & $\begin{array}{l}\text { 11. Recognizes } \\
\text { money. }\end{array}$ & 23. -26. Knows money. \\
\hline Shopping, Food, Clothing & $\begin{array}{l}10,12 . \text { Cannot ask } \\
\text { for prices. }\end{array}$ & 27. -28. Camnot ask for prices. \\
\hline Signs & & 29. -32. Can read $1 / 2$ of all signs \\
\hline $\begin{array}{l}\text { Emergencies, Safety } \\
\text { Health, Body Parts }\end{array}$ & $\begin{array}{l}\text { 13, }-15 . \text { Rreceived one } \\
\text { point ouly. }\end{array}$ & 33. -41 . \\
\hline Employment, Training & 18. & 42. -45 . Half. \\
\hline
\end{tabular}

LONG FORM

46-49 Form -1 of 8pts. Wrote first name only. 


\section{Alphabet \\ Before}

Small: abBS

Capital: ----------

Form

\section{Before}

3. No name.

4. No date of birth.

5. No address:

6. No phone number

7. No houschold size

8. No informaiton checked-off.

9. No children's names only, no ages, no

gender.

10. No signature, no date
After

$\mathrm{ABCD}$

\begin{tabular}{|c|c|c|}
\hline Survey One for Somali Women & Survey Two for Somali Women & Changes \\
\hline A. Print - none & A. Print- nove. & \\
\hline $\begin{array}{l}\text { B. 1. Thinks learning English will be } \\
\text { difficult. }\end{array}$ & B. 1. Thinks learning English was difficult. & \\
\hline 2. Cannot read and write in Somali. & 2. Cannot read and write in Somali. & \\
\hline 3. Cannot read in English. & 3. Can read in English - beginning level. & + \\
\hline $\begin{array}{l}\text { 4. Cannot write the alphabet in } \\
\text { English. }\end{array}$ & 4. Can write the alphabet in English. & + \\
\hline 5. Cannot write sentelices in English. & $\begin{array}{l}\text { 5. Can write sentences in English - basic } \\
\text { sentences 3-5 words. }\end{array}$ & + \\
\hline $\begin{array}{l}\text { 6. Cannot speak on the phone in } \\
\text { 15nglish. }\end{array}$ & 6. Cannot speak on the phone in English. & \\
\hline $\begin{array}{l}\text { 7. Cannot fill out a job application in } \\
\text { English. }\end{array}$ & $\begin{array}{l}\text { 7. Cannot fill out a job application in } \\
\text { English. }\end{array}$ & \\
\hline $\begin{array}{l}\text { 8. Has family encouragement to learn } \\
\text { English. }\end{array}$ & $\begin{array}{l}\text { 8. Had family encouragement to learn } \\
\text { English. }\end{array}$ & \\
\hline $\begin{array}{l}\text { 9. Plans to spend more than } 1 \text { hour a } \\
\text { day studying. }\end{array}$ & $\begin{array}{l}\text { 9. Did not spend more than } 1 \text { hour a day } \\
\text { studying. }\end{array}$ & - \\
\hline 10. Looking forward to meeting tutor. & 10. Tutor became a friend. & \\
\hline $\begin{array}{l}\text { 11. Studied English at IRCO for two } \\
\text { months. }\end{array}$ & 11. Tutor was a good teacher. & \\
\hline $\begin{array}{l}\text { C. Goals are "to be able to interpret } \\
\text { for other people (English to Somali.)" }\end{array}$ & 12. Did not achieve goals. & \\
\hline
\end{tabular}

\section{After}

4. No date of birth.

5. No address:

6. No phone number

7. No household size

8. No information checked off.

9. No chitdren's names, no ages, no sex

10. No signature, no date

\begin{tabular}{|l|}
\hline RESULT \\
\hline \\
\hline \\
\hline
\end{tabular}




\begin{tabular}{|c|c|c|}
\hline Survey One for Tutors & Survey Two for Tutors & Changes \\
\hline $\begin{array}{l}\text { 1. Thinks teaching English will } \\
\text { be difficult. }\end{array}$ & 1. Teaching English was not difficult. & + \\
\hline $\begin{array}{l}\text { 2. Does not feel eomfortable } \\
\text { with people who do not speak } \\
\text { English. }\end{array}$ & $\begin{array}{l}\text { 2. Feels comfortable with people who } \\
\text { do not speak English. }\end{array}$ & + \\
\hline $\begin{array}{l}\text { 3. Does not feel comfortable } \\
\text { entering a Somali household. }\end{array}$ & $\begin{array}{l}\text { 3. Feels comfortable entering a Somali } \\
\text { household. }\end{array}$ & + \\
\hline $\begin{array}{l}\text { 4. Cannot read of write in } \\
\text { another language. }\end{array}$ & $\begin{array}{l}\text { 4. Cannot read or write in another } \\
\text { languago. }\end{array}$ & + \\
\hline $\begin{array}{l}\text { 5. Hopes to become friends with } \\
\text { student. }\end{array}$ & 5. Became friends with student. & + \\
\hline $\begin{array}{l}\text { 6. Plans to spend more than one } \\
\text { hour a day preparing lessons. }\end{array}$ & $\begin{array}{l}\text { 6. Did not spend more than one hout a } \\
\text { day preparing lessons. }\end{array}$ & - \\
\hline $\begin{array}{l}\text { 7. Does not have experience } \\
\text { training someone to fill out a job } \\
\text { application. }\end{array}$ & $\begin{array}{l}\text { 9. ESL training at LFS was } \\
\text { adequate. }\end{array}$ & \\
\hline $\begin{array}{l}8 \text {. Has worked with refugees } \\
\text { before. }\end{array}$ & $\begin{array}{l}\text { 8. Literacy training at LFS was } \\
\text { adequate. }\end{array}$ & \\
\hline 11. Has not been to Africa. & $\begin{array}{l}\text { 9. Cultural training at LFS was } \\
\text { adequate. }\end{array}$ & \\
\hline \multirow{7}{*}{$\begin{array}{l}\text { 10. Has ESL tutoring } \\
\text { experience - "Children with } \\
\text { special needs." }\end{array}$} & $\begin{array}{l}\text { 10. Received adequate support from } \\
\text { LFS staff. }\end{array}$ & \\
\hline & $\begin{array}{l}\text { 11. Student studied outside of tutoring } \\
\text { session -"citizenship." }\end{array}$ & + \\
\hline & $\begin{array}{l}\text { 12. Student achieved all of her goals. } \\
\text { "She became a citizen." }\end{array}$ & + \\
\hline & $\begin{array}{l}\text { 13. Liked the program's cause. "Very } \\
\text { much." }\end{array}$ & + \\
\hline & $\begin{array}{l}\text { 14. Did not like the program's content } \\
\text { "User-friendly for the." }\end{array}$ & - \\
\hline & 15. Wants to continue as a tutor. & + \\
\hline & $\begin{array}{l}\text { 16. No suggestions for other LFS } \\
\text { programs. }\end{array}$ & \\
\hline
\end{tabular}


Identification Name: 108

$1081 / 3$

Tutoring Hours Completed: 52 hours (72\% of 72 hours)

First Test: $\quad 10 / 29 / 99$

Final Test: $\quad 6 / 21 / 00$

\begin{tabular}{|c|c|c|c|c|c|c|}
\hline & $\begin{array}{l}\text { BEST - } \\
\text { Short Form } \\
\text { SCORE }\end{array}$ & $\begin{array}{l}\text { Total } \\
\text { Points } \\
\text { Possible }\end{array}$ & $\begin{array}{l}\text { BEST } \\
\text { Short } \\
\text { Form } \\
\text { Adjusted } \\
\text { SCORE }\end{array}$ & $\begin{array}{l}\text { BEST-Long } \\
\text { Form } \\
\text { SCORE }\end{array}$ & $\begin{array}{l}\text { Total } \\
\text { Points } \\
\text { Possible }\end{array}$ & Changes \\
\hline Total & 33 & 40 & $64 V I I$ & 76 VII & 91 & +13 \\
\hline Communication & 18 & 22 & --------- & 46 & 48 & \\
\hline Fluency & 15 & 18 & - - - - - - --- & 21 & 24 & \\
\hline Listening & - & --------- & ---------- & 9 & 11 & \\
\hline Reading/writing & - & --------- & --------- & 8 & 8 & \\
\hline Alphabet Test & 8 & 41 & ---------- & 37 & 41 & $\begin{array}{l}\text { Improved! } \\
\text { wrote } \\
\text { small and } \\
\text { capital } \\
\text { letters }\end{array}$ \\
\hline Form Test & $\begin{array}{l}\text { Partial - } \\
\text { only } \\
\text { missing } \\
\text { household } \\
\text { size, child's } \\
\text { name, sex } \\
\text { and age }\end{array}$ & Perfect & --------- & $\begin{array}{l}\text { Partial only } \\
\text {-Missing } \\
\text { household } \\
\text { size, child's } \\
\text { sex and age }\end{array}$ & Perfect & Improve \\
\hline
\end{tabular}

\section{COMMENTS ON PARTICULAR TEST QUESTIONS}

\begin{tabular}{|l|l|l|}
\hline & Before - BEST Short Form & After-BEST Long Form \\
\hline $\begin{array}{l}\text { Greetings, Personal } \\
\text { Information }\end{array}$ & $1 .-5$. & $1 .-8$. \\
\hline $\begin{array}{l}\text { Describe Common } \\
\text { Situation }\end{array}$ & 6. Home situation. & $9 .-10$. \\
\hline Time/Numbers & T. Time. & \\
\hline & 8. Time get up perfect. & $11 .-13$. Time recognition. \\
\hline Directions, Clarification & $9 .-16$. & $15 .-23$ \\
\hline Money & 11. Does recognize money. & $23 .-26$. \\
\hline Shopping, Food, Clothing & $10 ., 12$. & $27 .-28$. \\
\hline Signs & & $29 .-32$. Can read 2 of 4 signs. \\
\hline $\begin{array}{l}\text { Emergencies, Safety } \\
\text { Health, Body Parts }\end{array}$ & $13 .-15$. One wrong. & $33 .-41$. \\
\hline & 18. & $42 .-45$. \\
\hline Employment, Training & & \\
\hline
\end{tabular}


LONG FORM

\section{Alphabet}

Before

Small:

abcdfhinmokrstwxyz

46-49 Form - 8/8pts.

Capital: abcdefGhijkl,mopQrstuwxyz ABCDEFGHIJKLMNOPQRSTUWXYZ

Form

\begin{tabular}{|l|l|l|}
\hline Before & After & RESULT \\
\hline 3. Full name. & 3. Full name. & \\
\hline 4. No date of birth. & 4. Date of birth. & + \\
\hline 5. Full address. & 5. Full address. & \\
\hline 6. Full phone number. & 6. Full phone number. & \\
\hline 7. No household size. & 7. No household size. & \\
\hline 8. Services checked. & 8. Services checked. & \\
\hline 9. No child's name or info. & 9. One child's name, no age or sex. & \\
\hline 10. Signature and date. & & \\
\hline
\end{tabular}

\begin{tabular}{|c|c|c|}
\hline Survey One for Somali Women & Survey Two for Somali Women & Changes \\
\hline A. Print - none. & A. Print - books, magazines. & \\
\hline $\begin{array}{l}\text { B. 1. Thinks learning English will } \\
\text { be difficult. }\end{array}$ & B. 1. Thinks learning English was difficult. & \\
\hline 2. Can read and write in Somali. & 2. Can read and write in Somali. & \\
\hline $\begin{array}{l}\text { 3. Can read in English - beginning } \\
\text { level. }\end{array}$ & 3. Can read in English - advanced level. & + \\
\hline $\begin{array}{l}\text { 4. Can write the alphabet in } \\
\text { English. }\end{array}$ & 4. Can write the alphabet in English. & \\
\hline $\begin{array}{l}\text { 5. Can write sentences in English - } \\
\text { intermediate level. }\end{array}$ & $\begin{array}{l}\text { 5. Can write sentences in English - long - more } \\
\text { than } 5 \text { words. }\end{array}$ & + \\
\hline $\begin{array}{l}\text { 6. Can speak on the phone in } \\
\text { English. }\end{array}$ & 6. Can speak on the phone in English. & \\
\hline $\begin{array}{l}\text { 7. Can fill out a job application in } \\
\text { English -"half." }\end{array}$ & 7. Can fill out a job application in English. & \\
\hline $\begin{array}{l}\text { 8. Has family encouragement to } \\
\text { learn English. }\end{array}$ & 8. Had family encouragement to learn English. & \\
\hline $\begin{array}{l}\text { 9. Plans to spend more than } 1 \text { hour } \\
\text { a day studying. }\end{array}$ & 9. Did spend more than 1 hour a day studying. & \\
\hline $\begin{array}{l}\text { 10. Looking forward to meeting } \\
\text { tutor. }\end{array}$ & 10. Tutor became a friend. & + \\
\hline $\begin{array}{l}\text { 11. Studied English for } 2 \text { years and } \\
6 \text { months at PCC. }\end{array}$ & 11. Tutor was a good teacher. & \\
\hline $\begin{array}{l}\text { C. Goals are "To understand, write, } \\
\text { read, to be able to communicate } \\
\text { with doctor." }\end{array}$ & $\begin{array}{l}\text { 12. Achieved goals. "Yes, when I go to the } \\
\text { doctor now, I can go along, my doctor she } \\
\text { understand me. Now I can call for appointment. } \\
\text { I want to learn more English. My teacher she } \\
\text { never going, she never finish, she never, she } \\
\text { never leave me. She said, 'I help you 108, don't } \\
\text { worry.' " }\end{array}$ & + \\
\hline
\end{tabular}




\begin{tabular}{|c|c|c|}
\hline Survey One for Tutors & Survey Two for Tutors & Changes \\
\hline $\begin{array}{l}\text { 1. Thinks teaching English } \\
\text { will be difficult. }\end{array}$ & $\begin{array}{l}\text { 1. Teaching English was } \\
\text { difficult. }\end{array}$ & + \\
\hline $\begin{array}{l}\text { 2. Feels comfortable with } \\
\text { people who do not speak } \\
\text { English. }\end{array}$ & $\begin{array}{l}\text { 2. Does not leel comfortable } \\
\text { with people who do not } \\
\text { speak English. }\end{array}$ & - \\
\hline $\begin{array}{l}\text { 3. Feels comfortable } \\
\text { entering a Somali household. }\end{array}$ & $\begin{array}{l}\text { 3. Feels comfortable } \\
\text { entering a Somali household. }\end{array}$ & + \\
\hline $\begin{array}{l}\text { 4. Caunol read or write in } \\
\text { another language. }\end{array}$ & $\begin{array}{l}\text { 4. Cannot read or write in } \\
\text { another language. }\end{array}$ & + \\
\hline $\begin{array}{l}\text { 5. Hopes to become friends } \\
\text { with student. }\end{array}$ & $\begin{array}{l}\text { 5. Became friends with } \\
\text { student. }\end{array}$ & + \\
\hline $\begin{array}{l}\text { 6. Plans to spend more than } \\
\text { one hour a day preparing } \\
\text { lessons. }\end{array}$ & $\begin{array}{l}\text { 6. Did not spend more than } \\
\text { one hour a day preparing } \\
\text { lessons. }\end{array}$ & + \\
\hline $\begin{array}{l}\text { 7. Does not have experience } \\
\text { training someone to fill out a } \\
\text { job application. }\end{array}$ & $\begin{array}{l}\text { 10. ESI training at ILS } \\
\text { was not adequate. }\end{array}$ & \\
\hline $\begin{array}{l}\text { 8. Has not worked with } \\
\text { refugees before. }\end{array}$ & $\begin{array}{l}\text { 8. Literacy training at LFS } \\
\text { was not adequate. }\end{array}$ & \\
\hline 12. Has not been to Africa. & $\begin{array}{l}\text { 9. Cultural training at LFS } \\
\text { was adequate. }\end{array}$ & \\
\hline \multirow{7}{*}{$\begin{array}{l}\text { 10. Has ESL tutoring } \\
\text { experience "Primarily as a } \\
\text { teacher - some one-on-one } \\
\text { with preparing lesson plans. }\end{array}$} & $\begin{array}{l}\text { 10. Received adequate } \\
\text { support from LFS staff. }\end{array}$ & \\
\hline & $\begin{array}{l}\text { 11. Student did not study } \\
\text { outside of tutoring session. }\end{array}$ & - \\
\hline & $\begin{array}{l}\text { 12. Student did not achieve } \\
\text { all of her goals. }\end{array}$ & - \\
\hline & $\begin{array}{l}\text { 13. Liked the program's } \\
\text { cause. }\end{array}$ & + \\
\hline & $\begin{array}{l}\text { 14. Did not like the } \\
\text { progran's content. }\end{array}$ & - \\
\hline & $\begin{array}{l}\text { 15. Wants to continue as a } \\
\text { tutor. }\end{array}$ & + \\
\hline & $\begin{array}{l}\text { 16. No suggestions for other } \\
\text { LFS programs. Comments: } \\
\text { "The Challenge Series was a } \\
\text { problem. She couldn't seem } \\
\text { to remember those words. I } \\
\text { want to make sure that the } \\
\text { little guy is all right. She } \\
\text { wants to go further. It would } \\
\text { have been good to have a } \\
\text { Somali-English dictionary. } \\
\text { She had trouble with long } \\
\text { vowels." }\end{array}$ & \\
\hline
\end{tabular}


Identification Name: 109

Tutoring Hours Completed: 51 hours (71\% of 72 hours)

First Test: 10/2/99

Second Test: $8 / 4 / 00$

\begin{tabular}{|c|c|c|c|c|c|c|}
\hline & $\begin{array}{l}\text { BEST -Short } \\
\text { Form } \\
\text { SCORE }\end{array}$ & $\begin{array}{l}\text { Total } \\
\text { Points } \\
\text { Possible }\end{array}$ & $\begin{array}{l}\text { BEST } \\
\text { Short } \\
\text { Form } \\
\text { Adjusted } \\
\text { SCORE }\end{array}$ & $\begin{array}{l}\text { BEST-Long } \\
\text { Form } \\
\text { SCORE }\end{array}$ & $\begin{array}{l}\text { Total } \\
\text { Points } \\
\text { Possible }\end{array}$ & Changes \\
\hline Total & 22 & 40 & $41 V I I$ & 57 VII & 91 & +16 \\
\hline Communication & 13 & 22 & - --o--- & 36 & 48 & \\
\hline Fluency & 9 & 18 & - ---o---- & 15 & 24 & \\
\hline Listening & - & - -.-.-n & - -.on-n-- & 6 & 11 & \\
\hline Reading/writing & - & --------- & ---------- & 9 & 8 & \\
\hline Alphabet Test & 4 & 41 & -------- & 8 & 41 & $\begin{array}{l}\text { Improve } \\
d+4\end{array}$ \\
\hline Form Test & $\begin{array}{l}\text { Partial-full } \\
\text { name, full } \\
\text { address and } \\
\text { phone } \\
\text { number }\end{array}$ & Perfect & ---------- & $\begin{array}{l}\text { Partial - full } \\
\text { name, } \\
\text { address and } \\
\text { phone } \\
\text { number }\end{array}$ & Perfect & \\
\hline
\end{tabular}

\section{COMMENTS ON PARTICULAR TEST QUESTIONS}

\section{Before - BEST Short Form}

1-5 All correct

6. "What are the children doing?" $1 / 2$ pts.

7. "What time is it?" $1 / 2$ pts.

8.-14. perfect answers

9. 0pts. Cannot formulate question for post office

10. Answered, "What question could he ask?

$1 \mathrm{pt} . / 2 \mathrm{pts}$.

12. perfect - explain shopping

13. What do you think happened? $3 / 3$ pts.

14. 0 pts.

15. "How do you think he feels?" $0 / 2$ pts.

16. Good -asked for clarification

17. "Do you think that the child was wrong?

18. "Which job would you like?" 0pts.

\section{After-BEST Long Form}

1-9 perfect

11-14 time - perfect answers

15. What question could she ask?" $1 / 2$ pts. 16.-28. perfect

41. "Do you think that the child was Why/Why Not?" 0 pts. wrong? Why/Why Not?" 0 pts.

31 Order" and "Don't Walk"-32 Couldn't read "Out of order."

33-54 Perfect. (except 41) 
LONG FORM

\begin{tabular}{|c|c|c|}
\hline $\begin{array}{l}\text { Before } \\
\text { Small: } \quad \text { abcdi } \\
\text { Capital: ABGMPQrSYZ } \\
\text { Form }\end{array}$ & After & \\
\hline Before & After & RESULT \\
\hline 3. Full name. & 3. Full name. & \\
\hline 4. No date of birth. & 4. Date of birth. & + \\
\hline 5. Full address. & 5. Full address. & \\
\hline 6. Full phone number. & 6. Full phone number. & \\
\hline 7. No household size: & 7. No houseliald size & \\
\hline 8. No services checked. & 8. Services checked. & \\
\hline 9. No child's namo or info. & 9. Child's name, no age or sex. & + \\
\hline 10. No signature and date. & 10. Signature and date. & \\
\hline
\end{tabular}

\begin{tabular}{|c|c|c|}
\hline Survey One for Somali Women & Survey Two for Somali Women & Changes \\
\hline A. Print none & A. Print none: & \\
\hline $\begin{array}{l}\text { B. 1. Thinks learning English will } \\
\text { be difficult. }\end{array}$ & $\begin{array}{l}\text { B. 1. Thinks learning English was } \\
\text { difficult. }\end{array}$ & \\
\hline 2. Can read and write in Somali. & 2. Can read and write in Somali. & \\
\hline $\begin{array}{l}\text { 3. Can read in English - beginning } \\
\text { level. }\end{array}$ & $\begin{array}{l}\text { 3. Can read in English - advanced } \\
\text { level. }\end{array}$ & + \\
\hline $\begin{array}{l}\text { 4. Can write the alphabet in } \\
\text { English. }\end{array}$ & 4. Can write the alphabet in English. & \\
\hline $\begin{array}{l}\text { 5. Can write sentences in English } \\
\text { - basic level. }\end{array}$ & $\begin{array}{l}\text { 5. Can write sentences in English - } \\
\text { long - more than } 5 \text { words. }\end{array}$ & + \\
\hline $\begin{array}{l}\text { 6. Cammot speak on the phone in } \\
\text { English. }\end{array}$ & 6. Can speak on the phone in English. & \\
\hline $\begin{array}{l}\text { 7. Cannot fill out a job application } \\
\text { in English. }\end{array}$ & $\begin{array}{l}\text { 7. Can fill out a job application in } \\
\text { English. }\end{array}$ & \\
\hline $\begin{array}{l}\text { 8. Has family encouragement to } \\
\text { learn English. }\end{array}$ & $\begin{array}{l}\text { 8. Had family encouragement to learn } \\
\text { English. }\end{array}$ & \\
\hline $\begin{array}{l}\text { 9. Plans to spend more than } 1 \\
\text { hour a day studying. }\end{array}$ & $\begin{array}{l}\text { 9. Did spend more than } 1 \text { hour a day } \\
\text { studying. - }\end{array}$ & \\
\hline $\begin{array}{l}\text { 10. Looking forward to meeting } \\
\text { tutor. }\end{array}$ & 10. Tutor became a friend. & \\
\hline $\begin{array}{l}\text { 11. Studied English for } 4 \text { months } \\
\text { at PCC. }\end{array}$ & 11. Tutor was a good teacher. & \\
\hline $\begin{array}{l}\text { C. Goals are "To be able to } \\
\text { communicate with teachers and } \\
\text { doctors." }\end{array}$ & 12. Achieved goals. & + \\
\hline
\end{tabular}


$1093 / 3$

\begin{tabular}{|c|c|c|}
\hline Survey One for Tutors & Survey Two for Tutors & Changes \\
\hline $\begin{array}{l}\text { 1. Thinks teaching English will } \\
\text { be difficult. }\end{array}$ & 1. Teaching English was not difficult. & + \\
\hline $\begin{array}{l}\text { 2. Does not feel comfortable with } \\
\text { people who do not speak English. }\end{array}$ & $\begin{array}{l}\text { 2. Feels comfortable with people who do not } \\
\text { speak English. }\end{array}$ & + \\
\hline $\begin{array}{l}\text { 3. Does not fecl comfortable } \\
\text { entering a Somali household. }\end{array}$ & $\begin{array}{l}\text { 3. Feels comfortable entering a Somali } \\
\text { household. }\end{array}$ & + \\
\hline $\begin{array}{l}\text { 4. Cammot read or write in another } \\
\text { language. }\end{array}$ & 4. Cannot read or write in another language: & \\
\hline $\begin{array}{l}\text { 5. Hopes to become friends with } \\
\text { student. }\end{array}$ & 5. Became friends with student. & + \\
\hline $\begin{array}{l}\text { 6. Plans to spend more than one } \\
\text { hour a day preparing lessons. }\end{array}$ & $\begin{array}{l}\text { 6. Did not spend more than one hour a day } \\
\text { preparng lessons. }\end{array}$ & - \\
\hline $\begin{array}{l}\text { 7. Does not have experience } \\
\text { training someone to fill out a job } \\
\text { application. }\end{array}$ & 7. ESL training at LFS was adequate. & \\
\hline $\begin{array}{l}8 . \text { Has worked with refugees } \\
\text { before. }\end{array}$ & 8. Literacy training at LFS was adequate. & \\
\hline 9. Has not been to Africa. & 9. Cultural training at LFS was adequate. & \\
\hline \multirow[t]{7}{*}{$\begin{array}{l}\text { 10. Has ESL tutoring experience } \\
\text { - "Children with special needs." }\end{array}$} & 10. Received adequate support from LFS staff. & \\
\hline & $\begin{array}{l}\text { 11. Student studied outside of tutoring session. - } \\
\text { "citizenship." }\end{array}$ & + \\
\hline & $\begin{array}{l}\text { 12. Student achieved all of her goals. "She } \\
\text { became a citizen." }\end{array}$ & + \\
\hline & 13. Liked the program's cause. "Very much." & + \\
\hline & $\begin{array}{l}\text { 14. Did not like the program's content "I needed } \\
\text { something more user-friendly for me." }\end{array}$ & - \\
\hline & 15. Wants to continue as a tutor. & - \\
\hline & 16. No suggestions for other LFS programs. & \\
\hline
\end{tabular}


Identification Name: 120

Tutoring Hours Completed: 51 hours $(71 \%$ of 72 hours

First Test: $\quad$ 9/19/99

Second Test: $\quad 8 / 4 / 00$

\begin{tabular}{|c|c|c|c|c|c|c|}
\hline & $\begin{array}{l}\text { BEST -Short } \\
\text { Form } \\
\text { SCORE }\end{array}$ & $\begin{array}{l}\text { Total } \\
\text { Points } \\
\text { Possible }\end{array}$ & $\begin{array}{l}\text { BEST } \\
\text { Short } \\
\text { Form } \\
\text { Adjusted } \\
\text { SCORE }\end{array}$ & $\begin{array}{l}\text { BEST-Long } \\
\text { Form SCORE }\end{array}$ & $\begin{array}{l}\text { Total } \\
\text { Points } \\
\text { Possible }\end{array}$ & Changes \\
\hline Total & 22 & 40 & $4 I V I I$ & 57 VII & 91 & +16 \\
\hline Communication & 17 & 22 & -----o-- & 36 & 48 & \\
\hline Fluency & 5 & 18 & --------- & 15 & 24 & \\
\hline Listening & ---n-- & ---------- & ---------- & 6 & 11 & \\
\hline Reading/writing & - --a- & - -------- & --------- & 9 & 12 & \\
\hline Alphabet Test & 20 & 41 & ---------- & 26 & 41 & $\begin{array}{l}+6 \\
\text { Improve }\end{array}$ \\
\hline Form Test & $\begin{array}{l}\text { Partial, No } \\
\text { Name, year } \\
\text { of Date of } \\
\text { Birth only, } \\
\text { no street on } \\
\text { address, } \\
\text { listed only } \\
\text { two children, } \\
\text { signed first } \\
\text { name with } \\
\text { date }\end{array}$ & Perfect & -------- & $\begin{array}{l}\text { Good, Full } \\
\text { name, wrong } \\
\text { Date of Birth, } \\
\text { Full address } \\
\text { "Bortland", } \\
\text { phone } \\
\text { number, four } \\
\text { children's } \\
\text { names, first } \\
\text { name } \\
\text { signature, } \\
\text { date }\end{array}$ & Perfect & Improve \\
\hline
\end{tabular}

COMMENTS ON PARTICULAR TEST QUESTIONS

\begin{tabular}{|c|c|c|}
\hline & $\begin{array}{l}\text { Before - BEST Short } \\
\text { Form }\end{array}$ & After-BEST Long Form \\
\hline $\begin{array}{l}\text { Greetings, Personal } \\
\text { Information }\end{array}$ & 1. -5 . One missing. & 1. -8 . \\
\hline Describe Common Situation & 6. Home situation. & 9. -10 \\
\hline Time/Numbers & 7. Time. & 11. -13. Time recognition. \\
\hline & 8. Time get up perfect. & 14. Time get up perfect. \\
\hline Directions, Clarification & $\begin{array}{l}\text { 9.16. Cannot make } \\
\text { question. }\end{array}$ & 15. -20. Cannot. \\
\hline Money & 11. Does notknow moncy. & 25. -16 Does not know money. \\
\hline Shopping, Food, Clothing & 10., 12. Can ask for prices. & 27. -28 . \\
\hline Signs & & 29. -32 . Can read all signs. \\
\hline $\begin{array}{l}\text { Emergencies, Safety Health, } \\
\text { Body Parts }\end{array}$ & $13,-15$ & 33. -41 . \\
\hline Employment, Training & 18. & $\begin{array}{l}\text { 42. }-45 \text {. "This job - because it is } \\
\text { easy." }\end{array}$ \\
\hline
\end{tabular}




\section{LONG FORM}

46-49 Form

-5 of 8pts. Address is missing the city, state and zip, signature is the first name only, date is good

Before

Alphabet

Small: absdeFJhoQrsmnMpQrstuFwxys

\section{After}

abCDEFGHIKLMmoqprstuvwsyz

Capital: ABCDEFJiHKMCDPORSWEXSWYL ABCDEFGHIGKLMOPQRSTUVWSYZ

\section{Form}

\begin{tabular}{|c|c|c|}
\hline Before & After & RESULT \\
\hline 3. No name. & 3. Full name. & + \\
\hline 4. Date of birth. & 4. Today's date. & - \\
\hline $\begin{array}{l}\text { 5. House number, city, state and zip - no } \\
\text { street on the address. }\end{array}$ & $\begin{array}{l}\text { 5. House number, street, city, state and zip - } \\
\text { "Bortland" }\end{array}$ & \\
\hline 6. Phone number. & 6. Phone number. & \\
\hline 7. No household size: & 7. Household size. & \\
\hline 8. No informalion checked-ofl: & $\begin{array}{l}\text { 8. Information not checked off - put numbers } \\
\text { on the places for checking. }\end{array}$ & \\
\hline $\begin{array}{l}\text { 9. Two children's names, no ages, no } \\
\text { gender. }\end{array}$ & $\begin{array}{l}\text { 9. Five children's names, age for one child } \\
\text { only, no gender. }\end{array}$ & + better \\
\hline 10. Signature (first name only), date. & 10. Signature (first name only), date. & \\
\hline
\end{tabular}

\begin{tabular}{|c|c|c|}
\hline Survey One for Somali Women & Survey Two for Somali Women & Changes \\
\hline A. Print - newspaper, homework. & A. Print-none. & \\
\hline $\begin{array}{l}\text { B. 1. Thinks learning English will be } \\
\text { difficult. }\end{array}$ & B. 1. Thinks learning English was difficult. & \\
\hline 2. Can read and write in Somali. & 2. Can read and write in Somali. & \\
\hline $\begin{array}{l}\text { 3. Can read in English - beginning } \\
\text { level. }\end{array}$ & 3. Can read in English. & \\
\hline 4. Can write the alphabet in English. & 4. Can write the alphabet in English. & \\
\hline 5. Cannot write sentences in English. & $\begin{array}{l}\text { 5. Can write sentences in English - long } \\
\text { sentences - more than } 5 \text { words. }\end{array}$ & + \\
\hline $\begin{array}{l}\text { 6. Camnot speak on the phone in } \\
\text { English. }\end{array}$ & 6. Can speak on the phone in English. & + \\
\hline $\begin{array}{l}\text { 7. Camnot fill out a job application in } \\
\text { English. }\end{array}$ & 7. Can fill out a job application in English. & + \\
\hline $\begin{array}{l}\text { 8. Has family encouragement to learn } \\
\text { English. }\end{array}$ & 8. Had family encouragement to learn English. & \\
\hline $\begin{array}{l}\text { 9. Plans to spend more than } 1 \text { hour a day } \\
\text { studying. }\end{array}$ & $\begin{array}{l}\text { 9. Did not spend more and I hour a day } \\
\text { studying - also with TV. }\end{array}$ & + \\
\hline 10. Looking forward to meeting tutor. & 10. Tutor became a friend. & ++ \\
\hline $\begin{array}{l}\text { 11. Studied English in the US at PCC } \\
\text { and Steps for Success for } 4 \text { months. }\end{array}$ & 11. Tutor was a good teacher. & ++ \\
\hline $\begin{array}{l}\text { C. Goals are "to be able to read, write, } \\
\text { speak." }\end{array}$ & $\begin{array}{l}\text { 12. Did not achieve goals. "Coals were to read } \\
\text { better and eating. Me - no good. My teacher - } \\
\text { she's very good:" "Need more Einglish. Need a } \\
\text { class." }\end{array}$ & - \\
\hline
\end{tabular}




\begin{tabular}{|c|c|c|}
\hline Survey One for Tutors & Survey Two for Tutors & Changes \\
\hline 1. Thinks teaching English will not be difficult. & 1. Teaching English was difficult: & - \\
\hline $\begin{array}{l}\text { 2. Feels comfortable with people who do not } \\
\text { speak English. }\end{array}$ & $\begin{array}{l}\text { 2. Feels comfortable with people who } \\
\text { do not speak English. }\end{array}$ & \\
\hline $\begin{array}{l}\text { 3. Feels comfortable entering a Somali } \\
\text { household }\end{array}$ & $\begin{array}{l}\text { 3. Feels comfortable entering a Somali } \\
\text { household. }\end{array}$ & \\
\hline 4. Cannot read or write in another language. & $\begin{array}{l}\text { 4. Cannot read or write in another } \\
\text { language. }\end{array}$ & \\
\hline 5. Hopes to become friends with student. & 5. Became friends with student. & \\
\hline $\begin{array}{l}\text { 6. Does not plain to spend more than one hour a } \\
\text { day preparing lessons. }\end{array}$ & $\begin{array}{l}\text { 6. Did not spend more that one hour it } \\
\text { day preparing lessons. }\end{array}$ & \\
\hline $\begin{array}{l}\text { 7. Does have experience training someone to fill } \\
\text { out a job application. }\end{array}$ & 7. ESL training was adequate. & \\
\hline 8. Has worked with refugees before. & $\begin{array}{l}\text { 8. Literacy teaching training from LFS } \\
\text { was adequate. }\end{array}$ & ++ \\
\hline 9. Has not been to Africa. & $\begin{array}{l}\text { 9. Cultural training at LFS was } \\
\text { adequate. }\end{array}$ & ++ \\
\hline \multirow[t]{7}{*}{$\begin{array}{l}\text { 10. Has ESL tutoring experience - "At Rose City } \\
\text { Apartments through Multnomah County Health } \\
\text { Center." }\end{array}$} & $\begin{array}{l}\text { 10. Received adequate support from } \\
\text { LFS staff. }\end{array}$ & ++ \\
\hline & $\begin{array}{l}\text { 11. Student did homework outside of } \\
\text { tutoring session. }\end{array}$ & ++ \\
\hline & 12. Student achieved her goals. & + \\
\hline & 13. Liked the program's cause. & ++ \\
\hline & 14. Did like the program's content. & ++ \\
\hline & 15. Wants to continue as a tutor. & + \\
\hline & $\begin{array}{l}\text { 16. Suggestions for other LFS programs } \\
\text { or comments: "It's social justice. My } \\
\text { student wanted more practical stuff. The } \\
\text { book they (LFS) provided was not } \\
\text { adequate. My student also took PCC } \\
\text { classes. The women need more case } \\
\text { management, medical help, and } \\
\text { connection to community. }\end{array}$ & \\
\hline
\end{tabular}


Identification Name: 130

Tutoring Hours Completed: 24 hours (34\% of 72 hours)

First Test: $\quad$ 9/19/99

Second Test: $\quad 6 / 30 / 00$

\begin{tabular}{|c|c|c|c|c|c|c|}
\hline 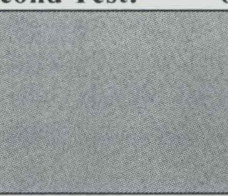 & $\begin{array}{l}\frac{\text { BEST }}{\text { Short }} \\
\frac{\text { Form }}{\text { SCORE }}\end{array}$ & $\begin{array}{l}\text { Total } \\
\text { Points } \\
\text { Possible }\end{array}$ & $\begin{array}{l}\text { BEST } \\
\text { Short } \\
\text { Form } \\
\text { Adjusted } \\
\text { SCORE }\end{array}$ & $\begin{array}{l}\text { BEST-Long } \\
\text { Form SCORE }\end{array}$ & $\begin{array}{l}\text { Total Points } \\
\text { Possible }\end{array}$ & Changes \\
\hline Total & 13 & 40 & $26 I V$ & $28 \mathrm{~V}$ & 91 & +2 \\
\hline Communication & 11 & 22 & --------- & 19 & 48 & \\
\hline Fluency & 2 & 18 & - --o---- & 5 & 24 & \\
\hline Listening & - & - -.-.-- & - -.--o-- & 4 & 11 & \\
\hline Reading/writing & - - & 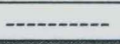 & - - - & 5 & 12 & \\
\hline Alphabet Test & 2 & 41 & --------- & 0 & 41 & Worse \\
\hline Form Test & Nothing & Perfect & --------- & $\begin{array}{l}\text { Name, month } \\
\text { and date of } \\
\text { birth, address, } \\
\text { no city, state } \\
\text { or zip, phone } \\
\text { number }\end{array}$ & Perfect & Improve \\
\hline
\end{tabular}

COMMENTS ON PARTICULAR TEST QUESTIONS

\begin{tabular}{|c|c|c|}
\hline & $\begin{array}{l}\text { Before - BEST Short } \\
\text { Form }\end{array}$ & After-BEST Long Form \\
\hline $\begin{array}{l}\text { Greetings, Personal } \\
\text { Information }\end{array}$ & 1. -5 , half correct. & 1. -8 . half. \\
\hline Describe Common Situation & 6. Home situation. & $9 .-10$ \\
\hline Time/Numbers & 7. Time. & 11. -13 . Time recognition. \\
\hline & 8. Time get up perfect. & 14. Time get up perfect. \\
\hline Directions, Clarification & 9. -16 . & 15. -22 . Cannot give directions. \\
\hline Money & 11. Recognizes money. & 23. -26 Knows money. \\
\hline Shopping, Food, Clothing & $\begin{array}{l}\text { 10., 12. Cannot ask for } \\
\text { prices. }\end{array}$ & 27. -28. Cannot ask for prices. \\
\hline Signs & & 29. -32 . Can read $1 / 2$ of all signs. \\
\hline $\begin{array}{l}\text { Emergencies, Safety Health, } \\
\text { Body Parts }\end{array}$ & 13. -15 . & 33. -41 . Answered in Somali. \\
\hline Employment, Training & 18. & 42. -45 . \\
\hline
\end{tabular}


46-49 First Name, Street Address, First Name Signature and Date without year only

\section{Alphabet \\ Before}

After

Small: abABCDEHJMNLS

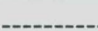

Capital:

Form

\begin{tabular}{|l|l|c|}
\hline Before & After & RESULT \\
\hline 3. No name. & 3. Name. & + \\
\hline 4. No date of birth & 4. Month and date - no year. & + \\
\hline 5. No uddress. & 5. Address - no city, no street, no zip. & + \\
\hline 6. No phone number. & 6. Phone number. & + \\
\hline 7. No household size. & 7. No houseliold size. & \\
\hline 8. No information checked off. & 8. Nothing checked off. \\
\hline $\begin{array}{l}\text { 9. No children's names, no ages, no } \\
\text { gender. }\end{array}$ & 9. No children's names, no ages, no gender. \\
\hline
\end{tabular}

\begin{tabular}{|c|c|c|}
\hline Survey One for Somali Women & Survey Two for Somali Women & Changes \\
\hline A. Print - none & A. Print - Newspaper, children's books. & + \\
\hline $\begin{array}{l}\text { B. I. Thinks leaming English will be } \\
\text { difficult. }\end{array}$ & $\begin{array}{l}\text { B. 1. Thinks learning English was } \\
\text { difficult. }\end{array}$ & \\
\hline 2. Can read and write in Somali. & 2. Camnot read and write in Somali. & - \\
\hline 3. Cannot read in English. & 3. Can read in English - intermediate level. & + \\
\hline 4. Can write the alphabet in English. & 4. Can write the alphabet in English. & \\
\hline 5. Camnot write sentences in English. & $\begin{array}{l}\text { 5. Can write sentences in English - basic } \\
\text { sentences } 3-5 \text { words. }\end{array}$ & + \\
\hline $\begin{array}{l}\text { 6. Camot speak on the phone in } \\
\text { English. }\end{array}$ & 6. Cannot speak on the phone in English. & \\
\hline $\begin{array}{l}\text { 7. Cannot fill out a job application in } \\
\text { English. }\end{array}$ & $\begin{array}{l}\text { 7. Camnot fill out a job application in } \\
\text { English. }\end{array}$ & \\
\hline $\begin{array}{l}\text { 8. Has family encouragement to learn } \\
\text { English. }\end{array}$ & $\begin{array}{l}\text { 8. Had family encouragement to learn } \\
\text { English. }\end{array}$ & ++ \\
\hline $\begin{array}{l}\text { 9. Plans to spend more than } 1 \text { hour a } \\
\text { day studying. }\end{array}$ & $\begin{array}{l}\text { 9. Did spend more than } 1 \text { hour a day } \\
\text { studying. }\end{array}$ & ++ \\
\hline 10. Looking forward to meeting tutor. & 10. Tutor became a friend. & ++ \\
\hline 11. Studied English in the US. & $\begin{array}{l}\text { 11. Tutor was a good teacher. "Now bad - } \\
\text { no teacher - no good." }\end{array}$ & ++ \\
\hline C. Goal is "to be self-sufficient." & $\begin{array}{l}\text { 12. Did not achieve goals. Suggests that } \\
\text { Lutheran Family arrange for a tutor to come } \\
\text { to her house more than two or three times a } \\
\text { week. }\end{array}$ & -- \\
\hline
\end{tabular}




\begin{tabular}{|c|c|c|}
\hline Survey One for Tutors & Survey Two for Tutors & Changes \\
\hline $\begin{array}{l}\text { 1. Thinks teaching English will } \\
\text { not be difficult. }\end{array}$ & 1. Teaching English was difficult. & - \\
\hline $\begin{array}{l}\text { 2. Feels comfortable with } \\
\text { people who do not speak } \\
\text { English. }\end{array}$ & $\begin{array}{l}\text { 2. Feels comfortable with people who do not speak } \\
\text { English. }\end{array}$ & + \\
\hline $\begin{array}{l}\text { 3. Feels comfortable entering a } \\
\text { Somali household. }\end{array}$ & 3. Feels comfortable entering a Somali household. & + \\
\hline $\begin{array}{l}\text { 4. Can read or write in another } \\
\text { language. }\end{array}$ & 4. Can read or write in another language. & \\
\hline $\begin{array}{l}\text { 5. Hopes to become friends with } \\
\text { student. }\end{array}$ & 5. Became friends with student. & + \\
\hline $\begin{array}{l}\text { 6. Does not plan to snend more } \\
\text { than one hour a day preparing } \\
\text { lessons. }\end{array}$ & $\begin{array}{l}\text { 6. Did not spend more than one hour a day } \\
\text { preparing lessons. }\end{array}$ & \\
\hline $\begin{array}{l}\text { 7. Does have experience } \\
\text { training someone to fill out a job } \\
\text { application. }\end{array}$ & 11. ESL training at LFS was not adequate: & - \\
\hline $\begin{array}{l}\text { 8. Has not worked with refugees } \\
\text { before. }\end{array}$ & 8 Literacy training at LFS was not adequate. & - \\
\hline Has not been to Africa. & 9. Cultural training at LFS was adequate. & + \\
\hline $\begin{array}{l}\text { 10. Has no ESI tutoring } \\
\text { experience. }\end{array}$ & 10. Received adequate support from LFS staff. & + \\
\hline & $\begin{array}{l}\text { 11. Student did not study outside of tutoring } \\
\text { session. "I." }\end{array}$ & - \\
\hline & 12. Student did not achleve her goals. & - \\
\hline & $\begin{array}{l}\text { 13. Liked the program's cause. "If Lutheran Family } \\
\text { Service wasn't focusing on Somali women - who's } \\
\text { going to do it?" }\end{array}$ & + \\
\hline & 14. Liked the program's content. & + \\
\hline & 15. Does not want to continue as a tutor: & - \\
\hline & 16. Suggestions for other LFS programs: none. & \\
\hline
\end{tabular}


Identification Name: 140

Tutoring Hours Completed: 16 hours (22\% of 72 hours)

First Test: $\quad 12 / 9 / 99$

Second Test: $\quad 7 / 1 / 00$

\begin{tabular}{|c|c|c|c|c|c|c|}
\hline 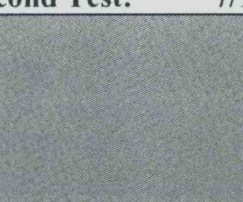 & $\begin{array}{l}\text { BEST-Short } \\
\text { Form } \\
\text { SCORE }\end{array}$ & $\begin{array}{l}\text { Total } \\
\text { Points } \\
\text { Possible }\end{array}$ & $\begin{array}{l}\text { BEST } \\
\text { Short } \\
\text { Form } \\
\text { Adjusted } \\
\text { SCORE }\end{array}$ & $\begin{array}{l}\text { BEST- } \\
\text { Long Form } \\
\text { SCORE }\end{array}$ & $\begin{array}{l}\text { Total } \\
\text { Points } \\
\text { Possible }\end{array}$ & Changes \\
\hline Total & 7 & 40 & 1511 & 21 III & 91 & +6 \\
\hline Communication & 4 & 22 & 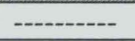 & 12 & 48 & \\
\hline Fluency & 3 & 18 & -------- & 4 & 24 & \\
\hline Listening & - & - & 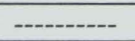 & 5 & 11 & \\
\hline Reading/writing & - - & - & -------- & 1 & 12 & \\
\hline Alphabet Test & 0 & 41 & 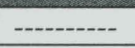 & 2 & 41 & Improve \\
\hline Form Test & Nothing & Perfect & --------- & Nothing & Perfect & $\begin{array}{l}\text { No } \\
\text { Improve } \\
\text { ment }\end{array}$ \\
\hline
\end{tabular}

COMMENTS ON PARTICULAR TEST QUESTIONS

\begin{tabular}{|c|c|c|}
\hline & Before - BEST Short Form & After-BEST Long Form \\
\hline $\begin{array}{l}\text { Greetings, Personal } \\
\text { Information }\end{array}$ & $\begin{array}{l}\text { 1. }-5 \text {. Half correct - answered } \\
\text { correctly in Somali. }\end{array}$ & 1. -8 \\
\hline $\begin{array}{l}\text { Describe Common } \\
\text { Situation }\end{array}$ & 6. Home situation, & 9. -10 . \\
\hline Time/Numbers & $\begin{array}{l}\text { 7. Time. } \\
\text { 8. Time get un nerfect }\end{array}$ & $\begin{array}{l}\text { 11. }-13 \text {. Time recognition. } \\
\text { 14. Time get un nerfect. }\end{array}$ \\
\hline Directions, Clarification & 9. - -16. Caninot. & 15.-20. Cannot. \\
\hline Money & 11. Recognizes money. & 25. -16 Knows money. \\
\hline Shopping, Food, Clothing & $\begin{array}{l}\text { 10. 12. Cannot ask for } \\
\text { prices }\end{array}$ & 27. -28. Cannol ask for prices. \\
\hline Signs & & 29. -32. Can read 1 of 4 signs. \\
\hline $\begin{array}{l}\text { Emergencies, Safety } \\
\text { Health, Body Parts }\end{array}$ & 13. -15 & 33. -41 . \\
\hline Employment, Training & 18. & 42. -45 . One correct. \\
\hline
\end{tabular}


LONG FORM

$140 \quad 2 / 3$

46-49 0/8pts. First name singed on "date"

line

Before

After

AABGC

Capital: -----

Form

\begin{tabular}{|c|c|c|}
\hline Before & After & RESULT \\
\hline 3. No name. & 3. No name & -- \\
\hline 4. No date of birth. & 4. No dare of binth. & -- \\
\hline 5. No addrest & 5. No address. & -- \\
\hline 6. No phone number. & 6. No phone number: & -- \\
\hline 7. No household size. & 7. No household size. & -- \\
\hline 8. No information cheeked- off: & 8. No informarion checked-off. & -- \\
\hline $\begin{array}{l}\text { 9. No children's names, no ages. } \\
\text { no gender. }\end{array}$ & $\begin{array}{l}\text { 9. No childrea's names, no ages, no } \\
\text { gender. }\end{array}$ & -- \\
\hline 10. No signature, no date. & 10. No signature, no date. & -- \\
\hline
\end{tabular}

\begin{tabular}{|c|c|c|}
\hline $\begin{array}{l}\text { Survey One for Somali } \\
\text { Women }\end{array}$ & Survey Two for Somali Women & Changes \\
\hline A. Print - none. & A. Print none. & \\
\hline $\begin{array}{l}\text { B. } 1 \text { Tlinks learning English } \\
\text { will be difficult. }\end{array}$ & B. 1. Thinks leaming English was difficult. & + \\
\hline $\begin{array}{l}\text { 2. Camnot read and write in } \\
\text { Sonali. }\end{array}$ & 2. Cannot read and write in Somali. & \\
\hline 3. Cannot read in Enghsh. & 3. Can read in English - beginning level. & + \\
\hline $\begin{array}{l}\text { 4. Camnot write the alphabet } \\
\text { in Enstish. }\end{array}$ & $\begin{array}{l}\text { 4. Can write the alphabet in English - "a } \\
\text { little." }\end{array}$ & + \\
\hline $\begin{array}{l}\text { 5. Cannot write sentences in } \\
\text { English. }\end{array}$ & 5. Cannot write sentences in English. & \\
\hline $\begin{array}{l}\text { 6. Cannot speak on the phone } \\
\text { in English. }\end{array}$ & 6. Can speak on the phone in English. & + \\
\hline $\begin{array}{l}\text { 7. Camnot fill out a job } \\
\text { application in English. }\end{array}$ & $\begin{array}{l}\text { 7. Camiot fill ont a job application in } \\
\text { English. }\end{array}$ & \\
\hline $\begin{array}{l}\text { 8. Has family encouragement } \\
\text { to learn English. }\end{array}$ & $\begin{array}{l}\text { 8. Had family encouragement to learn } \\
\text { English. }\end{array}$ & ++ \\
\hline $\begin{array}{l}\text { 9. Plans to spend more than } 1 \\
\text { hour a day studying. }\end{array}$ & $\begin{array}{l}\text { 9. Did not spend more and } 1 \text { hour a day } \\
\text { studying - also with TV. }\end{array}$ & - \\
\hline $\begin{array}{l}\text { 10. Looking forward to } \\
\text { meeting tutor. }\end{array}$ & 10. Tutor became a friend. & ++ \\
\hline $\begin{array}{l}\text { 11. Studied English in the US } \\
\text { at IRCO and Steps for } \\
\text { Success for } 3 \text { months. }\end{array}$ & 11. Tutor was a good teacher. & ++ \\
\hline $\begin{array}{l}\text { C. Goals are "to be able to } \\
\text { communicate fluently." }\end{array}$ & $\begin{array}{l}\text { 12. Did not aclueve goals. "I want to learn } \\
\text { English at PCC. When my daughters are } \\
\text { not here, I can't even answer the phone." } \\
\text { When my illness got worse, I only leamed a } \\
\text { little bit." "When they killed him. I fell } \\
\text { down. "I want to have a tutor - to leam it" } \\
\text { personal." }\end{array}$ & - \\
\hline
\end{tabular}




\begin{tabular}{|c|c|c|}
\hline Survey One for Tutors & Survey Two for Tutors & Changes \\
\hline $\begin{array}{l}\text { 1. Thinks teaching English will } \\
\text { not be difficult. }\end{array}$ & 1. Teaching Euglish was difficult & - \\
\hline $\begin{array}{l}\text { 2. Feels comfortable with people } \\
\text { who do not speak English. }\end{array}$ & $\begin{array}{l}\text { 2. Feels comfortable with people who do not speak } \\
\text { English. }\end{array}$ & \\
\hline $\begin{array}{l}\text { 3. Feels comfortable entering a } \\
\text { Somali household }\end{array}$ & 3. Feels comfortable entering a Somali household. & \\
\hline $\begin{array}{l}\text { 4. Can read or write in another } \\
\text { language. }\end{array}$ & 4. Can read or write in another language. & \\
\hline $\begin{array}{l}\text { 5. Hopes to become friends with } \\
\text { student. }\end{array}$ & 5. Became friends with student. & + \\
\hline $\begin{array}{l}\text { 6. Does not plan to spend more } \\
\text { than one hour a day preparing } \\
\text { lessons. }\end{array}$ & $\begin{array}{l}\text { 6. Did spend more than one hour a day preparing } \\
\text { lessons "I spent a huge amount of time up front. We } \\
\text { were never able to get through the material. }\end{array}$ & + \\
\hline $\begin{array}{l}\text { 7. Does have experience training } \\
\text { someone to fill out a job } \\
\text { application. }\end{array}$ & $\begin{array}{l}\text { 12. N/A - Did not attend (ESL training was } \\
\text { adequate.) }\end{array}$ & \\
\hline $\begin{array}{l}8 . \text { Has worked with refugees } \\
\text { before. }\end{array}$ & $\begin{array}{l}\text { 8. N/A - Did not attend (Literacy teaching training } \\
\text { from LFS was adequate.) }\end{array}$ & ++ \\
\hline 9. 1 las not been to Africa.- & 9. Cultural training at LFS was adequate. & ++ \\
\hline \multirow{7}{*}{$\begin{array}{l}\text { 10. Has ESL tutoring experience - } \\
\text { Mexican children. }\end{array}$} & 10. Received adequate support from LFS staff. & ++ \\
\hline & $\begin{array}{l}\text { 11. Student did homework outside of tutoring } \\
\text { session. }\end{array}$ & ++ \\
\hline & 12. Student did not achieve her goals: & \\
\hline & $\begin{array}{l}\text { 13. Liked the program's cause. "It's worthwhile to } \\
\text { help anybody to function. It is beneficial." }\end{array}$ & ++ \\
\hline & $\begin{array}{l}\text { 14. Did not like the program's content. "I think my } \\
\text { student had more deficiencies than others in the } \\
\text { groun. }\end{array}$ & ++ \\
\hline & 15. Wants to continue as a tutor. & + \\
\hline & $\begin{array}{l}\text { 16. Suggestions for other LFS programs: "They } \\
\text { should provide more cultural training for the } \\
\text { Somalis. They gave us a good background on the } \\
\text { Somalis and the Somalis should receive it also." }\end{array}$ & \\
\hline
\end{tabular}


Identification Name: 150

Tutoring Hours Completed: 0 hours

First Test: $\quad 9 / 19 / 99$

Second Test: $\quad 6 / 30 / 00$

\begin{tabular}{|c|c|c|c|c|c|c|}
\hline & $\begin{array}{l}\text { BEST - } \\
\text { Short } \\
\text { Form } \\
\text { SCORE }\end{array}$ & $\begin{array}{l}\text { Total } \\
\text { Points } \\
\text { Possible }\end{array}$ & $\begin{array}{l}\text { BEST } \\
\text { Short } \\
\text { Form } \\
\text { Adjusted } \\
\text { SCORE }\end{array}$ & $\frac{\text { BEST-Long }}{\text { Form SCORE }}$ & $\begin{array}{l}\text { Total } \\
\text { Points } \\
\text { Possible }\end{array}$ & Changes \\
\hline Total & 2 & 40 & 50 & 111 & 91 & +6 \\
\hline Communication & 2 & 22 & -...-- & 8 & 48 & \\
\hline Fluency & 0 & 18 & -.--- & 2 & 24 & \\
\hline Listening & -..-- & --o-- & ----- & 1 & 11 & \\
\hline Reading/writing & - --.---- & --------- & --------- & 0 & 12 & \\
\hline Alnhabet Test & 0 & 41 & & 0 & 41 & \\
\hline Form Test & Nothing & Perfect & - & Nothing & Perfect & \\
\hline
\end{tabular}

\section{COMMENTS ON PARTICULAR TEST QUESTIONS}

46-49 First Name and Date without year only

Alphabet

\section{Before}

Small:

Capital:

\section{After}

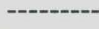

\section{Form}

\begin{tabular}{|c|c|c|}
\hline Before & After & RESULT \\
\hline 3. No name. & 3. No name. & \\
\hline 4. No date of hirth. & 4. No date or birth & \\
\hline 5. No adidress. & 5. No address: & \\
\hline 6. No plione number: & 6. No plione number: & \\
\hline 7. No household size. & 7. No houschold size. & \\
\hline 8. No information checked-off. & 8. Nothing checked-off: & \\
\hline $\begin{array}{l}\text { 9. No children's names, no ages, no } \\
\text { gender. }\end{array}$ & $\begin{array}{l}\text { 9. No clildren's names, no } \\
\text { ages, no gender. }\end{array}$ & \\
\hline 10. No signatire, no date. & 10. No signature, no date. & \\
\hline
\end{tabular}


$150 \quad 2 / 2$

\begin{tabular}{|c|c|c|}
\hline Survey One for Somali Women & Survey Two for Somali Women & Changes \\
\hline A. No print. & A. No print. & \\
\hline $\begin{array}{l}\text { B. 1. Thinks leaming English will not } \\
\text { be difficult. }\end{array}$ & $\begin{array}{l}\text { B. Thinks learning English was } \\
\text { difficult. }\end{array}$ & \\
\hline 2. Cannot read and write in Somali. & 2. Cannot read and white in Somall. & \\
\hline 3. Cannot read in English. & 3. Camot read in English. & \\
\hline 4. Cannot write the alphabet in English. & 4. Cammot write the alphabet in English & \\
\hline 5. Cannot write sentences in English. & 5. Cannot write sentences in English. & \\
\hline $\begin{array}{l}\text { 6. Camnot speak on the phone in } \\
\text { kinglish. }\end{array}$ & $\begin{array}{l}\text { 6. Camnot speak on the phone in } \\
\text { English. }\end{array}$ & \\
\hline $\begin{array}{l}\text { 7. Cannot fill out a job application in } \\
\text { English. }\end{array}$ & $\begin{array}{l}\text { 7. Cannot fill out a job application in } \\
\text { English. }\end{array}$ & \\
\hline $\begin{array}{l}\text { 8. Has family encouragement to learn } \\
\text { English. }\end{array}$ & $\begin{array}{l}\text { 8. Had family encouragement to learn } \\
\text { English. }\end{array}$ & \\
\hline $\begin{array}{l}\text { 9. Does not plan to spend more than } 1 \\
\text { hour a day studying. }\end{array}$ & $\begin{array}{l}\text { 9. Did not spend more than I hour a } \\
\text { day studying. }\end{array}$ & \\
\hline 10. Looking forward to meeting tutor. & $\begin{array}{l}\text { 10. N/A - Become friends with tutor -- } \\
\text { No tutor. }\end{array}$ & \\
\hline $\begin{array}{l}\text { 11. Studied English for } 6 \text { months in } \\
\text { Maryland. }\end{array}$ & $\begin{array}{l}\text { 11. N/A - Tutor was a good teacher -- } \\
\text { No tutor. }\end{array}$ & \\
\hline $\begin{array}{l}\text { C. Goals are "to be able to talk with } \\
\text { doctors, go shopping and be able to ask } \\
\text { for the things I need." }\end{array}$ & C. Did not achieve goals. & - \\
\hline
\end{tabular}

* Had no tutor 
Identification Name: 160

$1601 / 3$

Tutoring Hours Completed: 64 hours (89\% of 72 hours)

First Test: $\quad \quad 9 / 20 / 99$

Second Test: $\quad 4 / 26 / 00$

\begin{tabular}{|c|c|c|c|c|c|c|}
\hline & $\begin{array}{l}\text { BEST -Short } \\
\text { Form } \\
\text { SCORE }\end{array}$ & $\begin{array}{l}\text { Total Points } \\
\text { Possible }\end{array}$ & $\begin{array}{l}\text { BEST } \\
\text { Short } \\
\text { Form } \\
\text { Adjusted } \\
\text { SCORE }\end{array}$ & $\begin{array}{l}\frac{\text { BEST- }}{\text { Long }} \\
\text { Form } \\
\text { SCORE }\end{array}$ & $\begin{array}{l}\text { Total } \\
\text { Points } \\
\text { Possible }\end{array}$ & Changes \\
\hline Total & 7 & 40 & $15 \mathrm{II}$ & 22 III & 91 & +8 \\
\hline Communication & 6 & 22 & --------- & 16 & 48 & \\
\hline Fluency & 1 & 18 & -------- & 0 & 24 & \\
\hline Listening & --.-- & --------- & --------- & 6 & 11 & \\
\hline Reading/writing & - ------- & --------- & --------- & 3 & 12 & \\
\hline Alphabet Test & 1 & 41 & --------- & 1 & 41 & Improve, \\
\hline Form Test & $\begin{array}{l}\text { First Name } \\
\text { only - in the } \\
\text { phone } \\
\text { number } \\
\text { place }\end{array}$ & Perfect & --------- & $\begin{array}{l}\text { Random } \\
\text { numbers } \\
\text { only on } \\
\text { address } \\
\text { and phone } \\
\text { places }\end{array}$ & Perfect & Worse \\
\hline
\end{tabular}

COMMENTS ON PARTICULAR TEST QUESTIONS

\begin{tabular}{|c|c|c|}
\hline & $\begin{array}{l}\text { Before - BEST Short } \\
\text { Form }\end{array}$ & After-BEST Long Form \\
\hline $\begin{array}{l}\text { Greetings, Personal } \\
\text { Information }\end{array}$ & $\begin{array}{l}\text { 1. }-5 . \text { Half correct - } \\
\text { answered correctly in } \\
\text { Somali. }\end{array}$ & 1. -8 \\
\hline $\begin{array}{l}\text { Describe Common } \\
\text { Situation }\end{array}$ & 6. Home siluation. & 9. -10 \\
\hline Time/Numbers & 4. Time: & 11. -13. Time recognition. \\
\hline & 8. Time get up perfeet. & 14 Time get up. \\
\hline Directions, Clarification & 9.-16.Cannot. & 15. -20. Cannot. \\
\hline Money & $\begin{array}{l}\text { 11. Does not recoginize } \\
\text { money. }\end{array}$ & 25. - 16 Does nol know money. \\
\hline Shopping, Food, Clothing & $\begin{array}{l}\text { 10. 12. Cannol ask for } \\
\text { prices. }\end{array}$ & 27. -28. Camnot ask for prices. \\
\hline Signs & & 29. -32. Can read 3 of 4 signs. \\
\hline $\begin{array}{l}\text { Emergencies, Safety } \\
\text { Health, Body Parts }\end{array}$ & $13 \cdot-15$ & $\begin{array}{l}\text { 33. }-41 \text {. "How do you think he } \\
\text { feels?" "Dead." }\end{array}$ \\
\hline Employment, Training & 18. & 42. $-45,2$ correct. \\
\hline
\end{tabular}




\section{LONG FORM}

$1602 / 3$

46-49 Form - 0 of 8pts. Wrote first name

Alphabet

Before

Small:

on the address line

Capital: ABGCMPFHGYS

After

abABDCEHTmpty

Form

\begin{tabular}{|c|c|c|}
\hline Before & After & RESULT \\
\hline 3. No name. & 3. No name. & \\
\hline 4. No date of birth. & 4. No date of bintli. & \\
\hline 5. No address: & 5. No address "12345"6 $78910^{\prime \prime}$ & \\
\hline 6. No phone number - "HAISA-CKM." & $\begin{array}{l}\text { 6. No phone number } \\
\text { "1 } 115131415121711912 .\end{array}$ & \\
\hline 7. No household size. & 7. No houschold size. & \\
\hline 8. No information checked-off. & 8. No Information checked-off: & \\
\hline $\begin{array}{l}\text { 9. No Children's names only, no ages, no } \\
\text { gender. }\end{array}$ & $\begin{array}{l}\text { 9. No children's mames, no ages, } \\
\text { no sex }\end{array}$ & \\
\hline 10. No signature, no date. & 10. No signature, no date. & \\
\hline
\end{tabular}

\begin{tabular}{|c|c|c|}
\hline Survey One for Somali Women & Survey Two for Somali Women & Changes \\
\hline A. Print-wone. & $\begin{array}{l}\text { A. Print - Koran prayers, First } \\
\text { grader's homework. }\end{array}$ & + \\
\hline $\begin{array}{l}\text { B. 1. Thinks learning English will be } \\
\text { difficult }\end{array}$ & $\begin{array}{l}\text { B. 1. Thinks learning English } \\
\text { was difficult. }\end{array}$ & \\
\hline 2. Cannot read and write in Somali. & $\begin{array}{l}\text { 2. Cannot read and write in } \\
\text { Somali. }\end{array}$ & \\
\hline 3. Camnot read in English. & $\begin{array}{l}\text { 3. Can read in English - } \\
\text { beginning level. }\end{array}$ & + \\
\hline 4. Cannot write the alphabet in English. & $\begin{array}{l}\text { 4. Can write the alphabet in } \\
\text { English "When I see it." }\end{array}$ & \\
\hline 5. Cannot write sentences in English. & $\begin{array}{l}\text { 5. Can write sentences in English } \\
\text { - basic sentences } 3-5 \text { words } \\
\text { "When I copy them." }\end{array}$ & + \\
\hline 6. Camnot speak on the phione in English. & $\begin{array}{l}\text { 6. Camnot speak on the plione in } \\
\text { English. }\end{array}$ & \\
\hline $\begin{array}{l}\text { 7. Camot fill out a job application in } \\
\text { English }\end{array}$ & $\begin{array}{l}\text { 7. Camnot fill out a job } \\
\text { application in English. }\end{array}$ & \\
\hline $\begin{array}{l}\text { 8. Has family encouragement to learn } \\
\text { English. }\end{array}$ & $\begin{array}{l}\text { 8. Had family encouragement to } \\
\text { learn English. }\end{array}$ & \\
\hline $\begin{array}{l}\text { 9. Plans to spend more than } 1 \text { hour a day } \\
\text { studying. }\end{array}$ & $\begin{array}{l}\text { 9. Did not spend more thain } 1 \text { hour } \\
\text { a day studying. II did not go to } \\
\text { sehool in Somalia so I am not } \\
\text { used to stirlying. }\end{array}$ & - \\
\hline 10. Looking forward to meeting tutor. & 10. Tutor became a friend. & ++ \\
\hline 11. Studied English at Steps for Success. & 11. Tutor was a good teacher. & ++ \\
\hline $\begin{array}{l}\text { C. Goals are "to be able to read, to help } \\
\text { my children, to talk to a doctor and to } \\
\text { talk to a dentist." }\end{array}$ & $\begin{array}{l}\text { 12. Did not achieve goals. "I } \\
\text { wanted to but I can't. When the } \\
\text { teacher is here I kind of know it } \\
\text { but when she is gone, } 1 \text { can't hold } \\
\text { on to it." }\end{array}$ & - \\
\hline
\end{tabular}




\begin{tabular}{|c|c|c|}
\hline Survey One for Tutors & Survey Two for Tutors & Changes \\
\hline $\begin{array}{l}\text { 1. Thinks teaching English will be } \\
\text { difficult. }\end{array}$ & $\begin{array}{l}\text { 1. Teaching English was } \\
\text { difficult. }\end{array}$ & \\
\hline $\begin{array}{l}\text { 2. Feels comfortable with people who do } \\
\text { not speak English. }\end{array}$ & $\begin{array}{l}\text { 2. Does not feel comfortable } \\
\text { With people who do not speak } \\
\text { English. }\end{array}$ & - \\
\hline $\begin{array}{l}\text { 3. Feels comfortable entering a Somali } \\
\text { household. }\end{array}$ & $\begin{array}{l}\text { 3. Feels comfortable entering a } \\
\text { Somali household. }\end{array}$ & \\
\hline 4. Can read or write in another language. & $\begin{array}{l}\text { 4. Can read or write in another } \\
\text { language. }\end{array}$ & \\
\hline 5. Hopes to become friends with student. & $\begin{array}{l}\text { 5. Did not become firends with } \\
\text { student. "I liked her but it didn't } \\
\text { last. It was my fault." }\end{array}$ & - \\
\hline $\begin{array}{l}\text { 6. Does not plan to spend more than one } \\
\text { hour a day preparing lessons. "Four } \\
\text { hours" (one per hour of lessons.) }\end{array}$ & $\begin{array}{l}\text { 6. Spent more than one hour a } \\
\text { day preparing lessons. }\end{array}$ & - \\
\hline $\begin{array}{l}\text { 7. Does not have experience training } \\
\text { someone to fill out a job application. }\end{array}$ & 13. ESL training was adequate. & ++ \\
\hline 8. Has not worked with refigees before. & $\begin{array}{l}\text { 8. Literacy teaching training } \\
\text { from LFS was adequate. }\end{array}$ & ++ \\
\hline 13. Has not been to Africa & $\begin{array}{l}\text { 9. Cultural training at LFS was } \\
\text { adequate. }\end{array}$ & ++ \\
\hline \multirow[t]{7}{*}{ 10. Has no ESL tutoring experience: } & $\begin{array}{l}\text { 10. Received adequate support } \\
\text { from LFS staff. }\end{array}$ & ++ \\
\hline & $\begin{array}{l}\text { 11. Student did not do } \\
\text { homework outside of tutoring } \\
\text { session. "Rarely " }\end{array}$ & - \\
\hline & $\begin{array}{l}\text { 12. Student did not achieve her } \\
\text { goals. }\end{array}$ & - \\
\hline & 13. Liked the program's cause. & ++ \\
\hline & 14. Liked the program's content. & ++ \\
\hline & $\begin{array}{l}\text { 15. Does not want to continue } \\
\text { as a tutor. "I am gum shy. My } \\
\text { problems are so individual." }\end{array}$ & \\
\hline & $\begin{array}{l}\text { 16. Suggestions for other LFS } \\
\text { programs: "Family planning, } \\
\text { birth control is really, really } \\
\text { important." }\end{array}$ & \\
\hline
\end{tabular}


Identification Name: 170

Tutoring Hours Completed: 56 hours $(78 \%$ of 72 hours)

First Test: $\quad$ 9/19/99

Second Test: $\quad 7 / 29 / 00$

\begin{tabular}{|c|c|c|c|c|c|c|}
\hline & $\begin{array}{l}\text { BEST - Short } \\
\text { Form SCORE }\end{array}$ & $\begin{array}{l}\text { Total } \\
\text { Points } \\
\text { Possible }\end{array}$ & $\begin{array}{l}\text { BEST } \\
\text { Short } \\
\text { Form } \\
\text { Adjusted } \\
\text { SCORE }\end{array}$ & $\begin{array}{l}\text { BEST-Long } \\
\text { Form } \\
\text { SCORE }\end{array}$ & $\begin{array}{l}\text { Total } \\
\text { Points } \\
\text { Possible }\end{array}$ & Changes \\
\hline Total & 29 & 40 & $57 \mathrm{VII}$ & 68 VII & 91 & +11 \\
\hline Communication & 18 & 22 & --------- & 46 & 48 & \\
\hline Fluency & 11 & 18 & --------- & 17 & 24 & \\
\hline Listening & - - & - - & - - - & 5 & 11 & \\
\hline Reading/writing & - & --------- & -------- & 7 & 12 & \\
\hline Alphabet Test & 32 & 41 & ------- & 34 & 41 & Improve \\
\hline Form Test & $\begin{array}{l}\text { Partial, Full } \\
\text { Name, year of } \\
\text { Date of Birth } \\
\text { only, no street } \\
\text { on address, } \\
\text { listed only one } \\
\text { child, signed } \\
\text { name with } \\
\text { date }\end{array}$ & Perfect & --------- & $\begin{array}{l}\text { Partial, year } \\
\text { of birth, } \\
\text { street } \\
\text { number only, } \\
3 \text { children's } \\
\text { names and } \\
\text { ages }\end{array}$ & Perfect & Worse \\
\hline
\end{tabular}

COMMENTS ON PARTICULAR TEST QUESTIONS

\begin{tabular}{|c|c|c|}
\hline & Before - BEST Short Form & $\begin{array}{l}\text { After-BEST Long } \\
\text { Form }\end{array}$ \\
\hline Greetings, Personal Information & 1. -5 . Missed one. & 1. -8. \\
\hline Describe Common Situation & 6. Home situation. & 9. -10 . \\
\hline Time/Numbers & 7. Time & $\begin{array}{l}\text { 11. }-13 \text {. Time } \\
\text { recognition. }\end{array}$ \\
\hline & 8. Time get up perfect. & 14. Time get up. \\
\hline Directions, Clarification & 9. -16 & $\begin{array}{l}\text { 15. }-20 \text {. Cannot give } \\
\text { all directions. }\end{array}$ \\
\hline Money & 11. Does recognize money. & $\begin{array}{l}\text { 25. }-16 \text { Does know } \\
\text { money. }\end{array}$ \\
\hline Shopping, Food, Clothing & 10., 12. Cannot ask for prices. & $\begin{array}{l}\text { 27. }-28 \text {. Can ask for } \\
\text { prices. }\end{array}$ \\
\hline Signs & & $\begin{array}{l}\text { 29. }-32 . \text { Can read } 3 \\
\text { of } 4 \text { signs. }\end{array}$ \\
\hline $\begin{array}{l}\text { Emergencies, Safety Health, Body } \\
\text { Parts }\end{array}$ & 13. -15 . Missed one. & 33. -41 \\
\hline Employment, Training & 18. & 42. -45 . All correct. \\
\hline
\end{tabular}


LONG FORM

46-49 Form -7 of 8pts. Address is missing the city, state and zip

Before

Small: abcDEFGHmpeTtERyhly

\section{Alphabet}

\section{After}

abcdefGHiJKLmnopqRStuvwxyz

Capital: ABCDEFGHiJKPlmnoPqRSTuvwxyz ABCDEFGHIjKLMNOPqRSTuvwxYZ

\section{Form}

\begin{tabular}{|l|l|l|}
\hline Before & After & RESULT \\
\hline 3. Full name. & $\begin{array}{l}\text { 3. Name - no middle name } \\
\text { 4. Only year on Date of Birth. }\end{array}$ & - Only year on Date of Birth. \\
\hline $\begin{array}{l}\text { 5. House number, city, state and zip - no } \\
\text { street on the address. }\end{array}$ & \begin{tabular}{l} 
5. House number only for address \\
\hline 6. Phone number.
\end{tabular} & \\
\hline $\begin{array}{l}\text { 7. No household size. } \\
\text { 8. No information checked-off: }\end{array}$ & $\begin{array}{l}\text { 7. Household size } \\
\text { 9. One child's name, no ages, no } \\
\text { gender. }\end{array}$ & $\begin{array}{l}\text { 9. Three children's names, ages, } \\
\text { no gender. }\end{array}$ \\
\hline 10. Signature (first name only), date. & 10. No signature, no date. & - \\
\hline
\end{tabular}

\begin{tabular}{|c|c|c|}
\hline Survey One for Somali Women & Survey Two for Somali Women & Changes \\
\hline A. Print - Newspaper. & $\begin{array}{l}\text { A. Print - Magazines, newspapers, } \\
\text { children's books. }\end{array}$ & + \\
\hline $\begin{array}{l}\text { B. 1. Thinks learning English will be } \\
\text { difficult. }\end{array}$ & $\begin{array}{l}\text { B. 1. Thinks learning English was } \\
\text { difficult. }\end{array}$ & \\
\hline 2. Can read and write in Somali. & 2. Can read and write in Somali. & \\
\hline $\begin{array}{l}\text { 3. Can read in English - intermediate } \\
\text { level. }\end{array}$ & 3. Can read in English. & \\
\hline 4. Can write the alphabet in English. & 4. Can write the alphabet in English. & \\
\hline $\begin{array}{l}\text { 5. Can write sentences in English - } \\
\text { long sentences - more than } 5 \text { words. }\end{array}$ & $\begin{array}{l}\text { 5. Can write sentences in English - } \\
\text { long sentences - more than } 5 \text { words. }\end{array}$ & \\
\hline 6. Can speak on the phone in English. & $\begin{array}{l}\text { 6. Can speak on the phone in } \\
\text { English. }\end{array}$ & \\
\hline $\begin{array}{l}\text { 7. Can fill out a job application in } \\
\text { English. }\end{array}$ & $\begin{array}{l}\text { 7. Can fill out a job application in } \\
\text { English. }\end{array}$ & \\
\hline $\begin{array}{l}\text { 8. Has family encouragement to learn } \\
\text { English. }\end{array}$ & $\begin{array}{l}\text { 8. Had family encouragement to } \\
\text { learn English. }\end{array}$ & \\
\hline $\begin{array}{l}\text { 9. Plans to spend more than } 1 \text { hour a } \\
\text { day studying. }\end{array}$ & $\begin{array}{l}\text { 9. Spent more and } 1 \text { hour a day } \\
\text { studying - also with TV. }\end{array}$ & + \\
\hline 10. Looking forward to meeting tutor. & 10. Tutor became a friend. & ++ \\
\hline $\begin{array}{l}\text { 11. Studied English in the US at Steps } \\
\text { for Success. }\end{array}$ & 11. Tutor was a good teacher. & ++ \\
\hline $\begin{array}{l}\text { C. Goals are "to be able to talk with a } \\
\text { doctor, on a job, at school and } \\
\text { everyday use." }\end{array}$ & $\begin{array}{l}\text { 12. Did not achieve goals. } \\
\text { "Sometimes she explanis I don't } \\
\text { know new vocabulary - new words. } \\
\text { "English program with one teacher } \\
\text { is better because I stay in my home } \\
\text { is problems for niy children's } \\
\text { problems. Every time I go to class, } \\
\text { the place, the distance is far from } \\
\text { my children. My teacher comes on } \\
\text { trime. I want to solve - on time is } \\
\text { difficult for me - iny children's } \\
\text { problems." }\end{array}$ & - \\
\hline
\end{tabular}




\begin{tabular}{|c|c|c|}
\hline Survey One for Tutors & Survey Two for Tutors & Changes \\
\hline $\begin{array}{l}\text { 1. Thinks teaching English will be } \\
\text { difficult. }\end{array}$ & 1. Teaching English was not difficult. & + \\
\hline $\begin{array}{l}\text { 2. Feels comfortable with people } \\
\text { who do not speak English. }\end{array}$ & $\begin{array}{l}\text { 2. Feels comfortable with people who } \\
\text { do not speak English. }\end{array}$ & \\
\hline $\begin{array}{l}\text { 3. Feels comfortable entering a } \\
\text { Somali household. }\end{array}$ & $\begin{array}{l}\text { 3. Feels comfortable entering a } \\
\text { Somali household. }\end{array}$ & \\
\hline $\begin{array}{l}\text { 4. Cannot read or write in another } \\
\text { language. }\end{array}$ & $\begin{array}{l}\text { 4. Cannot read or write in another } \\
\text { language. }\end{array}$ & \\
\hline $\begin{array}{l}\text { 5. Hopes to become friends with } \\
\text { student. }\end{array}$ & 5. Became friends with student. & \\
\hline $\begin{array}{l}\text { 6. Does not plan to spend more than } \\
\text { one hour a day preparing lessous. }\end{array}$ & $\begin{array}{l}\text { 6. Did not spend more than one holut } \\
\text { a day preparing lessons. }\end{array}$ & \\
\hline $\begin{array}{l}\text { 7. Does not have experience training } \\
\text { someone to fill out a job application }\end{array}$ & 7. ESL training was adequate. & \\
\hline $\begin{array}{l}\text { 8. Has not worked with refugees } \\
\text { before. }\end{array}$ & $\begin{array}{l}\text { 8. Literacy teaching training from } \\
\text { LFS was adequate. }\end{array}$ & ++ \\
\hline 9. Has not been to Africa. & $\begin{array}{l}\text { 9. Cultural training at LFS was } \\
\text { adequate. }\end{array}$ & ++ \\
\hline \multirow[t]{7}{*}{ 10. Has no EST, futoring experience. } & $\begin{array}{l}\text { 10. Received adequate support from } \\
\text { LFS staff. }\end{array}$ & ++ \\
\hline & $\begin{array}{l}\text { 11. Student did homework outside of } \\
\text { tutoring session. }\end{array}$ & ++ \\
\hline & 12. Student achieved her goals. & \\
\hline & 13. Liked the program's cause. & ++ \\
\hline & $\begin{array}{l}\text { 14. Liked the program's content. "I } \\
\text { like it. This program is good. It's fun. } \\
\text { When she goes to the street, she can't } \\
\text { ask questions by herself. I made } \\
\text { vocabulary practice sheets." }\end{array}$ & ++ \\
\hline & $\begin{array}{l}\text { 15. Wants to continue as a tutor. } \\
\text { "How can I not continue? She wants } \\
\text { to learn." }\end{array}$ & + \\
\hline & $\begin{array}{l}\text { 16. Suggestions for other LFS } \\
\text { programs: none. }\end{array}$ & \\
\hline
\end{tabular}


Identification Name: 180

Tutoring Hours Completed: 64 hours (89\% of 72 hours)

First Test: 9/19/99

Second Test: $6 / 30 / 00$

\begin{tabular}{|c|c|c|c|c|c|c|}
\hline & $\begin{array}{l}\text { BEST - Short } \\
\text { Form SCORE }\end{array}$ & $\begin{array}{l}\text { Total } \\
\text { Points } \\
\text { Possible }\end{array}$ & $\begin{array}{l}\text { BEST } \\
\text { Short } \\
\text { Form } \\
\text { Adjusted } \\
\text { SCORE }\end{array}$ & $\begin{array}{l}\text { BEST- } \\
\text { Long } \\
\text { Form } \\
\text { SCORE }\end{array}$ & $\begin{array}{l}\text { Total } \\
\text { Points } \\
\text { Possible }\end{array}$ & Changes \\
\hline Total & 30 & 40 & 41 VII & $64 \mathrm{VII}$ & 94 & +23 \\
\hline Communication & 20 & 22 & 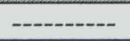 & 40 & 48 & \\
\hline Fluency & 10 & 18 & --------- & 19 & 24 & \\
\hline Listening & ----- & - -.--o-.. & 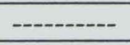 & 5 & 11 & \\
\hline Reading/writing & -------- & --------- & ---------- & 12 & 12 & \\
\hline Alphabet Test & 7 & 41 & --------- & 8 & 41 & $\begin{array}{l}\text { No real } \\
\text { improve- } \\
\text { ment }\end{array}$ \\
\hline Form Test & $\begin{array}{l}\text { Perfect except } \\
\text { no household } \\
\text { size }\end{array}$ & Perfect & --------- & $\begin{array}{l}\text { Perfect } \\
\text { except no } \\
\text { household } \\
\text { size }\end{array}$ & Perfect & $\begin{array}{l}\text { Two less } \\
\text { children } \\
\text { listed- } \\
\text { no other } \\
\text { change }\end{array}$ \\
\hline
\end{tabular}

COMMENTS ON PARTICULAR TEST QUESTIONS

\begin{tabular}{|c|c|c|}
\hline & Before - BEST Short Form & After-BEST Long Form \\
\hline $\begin{array}{l}\text { Greetings, Personal } \\
\text { Information }\end{array}$ & 1. -5 . All correct. & 1. -8 . All correct. \\
\hline Describe Common Situation & 6. Home situation. & 9. -10 \\
\hline Time/Numbers & 7. Time. & 11. -13. Time recognition. \\
\hline & 8. Time get up perfect. & 14. Time get up perfect. \\
\hline Directions, Clarification & 9. -16.Can make questions. & 15. -20 . One point missing. \\
\hline Money & 11. Recognizes money. & 25. -16 Knows money. \\
\hline Shopping, Food, Clothing & 10., 12. Can ask for prices. & 27. -28.Can ask for prices. \\
\hline Signs & & 29. -32 . Can read $1 / 2$ of all signs. \\
\hline $\begin{array}{l}\text { Emergencies, Safety Health, } \\
\text { Body Parts }\end{array}$ & $13,-15$ & 33. -41 . \\
\hline Employment, Training & 18. & 42. -45 . \\
\hline
\end{tabular}

LONG FORM

46, 48, 49 Form - 6/8pts. 
Alphabet

Before

Small: abcdlmwptey

Capital: ABDGGMPQY

Form

\begin{tabular}{|l|l|l|}
\hline Before & After & RESULT \\
\hline 3. Full name. & 3. Full name. & \\
\hline 4. Date of birth. & 4. Date of birth. & \\
\hline 5. Full address. & 5. Full address. & \\
\hline 6. Full phone number. & 6. Full phone number. & - \\
\hline 7. No household size. & 7. No hotisehold size. & \\
\hline 8. Services checked. & 8. Services checked. & - \\
\hline 9. Six children's names and full info. & $\begin{array}{l}\text { 9. Four children's names and } \\
\text { full info. }\end{array}$ & - \\
\hline 10. Signature and date. & 10. Signature and date. & \\
\hline
\end{tabular}

\begin{tabular}{|c|c|c|}
\hline Survey One for Somali Women & Survey Two for Somali Women & Changes \\
\hline A. Print-none: & A. Print none. & \\
\hline $\begin{array}{l}\text { B. 1. Thinks learning English will be } \\
\text { difficult. }\end{array}$ & $\begin{array}{l}\text { B. 1. Thinks learning English was } \\
\text { difficult. }\end{array}$ & \\
\hline 2. Can read and write in Somali & 2. Can read and write in Somali. & \\
\hline $\begin{array}{l}\text { 3. Can read in English - intermediate } \\
\text { level. }\end{array}$ & $\begin{array}{l}\text { 3. Can read in English - advanced } \\
\text { level. }\end{array}$ & + \\
\hline 4. Can write the alphabet in English. & $\begin{array}{l}\text { 4. Can write the alphabet in } \\
\text { English. }\end{array}$ & \\
\hline 5. Can't write sentences in English. & $\begin{array}{l}\text { 5. Can write sentences in English - } \\
\text { long - more than } 5 \text { words. }\end{array}$ & \\
\hline 6. Can speak on the phone in English. & $\begin{array}{l}\text { 6. Can speak on the phone in } \\
\text { English. }\end{array}$ & \\
\hline $\begin{array}{l}\text { 7. Camnot fill out a job application in } \\
\text { English " "half:" }\end{array}$ & $\begin{array}{l}\text { 7. Can fill out a job application in } \\
\text { English. }\end{array}$ & + \\
\hline $\begin{array}{l}\text { 8. Has family encouragement to learn } \\
\text { English. }\end{array}$ & $\begin{array}{l}\text { 8. Had family encouragement to } \\
\text { learn English. }\end{array}$ & \\
\hline $\begin{array}{l}\text { 9. Plans to spend more and } 1 \text { hour a } \\
\text { day studying. }\end{array}$ & $\begin{array}{l}\text { 9. Did spend more than } 1 \text { hour a } \\
\text { day studying. }\end{array}$ & \\
\hline 10. Looking forward to meeting tutor. & 10. Tutor became a friend. & \\
\hline $\begin{array}{l}\text { 11. Studied English for 1year at } \\
\text { P.C.C. }\end{array}$ & 11. Tutor was a good teacher. & \\
\hline $\begin{array}{l}\text { C. Goals are "To advanced my } \\
\text { English." }\end{array}$ & $\begin{array}{l}\text { 12. Achieved goals. "More than I } \\
\text { wanted to learn. America - my } \\
\text { country - past, present sentence, } \\
\text { writing. My daughter help me all } \\
\text { the time. She's a good teacher. She } \\
\text { helps me with my disabled } \\
\text { daughter and makes doctor } \\
\text { appointments. " "In the future, (I } \\
\text { would like) driving lessons, same } \\
\text { teacher. Maybe make me for } \\
\text { problems for her with my children } \\
\text { - help me all the time. " }\end{array}$ & \\
\hline
\end{tabular}




\begin{tabular}{|c|c|c|}
\hline Survey One for Tutors & Survey Two for Tutors & Changes \\
\hline $\begin{array}{l}\text { 1. Thinks teaching English will be } \\
\text { difficult. }\end{array}$ & $\begin{array}{l}\text { 1. Teaching English was not } \\
\text { difficult. }\end{array}$ & + \\
\hline $\begin{array}{l}\text { 2. Feels comfortable with people } \\
\text { who do not speak English. }\end{array}$ & $\begin{array}{l}\text { 2. Feels comfortable with people } \\
\text { who do not speak English. }\end{array}$ & + \\
\hline $\begin{array}{l}\text { 3. Feels comfortable entering a } \\
\text { Somali household. }\end{array}$ & $\begin{array}{l}\text { 3. Feels comfortable entering a } \\
\text { Somali household. }\end{array}$ & \\
\hline $\begin{array}{l}\text { 4. Cannot read or write in anotier } \\
\text { language. }\end{array}$ & $\begin{array}{l}\text { 4. Cannot read or write in another } \\
\text { language. }\end{array}$ & \\
\hline $\begin{array}{l}\text { 5. Hopes to become friends with } \\
\text { student. }\end{array}$ & 5. Became friends with student. & + \\
\hline $\begin{array}{l}\text { 6. Does not plan to spend more than } \\
\text { one hour a day preparing lessons. }\end{array}$ & $\begin{array}{l}\text { 6. Did not spend more than one hour } \\
\text { a day preparing lessous. }\end{array}$ & \\
\hline $\begin{array}{l}\text { 7. Does not have experience training } \\
\text { someone to fill out a job application. }\end{array}$ & $\begin{array}{l}\text { 7. ESL training at I FS was not } \\
\text { adeguate. }\end{array}$ & - \\
\hline $\begin{array}{l}\text { 8. Has not worked with refugees } \\
\text { before. }\end{array}$ & $\begin{array}{l}\text { 8. Literacy training at L.FS was not } \\
\text { adequate. }\end{array}$ & - \\
\hline 9. Has not been to Africa. & $\begin{array}{l}\text { 9. Cultural training at LFS was } \\
\text { adequate. }\end{array}$ & \\
\hline \multirow[t]{7}{*}{$\begin{array}{l}\text { 10. Does not liave ESL tutoring } \\
\text { experience. }\end{array}$} & $\begin{array}{l}\text { 10. Received adequate support from } \\
\text { LFS staff. }\end{array}$ & \\
\hline & $\begin{array}{l}\text { 11. Student studied outside of } \\
\text { tutoring session. }\end{array}$ & + \\
\hline & $\begin{array}{l}\text { 12. Student achieved all of her } \\
\text { goals. }\end{array}$ & + \\
\hline & $\begin{array}{l}\text { 13. Liked the program's cause. } \\
\text { "Confidence and support builder for } \\
\text { refugees women. Also made } \\
\text { friendship." }\end{array}$ & + \\
\hline & 14. Liked the program's content. & + \\
\hline & $\begin{array}{l}\text { 15. Wants to continue as a tutor. "If } \\
\text { possible." }\end{array}$ & + \\
\hline & $\begin{array}{l}\text { 16. Suggestions for other LFS } \\
\text { programs: driving lessons, getting a } \\
\text { car, transportation. }\end{array}$ & \\
\hline
\end{tabular}


Identification Name: 190

Tutoring Hours Completed: 56 hours (78\% of 72 hours)

First Test: $\quad 10 / 2 / 99$

Second Test: $\quad 6 / 29 / 00$

\begin{tabular}{|c|c|c|c|c|c|c|}
\hline 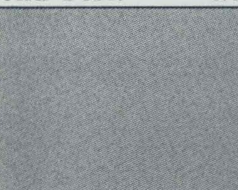 & $\begin{array}{l}\text { BEST - } \\
\frac{\text { Short }}{\text { Form }} \\
\text { SCORE }\end{array}$ & $\begin{array}{l}\text { Total } \\
\text { Points } \\
\text { Possible }\end{array}$ & $\begin{array}{l}\text { BEST } \\
\text { Short } \\
\text { Form } \\
\text { Adjusted } \\
\text { SCORE }\end{array}$ & $\frac{\frac{\text { BEST- }}{\text { Long Form }}}{\text { SCORE }}$ & $\begin{array}{l}\text { Total } \\
\text { Points } \\
\text { Possible }\end{array}$ & Changes \\
\hline Total & 6 & 40 & $13 \mathrm{II}$ & 16 III & 91 & +3 \\
\hline Communication & 0 & 22 & --------- & 9 & 48 & \\
\hline Fluency & 6 & 18 & -----o--- & 3 & 24 & \\
\hline Listening & - - & - -------- & ---------- & 4 & 11 & \\
\hline Reading/writing & - & --------- & - -------- & 0 & 12 & \\
\hline Alphabet Test & 0 & 41 & ---------- & 25 & 41 & Improve, \\
\hline Form Test & Nothing & Perfect & - - & Nothing & Perfect & \\
\hline
\end{tabular}

COMMENTS ON PARTICULAR TEST QUESTIONS

\begin{tabular}{|c|c|c|}
\hline & $\begin{array}{l}\text { Before - BEST Short } \\
\text { Form }\end{array}$ & After-BEST Long Form \\
\hline $\begin{array}{l}\text { Greetings, Personal } \\
\text { Information }\end{array}$ & $\begin{array}{l}\text { 1.-5. Missed one, } \\
\text { cannot spell. }\end{array}$ & $1,-8$ \\
\hline Describe Common Situation & 6. Home situation. & $9 .-10$ \\
\hline Time/Numbers & 7. Time: & 11. -13 . Time recognition. \\
\hline & 8. Time get up. & 14. Time get up. \\
\hline Directions, Clarification & $9 .-16$ & $\begin{array}{l}\text { 15. }-22 \text {. Cannot give all } \\
\text { directions. }\end{array}$ \\
\hline Money & $\begin{array}{l}\text { 11. Doesn't recognize } \\
\text { money. }\end{array}$ & 23. -26 Doesn't know money. \\
\hline Shopping, Food, Clothing & $\begin{array}{l}\text { 10. } 12 . \text { Camot ask for } \\
\text { prices. }\end{array}$ & $27 .-28$ \\
\hline Signs & & 29, -32 , Can read 2 of 4 signs. \\
\hline $\begin{array}{l}\text { Emergencies, Safety Health, } \\
\text { Body Parts }\end{array}$ & 13.-15. Missed one. & $33,-41$ \\
\hline Employment, Training & 18. & 42. -45 \\
\hline
\end{tabular}

LONG FORM

46-49 Form -0 of 8 pts. Name only

Alphabet

Before

Small: abABCDE

Capital: ------ 
Form

\begin{tabular}{|l|l|l|}
\hline Before & After & RESULT \\
\hline 3. No full name: & 3. No full name: & \\
\hline 4. No date of birth. & 4. No date of birth. & \\
\hline 5. No address. & 5. No address. & \\
\hline 6. No phone number & 6. No phone number. & \\
\hline 7. No household size. & 7. No household size. \\
\hline 8. No information checked off. & 8. No information checked- off: & \\
\hline 9. No children's names, no ages, no & $\begin{array}{l}\text { 9. No children's names, no ages, } \\
\text { gender. no gender }\end{array}$ \\
\hline
\end{tabular}

\begin{tabular}{|c|c|c|}
\hline $\begin{array}{l}\text { Survey One for Somali } \\
\text { Women }\end{array}$ & Survey Two for Somali Women & Changes \\
\hline A. Print none. & A. Print - none. & - \\
\hline $\begin{array}{l}\text { B. 1. Thinks learning English } \\
\text { will be difficult. }\end{array}$ & $\begin{array}{l}\text { B. 1. Thinks learning English was } \\
\text { difficult. }\end{array}$ & \\
\hline $\begin{array}{l}\text { 2. Cannot read and write in } \\
\text { Somali. }\end{array}$ & 2. Cannot read and write in Somali. & \\
\hline 3. Cannot read in English & 3. Cammot read in English. & \\
\hline $\begin{array}{l}\text { 4. Cannot write the alphabet in } \\
\text { English. }\end{array}$ & 4. Can write the alphabet in English. & + \\
\hline $\begin{array}{l}\text { 5. Cannot write sentences in } \\
\text { English. }\end{array}$ & 5. Cannot write sentences in English. & \\
\hline $\begin{array}{l}\text { 6. Camnot speak on the phone in } \\
\text { English. }\end{array}$ & $\begin{array}{l}\text { 6. Camnot speak on the phone in } \\
\text { English. }\end{array}$ & \\
\hline $\begin{array}{l}\text { 7. Cannot fill out a job } \\
\text { application in English. }\end{array}$ & $\begin{array}{l}\text { 7. Camiot fill out a job application in } \\
\text { English. }\end{array}$ & \\
\hline $\begin{array}{l}\text { 8. Has family encouragement to } \\
\text { learn English. }\end{array}$ & $\begin{array}{l}\text { 8. Had family encouragement to learn } \\
\text { English. }\end{array}$ & \\
\hline $\begin{array}{l}\text { 9. Plans to spend more than } 1 \\
\text { hour a day studying. }\end{array}$ & $\begin{array}{l}\text { 9. Spent more and } 1 \text { hour a day } \\
\text { studying - also with TV. }\end{array}$ & + \\
\hline $\begin{array}{l}\text { 10. Looking forward to meeting } \\
\text { tutor. }\end{array}$ & 10. Tutor became a friend. & ++ \\
\hline $\begin{array}{l}\text { 11. Studied English in the US at } \\
\text { PCC for } 4 \text { months. }\end{array}$ & 11. Tutor was a good teacher. & ++ \\
\hline $\begin{array}{l}\text { C. Goals are "to be able to } \\
\text { communicate." }\end{array}$ & 12. Did not achieve goals & - \\
\hline
\end{tabular}




\begin{tabular}{|c|c|c|}
\hline Survey One for Tutors & Survey Two for Tutors & Changes \\
\hline $\begin{array}{l}\text { 1. Thinks teaching English will be } \\
\text { difficult. }\end{array}$ & 1. Teaching English was difficult. & \\
\hline $\begin{array}{l}\text { 2. Feels comfortable with people } \\
\text { who do not speak English. }\end{array}$ & $\begin{array}{l}\text { 2. Feels comfortable with people } \\
\text { who do not speak English. }\end{array}$ & \\
\hline $\begin{array}{l}\text { 3. Feels comfortable entering a } \\
\text { Somali household. }\end{array}$ & $\begin{array}{l}\text { 3. Feels comfortable entering a } \\
\text { Somali household. }\end{array}$ & \\
\hline $\begin{array}{l}\text { 4. Can read or write in another } \\
\text { language. }\end{array}$ & $\begin{array}{l}\text { 4. Can read or write in another } \\
\text { language. }\end{array}$ & \\
\hline $\begin{array}{l}\text { 5. Hopes to become friends with } \\
\text { student. }\end{array}$ & 5. Became friends with student. & \\
\hline $\begin{array}{l}\text { 6. Does not plan to spend more } \\
\text { than one hour a day preparing } \\
\text { lessons. }\end{array}$ & $\begin{array}{l}\text { 6. Did not spend more than one } \\
\text { hour a day preparing lessons. }\end{array}$ & \\
\hline $\begin{array}{l}\text { 7. Does not have experience } \\
\text { training someone to fill out a job } \\
\text { application. }\end{array}$ & 7. ESL training was adequate. & \\
\hline $\begin{array}{l}\text { 8. Has worked with refugees } \\
\text { before. }\end{array}$ & $\begin{array}{l}\text { 8. Literacy teaching training from } \\
\text { LFS was adequate. }\end{array}$ & ++ \\
\hline $\begin{array}{l}\text { 9. Has been to Africa - West } \\
\text { Africa, } 31 / 2 \text { years, Peace Corps. }\end{array}$ & $\begin{array}{l}\text { 9. Cultural training at LFS was } \\
\text { adequate. }\end{array}$ & ++ \\
\hline \multirow[t]{7}{*}{$\begin{array}{l}\text { 10. Has no ESL tutoring } \\
\text { experience. }\end{array}$} & $\begin{array}{l}\text { 10. Received adequate support } \\
\text { from LFS staff. }\end{array}$ & ++ \\
\hline & $\begin{array}{l}\text { 11. Student did homework outside } \\
\text { of tutoring session. }\end{array}$ & ++ \\
\hline & $\begin{array}{l}\text { 12. Student did not achieve her } \\
\text { goals: }\end{array}$ & \\
\hline & $\begin{array}{l}\text { 13. Liked the program's cause. "It } \\
\text { served a purpose." }\end{array}$ & ++ \\
\hline & $\begin{array}{l}\text { 14. Liked the program's content. } \\
\text { "I like it. This program is good. } \\
\text { It's fun. When she goes to the } \\
\text { street, she can't ask questions by } \\
\text { herself. I made vocabulary } \\
\text { practice sheets." }\end{array}$ & ++ \\
\hline & 15. Wants to continue as a tutor. & \\
\hline & $\begin{array}{l}\text { 16. Suggestions for other LFS } \\
\text { programs: none. }\end{array}$ & \\
\hline
\end{tabular}


Identification Name: 200

$1 / 3$

Tutoring Hours Completed: 12 hours (17\% of 72 hours)

$\begin{array}{ll}\text { First Test: } & 9 / 16 / 99 \\ \text { Second Test: } & 4 / 27 / 00\end{array}$

\begin{tabular}{|c|c|c|c|c|c|c|}
\hline & $\begin{array}{l}\text { BEST -Short } \\
\text { Form SCORE }\end{array}$ & $\begin{array}{l}\text { Total } \\
\text { Points } \\
\text { Possible }\end{array}$ & $\begin{array}{l}\text { BEST } \\
\text { Short } \\
\text { Form } \\
\text { Adjusted } \\
\text { SCORE }\end{array}$ & $\begin{array}{l}\text { BEST-Long } \\
\begin{array}{l}\text { Form } \\
\text { SCORE }\end{array}\end{array}$ & $\begin{array}{l}\text { Total } \\
\text { Points } \\
\text { Possible }\end{array}$ & Changes \\
\hline Total & 28 & 40 & $55 \mathrm{VII}$ & $58 \mathrm{VII}$ & 91 & +3 \\
\hline Communication & 20 & 22 & --------- & 38 & 48 & \\
\hline Fluency & 8 & 18 & - & 12 & 24 & \\
\hline Listening & - - & - --- & - --o- & 8 & 11 & \\
\hline Reading/writing & - ------ & -------- & --------- & 10 & 12 & \\
\hline Alphabet Test & 12 & 41 & --------- & 32 & 41 & Improve \\
\hline Form Test & $\begin{array}{l}\text { Perfect except } \\
\text { missing } \\
\text { household size, } \\
\text { children's ages } \\
\text { and sex }\end{array}$ & Perfect & --------- & $\begin{array}{l}\text { Better- } \\
\text { perfect } \\
\text { except } \\
\text { missing } \\
\text { children's } \\
\text { ages and sex } \\
\text { and date }\end{array}$ & Perfect & Improve \\
\hline
\end{tabular}

COMMENTS ON PARTICULAR TEST QUESTIONS

\begin{tabular}{|c|c|c|}
\hline & Before - BEST Short Form & After-BEST Long Form \\
\hline Greetings, Personal Information & 1.-5. Missed one. & 1. -8 . \\
\hline Describe Common Situation & 6. Home situation. & 9. -10 . \\
\hline Time/Numbers & 7. Time. & 11.-13. Time recognition. \\
\hline & 8. Time get up perfect. & 14. Time get up. \\
\hline Directions, Clarification & 9. -16 . & $\begin{array}{l}\text { 15. }-23 \text { Cannot give all } \\
\text { directions. }\end{array}$ \\
\hline Money & 11. Does recognize money. & 24. -16 Does know money. \\
\hline Shopping, Food, Clothing & 10., 12. Can ask for prices. & 27. -28. Can ask for prices. \\
\hline Signs & & $\begin{array}{l}29 .-32 . \text { Can read } 3 \text { of } 4 \\
\text { signs. }\end{array}$ \\
\hline $\begin{array}{l}\text { Emergencies, Safety Health, Body } \\
\text { Parts }\end{array}$ & 13. -15 . Missed one. & 33. -41 . \\
\hline Employment, Training & 18. & $42 .-45$ \\
\hline
\end{tabular}


LONG FORM

46-49 Form -7 of 8 pts. Address is missing the city, state and zip

Before

Small: abCDEFGHmApJKtLMyN

Capital: AOBKGRSMTPYVWYXWZ AbcdEEFGHIJKLMNOPKRSTUVWXYZ

\section{Alphabet}

After

abcdEFGHIJKImNopkrstuvwxyz

Form

\begin{tabular}{|l|l|c|}
\hline Before & After & RESULT \\
\hline 3. Full name. & 3. Full name. & + \\
\hline 4. Year only. & 4. Full date of birth. & \\
\hline 5. Missing city and state. & 5. Good address "Portlan." & \\
\hline 6. Phone number. & 6. Phone number. & + \\
\hline $\begin{array}{l}\text { 7. No household size. } \\
\text { 8. No information checked off: }\end{array}$ & 7. Household size. & \\
\hline $\begin{array}{l}\text { 9. Children's names only, no ages, no } \\
\text { gender. }\end{array}$ & 8. Information checked off. \\
\hline 10. Signature and date. & 10. Signature, no date. & \\
\hline
\end{tabular}

\begin{tabular}{|c|c|c|}
\hline Survey One for Somali Women & Survey Two for Somali Women & Changes \\
\hline $\begin{array}{l}\text { A. Print at home - homework, } \\
\text { letters/mail, checking prices and } \\
\text { finding the right aisle. }\end{array}$ & A. Print-none. & - \\
\hline $\begin{array}{l}\text { B. 1. Thinks learning English will be } \\
\text { not difficult. }\end{array}$ & $\begin{array}{l}\text { B. 1. Thinks learning English was not } \\
\text { difficult. }\end{array}$ & \\
\hline 2. Can read and write in Somali. & 2. Can read and write in Somali. & \\
\hline $\begin{array}{l}\text { 3. Can read in English - beginning } \\
\text { level. }\end{array}$ & $\begin{array}{l}\text { 3. Can read in English -intermediate } \\
\text { level. }\end{array}$ & + \\
\hline 4. Can write the alphabet in English. & 4. Can write the alphabet in English. & \\
\hline $\begin{array}{l}\text { 5. Can write sentences in English - } \\
\text { basic 3-5 words. }\end{array}$ & $\begin{array}{l}\text { 5. Can write sentences in English - basic } \\
\text { sentences } 3-5 \text { words. }\end{array}$ & + \\
\hline 6. Can speak on the phone in English. & $\begin{array}{l}\text { 6. Cannot speak on the phone in } \\
\text { English. }\end{array}$ & - \\
\hline $\begin{array}{l}\text { 7. Cannot fill out a job application in } \\
\text { English. }\end{array}$ & $\begin{array}{l}\text { 7. Cannot hill out a job application in } \\
\text { Enghish. }\end{array}$ & \\
\hline $\begin{array}{l}\text { 8. Has family encouragement to learn } \\
\text { English. }\end{array}$ & $\begin{array}{l}\text { 8. Had family encouragement to learn } \\
\text { English. }\end{array}$ & ++ \\
\hline $\begin{array}{l}\text { 9. Plans to spend more than } 1 \text { hour a } \\
\text { day studying. }\end{array}$ & $\begin{array}{l}\text { 9. Spent more and } 1 \text { hour a day studying } \\
\text { - also with TV. }\end{array}$ & + \\
\hline 10. Looking forward to meeting tutor. & 10. Tutor became a friend. & + \\
\hline $\begin{array}{l}\text { 11. Studied English in the US at PCC } \\
\text { for } 4 \text { months. }\end{array}$ & 11. Tutor was a good teacher. & + \\
\hline C. Goals are "to go to the university." & $\begin{array}{l}\text { 12. Did not achieve goals. "Only a litile } \\
\text { bil. I would like to learn how to drive" }\end{array}$ & - \\
\hline
\end{tabular}




\begin{tabular}{|c|c|c|}
\hline Survey One for Tutors & Survey Two for Tutors & Changes \\
\hline $\begin{array}{l}\text { 1. Thinks teaching English will } \\
\text { be difficult }\end{array}$ & 1. Teaching English was not difficult. & + \\
\hline $\begin{array}{l}\text { 2. Feels comfortable with } \\
\text { people who do not speak } \\
\text { English. }\end{array}$ & $\begin{array}{l}\text { 2. Feels comfortable with people who do not } \\
\text { speak English. }\end{array}$ & \\
\hline $\begin{array}{l}\text { 3. Feels comfortable entering a } \\
\text { Somali household. }\end{array}$ & $\begin{array}{l}\text { 3. Doesn't feel comfontable entering a Somali } \\
\text { household }\end{array}$ & - \\
\hline $\begin{array}{l}\text { 4. Can read or write in another } \\
\text { language. }\end{array}$ & 4. Can read or write in another language. & \\
\hline $\begin{array}{l}\text { 5. Hopes to become friends with } \\
\text { student. }\end{array}$ & 5. Became friends with student. & + \\
\hline $\begin{array}{l}\text { 6. Does not plan to spend more } \\
\text { than one hour a day preparing } \\
\text { lessons. }\end{array}$ & $\begin{array}{l}\text { 6. Did not spend more than one hour a day } \\
\text { preparing lessons. }\end{array}$ & \\
\hline $\begin{array}{l}\text { 7. Has experience training } \\
\text { someone to fill out a job } \\
\text { application. }\end{array}$ & 7. ISL training was not adequate. & -- \\
\hline $\begin{array}{l}8 \text { Has not worked with refugees } \\
\text { before. }\end{array}$ & $\begin{array}{l}\text { 8. Literacy teaching training from LFS was } \\
\text { adequate. }\end{array}$ & ++ \\
\hline 14. Has not been to Africa. & 9. Cultural training at LFS was adequate. & ++ \\
\hline \multirow{7}{*}{$\begin{array}{l}\text { 10. Has no ESL tutoring } \\
\text { experience. }\end{array}$} & 10. Received adequate support from LFS staff. & ++ \\
\hline & $\begin{array}{l}\text { 11. Student did homework outside of tutoring } \\
\text { session. }\end{array}$ & ++ \\
\hline & 12. Student did not aclieve her goals. & \\
\hline & $\begin{array}{l}\text { 13. Liked the program's cause. "It served a } \\
\text { purpose." }\end{array}$ & ++ \\
\hline & $\begin{array}{l}\text { 14. Liked the program's content. "I think a } \\
\text { little less formality would have been nice." }\end{array}$ & ++ \\
\hline & 15. Does not Want to continite as a tutor. & \\
\hline & $\begin{array}{l}\text { 16. Suggestions for other LFS programs: "Can } \\
\text { have meetings in a community room in a local } \\
\text { mosque." }\end{array}$ & \\
\hline
\end{tabular}


Identification Name: 210

Tutoring Hours Completed: 72 hours (100\% of 72 hours)

First Test: 9/20/99

Second Test: $8 / 26 / 00$

\begin{tabular}{|c|c|c|c|c|c|c|}
\hline & $\frac{\frac{\text { BEST - }}{\text { Short Form }}}{\text { SCORE }}$ & $\begin{array}{l}\text { Total } \\
\text { Points } \\
\text { Possible }\end{array}$ & $\begin{array}{l}\text { BEST } \\
\text { Short } \\
\text { Form } \\
\text { Adjusted } \\
\text { SCORE }\end{array}$ & $\frac{\frac{\text { BEST- }}{\text { Long Form }}}{\text { SCORE }}$ & $\begin{array}{l}\text { Total } \\
\text { Points } \\
\text { Possible }\end{array}$ & Changes \\
\hline Total & 36 & 40 & $70 \mathrm{VII}$ & $76 \mathrm{VII}$ & 94 & +6 \\
\hline Communication & 22 & 22 & --------- & 44 & 48 & \\
\hline Fluency & 14 & 18 & ---------- & 23 & 24 & \\
\hline Listening & 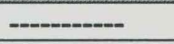 & 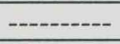 & - -.-.-- & 9 & 11 & \\
\hline Reading/writing & - - - & --------- & --------- & 12 & 12 & \\
\hline Alphabet Test & 28 & 41 & --------- & 35 & 41 & $\begin{array}{l}\text { Improvem } \\
\text { ent }\end{array}$ \\
\hline Form Test & Perfect & Perfect & --------- & Perfect & Perfect & Same \\
\hline
\end{tabular}

\section{COMMENTS ON PARTICULAR TEST QUESTIONS}

\begin{tabular}{|c|c|c|}
\hline & Before - BEST Short Form & After-BEST Long Form \\
\hline $\begin{array}{l}\text { Greetings, Personal } \\
\text { Information }\end{array}$ & 1. -5. Missed one. & 1. -8. Missed one. \\
\hline Describe Common Situation & 6. Home situation. & 9. -10 . \\
\hline Time/Numbers & 7. Time. & 11. -13 . Time recognition. \\
\hline & 8. Time get up perfect. & 14. Time get up. \\
\hline Directions, Clarification & 9. -16. Missed one. & $\begin{array}{l}\text { 15. - } 23 \text { Can give all directions- } \\
\text { Missed one on question } \\
\text { formation. }\end{array}$ \\
\hline Money & 11. Does recognize money. & 24. -16 Does know money. \\
\hline Shopping, Food, Clothing & 10., 12. Can ask for prices. & 27. -28.Can ask for prices. \\
\hline Signs & & 29. -32 . Can all 4 signs. \\
\hline $\begin{array}{l}\text { Emergencies, Safety Health, } \\
\text { Body Parts }\end{array}$ & 13. -15 . & 33. -41 \\
\hline Employment, Training & 18. & 42. -45 \\
\hline
\end{tabular}


Alphabet

\section{Before}

Small: abcDEFGHijkLmNopqRstuvwxyz

abcDDefGHijklmNopQrstuvwxyz

Capital: AbCDEFGHiJKLMNOPqRSTUVWXYZ ABCEFGHIJKLMNOPQRSTUVWXYZ

Form

\begin{tabular}{|l|l|l|}
\hline Before & After & RESULT \\
\hline 3. Full name. & 3. Full name. & \\
\hline 4. Date of Birth. & 4. Date of Birth. & \\
\hline 5. Full address. & 5. Full address. & \\
\hline 6. Full phone number. & 6. Full phone number. & \\
\hline 7. Household size. & 7. Household size. & \\
\hline 8. Services checked. & 8. Services checked. & \\
\hline 9. 2 children's names and full info & 9.2 children's names and full info. & \\
\hline 10. Signature and date. & & \\
& 10. Signature and date. & \\
\hline
\end{tabular}

\begin{tabular}{|c|c|c|}
\hline Survey One for Somali Women & Survey Two for Somali Women & Changes \\
\hline A. Print - Bills. & A. Print - Children's Books. & ++ \\
\hline B. 1. Thinks learning English will be difficult & $\begin{array}{l}\text { B. 1. Thinks learning English was } \\
\text { not difficult. }\end{array}$ & + \\
\hline 2. Camnot read and write in Somali. & $\begin{array}{l}\text { 2. Cannot read and write in } \\
\text { Somali. }\end{array}$ & \\
\hline 3. Can read in English - intermediate level. & $\begin{array}{l}\text { 3. Can read in English - advanced } \\
\text { level. }\end{array}$ & + \\
\hline 4. Can write the alphabet in English. & $\begin{array}{l}\text { 4. Can write the alphabet in } \\
\text { English. }\end{array}$ & \\
\hline 5. Can't write sentences in English. & $\begin{array}{l}\text { 5. Can write sentences in English - } \\
\text { long - more than } 5 \text { words. }\end{array}$ & + \\
\hline 6. Can speak on the phone in English. & $\begin{array}{l}\text { 6. Can speak on the phone in } \\
\text { English. }\end{array}$ & \\
\hline $\begin{array}{l}\text { 7. Camnot fill out a job application in } \\
\text { English. }\end{array}$ & $\begin{array}{l}\text { 7. Can fill out a job application in } \\
\text { English. }\end{array}$ & + \\
\hline $\begin{array}{l}\text { 8. Has family encouragement to learn } \\
\text { English. }\end{array}$ & $\begin{array}{l}\text { 8. Had family encouragement to } \\
\text { learn English. }\end{array}$ & ++ \\
\hline $\begin{array}{l}\text { 9. Plans to spend more than } 1 \text { hour a day } \\
\text { studying. }\end{array}$ & $\begin{array}{l}\text { 9. Did spend more than } 1 \text { hour a } \\
\text { day studying. }\end{array}$ & ++ \\
\hline 10. Looking forward to meeting tutor. & 10. Tutor became a friend. & ++ \\
\hline 11. Did not study English in the US. & $\begin{array}{l}\text { 11. Tutor was a good teacher. "I } \\
\text { like her and she is my best friend." }\end{array}$ & \\
\hline $\begin{array}{l}\text { C. Goals are "I would like to train as a } \\
\text { nurse." }\end{array}$ & $\begin{array}{l}\text { 12. Achieved goals. "How to read } \\
\text { and to do math." "I would like help } \\
\text { to finish my GED." }\end{array}$ & \\
\hline
\end{tabular}




\begin{tabular}{|c|c|c|}
\hline Survey One for Tutors & Survey Two for Tutors & Changes \\
\hline $\begin{array}{l}\text { 1. Thinks teaching English } \\
\text { will not be difficult. }\end{array}$ & 1. Teaching English was not difficult. & \\
\hline $\begin{array}{l}\text { 2. Does not feel comfortable } \\
\text { with people who da not speal } \\
\text { English. }\end{array}$ & $\begin{array}{l}\text { 2. Does not feel comfortable with people who do } \\
\text { not speak English. }\end{array}$ & \\
\hline $\begin{array}{l}\text { 3. Does not feel comfortable } \\
\text { entering a Somali household. }\end{array}$ & $\begin{array}{l}\text { 3. Feels comfortable entering a Somali } \\
\text { household. }\end{array}$ & + \\
\hline $\begin{array}{l}\text { 4. Camnot read or write in } \\
\text { another language. }\end{array}$ & 4. Cannot read or write in another language. & \\
\hline $\begin{array}{l}\text { 5. Hopes to become friends } \\
\text { with student. }\end{array}$ & 5. Became friends with student. & + \\
\hline $\begin{array}{l}\text { 6. Plans to spend more than } \\
\text { one hour a day preparing } \\
\text { lessons. }\end{array}$ & $\begin{array}{l}\text { 6. Did not spend more than one hour a day } \\
\text { preparing lessons. }\end{array}$ & + \\
\hline $\begin{array}{l}\text { 7. Has experience training } \\
\text { someone to fill out a job } \\
\text { application. }\end{array}$ & 14. ESL training at LFS was adequate. & ++ \\
\hline $\begin{array}{l}\text { 8. Has not worked with } \\
\text { refugees before. }\end{array}$ & 8. Literacy training at LFS was adequate. & ++ \\
\hline 15. Has not been to Africa. & 9. Cultural training at LFS was adequate. & ++ \\
\hline \multirow[t]{7}{*}{$\begin{array}{l}\text { 10. Has ESL tutoring } \\
\text { experience "Local woman } \\
\text { who was from Peru and was } \\
\text { uncertain of her skills." }\end{array}$} & 10. Received adequate support from LFS staff. & ++ \\
\hline & $\begin{array}{l}\text { 11. Student did not study outside of tutoring } \\
\text { sessions. }\end{array}$ & - \\
\hline & 12. Student achieved her goals. & + \\
\hline & 13. Liked the program's cause. & + \\
\hline & 14. Liked the program's content. & + \\
\hline & 15. Wants to continue as a tutor. "If possible." & + \\
\hline & $\begin{array}{l}\text { 16. Suggestions for other LFS programs: "The } \\
\text { next step is the kids - to help them with } \\
\text { academics." Comments: "We tried to have get- } \\
\text { togethers with the tutors. It was difficult." "She's } \\
\text { been through hell and high-water and she has no } \\
\text { wrinkles." "Comfortable with non-English } \\
\text { speakers as long as I have my hearing aids in. I } \\
\text { don't hear consonants." }\end{array}$ & \\
\hline
\end{tabular}


Identification Name: 220

Tutoring Hours Completed: 42 hours (58\% of 72 hours)

First Test: $\quad$ 9/19/99

Second Test: $\quad 6 / 17 / 00$

\begin{tabular}{|c|c|c|c|c|c|c|}
\hline & $\frac{\frac{\text { BEST - }}{\text { Short Form }}}{\text { SCORE }}$ & $\begin{array}{l}\text { Total } \\
\text { Points } \\
\text { Possible }\end{array}$ & $\begin{array}{l}\text { BEST } \\
\text { Short } \\
\text { Form } \\
\text { Adjusted } \\
\text { SCORE }\end{array}$ & $\frac{\frac{\text { BEST- }}{\text { Long Form }}}{\text { SCORE }}$ & $\begin{array}{l}\text { Total } \\
\text { Points } \\
\text { Possible }\end{array}$ & Changes \\
\hline Total & 17 & 40 & $34 V I I$ & 57 VII & 91 & +23 \\
\hline $\begin{array}{l}\text { Communicat } \\
\text { ion }\end{array}$ & 14 & 22 & ---------- & 39 & 48 & \\
\hline Fluency & 3 & 18 & - - - & 13 & 24 & \\
\hline Listening & -------- & --------- & --------- & 5 & 11 & \\
\hline $\begin{array}{l}\text { Reading/writ } \\
\text { ing }\end{array}$ & 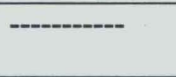 & --------- & ---------- & 8 & 12 & \\
\hline $\begin{array}{l}\text { Alphabet } \\
\text { Test }\end{array}$ & 3 & 41 & --------- & 4 & 41 & $\begin{array}{l}\text { Improve, } \\
\text { more } \\
\text { letters } \\
\text { demon- } \\
\text { strated }\end{array}$ \\
\hline Form Test & $\begin{array}{l}\text { Full name, } \\
\text { partial } \\
\text { address } \\
\text { missing the } \\
\text { street, } \\
\text { phone } \\
\text { number }\end{array}$ & Perfect & --------- & $\begin{array}{l}\text { Better Full } \\
\text { name, full } \\
\text { address, } \\
\text { phone } \\
\text { number, } \\
\text { houseold } \\
\text { size, }\end{array}$ & Perfect & Improve \\
\hline
\end{tabular}

\section{COMMENTS ON PARTICULAR TEST QUESTIONS}

\begin{tabular}{|c|c|c|}
\hline & $\begin{array}{l}\text { Before - BEST Short } \\
\text { Form }\end{array}$ & After-BEST Long Form \\
\hline Greetings, Personal Information & 1. -5 . Missed one. & 1. -8 . Missed one. \\
\hline Describe Common Situation & 6. Home situation. & 9. -10 \\
\hline Time/Numbers & 7. T.ime: & 11. - 13. Time recognition. \\
\hline & 8. Time get up perfect. & 14. Time get up. \\
\hline Directions, Clarification & 9. -16 . & 15. -23 Cannot give all directions \\
\hline Money & 11. Does recognize money. & 24. -26. Does know money. \\
\hline Shopping, Food, Clothing & 10. 12. Can't ask for prices & 27. -28.Can ask for prices. \\
\hline Signs & & 29. -32 . Can read 2 of 4 signs. \\
\hline $\begin{array}{l}\text { Emergencies, Safety Health, } \\
\text { Body Parts }\end{array}$ & 13. -15 . & 33. -41 \\
\hline Employment, Training & 18. & 42. -45 Missed one. \\
\hline
\end{tabular}




\section{LONG FORM}

46-49 Form -6 of 8pts. Didn't add

signature- everything else is perfect

\section{Alphabet}

\section{Before}

Small: abcdEF

Capital: nothing

After
abcDEFHJKLmmNNSpowyz
nothing

\section{Form}

\begin{tabular}{|l|l|c|}
\hline Before & After & RESULT \\
\hline 3. First and last name. & 3. Full name with middle name. & + \\
\hline $\begin{array}{l}\text { 4. No date of birth. } \\
\text { 5. Missing street name. }\end{array}$ & $\begin{array}{l}\text { 4. No DOB- } 5545^{\text {r }} \text { was written. } \\
\text { "ORGON." }\end{array}$ & \\
\hline 6. Phone number. & 6. Phone number. & + \\
\hline 7. No household size. & 7. Household size. & \\
\hline $\begin{array}{l}\text { 8. No informaiton checked off. } \\
\text { 9. No children's names, no ages, no } \\
\text { gender. }\end{array}$ & \begin{tabular}{l} 
8. No children's names, no ages, no sex. \\
\hline 10. No signature and no date.
\end{tabular} & \\
\hline
\end{tabular}

\begin{tabular}{|c|c|c|}
\hline Survey One for Somali Women & Survey Two for Somali Women & Changes \\
\hline A. Print at home-bill. & A. Print - books, children, homework. & \\
\hline $\begin{array}{l}\text { B. 1. Thinks learning English will be } \\
\text { not difficull. }\end{array}$ & $\begin{array}{l}\text { B. 1. Thinks learing English was not } \\
\text { difficult. }\end{array}$ & \\
\hline 2. Camnot read and write in Somali & 2. Can read in Somali - not write. & + \\
\hline 3. Camot read in English. & 3. Can read in English -intermediate level. & + \\
\hline 4. Can write the alphabet in English. & 4. Can write the alphabet in English. & \\
\hline $\begin{array}{l}\text { 5. Cannot write sentences in } \\
\text { English. }\end{array}$ & 5. Camiot write sentences in English. & \\
\hline $\begin{array}{l}\text { 6. Cannot speak on the phone in } \\
\text { English. }\end{array}$ & 6. Cannot speak on the phone in English. & \\
\hline $\begin{array}{l}\text { 7. Cumnot fill out a job application in } \\
\text { English. }\end{array}$ & $\begin{array}{l}\text { 7. Cannot fill out a job application in } \\
\text { English. }\end{array}$ & \\
\hline $\begin{array}{l}\text { 8. Has family encouragement to } \\
\text { learn English. }\end{array}$ & $\begin{array}{l}\text { 8. Had family encouragement to learn } \\
\text { English. }\end{array}$ & ++ \\
\hline $\begin{array}{l}\text { 9. Does not plan to spend more than } \\
1 \text { hour a day studying. }\end{array}$ & 9. Spent more than 1 hour a day studying. & + \\
\hline $\begin{array}{l}\text { 10. Looking forward to meeting } \\
\text { tutor. }\end{array}$ & 10. Tutor became a friend. & ++ \\
\hline $\begin{array}{l}\text { 11. Studied English in the US at } \\
\text { IRCO and Steps for Success. }\end{array}$ & 11. Tutor was a good teacher. & ++ \\
\hline $\begin{array}{l}\text { C. Goals are "to communicate, to } \\
\text { talk with doctor, to talk with } \\
\text { teachers, and to talk on the phone." }\end{array}$ & $\begin{array}{l}\text { 12. Achieved goals. "I speak and } \\
\text { understand basic English now. " }\end{array}$ & + \\
\hline
\end{tabular}




\begin{tabular}{|c|c|c|}
\hline Survey One for Tutors & Survey Two for Tutors & Changes \\
\hline $\begin{array}{l}\text { 1. Thinks teaching English will be } \\
\text { difficult. }\end{array}$ & $\begin{array}{l}\text { 1. Teaching English was } \\
\text { difficult. }\end{array}$ & \\
\hline $\begin{array}{l}\text { 2. Feels comfortable with people who } \\
\text { do not speak English. }\end{array}$ & $\begin{array}{l}\text { 2. Feels comfortable with } \\
\text { people who do not speak } \\
\text { English. }\end{array}$ & \\
\hline $\begin{array}{l}\text { 3. Does not feel comfortable entering a } \\
\text { Somali household. }\end{array}$ & $\begin{array}{l}\text { 3. Feels comfortable entering a } \\
\text { Somali household. }\end{array}$ & + \\
\hline $\begin{array}{l}\text { 4. Can read or write in another language } \\
\text { - Spanish. }\end{array}$ & $\begin{array}{l}\text { 4. Can read or write in another } \\
\text { language - Spanish. }\end{array}$ & \\
\hline $\begin{array}{l}\text { 5. Hopes to become friends with } \\
\text { student. }\end{array}$ & 5. Became friends with student. & + \\
\hline $\begin{array}{l}\text { 6. Does not plan to spend more than ono } \\
\text { hour a day preparing lessons. }\end{array}$ & $\begin{array}{l}\text { 6. Did not spend more than one } \\
\text { hour a day preparing lessons. }\end{array}$ & \\
\hline $\begin{array}{l}\text { 7. Does not have experience training } \\
\text { someone to fill out a job application. }\end{array}$ & 7. ESL training was adequate. & \\
\hline 8. Has not worked with refugees before. & $\begin{array}{l}\text { 8. Literacy teaching training } \\
\text { from LFS was adequate. }\end{array}$ & \\
\hline 9. Has not been to Africa. & $\begin{array}{l}\text { 9. Cultural training at LFS was } \\
\text { adequate. }\end{array}$ & \\
\hline \multirow[t]{7}{*}{$\begin{array}{l}\text { 10. Has ESL tutoring experience. } \\
\text { Taught English at the Binnntinae Center } \\
\text { in La Paz, Bolivia. Students were } \\
\text { children and adults. }\end{array}$} & $\begin{array}{l}\text { 10. Received adequate support } \\
\text { from LFS staff. }\end{array}$ & \\
\hline & $\begin{array}{l}\text { 11. Stident did nat do } \\
\text { homework nutside of tutoring }\end{array}$ & - \\
\hline & $\begin{array}{l}\text { 12. Student did not achieve all } \\
\text { of her guals. }\end{array}$ & - \\
\hline & 13. Liked the program's cause. & ++ \\
\hline & $\begin{array}{l}\text { 14. Liked the program's } \\
\text { content. }\end{array}$ & ++ \\
\hline & $\begin{array}{l}\text { 15. Does not want to continue } \\
\text { as a tutor. "To do something } \\
\text { else." }\end{array}$ & - \\
\hline & $\begin{array}{l}\text { 16. Suggestions for other LFS } \\
\text { programs: none. }\end{array}$ & \\
\hline
\end{tabular}


Identification Name: 230

$2301 / 3$

Tutoring Hours Completed: 22 hours (31\% of 72 hours)

First Test: $\quad 10 / 29 / 99$

Second Test: $\quad 3 / 29 / 00$

\begin{tabular}{|c|c|c|c|c|c|c|}
\hline & $\begin{array}{l}\frac{\text { BEST - }}{\text { Short Form }} \\
\text { SCORE }\end{array}$ & $\begin{array}{l}\text { Total } \\
\text { Points } \\
\text { Possible }\end{array}$ & $\begin{array}{l}\text { BEST } \\
\text { Short } \\
\text { Form } \\
\text { Adjusted } \\
\text { SCORE }\end{array}$ & $\begin{array}{l}\text { BEST- } \\
\text { Long } \\
\text { Form } \\
\text { SCORE }\end{array}$ & $\begin{array}{l}\text { Total } \\
\text { Points } \\
\text { Possible }\end{array}$ & Changes \\
\hline Total & 34 & 40 & $66 \mathrm{VII}$ & 71 VII & 91 & +5 \\
\hline $\begin{array}{l}\text { Communicat } \\
\text { ion }\end{array}$ & 19 & 22 & --------- & 43 & 48 & \\
\hline Fluency & 15 & 18 & -------- & 23 & 24 & \\
\hline Listening & - ------ & - - - & - ---o--- & 5 & 11 & \\
\hline $\begin{array}{l}\text { Reading/writ } \\
\text { ing }\end{array}$ & -------- & --------- & -------- & 10 & 12 & \\
\hline $\begin{array}{l}\text { Alphabet } \\
\text { Test }\end{array}$ & 22 & 41 & ---------- & 41 & 41 & Improve \\
\hline Form Test & $\begin{array}{l}\text { Everything- } \\
\text { only } \\
\text { missing } \\
\text { children's } \\
\text { sex and ages }\end{array}$ & Perfect & --------- & $\begin{array}{l}\text { Everything } \\
\text { - only } \\
\text { missing } \\
\text { children's } \\
\text { sex }\end{array}$ & Perfect & Improve \\
\hline
\end{tabular}

\section{COMMENTS ON PARTICULAR TEST QUESTIONS}

\begin{tabular}{|c|c|c|}
\hline & $\begin{array}{l}\text { Before - BEST Short } \\
\text { Form }\end{array}$ & After-BEST Long Form \\
\hline $\begin{array}{l}\text { Greetings, Personal } \\
\text { Information }\end{array}$ & 1. -5 . Missed one. & 1.-8. \\
\hline $\begin{array}{l}\text { Describe Common } \\
\text { Situation }\end{array}$ & 6. Home situation. & $9 .-10$. \\
\hline Time/Numbers & 7. Time. & 11. -13. Time recognition. \\
\hline & 8. Time get up perfect. & 14. Time get up. \\
\hline Directions, Clarification & 9. -16 & 15. -23 Cannot give all directions. \\
\hline Money & $\begin{array}{l}\text { 11. Does recognize } \\
\text { money. }\end{array}$ & 24. -26. Does know money well. \\
\hline Shopping, Food, Clothing & $\begin{array}{l}\text { 10., 12. Can't ask for } \\
\text { prices. }\end{array}$ & 27. -28 . \\
\hline Signs & & 29. -32 . Can read 3 of 4 signs. \\
\hline $\begin{array}{l}\text { Emergencies, Safety } \\
\text { Health, Body Parts }\end{array}$ & 13. -15 & 33. -41 . \\
\hline Employment, Training & 18. & 42. -45 \\
\hline
\end{tabular}


$230 \quad 2 / 3$

\section{LONG FORM}

46-49 Form -7 of 8pts. Address is missing the city, state and zip

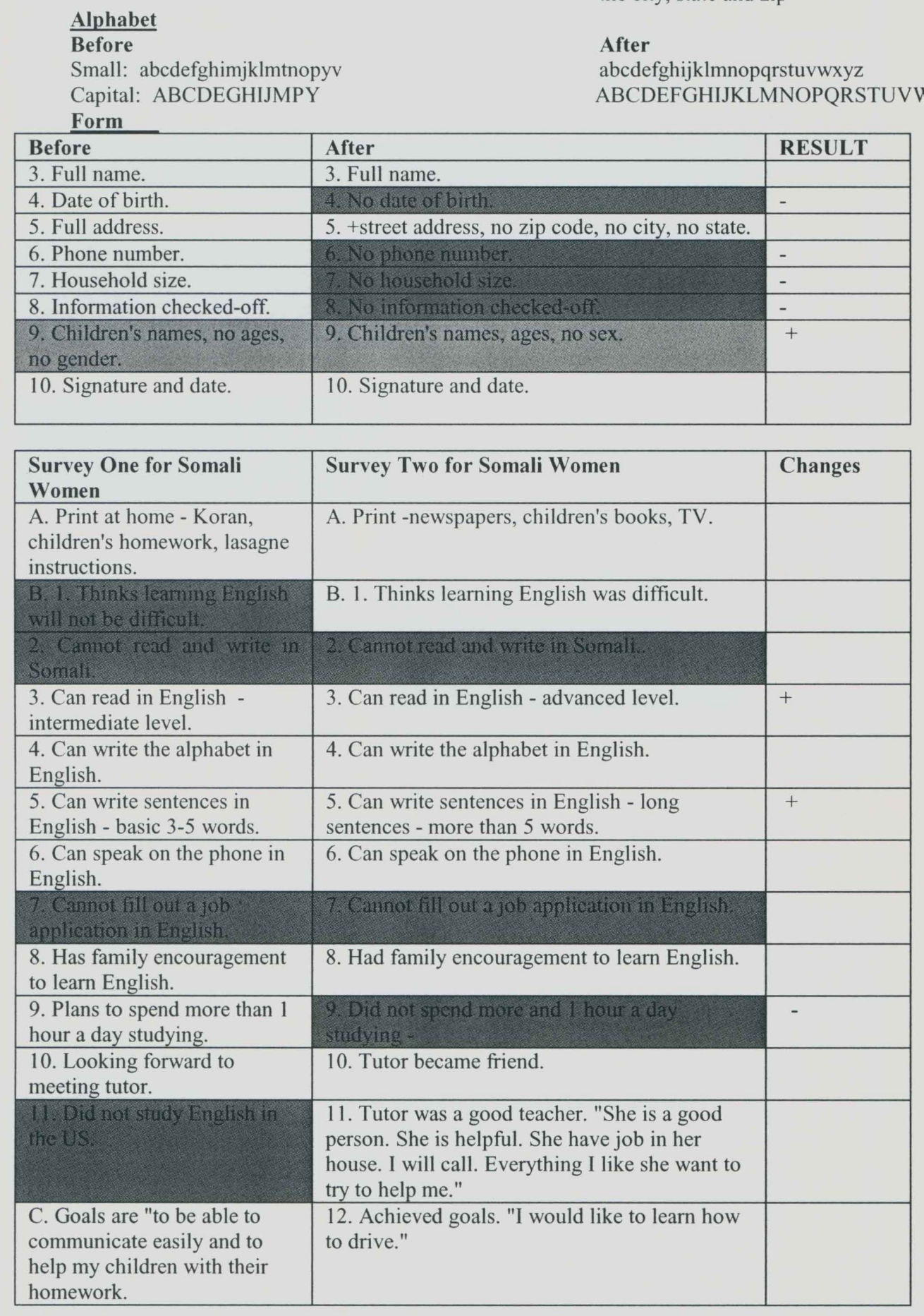




\begin{tabular}{|c|c|c|}
\hline Survey One for Tutors & Survey Two for Tutors & Changes \\
\hline $\begin{array}{l}\text { 1. Thinks teaching English will be } \\
\text { difficult. }\end{array}$ & 1. Teaching English was difficult. & \\
\hline $\begin{array}{l}\text { 2. Feels comfortable with people who } \\
\text { do not speak English. }\end{array}$ & $\begin{array}{l}\text { 2. Feels comfortable with people } \\
\text { who do not speak English. }\end{array}$ & \\
\hline $\begin{array}{l}\text { 3. Feels comfortable entering a Somali } \\
\text { household. }\end{array}$ & $\begin{array}{l}\text { 3. Feels comfortable entering a } \\
\text { Somali household. }\end{array}$ & \\
\hline 4. Camnot read or write in another & $\begin{array}{l}\text { 4. Cannot read or write in another } \\
\text { language. }\end{array}$ & \\
\hline $\begin{array}{l}\text { 5. Hopes to become friends with } \\
\text { student. }\end{array}$ & 5. Became friends with student. & + \\
\hline $\begin{array}{l}\text { 6. Does not plan to spend more than } \\
\text { one hour a day preparing lessons. }\end{array}$ & $\begin{array}{l}\text { 6. Did not spend more than one lour } \\
\text { a day preparing lessons. }\end{array}$ & \\
\hline $\begin{array}{l}\text { 7. Did not have experience training } \\
\text { someone to fill out a job application. }\end{array}$ & 7. ESL training was adequate. & ++ \\
\hline 8. Has worked with refugees before. & $\begin{array}{l}\text { 8. Literacy teaching training from } \\
\text { LFS was adequate. }\end{array}$ & ++ \\
\hline 9. Has not been to Africa. & $\begin{array}{l}\text { 9. Cultural training at LFS was } \\
\text { adequate. }\end{array}$ & ++ \\
\hline \multirow[t]{7}{*}{ 10. Has no ESI hutoring experience: } & $\begin{array}{l}\text { 10. Received adequate support from } \\
\text { LFS staff. }\end{array}$ & \\
\hline & $\begin{array}{l}\text { 11. Student did do homework } \\
\text { outside of tutoring session. }\end{array}$ & \\
\hline & $\begin{array}{l}\text { 12. Student achieved all of her } \\
\text { goals. }\end{array}$ & \\
\hline & 13. Liked the program's cause. & \\
\hline & 14. Liked the program's content. & \\
\hline & $\begin{array}{l}\text { 15. Does not wants to continue as a } \\
\text { tutor. }\end{array}$ & \\
\hline & $\begin{array}{l}\text { 16. Suggestions for LFS programs: } \\
\text { none. }\end{array}$ & \\
\hline
\end{tabular}


Identification Name: $\mathbf{2 4 0}$

Tutoring Hours Completed: 72 hours (100\% of 72 hours)
First Test:
9/19/99 Second Test:
$6 / 17 / 00$

\begin{tabular}{|c|c|c|c|c|c|c|}
\hline & $\frac{\frac{\text { BEST }}{\text { Short }}}{\frac{\text { Form }}{\text { SCORE }}}$ & $\begin{array}{l}\text { Total } \\
\text { Points } \\
\text { Possible }\end{array}$ & $\begin{array}{l}\text { BEST } \\
\text { Short } \\
\text { Form } \\
\text { Adjusted } \\
\text { SCORE }\end{array}$ & $\begin{array}{l}\text { BEST- } \\
\text { Long Form } \\
\text { SCORE }\end{array}$ & $\begin{array}{l}\text { Total } \\
\text { Points } \\
\text { Possible }\end{array}$ & Changes \\
\hline Total & 9 & 40 & $18 \mathrm{III}$ & $26 \mathrm{~V}$ & 91 & +8 \\
\hline Communication & 8 & 22 & -.-- & 16 & 48 & \\
\hline Fluency & 1 & 18 & --------- & 4 & 24 & \\
\hline Listening & - & --------- & -------- & 2 & 11 & \\
\hline Reading/writing & - -..- & --------- & --------- & 4 & 12 & \\
\hline Alphabet Test & 9 & 41 & ---------- & 20 & 41 & $\begin{array}{l}\text { lmprove, } \\
\text { more } \\
\text { letters } \\
\text { demon- } \\
\text { strated }\end{array}$ \\
\hline Form Test & $\begin{array}{l}\text { Partial } \\
\text { Full } \\
\text { name, } \\
\text { partial } \\
\text { address } \\
\text { missing } \\
\text { the } \\
\text { street, } \\
\text { city and } \\
\text { state }\end{array}$ & Perfect & ---------- & $\begin{array}{l}\text { Worse - } \\
\text { Partial } \\
\text { Handwritin } \\
\mathrm{g} \text { is worse, } \\
\text { address } \\
\text { missing one } \\
\text { number }\end{array}$ & Perfect & Worse \\
\hline
\end{tabular}

COMMENTS ON PARTICULAR TEST QUESTIONS

\begin{tabular}{|c|c|c|}
\hline $\begin{array}{l}\text { Greetings, Personal } \\
\text { Information }\end{array}$ & 1. -5 . Missed one. & 1. -8. Missed one. \\
\hline Describe Common Situation & 6. Home situntion. & $9 .-10$ \\
\hline Time/Numbers & 7. Time: & 11. -13 . Time recognition. \\
\hline & 8. Time get up perfect. & 14. Time get up. \\
\hline Directions, Clarification & $9 .-16$ & $\begin{array}{l}\text { 15. }-23 \text { Cannot give all } \\
\text { directions. }\end{array}$ \\
\hline Money & 11. Does recoginze money. & 24. -26. Does know money. \\
\hline Shopping, Food, Clothing & 10. 12. Can't ask for prices & 27. -28. Can ask for prices. \\
\hline Signs & & 29. -32. Can read 2 of 4 signs \\
\hline $\begin{array}{l}\text { Emergencies, Safety Health, } \\
\text { Body Parts }\end{array}$ & 13. & $33,-41$ \\
\hline Employment, Training & 18. & 42. -45 \\
\hline
\end{tabular}


LONG FORM

Alphabet

Before

Small: abcDeFGHILMNO

Capital: ABDeFHIGMNOb
46-49 Form -4 of 8pts.

\author{
After \\ abcefghlmNopm \\ ABDCeFGHI"J"*KiMNOPQ
}

*the $\mathrm{J}$ is written backwards

Form

\begin{tabular}{|c|c|c|}
\hline Before & After & RESULT \\
\hline 3. First, middle and last name. & 3. First and last name. & - \\
\hline 4. No date of bith. & 4. No date of birth & \\
\hline $\begin{array}{l}\text { 5. Street name- missing city, state } \\
\text { and zip. }\end{array}$ & $\begin{array}{l}\text { 5. Address missing one number, } \\
\text { city, street and zip. }\end{array}$ & - \\
\hline 6. No phone numbel: & 6. No phone number. & \\
\hline 7. No hoilsehold size. & 7. No houschold size. & \\
\hline 8 No information checked off & 8. No information cheeked off. & \\
\hline $\begin{array}{l}\text { 9. No children's names, no ages. } \\
\text { no gender. }\end{array}$ & $\begin{array}{l}\text { 9. No children's names, no ages, no } \\
\text { sex. }\end{array}$ & \\
\hline 10. No signature and no date. & 10. No signature and no date. & \\
\hline
\end{tabular}

\begin{tabular}{|c|c|c|}
\hline Survey One for Somali Women & $\begin{array}{l}\text { Survey Two for Somali } \\
\text { Women }\end{array}$ & Changes \\
\hline A. Print at home none. & A. Print none. & \\
\hline $\begin{array}{l}\text { B. 1. Thinks learning English will be } \\
\text { difficult. }\end{array}$ & $\begin{array}{l}\text { B. 1. Thinks learning English } \\
\text { was not difficult. }\end{array}$ & + \\
\hline 2. Cannot read and write in Somali. & $\begin{array}{l}\text { 2. Camnot read or write in } \\
\text { Somali. }\end{array}$ & \\
\hline 3. Camnot read in English. & $\begin{array}{l}\text { 3. Can read in English - } \\
\text { advanced level. }\end{array}$ & $+*$ \\
\hline 4. Can write the alphabet in English. & $\begin{array}{l}\text { 4. Can write the alphabet in } \\
\text { English. }\end{array}$ & \\
\hline 5. Cannot write sentences in English. & $\begin{array}{l}\text { 5. Cannof write sentences in } \\
\text { English "Learning - not yet." }\end{array}$ & \\
\hline $\begin{array}{l}\text { 6. Cannot speak on the phone in } \\
\text { English. }\end{array}$ & $\begin{array}{l}\text { 6. Cannot speak on the phone } \\
\text { in English }\end{array}$ & \\
\hline $\begin{array}{l}\text { 7. Cannot fill out a job application in } \\
\text { English. }\end{array}$ & $\begin{array}{l}\text { 7. Cannot fill out a job } \\
\text { application in English. }\end{array}$ & \\
\hline $\begin{array}{l}\text { 8. Has family encouragement to learn } \\
\text { English. }\end{array}$ & $\begin{array}{l}\text { 8. Had family encouragement } \\
\text { to learn English. }\end{array}$ & ++ \\
\hline $\begin{array}{l}\text { 9. Plans to spend more than } 1 \text { hour a } \\
\text { day studying. }\end{array}$ & $\begin{array}{l}\text { 9. Spent more than } 1 \text { hour a day } \\
\text { studying. }\end{array}$ & + \\
\hline 10. Looking forward to meeting tutor. & 10. Tutor became a friend. & ++ \\
\hline $\begin{array}{l}\text { 11. Studied English in the US at Steps } \\
\text { for Success for } 8 \text { months }\end{array}$ & 11. Tutor was a good teacher. & ++ \\
\hline $\begin{array}{l}\text { C. Goals are "to be able to read, write } \\
\text { and speak." }\end{array}$ & $\begin{array}{l}\text { 12. Achieved goals. "I learned } \\
\text { to read, speak, write." "I want } \\
\text { to learn English, drive a car and } \\
\text { be able to talk at a } \\
\text { supermarket." "I want more } \\
\text { writing, reading, math and food } \\
\text { names. Good teacher." }\end{array}$ & + \\
\hline
\end{tabular}




\begin{tabular}{|c|c|c|}
\hline Survey One for Tutors & Survey Two for Tutors & Changes \\
\hline $\begin{array}{l}\text { 1. Thinks teaching English will be } \\
\text { difficult. }\end{array}$ & 1. Teaching English was difficult. & \\
\hline $\begin{array}{l}\text { 2. Feels comfortable with people } \\
\text { who do not speak English. }\end{array}$ & $\begin{array}{l}\text { 2. Feels comfortable with people who } \\
\text { do not speak English. }\end{array}$ & \\
\hline $\begin{array}{l}\text { 3. Feels comfortable entering a } \\
\text { Somali household. }\end{array}$ & $\begin{array}{l}\text { 3. Feels comfortable entering a Somali } \\
\text { household. }\end{array}$ & + \\
\hline $\begin{array}{l}\text { 4. Can read or write in another } \\
\text { language - Spanish. }\end{array}$ & $\begin{array}{l}\text { 4. Can read or write in another } \\
\text { language - Spanish. }\end{array}$ & \\
\hline $\begin{array}{l}\text { 5. Hopes to become friends with } \\
\text { student. }\end{array}$ & 5. Became friends with student. & + \\
\hline $\begin{array}{l}\text { 6. Does not plan to spend more } \\
\text { than one hour a day preparing } \\
\text { lessons. }\end{array}$ & $\begin{array}{l}\text { 6. Did spend more than one lour a day } \\
\text { preparing lessons. }\end{array}$ & \\
\hline $\begin{array}{l}\text { 7. Has experience training } \\
\text { someone to fill out a job } \\
\text { application. }\end{array}$ & 7. ESL training was not adequate. & -- \\
\hline $\begin{array}{l}\text { 8. Has } 110 t \text { worked with refugees } \\
\text { before. }\end{array}$ & $\begin{array}{l}\text { 8. Literacy teaching training from LFS } \\
\text { was adequate. "It was a little better } \\
\text { with literacy." }\end{array}$ & +t \\
\hline $\begin{array}{l}\text { 9. Has been to Africa - Zimbabwe } \\
-3 \text { yrs. Foreign service wife, visit } \\
\text { South Africa, Namibia, Botswana } \\
\text { and Swaziland. }\end{array}$ & $\begin{array}{l}\text { 9. Cultural training at LFS was } \\
\text { adequate. "It was wonderful having } \\
\text { Halima and all the reading material. } \\
\text { She was open and talked about } \\
\text { different things." }\end{array}$ & ++ \\
\hline \multirow{7}{*}{$\begin{array}{l}\text { 10. Has ESL tutoring experience. } \\
\text { "Adult literacy through Second } \\
\text { Start Program - Oakland, } \\
\text { California, used Laubach Method." }\end{array}$} & $\begin{array}{l}\text { 10. Received adequate support from } \\
\text { LFS staff. }\end{array}$ & ++ \\
\hline & $\begin{array}{l}\text { 11. Student did do homework outside } \\
\text { of tutoring session. }\end{array}$ & + \\
\hline & $\begin{array}{l}\text { 12. Student did not achieve all of her } \\
\text { goals. "A little - she can read Dr. Seuss } \\
\text { The Foot Book. }\end{array}$ & \\
\hline & $\begin{array}{l}\text { 13. Liked the program's cause. "Why I } \\
\text { personally liked it is that I have an } \\
\text { attachment to Africa. I have done } \\
\text { literacy training." }\end{array}$ & ++ \\
\hline & $\begin{array}{l}\text { 14. Liked the program's content. "If a } \\
\text { person is going to live in this country - } \\
\text { I thought that twice a week, two hours } \\
\text { a setting is all that we could do." }\end{array}$ & ++ \\
\hline & $\begin{array}{l}\text { 15. Does not want to continue as a } \\
\text { tutor in this program. "I would do } \\
\text { literacy tutoring (to native English } \\
\text { speakers) before ESL." }\end{array}$ & - \\
\hline & $\begin{array}{l}\text { 16. Suggestions for other LFS } \\
\text { programs: none Comments: "They're } \\
\text { trapped in their own silence. I'm pretty } \\
\text { exhausted. It was too intense - too time } \\
\text { consuming. I followed the rules. } \\
\text { However, I am continuing to meet with } \\
\text { her on Saturday mornings for } \\
\text { socializing." }\end{array}$ & \\
\hline
\end{tabular}


Identification Name: 250

$2501 / 3$

Tutoring Hours Completed: 14 hours (19\% of 72 hours)

First Test: $\quad 9 / 16 / 99$

Second Test: $\quad 3 / 30 / 00$

\begin{tabular}{|c|c|c|c|c|c|c|}
\hline & $\begin{array}{l}\text { BEST -Short } \\
\text { Form } \\
\text { SCORE }\end{array}$ & $\begin{array}{l}\text { Total Points } \\
\text { Possible }\end{array}$ & $\begin{array}{l}\text { BEST } \\
\text { Short } \\
\text { Form } \\
\text { Adjusted } \\
\text { SCORE }\end{array}$ & $\begin{array}{l}\frac{\text { BEST- }}{\text { Long }} \\
\text { Form } \\
\text { SCORE }\end{array}$ & $\begin{array}{l}\text { Total } \\
\text { Points } \\
\text { Possible }\end{array}$ & Changes \\
\hline Total & 4 & 40 & $8 I I$ & $10 \mathrm{II}$ & 91 & +2 \\
\hline Communication & 0 & 22 & 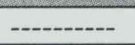 & 6 & 48 & \\
\hline Fluency & 4 & 18 & 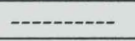 & 2 & 24 & \\
\hline Listening & ---- & --------- & --------- & 2 & 11 & \\
\hline Reading/writing & ---.--- & -------- & -------- & 4 & 12 & \\
\hline Alphabet Test & 0 & 41 & --------- & 2 & 41 & Improve \\
\hline Form Test & Nothing & Perfect & --------- & $\begin{array}{l}\text { First name } \\
\text { only }\end{array}$ & Perfect & Improve \\
\hline
\end{tabular}

\section{COMMENTS ON PARTICULAR TEST QUESTIONS}

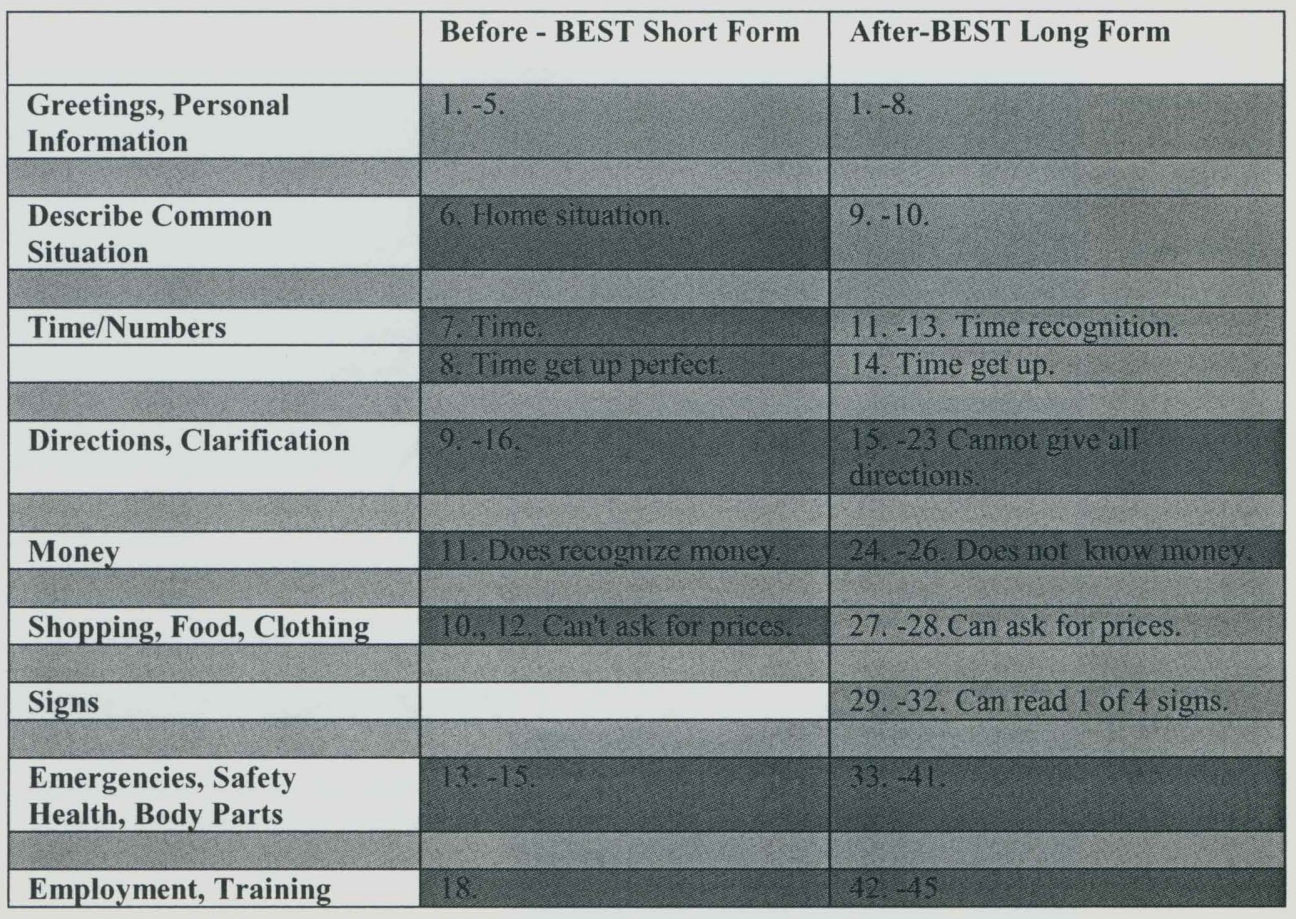


LONG FORM

\section{Alphabet \\ Before \\ Small: ------ \\ Capital: ---}

Form
46-49 Form -1 /8pts. First name only

After

abcd

\begin{tabular}{|c|c|c|}
\hline Before & After & RESULT \\
\hline 3. No nume. & 3. First name only. & + \\
\hline 4. No date of birth. & 4. No date of birth. & \\
\hline 5. No address: & $\begin{array}{l}\text { 5. No address, no zip code, no ciry, no } \\
\text { state. }\end{array}$ & \\
\hline 6. No phone number. & 6. No phone number. & \\
\hline 7. Na household size. & 7. No household size. & \\
\hline 8. No information cliecked-off. & 8. No information checked off. & \\
\hline $\begin{array}{l}\text { 9. No children's names, } n 0 \text { ages, no } \\
\text { gender. }\end{array}$ & 9. No children's names, no ages, no sex. & \\
\hline 10. No signature, no date. & 10. No signature, no date. & \\
\hline
\end{tabular}

\begin{tabular}{|c|c|c|}
\hline Survey One for Somali Women & Survey Two for Somali Women & Changes \\
\hline A. Print at home - none. & A. Print - TV advertisements, food labels. & + \\
\hline $\begin{array}{l}\text { B. 1. Thinks learning English will be } \\
\text { difficult. }\end{array}$ & $\begin{array}{l}\text { B. 1. Thinks learning English was } \\
\text { difficult. }\end{array}$ & \\
\hline 2. Cannot rend and write in Somali. & 2. Cannot read and write in Somall: & \\
\hline $\begin{array}{l}\text { 3. Cannot read in English. } \\
\text { intermediate level. }\end{array}$ & 3. Cannot read in English. & \\
\hline $\begin{array}{l}\text { 4. Cannot write the alphabet in } \\
\text { English. }\end{array}$ & 4. Cannot write the alphabet in English. & \\
\hline $\begin{array}{l}\text { 5. Cannot write sentences in } \\
\text { English. }\end{array}$ & $\begin{array}{l}\text { 5. Cannot wite sentences in English - } \\
\text { basic sentences } 3-5 \text { words. }\end{array}$ & \\
\hline $\begin{array}{l}\text { 6. Cannot speak on the phone in } \\
\text { English. }\end{array}$ & $\begin{array}{l}\text { 6. Can speak on the phone in English. "A } \\
\text { little - hello, fine, hold on, wait." }\end{array}$ & + \\
\hline $\begin{array}{l}\text { 7. Cannot fill out a job application in } \\
\text { English. }\end{array}$ & $\begin{array}{l}\text { 7. Cannot fill out a job application in } \\
\text { English. }\end{array}$ & \\
\hline $\begin{array}{l}\text { 8. Has family encouragement to } \\
\text { learn English. }\end{array}$ & $\begin{array}{l}\text { 8. Had family encouragement to learn } \\
\text { English. }\end{array}$ & ++ \\
\hline $\begin{array}{l}\text { 9. Plans to spend more than } 1 \text { hour a } \\
\text { day studying. }\end{array}$ & $\begin{array}{l}\text { 9. Did spend more than } 1 \text { hour a day } \\
\text { studying. }\end{array}$ & + \\
\hline $\begin{array}{l}\text { 10. Looking forward to meeting } \\
\text { tutor. }\end{array}$ & 10. Tutor became friend. & ++ \\
\hline 11. Did not study English in the US. & 11. Tutor was a good teacher. & ++ \\
\hline $\begin{array}{l}\text { C. Goals are "to be able to } \\
\text { communicate with doctor, and to be } \\
\text { able to understand when teachers } \\
\text { call." }\end{array}$ & $\begin{array}{l}\text { 12. Did not achieve goals. Though } \\
\text { children's interpreting help she sald, "I } \\
\text { like my program but my brain doesn't } \\
\text { work. I want to ty anything but I can't do } \\
\text { it. My brain deesn't work. I am a great- } \\
\text { grandmother. I took one year and I. } \\
\text { learned nothing." }\end{array}$ & - \\
\hline
\end{tabular}




\begin{tabular}{|c|c|c|}
\hline Survey One for Tutors & Survey Two for Tutors & Changes \\
\hline $\begin{array}{l}\text { 1. Thinks teaching English will } \\
\text { be difficult. }\end{array}$ & 1. Teaching English was difficult. & \\
\hline $\begin{array}{l}\text { 2. Feels comfortable with } \\
\text { people who do not speak } \\
\text { English. }\end{array}$ & $\begin{array}{l}\text { 2. Feels comfortable with people } \\
\text { who do not speak English. }\end{array}$ & \\
\hline $\begin{array}{l}\text { 3. Feels comfortable entering a } \\
\text { Somali household. }\end{array}$ & $\begin{array}{l}\text { 3. Feels comfortable entering a } \\
\text { Somali household. }\end{array}$ & \\
\hline $\begin{array}{l}\text { 4. Cannot read or write in } \\
\text { another language. }\end{array}$ & $\begin{array}{l}\text { 4. Cannot read or write in another } \\
\text { language. }\end{array}$ & \\
\hline $\begin{array}{l}\text { 5. Hopes to become friends } \\
\text { with student. }\end{array}$ & 5. Became friends with student. & ++ \\
\hline $\begin{array}{l}\text { 6. Does plan to spend more } \\
\text { than one hour a day preparing } \\
\text { lessons. }\end{array}$ & $\begin{array}{l}\text { 6. Did not spend more than one hour } \\
\text { a day preparmg lessons. }\end{array}$ & + \\
\hline $\begin{array}{l}\text { 7. Has experience training } \\
\text { someone to fill out a job } \\
\text { application. }\end{array}$ & 7. ESI training was not adequate. & -- \\
\hline $\begin{array}{l}\text { 8. Has not worked with } \\
\text { refugees before. }\end{array}$ & $\begin{array}{l}\text { 8. Literacy teaching training from } \\
\text { LFS was not adequate. }\end{array}$ & -- \\
\hline $\begin{array}{l}\text { 9. Has been to Africa - Kenya } \\
\text { and Tanzania, 1997, } 3 \text { weeks as } \\
\text { a tourist. }\end{array}$ & $\begin{array}{l}\text { 9. Cultural training at LFS was } \\
\text { adequate. }\end{array}$ & ++ \\
\hline \multirow[t]{7}{*}{$\begin{array}{l}\text { 10. Has no ESL tutoring } \\
\text { experience. }\end{array}$} & $\begin{array}{l}\text { 10. Received adequate support from } \\
\text { LFS staff. }\end{array}$ & ++ \\
\hline & $\begin{array}{l}\text { 11. Student did not do homework } \\
\text { outside of tutoring session. }\end{array}$ & - \\
\hline & 12. Student did not achieve all of her & - \\
\hline & 13. Liked the program's cause. & + \\
\hline & $\begin{array}{l}\text { 14. Did not like the program's } \\
\text { content. }\end{array}$ & \\
\hline & $\begin{array}{l}\text { 15. Does not want to continue as a } \\
\text { thtor. }\end{array}$ & \\
\hline & $\begin{array}{l}\text { 16. Suggestions for LFS programs: } \\
\text { none. Comments: "My student didn't } \\
\text { know how to hold a pencil. She's } \\
\text { just a delightful woman - highly } \\
\text { interested in America. The reason I } \\
\text { quit is that we would never be } \\
\text { successful in an on-going situation. } \\
\text { She didn't want to study more. It } \\
\text { was too much to overcome." }\end{array}$ & \\
\hline
\end{tabular}


Identification Name: $\mathbf{2 6 0}$

$2601 / 3$

Tutoring Hours Completed: 54 hours (75\% of 72 hours)

First Test: 9/19/99

Second Test: $6 / 30 / 00$

\begin{tabular}{|c|c|c|c|c|c|c|}
\hline & $\frac{\frac{\text { BEST }}{\text { Short }}}{\frac{\text { Form }}{\text { SCORE }}}$ & $\begin{array}{l}\text { Total Points } \\
\text { Possible }\end{array}$ & $\begin{array}{l}\text { BEST } \\
\text { Short } \\
\text { Form } \\
\text { Adjusted } \\
\text { SCORE }\end{array}$ & $\begin{array}{l}\frac{\text { BEST }}{\text { Long }} \\
\frac{\text { Form }}{\text { SCORE }}\end{array}$ & $\begin{array}{l}\text { Total } \\
\text { Points } \\
\text { Possible }\end{array}$ & Changes \\
\hline Total & 26 & 40 & 41 VII & 65 VII & 94 & +24 \\
\hline Communication & 14 & 22 & --------- & 38 & 48 & \\
\hline Fluency & 12 & 18 & --------- & 20 & 24 & \\
\hline Listening & -------- & --------- & --------- & 7 & 11 & \\
\hline Reading/writing & - - - & ---------- & --------- & 7 & 12 & \\
\hline Alphabet Test & 41 & 41 & ----------- & 40 & 41 & $\begin{array}{l}\text { No real } \\
\text { improve- } \\
\text { ment }\end{array}$ \\
\hline Form Test & $\begin{array}{l}\text { Perfect } \\
\text { except no } \\
\text { household } \\
\text { size, no } \\
\text { services } \\
\text { checked, } \\
\text { children's } \\
\text { names but } \\
\text { no sex or } \\
\text { age, full } \\
\text { signature } \\
\text { and date }\end{array}$ & Perfect & ---------- & $\begin{array}{l}\text { Perfect } \\
\text { except no } \\
\text { household } \\
\text { size, } \\
\text { services } \\
\text { were } \\
\text { checked, } \\
\text { children's } \\
\text { names but } \\
\text { no sex or } \\
\text { ages, full } \\
\text { signature } \\
\text { but no } \\
\text { date }\end{array}$ & Perfect & $\begin{array}{l}\text { Date } \\
\text { missing } \\
\text { on the } \\
\text { second } \\
\text { form }\end{array}$ \\
\hline
\end{tabular}

COMMENTS ON PARTICULAR TEST QUESTIONS

\begin{tabular}{|c|c|c|}
\hline & $\begin{array}{l}\text { Before - BEST Short } \\
\text { Form }\end{array}$ & After-BEST Long Form \\
\hline $\begin{array}{l}\text { Greetings, Personal } \\
\text { Information }\end{array}$ & 1. -5 & 1. -8 . \\
\hline Describe Common Situation & 6. Home situation & 9. -10 . \\
\hline Time/Numbers & 7. Time & 11. -13 . Time recognition. \\
\hline & 8. Time get up. & 14. Time get up. \\
\hline Directions, Clarification & 9. -16 & 15. -23 Cannot give all directions. \\
\hline Money & 11. Does recognize money. & 24. -26. Does know money.. \\
\hline Shopping, Food, Clothing & 10., 12. Can't ask for prices. & 27. -28.Can ask for prices. \\
\hline Signs & & 29. -32 . Can read 3 of 4 signs. \\
\hline $\begin{array}{l}\text { Emergencies, Safety Health, } \\
\text { Body Parts }\end{array}$ & 13. -15 & $33,-41$ \\
\hline Employment, Training & 18. & 42. -45 \\
\hline
\end{tabular}




\section{LONG FORM}

\begin{tabular}{|c|c|c|}
\hline $\begin{array}{l}\text { Before } \\
\text { Small: perfect } \\
\text { Capital: perfect } \\
\text { Form }\end{array}$ & $\begin{array}{l}\quad \text { After } \\
\text { perfect } \\
\text { only "i" as a small letter }\end{array}$ & \\
\hline Before & After & RESULT \\
\hline 3. Full name. & 3. Full name. & \\
\hline 4. Date of birth. & 4. No month, no date, only year. & \\
\hline 5. Full address. & 5. Full address. & \\
\hline 6. Full phone number. & 6. Full phone number. & \\
\hline 7. No household size. & 7. No household size: & - \\
\hline 8. No services checked. & 8. No services checked. & - \\
\hline 9. Children's names but no sex or ages. & 9. Children's names but no ages or sex. & \\
\hline 10. Signature and date. & 10. Signature but no date. & - \\
\hline
\end{tabular}

\begin{tabular}{|c|c|c|}
\hline Survey One for Somali Women & Survey Two for Somali Women & Changes \\
\hline A. Print - children's homework. & A. Print - homework, books. & \\
\hline $\begin{array}{l}\text { B. 1. Thinks learning Eaglish will not be } \\
\text { difficult. }\end{array}$ & $\begin{array}{l}\text { B. 1. Thinks learning English was } \\
\text { difficult. }\end{array}$ & - \\
\hline 2. Can read and write in Somali. & 2. Can read and write in Somali. & \\
\hline $\begin{array}{l}\text { 3. Can read in English - intermediate } \\
\text { level. }\end{array}$ & 3. Can read in English - advanced level. & + \\
\hline 4. Can write the alphabet in English. & 4. Can write the alphabet in English. & \\
\hline 5. Can't write sentences in English. & $\begin{array}{l}\text { 5. Cannot write sentences in English - } \\
\text { "can READ sentences." }\end{array}$ & \\
\hline 6. Can speak on the phone in English. & 6. Can speak on the phone in English. & \\
\hline $\begin{array}{l}\text { 7. Camnot fill out a job application in } \\
\text { English "half." }\end{array}$ & $\begin{array}{l}\text { 7. Carnot fill out a job application in } \\
\text { English. }\end{array}$ & - \\
\hline $\begin{array}{l}\text { 8. Has family encouragement to learn } \\
\text { English. }\end{array}$ & $\begin{array}{l}\text { 8. Had family encouragement to learn } \\
\text { English. }\end{array}$ & \\
\hline $\begin{array}{l}\text { 9. Plans to spend more and } 1 \text { hour a day } \\
\text { studying. }\end{array}$ & $\begin{array}{l}\text { 9. Did spend more than } 1 \text { hour a day } \\
\text { studying. }\end{array}$ & \\
\hline 10. Looking forward to meeting tutor. & 10. Tutor became a friend. & \\
\hline 11. Studied English for 3 months at LFS. & 11. Tutor was a good teacher. & \\
\hline $\begin{array}{l}\text { C. Goals are "To be able to communicate } \\
\text { easily like an American." }\end{array}$ & $\begin{array}{l}\text { 12. Did not achieve goals. "I was sick and } \\
\text { the teacher left." "I need more English- } \\
\text { more tutors: Im sick." }\end{array}$ & - \\
\hline
\end{tabular}




\begin{tabular}{|c|c|c|}
\hline Survey One for Tutors & Survey Two for Tutors & Changes \\
\hline $\begin{array}{l}\text { 1. Thinks teaching English will } \\
\text { not bo difficult. }\end{array}$ & 1. Teaching English was not difficult. & + \\
\hline $\begin{array}{l}\text { 2. Feels comfortable with } \\
\text { people who do not speak } \\
\text { English. }\end{array}$ & $\begin{array}{l}\text { 2. Feels comfortable with people who } \\
\text { do not speak English. }\end{array}$ & + \\
\hline $\begin{array}{l}\text { 3. Feels comfortable entering a } \\
\text { Somali household. }\end{array}$ & $\begin{array}{l}\text { 3. Feels comfortable entering a Somali } \\
\text { household. }\end{array}$ & + \\
\hline $\begin{array}{l}\text { 4. Can read or write in another } \\
\text { language. }\end{array}$ & $\begin{array}{l}\text { 4. Can read or write in another } \\
\text { language. }\end{array}$ & \\
\hline $\begin{array}{l}\text { 5. Hopes to become friends } \\
\text { with student. }\end{array}$ & 5. Became friends with student. & + \\
\hline $\begin{array}{l}\text { 6. Does not plan to spend more } \\
\text { than one hour a day preparing } \\
\text { lessons. }\end{array}$ & $\begin{array}{l}\text { 6. Did not spend more than one hour a } \\
\text { day preparing lessons. }\end{array}$ & + \\
\hline $\begin{array}{l}\text { 7. Does not have experience } \\
\text { training someone to fill out a } \\
\text { tob anplication. }\end{array}$ & 7. ESL training at LFS - did not attend. & \\
\hline $\begin{array}{l}8 \text {. Has worked with refugees } \\
\text { before. }\end{array}$ & $\begin{array}{l}\text { 8. Literacy training at LFS did not } \\
\text { attend. }\end{array}$ & \\
\hline $\begin{array}{l}\text { 9. Has been to Africa - Ehtiopia } \\
\text { for } 1 \text { month. }\end{array}$ & $\begin{array}{l}\text { 9. Cultural training at LFS was not } \\
\text { adequate. }\end{array}$ & -- \\
\hline \multirow{7}{*}{$\begin{array}{l}\text { 10. Has ESL tutoring } \\
\text { experience "IRCO Job } \\
\text { Readiness, Peace Corps in } \\
\text { Uzbekistan - ESL secondary } \\
\text { schools and methodologists." }\end{array}$} & $\begin{array}{l}\text { 10. Received adequate support from } \\
\text { LFS staff. }\end{array}$ & ++ \\
\hline & $\begin{array}{l}\text { 11. Student did not study outside of } \\
\text { tutoring session. }\end{array}$ & - \\
\hline & $\begin{array}{l}\text { 12. Student achieved all of her goals. } \\
\text { "At the time - write letters. Half of our } \\
\text { time was writing letters." }\end{array}$ & + \\
\hline & $\begin{array}{l}\text { 13. Liked the program's cause. } \\
\text { "Confidence and support builder for } \\
\text { refugees women. Also made } \\
\text { friendships." }\end{array}$ & + \\
\hline & 14. Liked the program's content. & + \\
\hline & $\begin{array}{l}\text { 15. Does not want to continue as a } \\
\text { tutor. "No time in the future. Seventy- } \\
\text { two hours is a real big commitment." }\end{array}$ & + \\
\hline & $\begin{array}{l}\text { 16. Suggestions for other LFS } \\
\text { programs: none. Comments: "Some of } \\
\text { the women here are more committed } \\
\text { than others." }\end{array}$ & \\
\hline
\end{tabular}


Identification Name: 270

Tutoring Hours Completed: 72 hours (100\% of 72 hours)

$\begin{array}{ll}\text { First Test: } & 9 / 19 / 99 \\ \text { Second Test: } & 7 / 5 / 00\end{array}$

\begin{tabular}{|c|c|c|c|c|c|c|}
\hline & $\begin{array}{l}\frac{\text { BEST - }}{\text { Short }} \\
\text { Form } \\
\text { SCORE }\end{array}$ & $\begin{array}{l}\text { Total } \\
\text { Points } \\
\text { Possible }\end{array}$ & $\begin{array}{l}\text { BEST } \\
\text { Short } \\
\text { Form } \\
\text { Adjusted } \\
\text { SCORE }\end{array}$ & $\begin{array}{l}\text { BEST-Long } \\
\text { Form } \\
\text { SCORE }\end{array}$ & $\begin{array}{l}\text { Total } \\
\text { Points } \\
\text { Possible }\end{array}$ & Changes \\
\hline Total & 8 & 40 & $16 \mathrm{III}$ & 22 III & 91 & +6 \\
\hline Communication & 8 & 22 & 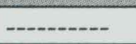 & 18 & 48 & \\
\hline Fluency & 0 & 18 & 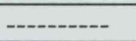 & 2 & 24 & \\
\hline Listening & - & - & 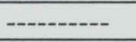 & 2 & 11 & \\
\hline Reading/writing & 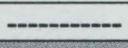 & -------- & --------- & 5 & 8 & \\
\hline Alphabet Test & 15 & 41 & ------ & 27 & 41 & $\begin{array}{l}\text { Improve, } \\
\text { wrote } \\
\text { small } \\
\text { and } \\
\text { capital } \\
\text { letters }\end{array}$ \\
\hline Form Test & Nothing & Perfect & --------- & $\begin{array}{l}\text { Partial-Full } \\
\text { name }\end{array}$ & Perfect & Improve \\
\hline
\end{tabular}

COMMENTS ON PARTICULAR TEST QUESTIONS

\begin{tabular}{|c|c|c|}
\hline & $\begin{array}{l}\text { Before - BEST Short } \\
\text { Form }\end{array}$ & After-BEST Long Form \\
\hline $\begin{array}{l}\text { Greetings, Personal } \\
\text { Information }\end{array}$ & 1. -5. Missed one. & $\begin{array}{l}\text { 1. }-8.8 \text {. Answered in } \\
\text { Somali. }\end{array}$ \\
\hline Describe Common Situation & 6. Home situation. & 9. -10 , \\
\hline Time/Numbers & 7. Time: & 11. -13 . Time recognition. \\
\hline & 8. Time get up perfect. & 14. Time get up. \\
\hline Directions, Clarification & $9 .-16$. & $\begin{array}{l}\text { 15. }-23 \text { Cannot give all } \\
\text { directions. }\end{array}$ \\
\hline Money & 11. Does recognize & 34. -26. Does know money \\
\hline Shopping, Food, Clothing & 10., 12. Can't ask for & 27. -28. Can ask for prices. \\
\hline Signs & & $\begin{array}{l}\text { 29. }-32 \text {. Can read } 2 \text { of } 4 \\
\text { signs. }\end{array}$ \\
\hline $\begin{array}{l}\text { Emergencies, Safety Health, } \\
\text { Body Parts }\end{array}$ & $13 .-15$. & $33 .-41$. \\
\hline Employment, Training & 18. & $\begin{array}{l}\text { 42. }-45 \text { 43. Answered in } \\
\text { Somali. }\end{array}$ \\
\hline
\end{tabular}


LONG FORM

Alphabet

\section{Before}

Small:

Capital:

Form
After

abcDEFJHIGKLmNOpQRStUVWXyZ

46-49 Form - Name 2/2pts.,

Address $1 / 2$ pts.

\section{NOTHING} ABCTEFGHIJKLMNOPQRSDUVWXYZ

\begin{tabular}{|c|c|c|}
\hline Before & After & RESULT \\
\hline 3. No name. & 3. Full name. & + \\
\hline 4. No date of bim. & 4. No date of birth & \\
\hline 5 No aduress: & 5. No address. & \\
\hline 6. No phone number. & 6. No phonc number. & \\
\hline 7. No household size. & 7. No houschold size. & \\
\hline 8. No information checked-off & $\begin{array}{l}\text { 8. No infonnation checked } \\
\text { off. }\end{array}$ & \\
\hline $\begin{array}{l}\text { 9. No children's numes, no ases, no } \\
\text { gender. }\end{array}$ & $\begin{array}{l}\text { 9. No childon's names, no } \\
\text { ages, no gender. }\end{array}$ & \\
\hline 10. No signature, no date. & 10. No signative, no date. & \\
\hline
\end{tabular}

\begin{tabular}{|c|c|c|}
\hline Survey One for Somali Women & Survey Two for Somali Women & Changes \\
\hline B. Print-none. & A. Print-none - lo & \\
\hline $\begin{array}{l}\text { B. 1. Thinks learning F nglish will } \\
\text { be not difficult. }\end{array}$ & $\begin{array}{l}\text { B. 1. Thinks learning English was } \\
\text { difficult. }\end{array}$ & - \\
\hline $\begin{array}{l}\text { 2. Cannot read and write in } \\
\text { Somah. }\end{array}$ & 2. Cannot read and write in Somali. & \\
\hline $\begin{array}{l}\text { 3. Can read in English -beginning } \\
\text { level. }\end{array}$ & 3. Can read in English -intermediate level. & + \\
\hline $\begin{array}{l}\text { 4. Can write the alphabet in } \\
\text { English. }\end{array}$ & 4. Can write the alphabet in English. & \\
\hline $\begin{array}{l}\text { 5. Cannot write sentences in } \\
\text { English. }\end{array}$ & 5. Cannot write sentences in English. & \\
\hline $\begin{array}{l}\text { 6. Cannot speak on the phone in } \\
\text { English. }\end{array}$ & 6. Camnot speak on the phone in English. & \\
\hline $\begin{array}{l}\text { 7. Camnot fill out a job application } \\
\text { in English. }\end{array}$ & $\begin{array}{l}\text { 7. Cannot fill out a job application in } \\
\text { English. }\end{array}$ & \\
\hline $\begin{array}{l}\text { 8. Has family encouragement to } \\
\text { learn English. }\end{array}$ & $\begin{array}{l}\text { 8. Had family encouragement to learn } \\
\text { English. }\end{array}$ & ++ \\
\hline $\begin{array}{l}\text { 9. Plans to spend more than } 1 \text { hour } \\
\text { a day studying. }\end{array}$ & $\begin{array}{l}\text { 9. Did not spend more than } 1 \text { hour a day } \\
\text { studying. }\end{array}$ & - \\
\hline $\begin{array}{l}\text { 10. Looking forward to meeting } \\
\text { tutor. }\end{array}$ & 10. Tutor became a friend. & \\
\hline 11. Studied English at PCC. & 11. Tutor was a good teacher. & \\
\hline $\begin{array}{l}\text { C. Goals are "to be able to shop, } \\
\text { to help my children with } \\
\text { homework and to communicate } \\
\text { with the doctor." }\end{array}$ & $\begin{array}{l}\text { 12. Achieved goals. "Reading and writing - } \\
\text { how to write the alphabet." "I would like to } \\
\text { get a teacher to come two days a week." }\end{array}$ & \\
\hline
\end{tabular}




\begin{tabular}{|c|c|c|}
\hline Survey One for Tutors & Survey Two for Tutors & Changes \\
\hline $\begin{array}{l}\text { 1. Thinks teaching English will be } \\
\text { difficult. }\end{array}$ & 1. Teaching English was difficult. & \\
\hline $\begin{array}{l}\text { 2. Feels comfortable with people who } \\
\text { do not speak English. }\end{array}$ & $\begin{array}{l}\text { 2. Feels comfortable with people } \\
\text { who do not speak English. }\end{array}$ & \\
\hline $\begin{array}{l}\text { 3. Does not feel coinfortable entering a } \\
\text { Somali household. }\end{array}$ & $\begin{array}{l}\text { 3. Feels comfortable entering a } \\
\text { Somali household. }\end{array}$ & ++ \\
\hline $\begin{array}{l}\text { 4. Cannot read or write in another } \\
\text { langthage-"a little Spanish." }\end{array}$ & $\begin{array}{l}\text { 4. Cannot read or write in another } \\
\text { language. }\end{array}$ & \\
\hline $\begin{array}{l}\text { 5. Hopes to become friends with } \\
\text { student. }\end{array}$ & 5. Became friends with student. & \\
\hline $\begin{array}{l}\text { 6. Does not plan to spend more than } \\
\text { one hour a day preparing lessons. }\end{array}$ & $\begin{array}{l}\text { 6. Did not spend more than one hour } \\
\text { a day preparing lessons. }\end{array}$ & \\
\hline $\begin{array}{l}\text { 7. Has experience training someone to } \\
\text { fill out a job application. }\end{array}$ & 15. ESL training - N/A. & \\
\hline $\begin{array}{l}\text { 8. Has not worked with refugees } \\
\text { before. }\end{array}$ & 8. Literacy training - N/A. & \\
\hline 16. Has not been to Africa: & $\begin{array}{l}\text { 9. Cultural training at LFS was } \\
\text { adequate. }\end{array}$ & ++ \\
\hline 10. Has no ESI tutoring experience. & $\begin{array}{l}\text { 10. Received adequate support from } \\
\text { LFS staff. }\end{array}$ & ++ \\
\hline \multirow[t]{6}{*}{$\begin{array}{l}\text { Comments: Excited to be a volunteer } \\
\text { for this project, although it's difficult to } \\
\text { answer some of these questions. } \\
\text { Because I don't know what to expect. } \\
\text { I've never helped anyone learn English } \\
\text { before. }\end{array}$} & $\begin{array}{l}\text { 11. Stident did not do homework } \\
\text { outside of futoring session. "Her kids } \\
\text { would do it for her at the last minute." }\end{array}$ & - \\
\hline & $\begin{array}{l}\text { 12. Student did not achieve all of her } \\
\text { goals. }\end{array}$ & - \\
\hline & $\begin{array}{l}\text { 13. Liked the program's cause. "It's } \\
\text { exciting they created a program to aid } \\
\text { these women in this transition and to } \\
\text { strengthen relationships. We did a lot } \\
\text { of sharing." }\end{array}$ & ++ \\
\hline & 14. Liked the program's content. & \\
\hline & $\begin{array}{l}\text { 15. Does not want to continue as a } \\
\text { lutor. "I'm new to Portland. I would } \\
\text { like work experience with people of } \\
\text { my own age." }\end{array}$ & - \\
\hline & $\begin{array}{l}\text { 16. Suggestions for other LFS } \\
\text { programs - "Help with childcare. She } \\
\text { never left the house. She needs other } \\
\text { people and other activities." }\end{array}$ & \\
\hline
\end{tabular}


Identification Name: $\mathbf{2 8 0}$

Tutoring Hours Completed: 20 hours (28\% of 72 hours)

First Test: $\quad 9 / 20 / 99$

Second Test: $\quad 4 / 27 / 00$

\begin{tabular}{|c|c|c|c|c|c|c|}
\hline & $\begin{array}{l}\text { BEST - } \\
\text { Short Form } \\
\text { SCORE }\end{array}$ & $\begin{array}{l}\text { Total } \\
\text { Points } \\
\text { Possible }\end{array}$ & $\begin{array}{l}\text { BEST } \\
\text { Short } \\
\text { Form } \\
\text { Adjusted } \\
\text { SCORE }\end{array}$ & $\frac{\frac{\text { BEST }}{\text { Long }}}{\frac{\text { Form }}{\text { SCORE }}}$ & $\begin{array}{l}\text { Total } \\
\text { Points } \\
\text { Possible }\end{array}$ & Changes \\
\hline Total & 31 & 38 & $6 I V I I$ & $68 \mathrm{VII}$ & 91 & +7 \\
\hline Communication & 18 & 20 & --.----- & 38 & 48 & \\
\hline Fluency & 13 & 18 & --------- & 21 & 24 & \\
\hline Listening & - ------- & 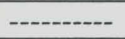 & --------- & 9 & 11 & \\
\hline Reading/writing & ------- & ---------- & ---------- & 4 & 8 & \\
\hline Alphabet Test & 1 & 41 & ---------- & 10 & 41 & $\begin{array}{l}\text { Improve, } \\
\text { write } \\
\text { small and } \\
\text { capital } \\
\text { letters }\end{array}$ \\
\hline Form Test & $\begin{array}{l}\text { Children's } \\
\text { names only, } \\
\text { *Can read } \\
\text { the } \\
\text { instructions }\end{array}$ & Perfect & --------- & $\begin{array}{l}\text { Partial- } \\
\text { Full } \\
\text { name, } \\
\text { children } \\
\text { 's } \\
\text { names, } \\
\text { and } \\
\text { street } \\
\text { address }\end{array}$ & Perfect & Improve \\
\hline
\end{tabular}

COMMENTS ON PARTICULAR TEST QUESTIONS

\begin{tabular}{|c|c|c|}
\hline & $\begin{array}{l}\text { Before - BEST Short } \\
\text { Form }\end{array}$ & After-BEST Long Form \\
\hline $\begin{array}{l}\text { Greetings, Personal } \\
\text { Information }\end{array}$ & $1 .-5$ & $1 .-8$. \\
\hline $\begin{array}{l}\text { Describe Common } \\
\text { Situation }\end{array}$ & 6. Home situation. & 9. -10 . \\
\hline Time/Numbers & 7. Time. & 11. -13 . Time recognition. \\
\hline & 8. Time get up perfect. & 14. Time get up. \\
\hline Directions, Clarification & 9. -16 . & 15. -23 \\
\hline Money & $\begin{array}{l}\text { 11. Does recognize } \\
\text { money. }\end{array}$ & 24. -26. Does know money. \\
\hline Shopping, Food, Clothing & 10., 12. Can ask for prices. & 27. -28.Can ask for prices. \\
\hline Signs & & $\begin{array}{l}\text { 29. }-32 \text {. Can read } 4 \text { of } 4 \\
\text { signs. }\end{array}$ \\
\hline $\begin{array}{l}\text { Emergencies, Safety } \\
\text { Health, Body Parts }\end{array}$ & $13 .-15$ & 33. -41 . \\
\hline Employment, Training & 18. & 42. -45 . \\
\hline
\end{tabular}


LONG FORM

\section{Alphabet}

\section{Before}

Small:

Capital:

Form

\begin{tabular}{|l|l|l|}
\hline Before & After & RESULT \\
\hline 3. Full name. & 3. Full name. & \\
\hline 4. Date of Birth. & 4. Date of Birth. & \\
\hline 5. Perfect address. & 5. Perfect address. & \\
\hline 6. Phone number. & 6. Phone number. & \\
\hline 7. No houschold size. & 7. Household size. & + \\
\hline 8. Information checked-off. & 8. Information checked-off. & \\
\hline 9. Children's names, ages, sex. & 9. Children's names, no ages, no sex. & - \\
& & \\
\hline 10. Signature, date. & 10. Signature, date. & \\
\hline
\end{tabular}

\begin{tabular}{|c|c|c|}
\hline Survey One for Somali Women & Survey Two for Somali Women & Changes \\
\hline $\begin{array}{l}\text { A. Print at home - bills, children's } \\
\text { homework. }\end{array}$ & $\begin{array}{l}\text { A. Print - food packages, sometimes } \\
\text { newspapers. }\end{array}$ & \\
\hline $\begin{array}{l}\text { B. 1. Thinks learning English will be } \\
\text { not difficult. }\end{array}$ & $\begin{array}{l}\text { B. 1. Thinks learning English was not } \\
\text { difficult. "Really is OK. Writing and } \\
\text { spelling are hard. Sometimes I spell } \\
\text { wrong." }\end{array}$ & \\
\hline 2. Can read and write in Somali. & 2. Can read and write in Somali. & \\
\hline $\begin{array}{l}\text { 3. Can read in English -advanced } \\
\text { level. }\end{array}$ & $\begin{array}{l}\text { 3. Can read in English -advanced } \\
\text { level. }\end{array}$ & + \\
\hline 4. Can write the alphabet in English. & 4. Can write the alphabet in English. & \\
\hline $\begin{array}{l}\text { 5. Can write sentences in English, } \\
\text { more than } 5 \text { words. }\end{array}$ & $\begin{array}{l}\text { 5. Can write sentences in English- } \\
\text { long - more than } 5 \text { words. }\end{array}$ & + \\
\hline 6. Can speak on the phone in English. & 6. Can speak on the phone in English. & \\
\hline $\begin{array}{l}\text { 7. Can fill out a job application in } \\
\text { English. }\end{array}$ & $\begin{array}{l}\text { 7. Can fill out a job application in } \\
\text { English. }\end{array}$ & \\
\hline $\begin{array}{l}\text { 8. Has family encouragement to learn } \\
\text { English }\end{array}$ & $\begin{array}{l}\text { 8. Had family encouragement to learn } \\
\text { English. }\end{array}$ & \\
\hline $\begin{array}{l}\text { 9. Plans to spend more than } 1 \text { hour a } \\
\text { day studying. }\end{array}$ & $\begin{array}{l}\text { 9. Spent more than } 1 \text { hour a day } \\
\text { studying. }\end{array}$ & \\
\hline 10. Looking forward to meeting tutor. & 10. Tutor became a friend. & \\
\hline $\begin{array}{l}\text { 11. Studied English for } 2 \text { months at } \\
\text { IRCO. }\end{array}$ & 11. Tutor was a good teacher. & \\
\hline $\begin{array}{l}\text { C. Goals are "to be able to go to } \\
\text { college." }\end{array}$ & $\begin{array}{l}\text { 12. Achieved goals. "I learned what I } \\
\text { wanted. Lutheran Family Service } \\
\text { should help people learn how to } \\
\text { drive, study English and help with } \\
\text { learning computers. Here (the US) is } \\
\text { good but..." }\end{array}$ & \\
\hline
\end{tabular}

" $a b$ "cdeefgHouqrwz

After

46-49 Form -8 of 8 pts. Perfect

\section{ALL PERFECT}

\section{ALL PERFECT}




\begin{tabular}{|c|c|c|}
\hline Survey One for Tutors & Survey Two for Tutors & Changes \\
\hline $\begin{array}{l}\text { 1. Thinks teaching English will be } \\
\text { difficult }\end{array}$ & 1. Teaching English was difficult & \\
\hline $\begin{array}{l}\text { 2. Feels comfortable with people who do } \\
\text { not speak English }\end{array}$ & $\begin{array}{l}\text { 2. Feels comfortable with people } \\
\text { who do not speak English }\end{array}$ & \\
\hline $\begin{array}{l}\text { 3. Does not feel comfortable entering a } \\
\text { Sonali household }\end{array}$ & $\begin{array}{l}\text { 3. Feels comfortable entering a } \\
\text { Somali household }\end{array}$ & + \\
\hline 4. Can read or write in another language & $\begin{array}{l}\text { 4. Can read or write in another } \\
\text { language }\end{array}$ & \\
\hline 5. Hopes to become friends with student & 5. Became friends with student & + \\
\hline $\begin{array}{l}\text { 6. Does not plans to spend more than one } \\
\text { hour a day preparing lessons }\end{array}$ & $\begin{array}{l}\text { 6. Did not speid more than one } \\
\text { hour a day preparing lessons }\end{array}$ & \\
\hline $\begin{array}{l}\text { 7. Has experience training someone to fill } \\
\text { out a job application }\end{array}$ & 7. ESL training was adequate & \\
\hline 8. Has not worked with refugees before & $\begin{array}{l}\text { 8. Literacy teaching training from } \\
\text { LFS was adequate }\end{array}$ & \\
\hline 9. Has not been to Afriea & $\begin{array}{l}\text { 9. Cultural training at LFS was } \\
\text { adequate. }\end{array}$ & \\
\hline \multirow{7}{*}{$\begin{array}{l}\text { 10. Has ESL tutoring experience - } \\
\text { "Tutored Hispanic children and adults } \\
\text { when I was in college." }\end{array}$} & $\begin{array}{l}\text { 10. Received adequate support } \\
\text { from LFS staff. }\end{array}$ & \\
\hline & $\begin{array}{l}\text { 11. Student did do homework } \\
\text { outside of tutoring session. }\end{array}$ & + \\
\hline & 12. Student did achieve her goals. & + \\
\hline & 13. Liked the program's cause. & ++ \\
\hline & 14. Liked the program's content. & ++ \\
\hline & $\begin{array}{l}\text { 15. Does not want to continue as a } \\
\text { tutor. }\end{array}$ & - \\
\hline & $\begin{array}{l}\text { 16. No suggestions for other LFS } \\
\text { programs - }\end{array}$ & \\
\hline
\end{tabular}


Identification Name: 290

Tutoring Hours Completed: 72 hours (100\% of 72 hours)

First Test: $\quad 10 / 5 / 99$

Second Test: $\quad 8 / 7 / 00$

\begin{tabular}{|c|c|c|c|c|c|c|}
\hline & 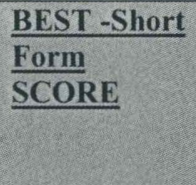 & $\begin{array}{l}\text { Total } \\
\text { Points } \\
\text { Possible }\end{array}$ & $\begin{array}{l}\text { BEST } \\
\text { Short } \\
\text { Form } \\
\text { Adjusted } \\
\text { SCORE }\end{array}$ & $\begin{array}{l}\text { BEST- } \\
\text { Long } \\
\text { Form } \\
\text { SCORE }\end{array}$ & $\begin{array}{l}\text { Total } \\
\text { Points } \\
\text { Possible }\end{array}$ & Changes \\
\hline Total & 6 & 40 & $13 \mathrm{II}$ & $\begin{array}{l}31 \\
\text { VI }\end{array}$ & 91 & +18 \\
\hline Communication & 6 & 22 & ------- & 17 & 48 & \\
\hline Fluency & 0 & 18 & --------- & 6 & 24 & \\
\hline Listening & - ---- & --------- & --------- & 2 & 11 & \\
\hline Reading/writing & - - - & ------- & -------- & 4 & 12 & \\
\hline Alphabet Test & 1 & 41 & 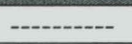 & 10 & 41 & Improve \\
\hline Form Test & $\begin{array}{l}\text { Children's } \\
\text { names only } \\
\text { *Can read } \\
\text { the } \\
\text { instructions }\end{array}$ & Perfect & ---------- & $\begin{array}{l}\text { Partial - } \\
\text { Full name, } \\
\text { children's } \\
\text { names and } \\
\text { street } \\
\text { address }\end{array}$ & Perfect & Improve \\
\hline
\end{tabular}

COMMENTS ON PARTICULAR TEST QUESTIONS

\begin{tabular}{|c|c|c|}
\hline & $\begin{array}{l}\text { Before - BEST Short } \\
\text { Form }\end{array}$ & After-BEST Long Form \\
\hline $\begin{array}{l}\text { Greetings, Personal } \\
\text { Information }\end{array}$ & 1. - 5. Missed two. & 1. -8 . \\
\hline Describe Common Situation & 6. Home situation. & 9. -10 . \\
\hline Time/Numbers & 7. Time. & 11. -13 . Time recognition. \\
\hline & 8. Time get up perfect. & 14. Time get up. \\
\hline Directions, Clarification & 9. -16 . & $\begin{array}{l}15 .-23 \text { Cannot give all } \\
\text { directions. }\end{array}$ \\
\hline Money & $\begin{array}{l}\text { 11. Does recognize } \\
\text { money. }\end{array}$ & $\begin{array}{l}\text { 24. }-26 \text {. Does not know } \\
\text { money well. }\end{array}$ \\
\hline Shopping, Food, Clothing & $\begin{array}{l}10.12 . \text { Can't ask for } \\
\text { prices. }\end{array}$ & $27 .-28$ \\
\hline Signs & & 29. -32. Can read 1 of 4 signs. \\
\hline $\begin{array}{l}\text { Emergencies, Safety Health, } \\
\text { Body Parts }\end{array}$ & $13 .-15$ & $33 .-41$ \\
\hline Employment, Training & 18. & 42. -45 Only one right. \\
\hline
\end{tabular}


LONG FORM

46-49 Form -7 of 8pts. Address is missing the city, state and zip

Alphabet

\section{Before}

Small: $a b C$

Capital: -.-

\section{After}

copied letters $\mathrm{a}, \mathrm{b}, \mathrm{m}, \mathrm{t}$

copied letters A, G,M,P,Y

Form

\begin{tabular}{|l|l|l|}
\hline Before & After & RESULT \\
\hline 3. No name: & $\begin{array}{l}\text { 3. Full name. } \\
\text { 4. No date of birth. }\end{array}$ & + \\
\hline 5. No address. No date of birth. & $\begin{array}{l}\text { 5. +street address, no zip code, no } \\
\text { city, no state. }\end{array}$ & + \\
\hline 6. No phone number. & 6. No phone number: & \\
\hline 7. No household size. & 7. No household size. & \\
\hline 8. No informaiton cliecked-otf. & $\begin{array}{l}\text { 8. Children's names, no ages, no } \\
\text { sex. }\end{array}$ & \\
\hline $\begin{array}{l}\text { 9. Children's names only no } \\
\text { ages, no gender. }\end{array}$ & A. No signature, no date. & \\
\hline 10. No signature, no date. & \\
\hline
\end{tabular}

\begin{tabular}{|c|c|c|}
\hline Survey One for Somali Women & $\begin{array}{l}\text { Survey Two for Somali } \\
\text { Women }\end{array}$ & Changes \\
\hline A. Print at home -none. & A. Print -none. & \\
\hline $\begin{array}{l}\text { B. 1. Thinks learning English will } \\
\text { be difficult. }\end{array}$ & $\begin{array}{l}\text { B. 1. Thinks learning English } \\
\text { was difficult. }\end{array}$ & \\
\hline 2. Can read and write in Somali. & 2. Can read and write in Somali. & \\
\hline 3. Cannot read in English. & $\begin{array}{l}\text { 3. Can read in English - } \\
\text { intermediate level. }\end{array}$ & + \\
\hline $\begin{array}{l}\text { 4. Can write the alphabet in } \\
\text { English. }\end{array}$ & $\begin{array}{l}\text { 4. Can write the alphabet in } \\
\text { English. }\end{array}$ & \\
\hline $\begin{array}{l}\text { 5. Camnot write sentences in } \\
\text { English. }\end{array}$ & $\begin{array}{l}\text { 5. Can write sentences in } \\
\text { English - basic sentences } 3-5 \\
\text { words. }\end{array}$ & + \\
\hline $\begin{array}{l}\text { 6. Cannot speak on the phone in } \\
\text { English. }\end{array}$ & $\begin{array}{l}\text { 6. Cannot speak oil the phone in } \\
\text { English. }\end{array}$ & \\
\hline $\begin{array}{l}\text { 7. Cannot fill out a job application } \\
\text { in English. }\end{array}$ & $\begin{array}{l}\text { 7. Cammot fill out a job } \\
\text { application in English. }\end{array}$ & \\
\hline $\begin{array}{l}\text { 8. Has family encouragement to } \\
\text { learn English. }\end{array}$ & $\begin{array}{l}\text { 8. Had family encouragement to } \\
\text { learn English. }\end{array}$ & \\
\hline $\begin{array}{l}\text { 9. Plans to spend more than } 1 \text { hour } \\
\text { a day studying. }\end{array}$ & $\begin{array}{l}\text { 9. Did not spend more thanl } \\
\text { hour a day studying }\end{array}$ & - \\
\hline $\begin{array}{l}\text { 10. Looking forward to meeting } \\
\text { tutor. }\end{array}$ & $\begin{array}{l}\text { 10. Tutor - friend. REFUSED } \\
\text { TO ANSWER. }\end{array}$ & \\
\hline 11. Studied English in the US. & $\begin{array}{l}\text { 11. Tutor - good teacher. } \\
\text { REFUSED TO ANSWER. }\end{array}$ & \\
\hline $\begin{array}{l}\text { C. Goals are "to be able to talk } \\
\text { fluently, communicate with doctor, } \\
\text { to talk with teachers, shop, and to } \\
\text { get a better job." }\end{array}$ & $\begin{array}{l}\text { 12. Achieved goals. REFUSED } \\
\text { TO ANSWER. }\end{array}$ & \\
\hline
\end{tabular}




\begin{tabular}{|c|c|c|}
\hline Survey One for Tutors & Survey Two for Tutors & Changes \\
\hline $\begin{array}{l}\text { 1. Thinks teaching English will be } \\
\text { difficult. }\end{array}$ & 1. Teaching English was difficult. & \\
\hline $\begin{array}{l}\text { 2. Feels comfortable with people } \\
\text { who do not speak English. }\end{array}$ & $\begin{array}{l}\text { 2. Feels comfortable with people who do } \\
\text { not speak English. }\end{array}$ & \\
\hline $\begin{array}{l}\text { 3. Feels comfortable entering a } \\
\text { Somali household. }\end{array}$ & $\begin{array}{l}\text { 3. Feels comfortable entering a Somali } \\
\text { household. }\end{array}$ & \\
\hline $\begin{array}{l}\text { 4. Cannot read or write in another } \\
\text { langutage. }\end{array}$ & 4. Cannot read or write in another language. & \\
\hline $\begin{array}{l}\text { 5. Hopes to become friends with } \\
\text { student. }\end{array}$ & 5. Became friends with student. & + \\
\hline $\begin{array}{l}\text { 6. Does not plan to spend more than } \\
\text { one hour a day preparing lessons. }\end{array}$ & $\begin{array}{l}\text { 6. Did not spend more than one hour a day } \\
\text { preparing lessons. }\end{array}$ & \\
\hline $\begin{array}{l}\text { 7. Did not have experience training } \\
\text { someone to fill out a job application. }\end{array}$ & 7. ESL training was adequate. & ++ \\
\hline 8. Has worked with refugees before. & $\begin{array}{l}\text { 8. Literacy teaching training from LFS was } \\
\text { adequate. }\end{array}$ & ++ \\
\hline 9. Has not been to Africa. & $\begin{array}{l}\text { 9. Cultural training at LFS was adequate. "It } \\
\text { was great to get Islam on the table with the } \\
\text { Americans' opinions." }\end{array}$ & ++ \\
\hline \multirow[t]{7}{*}{ 10. Has no ESI, futoring experience. } & $\begin{array}{l}\text { 10. Received adequate support from LFS } \\
\text { staff. }\end{array}$ & ++ \\
\hline & $\begin{array}{l}\text { 11. Student did homework outside of } \\
\text { tutoring session. }\end{array}$ & ++ \\
\hline & 12. Student did not achieve her goals. & \\
\hline & $\begin{array}{l}\text { 13. Liked the program's cause. "I think that } \\
\text { there was a need - surfaced from the } \\
\text { community. The Benadir community was } \\
\text { behind." }\end{array}$ & ++ \\
\hline & 14. Liked the program's content. & ++ \\
\hline & 15. Does not want to continue as a tutor. & - \\
\hline & $\begin{array}{l}\text { 16. Suggestions for LFS programs and } \\
\text { comments: "I think that there was a need. It } \\
\text { surfaced from the community. The Benadir } \\
\text { community was left behind. She practiced } \\
\text { handwriting." }\end{array}$ & \\
\hline
\end{tabular}


Identification Name: $\mathbf{3 0 0}$

$300 \quad 1 / 3$

Tutoring Hours Completed: 21 hours (29\% of 72 hours)

First Test: $9 / 8 / 99$

Second Test: $3 / 30 / 00$

\begin{tabular}{|c|c|c|c|c|c|c|}
\hline & $\frac{\frac{\text { BEST }}{\text { Short Form }}}{\text { SCORE }}$ & $\begin{array}{l}\text { Total } \\
\text { Points } \\
\text { Possible }\end{array}$ & $\begin{array}{l}\text { BEST } \\
\text { Short } \\
\text { Form } \\
\text { Adjusted } \\
\text { SCORE }\end{array}$ & $\frac{\text { BEST- Long }}{\text { Form SCORE }}$ & $\begin{array}{l}\text { Total } \\
\text { Points } \\
\text { Possible }\end{array}$ & Changes \\
\hline Total & 18 & 40 & $36 \mathrm{VII}$ & $49 \mathrm{VII}$ & 94 & +13 \\
\hline $\begin{array}{l}\text { Communica } \\
\text { tion }\end{array}$ & 12 & 22 & ---------- & 30 & 48 & \\
\hline Fluency & 6 & 18 & ----o---- & 10 & 24 & \\
\hline Listening & ------ & --------- & -------- & 9 & 11 & \\
\hline $\begin{array}{l}\text { Reading/wri } \\
\text { ting }\end{array}$ & - --- & --------- & ---------- & 3 & 12 & \\
\hline $\begin{array}{l}\text { Alphabet } \\
\text { Test }\end{array}$ & 5 & 41 & ---------- & 4 & 41 & Worse \\
\hline Form Test & Nothing & Perfect & --------- & $\begin{array}{l}\text { Full name } \\
\text { only }\end{array}$ & Perfect & $\begin{array}{l}\text { Small } \\
\text { improve } \\
\text { ment }\end{array}$ \\
\hline
\end{tabular}

COMMENTS ON PARTICULAR TEST QUESTIONS

\begin{tabular}{|c|c|c|}
\hline & $\begin{array}{l}\text { Before - BEST Short } \\
\text { Form }\end{array}$ & After-BEST Long Form \\
\hline Greetings, Personal Information & 1. -5 & 1. -8 . \\
\hline Describe Common Situation & 6. Home situation. & 9. -10 . \\
\hline Time/Numbers & 7. Time. & $\begin{array}{l}\text { 11. }-13 \text {. Time } \\
\text { recognition. }\end{array}$ \\
\hline & 8. Time get up perfect. & 14. Time get up. \\
\hline Directions, Clarification & 9. -16 & $15 .-23$ \\
\hline Money & 11. Does recognize money. & $\begin{array}{l}\text { 24. }-26 \text {. Does know } \\
\text { money. }\end{array}$ \\
\hline Shopping, Food, Clothing & 10., 12. Can ask for prices. & 27. -28 \\
\hline Signs & & 29. -32. Camnot read 4 \\
\hline $\begin{array}{l}\text { Emergencies, Safety Health, } \\
\text { Body Parts }\end{array}$ & 13. -15 & $33,-41$ \\
\hline Employment, Training & & $42 .-45$ \\
\hline
\end{tabular}

LONG FORM

46. Name $2 / 2$ pts.

47. No address.

48. No signature.

49. Date $1 / 2$ pts. -spelled "MAH 30." 


\begin{tabular}{|c|c|c|}
\hline $\begin{array}{l}\text { Before } \\
\text { Small: } \\
\text { Capital: ABCDGFEGHMPIJKLMNYO } \\
\text { PQRST } \\
\text { Form } \\
\end{array}$ & $\begin{array}{c}\text { After } \\
\text { aBc "mpty" all copied. }\end{array}$ & \\
\hline Before & After & RESULT \\
\hline 3. No full name. & 3. Full name. & + \\
\hline 4. No date of bith. & 4. No date of birth. & \\
\hline 5. No address. & 5. No full address. & \\
\hline 6. No phone number. & 6. No full phone number & \\
\hline 7. No hoisseholt size. & 7. No houschold size. & \\
\hline 8. No sernices checked. & 8. No services checked. & \\
\hline $\begin{array}{l}\text { 9. No children's names, no sex, no } \\
\text { ages. }\end{array}$ & $\begin{array}{l}\text { 9. No children's names, no } \\
\text { ages, no sex. }\end{array}$ & \\
\hline 10. No signature and no date. & 10. No signatire, no ditte. & \\
\hline
\end{tabular}

\begin{tabular}{|c|c|c|}
\hline Survey One for Somali Women & Survey Two for Somali Women & Changes \\
\hline A. Print - children's homework. & A. Print - homework, books. & \\
\hline $\begin{array}{l}\text { B. } 1 \text { Thinks learning English will not } \\
\text { be difficult. }\end{array}$ & $\begin{array}{l}\text { B. 1. Thinks learning English was } \\
\text { difficult. }\end{array}$ & - \\
\hline 2. Can read and write in Somali. & 2. Can read and write in Somali. & \\
\hline $\begin{array}{l}\text { 3. Can read in English - intermediate } \\
\text { level. }\end{array}$ & $\begin{array}{l}\text { 3. Can read in English - advanced } \\
\text { level. }\end{array}$ & + \\
\hline 4. Can write the alphabet in English. & $\begin{array}{l}\text { 4. Can write the alphabet in } \\
\text { English. }\end{array}$ & \\
\hline 5. Cailt write sentences in English. & $\begin{array}{l}\text { 5. Camnot write sentences in } \\
\text { English - "can READ sentences" }\end{array}$ & * \\
\hline 6. Can speak on the phone in English. & $\begin{array}{l}\text { 6. Can speak on the phone in } \\
\text { English. }\end{array}$ & \\
\hline $\begin{array}{l}\text { 7. Cannot fill out a job application in } \\
\text { English "thalf." }\end{array}$ & $\begin{array}{l}\text { 7. Cannot fill out a job application } \\
\text { in Enulish. }\end{array}$ & - \\
\hline $\begin{array}{l}\text { 8. Has family encouragement to learn } \\
\text { English. }\end{array}$ & $\begin{array}{l}\text { 8. Had family encouragement to } \\
\text { learn English. }\end{array}$ & \\
\hline $\begin{array}{l}\text { 9. Plans to spend more than } 1 \text { hour a day } \\
\text { studying. }\end{array}$ & $\begin{array}{l}\text { 9. Did spend more than } 1 \text { hour a } \\
\text { day studying. }\end{array}$ & ++ \\
\hline 10. Looking forward to meeting tutor. & 10. Tutor became a friend. & + \\
\hline $\begin{array}{l}\text { 11. Studied English for } 3 \text { months at } \\
\text { LFS. }\end{array}$ & 11. Tutor was a good teacher. & ++ \\
\hline $\begin{array}{l}\text { C. Goals are "To be able to } \\
\text { communicate easily like an American." }\end{array}$ & 12. Did not achieve goals. & \\
\hline
\end{tabular}




\begin{tabular}{|c|c|c|}
\hline Survey One for Tutors & Survey Two for Tutors & Changes \\
\hline $\begin{array}{l}\text { 1. Thinks teaching English } \\
\text { will not be difficult. }\end{array}$ & $\begin{array}{l}\text { 1. Teaching English was not } \\
\text { difficult }\end{array}$ & + \\
\hline $\begin{array}{l}\text { 2. Feels comfortable with } \\
\text { people who do not speak } \\
\text { English. }\end{array}$ & $\begin{array}{l}\text { 2. Feels comfortable with people } \\
\text { who do not speak English. }\end{array}$ & + \\
\hline $\begin{array}{l}\text { 3. Feels comfortable entering } \\
\text { a Somali household. }\end{array}$ & $\begin{array}{l}\text { 3. Feels comfortable entering a } \\
\text { Somali household. }\end{array}$ & \\
\hline $\begin{array}{l}\text { 4. Can read or write in } \\
\text { another language. }\end{array}$ & $\begin{array}{l}\text { 4. Can read or write in another } \\
\text { language. }\end{array}$ & \\
\hline $\begin{array}{l}\text { 5. Hopes to become friends } \\
\text { with student. }\end{array}$ & 5. Became friends with student. & + \\
\hline $\begin{array}{l}\text { 6. Does not plan to spend } \\
\text { more than one hour a day } \\
\text { preparing lessons. }\end{array}$ & $\begin{array}{l}\text { 6. Did not spend more than one } \\
\text { hour a day preparing lessons. }\end{array}$ & \\
\hline $\begin{array}{l}\text { 7. Does not have experience } \\
\text { training someone to fill out a } \\
\text { job application. }\end{array}$ & $\begin{array}{l}\text { 16. ESL training at LFS -did not } \\
\text { attend. }\end{array}$ & - \\
\hline $\begin{array}{l}\text { 8. Has worked with refugees } \\
\text { before. }\end{array}$ & $\begin{array}{l}\text { 8. Literacy training at LFS did } \\
\text { not attend. }\end{array}$ & - \\
\hline $\begin{array}{l}\text { 17. Has been to Africa - } \\
\text { Ethiopia for } 1 \text { month. }\end{array}$ & $\begin{array}{l}\text { 9. Cultural training at LFS was } \\
\text { not adequate. }\end{array}$ & - \\
\hline \multirow{7}{*}{$\begin{array}{l}\text { 10. Has ESL tutoring } \\
\text { experience "IRCO Job } \\
\text { Readiness, Peace Corps in } \\
\text { Uzbekistan - ESL secondary } \\
\text { schools and methodologists." }\end{array}$} & $\begin{array}{l}\text { 10. Received adequate support } \\
\text { from LFS staff. }\end{array}$ & \\
\hline & 11. Student did not study outside & - \\
\hline & $\begin{array}{l}\text { 12. Student achieved all of her } \\
\text { goals. "At the time - write letters. } \\
\text { Half of our time was writing } \\
\text { letters." }\end{array}$ & + \\
\hline & $\begin{array}{l}\text { 13. Liked the program's cause. } \\
\text { "Confidence and support builder } \\
\text { for refugees women. Also made } \\
\text { friendships." }\end{array}$ & + \\
\hline & 14. Liked the program's content. & + \\
\hline & $\begin{array}{l}\text { 15. Does not want to continue as } \\
\text { a tutor. "No time in the future. } \\
\text { Seventy-two hours is a real big } \\
\text { commitment." }\end{array}$ & + \\
\hline & $\begin{array}{l}\text { 16. Suggestions for other LFS } \\
\text { programs: none. Comments: } \\
\text { "Some of the women here are } \\
\text { more committed than others." }\end{array}$ & \\
\hline
\end{tabular}


Identification Name: 320

Tutoring Hours Completed: 36 hours (50\% of 72 hours)

First Test: $\quad 10 / 5 / 99$

Second Test: $\quad 8 / 9 / 00$

\begin{tabular}{|c|c|c|c|c|c|c|}
\hline & $\begin{array}{l}\frac{\text { BEST - }}{\text { Short }} \\
\text { Form } \\
\text { SCORE }\end{array}$ & $\begin{array}{l}\text { Total } \\
\text { Points } \\
\text { Possible }\end{array}$ & $\begin{array}{l}\text { BEST } \\
\text { Short } \\
\text { Form } \\
\text { Adjusted } \\
\text { SCORE }\end{array}$ & $\frac{\frac{\text { BEST- }}{\text { Long Form }}}{\text { SCORE }}$ & $\begin{array}{l}\text { Total } \\
\text { Points } \\
\text { Possible }\end{array}$ & Changes \\
\hline Total & 13 & 38 & 26 & 22 & 91 & $\begin{array}{l}\text { Worse. } \\
-4\end{array}$ \\
\hline Communication & 9 & 20 & - - & 16 & 48 & \\
\hline Fluency & 4 & 18 & - - & 2 & 24 & \\
\hline Listening & $-\ldots$ & - - & 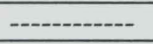 & 4 & 11 & \\
\hline Reading/writing & - - & - & 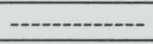 & 0 & 8 & \\
\hline Alphabet Test & 5 & 41 & ----------- & 0 & 41 & Worse, -5 \\
\hline Form Test & None & Perfect & ------------ & $\begin{array}{l}\text { Partial- } \\
\text { name, street } \\
\text { address and } \\
\text { zip }\end{array}$ & Perfect & $\begin{array}{l}\text { Improve.F } \\
\text { ull name } \\
\text { and } \\
\text { address } \\
\text { without } \\
\text { city }\end{array}$ \\
\hline
\end{tabular}

COMMENTS ON PARTICULAR TEST QUESTIONS

\begin{tabular}{|c|c|c|}
\hline & $\begin{array}{l}\text { Before - BEST Short } \\
\text { Form }\end{array}$ & After-BEST Long Form \\
\hline Greetings, Personal Information & 1. -5 . & 1. -8 . \\
\hline Describe Common Situation & 6. Home situation. & 9. -10 . \\
\hline Time/Numbers & 7. Time. & 11. -13. Time recognition. \\
\hline & 8. Tine get up perfeet. & 14. Time set up. \\
\hline Directions, Clarification & 9. -16. & $15 .-23$ \\
\hline Money & $\begin{array}{l}\text { 11. Does recognize } \\
\text { money. }\end{array}$ & 23. -26 \\
\hline Shopping, Food, Clothing & 10.12 & 27. -28 \\
\hline Signs & & 29. -32. Cannot read 4 \\
\hline $\begin{array}{l}\text { Emergencies, Safety Health, } \\
\text { Body Parts }\end{array}$ & 13. -15, One wrong. & 33. -41 \\
\hline Employment, Training & 18. & $42 .-45$. \\
\hline
\end{tabular}




\section{LONG FORM}

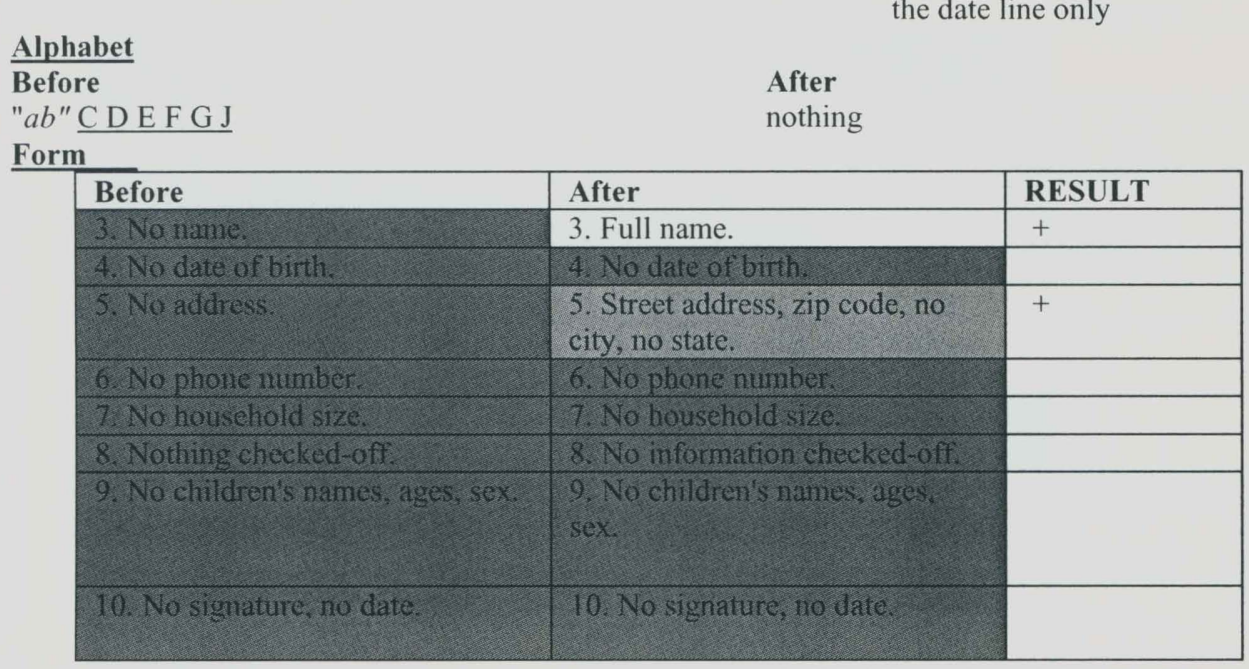

46-49 Form - 0 pts. Signed first name on the date line only

\begin{tabular}{|c|c|c|}
\hline \multicolumn{3}{|l|}{$\begin{array}{l}\text { Alphabet } \\
\text { Before } \\
" a b " \text { C D E F G J } \\
\text { Form } \\
\end{array}$} \\
\hline \begin{tabular}{l|l|} 
& Before \\
\end{tabular} & After & RESULT \\
\hline 3. No name. & 3. Full name. & + \\
\hline 4. No date of birth. & 4. No date of birth. & \\
\hline 5. No address. & $\begin{array}{l}\text { 5. Street address, zip code, no } \\
\text { city, no state. }\end{array}$ & + \\
\hline 6. No phone number: & 6. No phone number. & \\
\hline 7. No houschold size. & 7. No household size. & \\
\hline 8. Nothing checked-off? & 8. No information checked-off. & \\
\hline 9. No children's names, ages, sex & $\begin{array}{l}\text { 9. No children's names, ages, } \\
\text { sex. }\end{array}$ & \\
\hline 10. No signature, no date. & 10. No signature, no date. & \\
\hline
\end{tabular}

\begin{tabular}{|c|c|c|}
\hline Survey One for Somali Women & $\begin{array}{l}\text { Survey Two for Somali } \\
\text { Women }\end{array}$ & Changes \\
\hline $\begin{array}{l}\text { A. No print in English at the } \\
\text { home: }\end{array}$ & $\begin{array}{l}\text { A. No print in English in the } \\
\text { home. }\end{array}$ & \\
\hline $\begin{array}{l}\text { B. 1. Thinks learning English will } \\
\text { be difficult. }\end{array}$ & $\begin{array}{l}\text { B. 1. Thinks learning English } \\
\text { was difficult. }\end{array}$ & \\
\hline 2. Can read and write in Somali. & 2. Can read and write in Somali. & \\
\hline 3. Cannot read in English. & $\begin{array}{l}\text { 3. Can read in English - } \\
\text { beginning level. }\end{array}$ & + \\
\hline $\begin{array}{l}\text { 4. Can write the alphabet in } \\
\text { English. }\end{array}$ & $\begin{array}{l}\text { 4. Can write the alphabet in } \\
\text { English. }\end{array}$ & \\
\hline $\begin{array}{l}\text { 5. Cannot write sentences in } \\
\text { English. }\end{array}$ & $\begin{array}{l}\text { 5. Can write sentences in } \\
\text { English-basic 3-5 word } \\
\text { sentences. }\end{array}$ & + \\
\hline $\begin{array}{l}\text { 6. Cannot sperk on the plione in } \\
\text { English. }\end{array}$ & $\begin{array}{l}\text { 6. Cannot speak on the phone in } \\
\text { English. }\end{array}$ & \\
\hline $\begin{array}{l}\text { 7. Cannot fill out a job application } \\
\text { in English. }\end{array}$ & $\begin{array}{l}\text { 7. Camnot fill out a job } \\
\text { application in English. }\end{array}$ & \\
\hline $\begin{array}{l}\text { 8. Has family encouragement to } \\
\text { learn English. }\end{array}$ & $\begin{array}{l}\text { 8. Had family encouragement to } \\
\text { learn English. }\end{array}$ & \\
\hline $\begin{array}{l}\text { 9. Plans to spend more and } 1 \text { hour } \\
\text { a day studying. }\end{array}$ & $\begin{array}{l}\text { 9. Spent more and } 1 \text { hour a day } \\
\text { studying. }\end{array}$ & \\
\hline $\begin{array}{l}\text { 10. Looking forward to meeting } \\
\text { tutor. }\end{array}$ & 10. Tutor became a friend. & \\
\hline $\begin{array}{l}\text { 11. Studied English for } 2 \text { months } \\
\text { at IRCO. }\end{array}$ & 11. Tutor was a good teacher. & \\
\hline $\begin{array}{l}\text { C. Goals are "to be able to speak } \\
\text { on the phone. To be able to } \\
\text { communicate with my doctor } \\
\text { without an interpreter." }\end{array}$ & 12. Did not achieve goals & - \\
\hline
\end{tabular}




\begin{tabular}{|c|c|c|}
\hline Survey One for Tutors & Survey Two for Tutors & Changes \\
\hline $\begin{array}{l}\text { 1. Thinks terching English will } \\
\text { not be difficult. }\end{array}$ & $\begin{array}{l}\text { 1. Teaching English was not } \\
\text { difficult: }\end{array}$ & \\
\hline $\begin{array}{l}\text { 2. Feels comfortable with people } \\
\text { who do not speak English. }\end{array}$ & $\begin{array}{l}\text { 2. Feels comfortable with people } \\
\text { who do not speak English. }\end{array}$ & \\
\hline $\begin{array}{l}\text { 3. Feels comfortable entering a } \\
\text { Somali household. }\end{array}$ & $\begin{array}{l}\text { 3. Feels comfortable entering a } \\
\text { Somali household. }\end{array}$ & \\
\hline $\begin{array}{l}\text { 4. Can read or write in another } \\
\text { language. }\end{array}$ & $\begin{array}{l}\text { 4. Can read or write in another } \\
\text { language. }\end{array}$ & \\
\hline $\begin{array}{l}\text { 5. Hopes to become friends with } \\
\text { student. }\end{array}$ & 5. Became friends with student. & \\
\hline $\begin{array}{l}\text { 6. Plans to spend more than one } \\
\text { hour a day preparing lessons. }\end{array}$ & $\begin{array}{l}\text { 6. Did not spend more than one } \\
\text { hour a day preparing lessons. }\end{array}$ & + \\
\hline $\begin{array}{l}\text { 7. Has experience training } \\
\text { someone to fill out a job } \\
\text { application. }\end{array}$ & $\begin{array}{l}\text { 7. ESL training was adequate } \\
\text { "It was O.K. - not exciting." }\end{array}$ & \\
\hline $\begin{array}{l}8 \text {. Has worked with refugees } \\
\text { before. }\end{array}$ & $\begin{array}{l}\text { 8. Literacy teaching training from } \\
\text { LFS was adequate. }\end{array}$ & \\
\hline 9. Has not been to Africa. & $\begin{array}{l}\text { 9. Cultural training at LFS was } \\
\text { adequate. "Great." }\end{array}$ & \\
\hline 10. Has ESL tutoring experience. & $\begin{array}{l}\text { 10. Received adequate support } \\
\text { from LFS staff. "Great." }\end{array}$ & \\
\hline \multirow[t]{6}{*}{$\begin{array}{l}\text { 11. "I have an EFL Certificate } \\
\text { from New World Teachers School } \\
\text { in SF - 1996. I teach English with } \\
\text { a focus on health for Mexican } \\
\text { women and Somalian women for } \\
2-3 \text { years. Lived in Uruguay } 1 \\
\text { year in } 1993 \text {. }\end{array}$} & $\begin{array}{l}\text { 11. Student did not do homework } \\
\text { outside of tutoring session. }\end{array}$ & \\
\hline & $\begin{array}{l}\text { 12. Student did not achieve all of } \\
\text { her goals. }\end{array}$ & - \\
\hline & 13. Liked the program's cause. & \\
\hline & 14. Liked the program's content. & \\
\hline & $\begin{array}{l}\text { 15. Does not wants to continue as a } \\
\text { tutor. "I don't have the time." }\end{array}$ & - \\
\hline & $\begin{array}{l}\text { 16. Suggestions for other LFS } \\
\text { programs - "Exploring cottage } \\
\text { industries that women could } \\
\text { possibly start with skills they } \\
\text { already have. My student was } \\
\text { having a lot of somatic problems. } \\
\text { She and her husband struggle in } \\
\text { their new environment. Very } \\
\text { strong family bonds, husband-wife } \\
\text { relationship. I will continue to stay } \\
\text { in touch informally." }\end{array}$ & \\
\hline
\end{tabular}


Identification Name: $\mathbf{3 3 0}$

Tutoring Hours Completed: 62 hours (86\% of 72 hours)

First Test: $\quad 9 / 19 / 99$

Second Test: $\quad 6 / 29 / 00$

\begin{tabular}{|c|c|c|c|c|c|c|}
\hline & 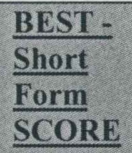 & $\begin{array}{l}\text { Total } \\
\text { Points } \\
\text { Possible }\end{array}$ & $\begin{array}{l}\text { BEST Short } \\
\text { Form } \\
\text { Adjusted } \\
\text { SCORE }\end{array}$ & $\begin{array}{l}\frac{\text { BEST- }}{\text { Long }} \\
\text { Form } \\
\text { SCORE } \\
\end{array}$ & $\begin{array}{l}\text { Total Points } \\
\text { Possible }\end{array}$ & Changes \\
\hline Total & 14 & 38 & $27 \mathrm{~V}$ & $48 \mathrm{VII}$ & 91 & +21 \\
\hline Communication & 10 & 20 & ----------- & 29 & 48 & \\
\hline Fluency & 4 & 18 & - & 13 & 24 & \\
\hline Listening & - - & - -.on- & 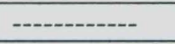 & 6 & 11 & \\
\hline reading/writing & - ----- & --------- & - - - & 9 & 8 & \\
\hline Alphabet Test & 3 & 41 & ----------- & 2 & 41 & -1 \\
\hline Form Test & Partial & Perfect & ----------- & $\begin{array}{l}\text { Partial- } \\
\text { better }\end{array}$ & Perfect & improve \\
\hline
\end{tabular}

\section{COMMENTS ON PARTICULAR TEST QUESTIONS}

\begin{tabular}{|c|c|c|}
\hline & Before - BEST Short Form & After-BEST Long Form \\
\hline $\begin{array}{l}\text { Greetings, Personal } \\
\text { Information }\end{array}$ & 1. -5 . & 1. -8 \\
\hline $\begin{array}{l}\text { Describe Common } \\
\text { Situation }\end{array}$ & 6. Home situation. & $\begin{array}{l}\text { 9. }-10 . \text { When asked, "What } \\
\text { is she doing?" } 330 \text { answered, } \\
\text { "I look the TV." }\end{array}$ \\
\hline Time/Numbers & 7. Time & 11. -13 . Time recognition. \\
\hline & 8. Time get up perfect & 14. Time get up. \\
\hline Directions, Clarification & 9. -16 & $15 \cdot-23$ \\
\hline Money & $\begin{array}{l}\text { 11. Does not recognize } \\
\text { money. }\end{array}$ & 24. -26 \\
\hline Shopping, Food, Clothing & 10,12 & $27 .-28$ \\
\hline Signs & & 29. -32 . Can read all 4 signs. \\
\hline $\begin{array}{l}\text { Emergencies, Safety } \\
\text { Health, Body Parts }\end{array}$ & 13. 15, One correct. & $33 .-41$ \\
\hline Employment, Training & 18. & 42. -45 \\
\hline
\end{tabular}




\section{LONG FORM}

Wrote name, address w/o City, State, Zip, Signed first name only, No date

\begin{tabular}{|c|c|c|}
\hline $\begin{array}{l}\overline{\text { Before }} \\
" a b \text { s b E F J }\end{array}$ & $\begin{array}{l}\text { After } \\
" a b s \mathrm{~d} \text { c if } \mathrm{j}\end{array}$ & \\
\hline \multicolumn{3}{|l|}{ Form } \\
\hline \begin{tabular}{l|l} 
Before \\
\end{tabular} & After & RESULT \\
\hline 3. Full name. & 3. Full name. & \\
\hline 4. No date of birth. & 4. No date of birth. & \\
\hline 5. No address. & $\begin{array}{l}\text { 5. Street address, no city, no state, } \\
\text { "97" for the zip only. }\end{array}$ & + \\
\hline 6. Phone number. & 6. Phone number. & \\
\hline 7. No household size. & 7. No houschold size. & \\
\hline 8. Nothing checked-off. & 8. Information checked off & + \\
\hline $\begin{array}{l}\text { 9. Children's names, no ages, } \\
\text { no sex. }\end{array}$ & $\begin{array}{l}\text { 9. Children's names, (only one sex } \\
\text { written but all four children are male, } \\
\text { written "mail", and ages. }\end{array}$ & + \\
\hline $\begin{array}{l}\text { 10. Signature - first name only, } \\
\text { no date. }\end{array}$ & 10. No signature, no date. & - \\
\hline
\end{tabular}

\begin{tabular}{|c|c|c|}
\hline Survey One for Somali Women & Survey Two for Somali Women & Changes \\
\hline A. No print in English at the home. & A. Advertisements, school books. & + \\
\hline $\begin{array}{l}\text { B. 1.Thinks learning English will be } \\
\text { difficult. }\end{array}$ & $\begin{array}{l}\text { B. 1. Thinks learning English was } \\
\text { difficult. }\end{array}$ & \\
\hline 2. Can read and write in Somali. & 2. Can read, not write ir Somali. & \\
\hline 3. Cannot read in English. & $\begin{array}{l}\text { 3. Can read in English - beginning } \\
\text { level. }\end{array}$ & + \\
\hline 4. Can write the alphabet in English. & $\begin{array}{l}\text { 4. Can write the alphabet in } \\
\text { English. }\end{array}$ & \\
\hline $\begin{array}{l}\text { 5. Cannot write sentences in } \\
\text { English. }\end{array}$ & $\begin{array}{l}\text { 5. Can write sentences in English- } \\
\text { basic short 3-5 word sentences. }\end{array}$ & + \\
\hline $\begin{array}{l}\text { 6. Cannot speak on the phone in } \\
\text { English. }\end{array}$ & $\begin{array}{l}\text { 6. Can speak on the phone in } \\
\text { English. }\end{array}$ & \\
\hline $\begin{array}{l}\text { 7. Camnot fill out a job application in } \\
\text { English. }\end{array}$ & $\begin{array}{l}\text { 7. Can fill out a job application in } \\
\text { English. }\end{array}$ & \\
\hline $\begin{array}{l}\text { 8. Has family encouragement to } \\
\text { learn English. }\end{array}$ & $\begin{array}{l}\text { 8. Had family encouragement to } \\
\text { learn English. }\end{array}$ & \\
\hline $\begin{array}{l}\text { 9. Plans to spend more than } 1 \text { hour a } \\
\text { day studying. }\end{array}$ & $\begin{array}{l}\text { 9. Spent more and } 1 \text { hour a day } \\
\text { studying - } 2 \text { hours for } 2 \text { days. }\end{array}$ & \\
\hline $\begin{array}{l}\text { 10. Looking forward to meeting } \\
\text { tutor. }\end{array}$ & 10. Tutor became a friend. & \\
\hline $\begin{array}{l}\text { 11. Studied English for } 2 \text { months at } \\
\text { IRCO. }\end{array}$ & $\begin{array}{l}\text { 11. Tutor was a good teacher. "So } \\
\text { much." }\end{array}$ & \\
\hline $\begin{array}{l}\text { C. Goals are "to be able to speak on } \\
\text { the phone. To be able to } \\
\text { communicate with my doctor } \\
\text { without an interpreter." }\end{array}$ & $\begin{array}{l}\text { 12. Achieved goals. "Some things I } \\
\text { understood. I never used to know } \\
\text { how to say my address or talk on } \\
\text { the phone. I learned how to ask } \\
\text { questions - "Where are you going?" } \\
\text { I want to learn more so I can be } \\
\text { independent. I want my sons to be } \\
\text { educated. I now know the } \\
\text { importance of education. I cannot } \\
\text { help my sons. I want to put them in } \\
\text { a special school to assist them. }\end{array}$ & + \\
\hline
\end{tabular}




\begin{tabular}{|c|c|c|}
\hline Survey One for Tutors & Survey Two for Tutors & Changes \\
\hline $\begin{array}{l}\text { 1. Thimks teaching English will } \\
\text { not be difficult. }\end{array}$ & $\begin{array}{l}\text { 1. Teaching English was not } \\
\text { difficult. }\end{array}$ & \\
\hline $\begin{array}{l}\text { 2. Feels comfortable with people } \\
\text { who do not speak English. }\end{array}$ & $\begin{array}{l}\text { 2. Feels comfortable with people } \\
\text { who do not speak English. }\end{array}$ & \\
\hline $\begin{array}{l}\text { 3. Feels comfortable entering a } \\
\text { Somali household. }\end{array}$ & $\begin{array}{l}\text { 3. Feels comfortable entering a } \\
\text { Somali household. }\end{array}$ & \\
\hline $\begin{array}{l}\text { 4. Camnot read or write in } \\
\text { another language. }\end{array}$ & $\begin{array}{l}\text { 4. Can read or write in another } \\
\text { language. }\end{array}$ & + \\
\hline $\begin{array}{l}\text { 5. Hopes to become friends with } \\
\text { student. }\end{array}$ & 5. Became friends with student. & \\
\hline $\begin{array}{l}\text { 6. Plans to spend more than one } \\
\text { hour a day preparing lessons. }\end{array}$ & $\begin{array}{l}\text { 6. Did not spend more than one } \\
\text { hour a day preparing lessonts. }\end{array}$ & + \\
\hline $\begin{array}{l}\text { 7. Has experience training } \\
\text { someone to fill out a job } \\
\text { application. }\end{array}$ & 7. ESL training was adequate. & \\
\hline $\begin{array}{l}\text { 8. Has worked with refugees } \\
\text { before. }\end{array}$ & $\begin{array}{l}\text { 8. Literacy teaching training from } \\
\text { LFS was adequate. }\end{array}$ & \\
\hline $\begin{array}{l}\text { 9. Lived in Africa } \\
\text { Mogadishu, } 1 \text { year, 1964, } \\
\text { Worked in US Embassy. }\end{array}$ & $\begin{array}{l}\text { 9. Cultural training at LFS was } \\
\text { adequate. ("It was wonderful.") }\end{array}$ & \\
\hline $\begin{array}{l}\text { 10. Has ESL tutoring } \\
\text { experience. }\end{array}$ & $\begin{array}{l}\text { 10. Received adequate support } \\
\text { from LFS staff. }\end{array}$ & \\
\hline \multirow[t]{6}{*}{$\begin{array}{l}\text { 11. Tutored Hispanic, Russian } \\
\text { and Ukrainian children, one } \\
\text { parent. }\end{array}$} & $\begin{array}{l}\text { 11. Student did not do homework } \\
\text { outside of tutoring session. }\end{array}$ & - \\
\hline & 12. Student did achieve her goals. & \\
\hline & $\begin{array}{l}\text { 13. Liked the program's cause. } \\
\text { "Very much. I help at a local } \\
\text { school. If they want her to } \\
\text { communicate with the school. It is } \\
\text { a job out of it - to go the store. }\end{array}$ & \\
\hline & $\begin{array}{l}\text { 14. Liked the program's content. } \\
\text { Ended up buying the next level of } \\
\text { the book. }\end{array}$ & \\
\hline & $\begin{array}{l}\text { 15. Wants to continue as a tutor } \\
\text { and is tutoring at Cleveland High } \\
\text { School with the homework club. }\end{array}$ & \\
\hline & $\begin{array}{l}\text { 16. No suggestions for other LFS } \\
\text { programs. }\end{array}$ & \\
\hline
\end{tabular}


APPENDIX E

NOTES FROM THE TUTOR'S DINNER PARTY 
Participants of the Discussion:

Tutors' Dinner Party 1/5

$1021,1101,1201,1041,1601,1701,1801,2101,2201,2401,3501$

2101: We cancel and go shopping. We have covered all of the malls.

1401: We have not met many times. Three times. It's not surprising. They told me quite a bit the second time I saw her.

2401: It is easier to talk about difficult things with a stranger.

1401: We have only done seven or eight hours all together. 140 is getting counseling. The last few times, her daughter has come. Five or six women show up. They come to visit her when I tutor.

3101: 310 is really down. When she is feeling good, she has headaches. She saw so many people killed. She won't go anyplace where there's many people. 280 is in a class. The husband works. "English hard, English hard." She gets alive when she says something in Somali. We had a conversation. Her daughter is in San Francisco and her sons are in high school. Her affect is flatter when she talks to her sons. They mess up the kitchen. Her husband has been on ships. She was separated from him for five to seven years.

3501: She's having problems with her sons. She's worried that jail or anything could possibly happen.

3401: 160 is getting psychotherapy. Maybe she will be declared disabled. The anxiety creates work. Multnomah County is putting her on anti-depressants.

3101: With PDST, what are looking for?

3401: We're starting parenting groups. We're not telling them it's group therapy.

1601: We're (Americans) the weird ones making group therapy.

3401: The case managers said they (the Somali women) need anti-depressants. The F.D.A. validated the PSTP. 110 is gone for three weeks. Rose City Village is starting E.S.L. classes March ${ }^{\text {st }}$. At 210 's house, we will have parenting classes. 110's son no one can stand her son. She has no patience with other Somali women who do not want to learn English. She's getting an attitude. The other Somalis say that she thinks she is too American. Her husband works two jobs. 1021: 102 was pregnant. We went one hour. It worked well. She focused and got a lot out of it. 102 had a girl. We're stating again next week. We stopped at the beginning of September. I visited there 
Tutors' Dinner Party 2/5

twice and talked with her husband. I now love tea. One lesson we worked for 10 minutes. Another meeting after 20 minutes she said, "I'm not feeling well." Later she would go for two hours.

2101: She taught me how to make bread and tea. We would go to Halal.

2401: I just found out that 240 had 9 children. A second-grade friend of one of 240 's children was over.

I am surprised how fast she learns things - how excited she is. She read the story. She has good writing skills and she writes small letters. 240 must work on it - she must review of the week before. She's prepared. When she wrote her name in the book on paper, she was thrilled.

1401: She (140) will not talk to me on the phone. She is starting by recognizing her $A B C$ 's. She says " $x$ " instead of " $h$ ", "c" instead of "a" and double d's.

3101: 310 's husband said I am too soft with 310 . I must do more. I am sure that she won't respond positively. At first we started with the books. She started teaching me Somali. The husband said, "You can do better than that." He made a goal. We have a lot of that.

1801: We jabber, jabber, jabber.

1401: I'm still not sure that she really wants to do this. But when we do it together, she seems to easily do it. Maybe because she's not feeling well. I find this very draining and very tiring. I work during the day and I go in the evenings. Maybe then she does not do well. It makes extra long days for me. Her daughter has been calling me and said her mother's life is complicated and hard. I feel tentative. She feels tentative.

2101: She is very much a little girl. She is 21 years old with two children. It's like my 16 year-old's friends. She says, "Let's get out of here." It's an isolated existence. We talk at the store. We're forging a relationship. So we didn't really work this week. Life goes on. I wonder how much she wants to learn to read and write or have an outside source. It's so loud. The phone is always ringing.

3501: It's a break for them from the kids.

2101: If feel like I am not doing justice by her. We don't meet as often as we should. I just feel that I am not doing well by her. We don't meet as often as we should. We're starting at the very bottom - numbers, ABC's, phonics...her basic. She didn't read in Somali either, We are starting to work with money. When she makes a 
Tutors' Dinner Party 3/5

mistake and gives me too much money, she never does it again. I keep thinking I'm not able to meet with her consistently. I envisioned that we would have the alphabet down by this time. If we go a step forward, then we go a step back. How much is that. You have to train your brain to learn. I guess that it's because of the inconsistency of the meetings. It's due to health problems.

3501: She has seizures.

2101: I want to make the daughter tell me. What she says and yells at the kids in English. With her in her situation, I don' know how important that she is learning how to write a sentence. I'll be ninety by the time we get in 72 hours.

1601: We are at 26 hours.

1021: We have done 27 hours.

2401: We are done tomorrow. 240 got upset. She asked me, "Are you leaving?" It depends on the person. Originally, we met for four hours a week.

1601: We have gone down to two hours.

3401: The program terminates May $31^{\text {st }}$. We need to figure out a closure procedure. The state said it was O.K. (to finish later.)

3101: 310 's daughter has glaucoma.

1041: 104 is 150 's daughter. She's so conscientious. She calls to leave a message when she can't meet. She got the time wrong. She can count to 30 .

2401: With help, 240 can count to 100 . You can see when the light goes off. She can use "s" for plurals. I use things like pictures and real fruit to abstract sounds. She can understand the abstract - man, paw, and other sounds.

2201: About 220. She thought you could sit there and do it. It was a disaster.

2401: We take two hours for every session. We read books. She can read vowel sounds. She has trouble with "p's" and "b's." I use the computer and magazines to get lots of different pictures. She holds the paper.

1041: I use little cards with letters for spelling. I have her write the word and write the sentences. The book is on the table. 
Tutors' Dinner Party 4/5

2401: I write down Somali words. 240 loves to write. She wants to write them down. She has to be working with them. The words. She couldn't get her phone number, how to spell Portland and how to spell the United States of America.

2101: I thought it would take forever.

(Level 0) She has her own way of writing. She doesn't know when to use capitals and lowercase. Now in all lowercase. Before it was all in uppercase. At age 50. I remember seeing in her face that she could do it. We compare. She is shy about speaking. 240 's $4^{\text {th }}$ grader reads at a $1^{\text {st }}$ grade level. They've been here 2 years. She counts on her $5^{\text {th }}$ grade son a lot. I can't get the kid's names and who was who? Back a year or so. They're all in ESL classes in the camps. The brother - he should be below - 10. It bothers her more than the kids.

1201: $\operatorname{Her}(1201$ 's) sons are so handsome.

2401: 240 's son on Monday. She whacks him on the arm. He is in the $4^{\text {th }}$ grade. He fixes tea for us.

Around Christmas, we will stop for two weeks.

1201: Concretize it. Parenting curriculum - Islamic perspectives.

3401: Out of 4,700 refugees, 1,200 are Africans. 90,000 is the limit. $\$ 400,000$ ORR, to the State of Oregon - Department of Education -- Spoke with Mike Lehman. Ramadan - If you tutor them in the mornings, prepare the Somali women for Y2K. Chew -leaf. Illegal narcotics in Yemen.

1601: I called and went to the AFS office. 160 is working hard. She needs a lot of repetition. I was a little envious. She's delightful.

We do exercise. We jump, we walk, we are waving our hands. Touch your toes.

1301: Her (130) husband was shot. She says, "I'm too old to learn." Half.

3401: On plastic. OPB Store of Knowledge.

3501: So many have gained a lot. They feel better. You're their first contact with Americans. They've had a nice period. Now they are ready for a small group. You guys have been incredible. Ending is scary for them. They feel sad as it's going to end. 
APPENDIX F

MID-TERM TUTOR QUESTIONS AND ANSWERS 
Developed 12/12/99

Somali Thesis Mid-Term Questions for Tutors

1. How is your experience so far?

2. Are the materials adequate for teaching your student?

3. Did the training prepare you enough for tutoring?

4. How much preparation time does it take you?

5. Do you see your student progressing? Do you consider this progress fast or slow?

6. Is the environment good for teaching?

7. Do you have anything else you would like to say?

\section{Midterm Question Answers}

1021 about 102

\section{How is your experience so far?}

It's been great. Very good. Around October and November she had a baby. We still have a lot of hours to go. We will start again next week. She's a motivated and a very bright woman. She'd know a lot more if we had worked more.

\section{Are the materials adequate for teaching your student?}

I use a lot of supplements. I made copies. The books were not complete. The books are good from prompting and introducing a tense.

\section{Did the training prepare you enough for tutoring?}

I only attended the cultural orientation. It was great.

\section{How much preparation time does it take you?}

I need at least 30-45 minutes for each lesson. It depends on how much I use the book.

5. Do you see your student progressing? Do you consider this progress fast or slow?

Yes, definitely - faster than I was lead to believe. She's very good.

\section{Is the environment good for teaching?}

Yes. It wasn't the best initially. 3501 called and now the husband babysits.

\section{Do you have anything else you would like to say?}

I am really pleasantly surprised. It's very satisfying. I watch the progress she makes and watch other try very hard. Even on those nights when I'm tired, I leave with more energy. I'm talking this up with my friends. 
1041 about 104

$2 / 31 / 00$

1. How is your experience so far?

Good. It's been really positive.

\section{Are the materials adequate for teaching your student?}

Yes. I think that it is. The book seems to go long with what I need. I put my own twist on myself. I learn a lot by talking to another tutor, I keep in touch with 2401 . She gave me ideas. The Dr. Seuss book. I think that it will be a good tool. I get more and more amazed by how much she does know and what she seems to be learning Now when I go to explain something, instead of showing her a picture, I talk about it. Somehow the skills are there.

\section{Did the training prepare you enough for tutoring?}

Um well, no matter what I always feel like I was thrown into it before I had experience. It was just one day. I can't say it was enough. I can't say it did a whole lot.

\section{How much preparation time does it take you?}

For one session, I probably say one hour for every two hours.

\section{Do you see your student progressing? Do you consider this progress fast or slow?}

I don't know. I think that it has been pretty fast. The spelling - we've been writing sentences. I know have been writing full sentences. Knowing what question is which at question mark. And a sentence with a period at the end. She writes well. She still has one thing I get frustrated with sometimes. There are certain words she can throw out there. I do a lot of repetition. And she can't do it. Aging - it becomes frustrating she gets frustrated because she thinks she should know it.

\section{Is the environment good for teaching?}

Yea - think it's good I enjoy being in her home because I get to learn more about her. I think it has been good. I have only had one situation where she was completely not just paying attention and I ended up leaving 15 minutes early. It was only one time.

\section{Do you have anything else you would like to say?}

Yes. I have to tell you this - one thing that I really enjoyed most of all is how I learned a lot about her. I went over there the day before he day before Ramadan. She painted henna on my hand. I enjoyed that last weekend after tutoring. She made me tea and I sat and watched a Hindi movie for 15-30 minutes. They know everything that's going on. I liked to being on the other end. I enjoy it. 


\section{1 about 110}

\section{How is your experience so far?}

It's been kind of up and down. Getting to know my student, my friend, has been enjoyable.

\section{Are the materials adequate for teaching your student?}

Well -um I think that yes, they are. I am realizing they are now. I was trying another way. Recommendation going back to it and try it out. I haven't seen any progress. Some, but its really hard to have consistent meetings. Both, I had surgery. It was difficult to communicate when we were going to the house. Her not hearing me at the door and also she does have childcare when we meet. We tend to get disrupted many times by the children. I love them.

\section{Did the training prepare you enough for tutoring?}

The training that I took - it, yes, I think so. I think it's going to help me when you first go. It was good. At first you can't. I didn't take it just until a month ago.

\section{How much preparation time does it take you?}

Um it ranges from 15 minutes to an hour -- one time I teach more than one hour and sometimes I do about an hour.

\section{Do you see your student progressing? Do you consider this progress fast or} slow?

I think it's slow it's somewhat progressing. It's inconsistent up to a month. I informed Lutheran Family Service about that. There was not other tutor available. They just said to tutor her. Now I can walk.

\section{Is the environment good for teaching?}

\section{Do you have anything else you would like to say?}

Um I wish I had more time after a long day at work. I wish I had more energy. It is hard to do it. She has three children. She's tired also. Our energy level is low on both ends. I wish I had more time. I am going to continue now that I'm O.K.

The reading I'm not sure about. She's an advanced beginner. I have never had her read a whole paragraph. This is my first time ever tutoring every day. This is all new for me. I feel bad most of the time. She likes me she says. I just want to make it more systematic. More than talking and writing words. I can pull what we did in the last three months. The kids (at work) really exhaust me. You need a lot of energy to tutor. Sometimes I tend not to give my best. More structure will give me less preparation to do. 
1201 about 120

Phone interview, 8:15 pm, Tuesday, January 25, 2000

\section{How is your experience so far?}

It's going pretty good. We haven't done it since Ramadan. Her daughter got sick. It's been a while.

\section{Are the materials adequate for teaching your student?}

Yea. The only thing I worry about. I know that repetition is important. I sense that she is getting bored with it. I get children's books and the phone book.

\section{Did the training prepare you enough for tutoring?}

I think so.

\section{How much preparation time does it take you?}

I don't do much prep time. About 20 minutes and I try to bring something else. I do bring word lists.

\section{Do you see your student progressing? Do you consider this progress fast or} slow?

I think she is. If we wouldn't have missed all this time she should be on target. We missed a long time.

I think she's doing O.K. She's also in PCC. She tries to do things on her own. She goes to the school to talk about her kids. She isn't afraid to talk with teachers.

\section{Is the environment good for teaching?}

It is for the most part. The kids are there. They turn the down. The youngest is five and she studies with me.

7. Do you have anything else you would like to say?

She's got a lot going on. It's not always a priority. We met with the principal and counselor about her son not going to school. He's still not going. He says he likes it. He's a sophomore. 
1601 about 160

1. How is your experience so far?

It's like the law. I've put in 28 hours so far. But she had been ill a lot. It is slower than I would have wished. She can only work for an hour at a time. I was in She needs a lot of repeating to get good with the numbers first.

\section{Are the materials adequate for teaching your student?}

I am not happy with Laubach. I don't know enough to stray away from it - especially concerning the alphabet.

\section{Did the training prepare you enough for tutoring?}

Yes, it was a good training.

\section{How much preparation time does it take you?}

It takes two to three hours for each hour. I make detailed notes after the tutoring. I do an outline the night before or the morning I go to tutor.

\section{Do you see your student progressing? Do you consider this progress fast or} slow?

It is slower than I expected. This is a lady with a lot happening in her life.

\section{Is the environment good for teaching?}

Yes, yes, it is very nice. I arrive at $10 \mathrm{am}$. The children are off at school. The children are a great help. The daughter helps to arrange the sessions. I kept showing up and 160 was sick. Now she is much better.

7. Do you have anything else you would like to say? 160 is a charming lady. 
1701 about 170

March 5, 2000

1. How is your experience so far?

Very positive - extremely. More than half way --- We scaled back to one evening a week - two hours. I became very weary. It was all right with my student. I work a lot of overtime. I work 6 days a week. She was very gracious. I really appreciate my student she loves to learn she's very interested in improving her communication skill. She's a forward thinking woman. She has goals. She want to take computer classes, she takes care of 3 teenage children at home. She has things she wants to accomplish.

\section{Are the materials adequate for teaching your student?}

They were not. She was above that so I purchased some things on my own. I went to Oregon Literacy to buy the books.

\section{Did the training prepare you enough for tutoring?}

Yes, it did help tremendously. I highly recommend it. I think my student by and large has a grater command of the English language than other woman in the program. Or she's right there in the top groups. I taught ABE, but 170 is the first time I've been involved in ESL.

\section{How much preparation time does it take you?}

Really not much in that as I say, she has a command of English and the material. I bought it from Oregon Literacy. It is very self-explanatory. Just sitting together and going through page by page. We review the words the - for me it's not a big deal.

5. Do you see your student progressing? Do you consider this progress fast or slow?

Oh yes. I observe. She's making progress. I think it's. I don't know how to gauge it. She's making very steady progress.

\section{Is the environment good for teaching?}

Yes, I'm going to her home. It's generally quiet. We sit at the dining room table. The teenage children are either in their rooms or with friends.

\section{Do you have anything else you would like to say?}

Um, I don't think so. I appreciate the opportunity to be involved in this project and I intend to fulfill my commitment, of course. I'm sure that my student and I will go beyond our 72 your hour commitment. I would also understand if she would need another tutor. It wouldn't hurt my feelings. This is about her and what she wants to do and what how she wants to live her life here. I know she wants to learn how to drive a car, become a citizen. I can't do all of those things for her. It's about her. My student speaks beautiful Italian. She's trying to teach me. She speaks lovely Italian. For example, she sang me a lullaby in Italian. She has a very gracious manner. Very sensitive. At the end of our time together, she always fixes me 
something to drink. Generally it is a fruit juice. Sometimes she bakes a beautiful sweet bread.

On my first visit with her was I was a half an hour late. I called 170 that evening. Part of time is conversation. We have about an hour and 15 minutes of real study. But I find that two four hours of hard study is too much for student and the instructor because is it is at the end of the day with her children and after my work.

\section{1 about 180}

1. How is your experience so far?

Truly overwhelming. Good. She has blown my socks off. She blows me away as a person. She's widowed and has two sons in Somalia. She takes care of six children here. Our relationship is so good.

\section{Are the materials adequate for teaching your student?}

Yea. The beginning is beyond her. At the first lesson, I didn't realize her capacity. The books are a little below her. She has trouble with the "TH" sound. I draw things out. Most of the time we work on her PCC homework, pronunciation and "be" verbs. I mix it up with books from the library. I go to the ESL section at the Multnomah County Library. There's so much variety. I feel it's consistent.

\section{Did the training prepare you enough for tutoring?}

Yea, it was good.

4. How much preparation time does it take you?

I do less now with the PCC materials.

5. Do you see your student progressing? Do you consider this progress fast or slow?

Not fast. I do see her progressing.

\section{Is the environment good for teaching?}

Yes, her house is good. We meet at 9-11 when her children are at school.

\section{Do you have anything else you would like to say?}


2101 about 210

1. How is your experience so far?

It's really wonderful.

2. Are the materials adequate for teaching your student?

We started out with the Laubach ESL. I then went to Laubach to get the regular book two - "Pathways to Math." We started cursive writing.

\section{Did the training prepare you enough for tutoring?}

I had tutored before. I enjoyed having the training. I enjoyed the cultural training. I think that it would be good to have a medical person talk about PTSS. Even if I don't know what 210 has been through.

\section{How much preparation time does it take you?}

I spend a half a week preparing. I've been through the Dr. Seuss before. I use the teacher's book.

\section{Do you see your student progressing? Do you consider this progress fast or} slow?

Yes, sometimes it's fast, sometimes it's slow. We use the telephone and do conference calls to talk with the insurance.

6. Is the environment good for teaching?

No, because 95 percent of the time her kids are with us. They are good for a half hour and class is good.

7. Do you have anything else you would like to say?

It has been a wonderful program in my perspective. I've learned about a new culture, made a friend, and did something useful for somebody. 
2201 about 220

1. How is your experience so far?

It is fascinating. I like it but it's inconsistent.

2. Are the materials adequate for teaching your student?

They are not adequate. I created my own.

3. Did the training prepare you enough for tutoring?

The Somali cultural training was good. It was very valuable for me. I didn't go through the tutoring training.

4. How much preparation time does it take you?

We go very slowly though the material.

5. Do you see your student progressing? Do you consider this progress fast or slow?

Yes, it is slow.

6. Is the environment good for teaching?

No.

7. Do you have anything else you would like to say?

No. 
2401 about 240

1. How is your experience so far?

I still feel like she wants me to come. But she has headaches. Last time, we lost an hour. The kids are great. One is very bright. She speaks good English and shows me around.

\section{Are the materials adequate for teaching your student?}

They are way too structured for us. She needs more experimental and less writing. She needs basic information. She doesn't have much confidence. We play games and we laugh a lot - better than being tested.

\section{Did the training prepare you enough for tutoring?}

I already was teaching. It wasn't well presented. I could have been in a four-hour training. I heard about that mentioned. It's not my style. The materials don't relate to any parts of her life. For her, she wanted more telephone conversations. We practice. I try to respond to the requests she makes.

\section{How much preparation time does it take you?}

In the beginning, I tried to stay with Laubach. We lost momentum.

\section{Do you see your student progressing? Do you consider this progress fast or} slow?

Yes, she's slow. It has to do with the inconsistency. She does try to learn English with TV. When I came back from Ramadan, I found that her daughter had helped her study - getting the words down, repeating, knowing what those sentences are.

\section{Is the environment good for teaching?}

Yea, no little kids. She sets us aside. We have the chairs.

7. Do you have anything else you would like to say?

It's odd that they have never offered me anything to eat or drink. 
APPENDIX G

TUTORING OBSERVATIONS 
Tutoring Observations

\section{5:00 pm}

1041 sits down at table in the diningroom.

104 is on the phone speaking in Somali.

A child is crying.

The TV plays a children's program. The volume is low. One woman and a teenager is on the couch in the other room. An old Somali man visitor is also in the livingroom.

The children are happy to see 1041 and seem to like her very much.

\section{5:03}

1041 puts cards on the table.

A child is screaming.

104 tries to write and she erases her answers.

1041 shows 104 how to write the answer.

1041 points on the paper. A child climbs on 1041 's lap and sits on her legs.
1041: Do you have a pen?

104: Broken. You use that. That one. Works. Refill. Lead. Sister?

1041: Let's do day. Today's date. Today the date is. Put the date.

1041: Good. O.K. Good. Let's do. Today is. Today's date. Today's date. November, no? Now, today's date is. And just.

1041: O.K. Good. Today's date. Good. Four letters. Today's date. Good. What is that? Month. November. What is the date? Tuesday.

1041: 2000 years.

1041: Hi. Good. Good. O.K. So. Ban? Very good. So how many - one month? How many days? 29. Good 29 days. What is Thursday? How many days in a week? 
104: Seven.

1041: How many days do I work?

104: Five.

1041: Monday, Tuesday, Wednesday,

Thursday, Friday, Saturday. Sunday.

104: Weekend.

1041: Let's do days of the week?

104: Sunday, Saturday, Monday, Tuesday, Thursday, Saturday.

1041: We'll do it again. O.K. Sunday.

104: Sunday, Monday, Tuesday, Wednesday, Thursday, Friday, Thursday, Saturday. Sunday beginning of the week.

1041: Good. O.K., O.K. Now what is the month?

104l: Looks at a calendar with pictures of Oregon. A child walks around to look at me (the observer.) Then the child sits on her mother's lap.
104: February.

1041: Right, good.

104: Doctor? Doctor? She go to doctor? On Friday.

1041: Let's do words. I'll have you show me a magazine.

What's this?

1041: Book. This is a book.

104: How do you spell book?

1041: Double “o” $\mathrm{k}$.

104: Book. Book. This is a book. 
1041: What is this?

104: Pen.

1041: Can you spell pen?

104: P- E-N.

1041 puts cards out.

104: arranges cards. P E N C

1041: You spell pencil. L.

104: O? What letter O? E?

I. O.K.

104: shows the word pencil.

1041: Now this. Table. How do you spell table?

Several children start to play in the kitchen which is next to the student's table.

1041: Here's a "T."

T shows a card with a "T" on it.

104: T A B LE.

104 shows the cards on the table - "TABLE."

1041: O.K. So desk. Desk.

104 Shows cards spelling "DICK."

104: Cousin.

104 tries to get the child on her lap to go to another person in the livingroom.

1041 points to a chair.

Three girls come to talk to the student. 104 talks in Somali for one minute with the girls.

1041: Desk. _._ K.

104: I? A? E? C,

1041: Desk. Desk. C. C Deck. Deck. S. What's this?

104: Chair. Chair.

104: Chair. Chair. CA. CH. E. A. 
A child comes to speak to 104 again. Another woman brings Sprite for us to drink. A child asks M, "What's that?"

A baby cries.

Two other women come to take care of the baby.

[The cards show S__ D_N_.]

A baby comes and cries in front of M. 104 ignores at first. Then 104 picks up the baby.
An older daughter comes over and asks, "What are you doing?"

[T shows the cards T E _. R].
104: E. A.

1041 ; Good. Chair. Chair. A. I. Chair, O.K. Now

1041: we get to move on to something difficult. O.K. You are a . Student. Spell student.

104: It's a pencils. Pen. She doesn't feel well. Sick.

104: O.K. Student.

104: S. U. T.

104: S.T.U. Student.

1041: O.K.

104: S. U. STU. STUDENT. ST. STUDENT. STUDENT. STU. STU. D?

1041: Uh, hum.

104: A. I. E.

1041: Right.

104: N.T.

1041: Right.

1041: O.K. You are a student. And I am a

104: Teacher.

104: C.H.

1041: O.K. That's right.

104: I. A. 
1041: Teach. Teach. E. O.K. Teacher. Good. All right. $B$. is a . Not man

but

104: Boy.

1041: Spell boy.

104: B.O.Y.

1041: And S. is a

104: Girl.

1041: O.K. You spell girl.

104: G.A.

1041: O.K.

104: A. Oh?

1041: O.K. G is first. G.

Children start to sing to the TV. Cards show [G _- L.]

$5: 30 \mathrm{pm}$
104: M.

1041: Now. L. Right. L. So girl.

104: R.

1041: Right.

104: A.

1041: O.K. I

104: Girl.

1041: $\mathrm{S}$ is a girl.

104: S girl. 
6:10 pm

1701 hugs 170 .

170 's teenage daughter gives a Pepsi to all of us.

170 shuffles several papers and throws them around. 170 looks in several drawers.
170: How's your family? My son telephoned me. He left a message. His voice sounded good. He drives a big truck. He will be back home in a month - 30 days. He will be back in 30 days.

170: So, it's better to sit close of them - not far away.

1701: How's your family? How's your foot?

170: Fine. All together it's O.K. I went to the doctor. He said we cannot do anything for it. The skin match. Inside of the veins it's transferred the fire. We cannot do for it. That is God will solve the problem. I put some solution every night.

1701: Yes, God will solve the problem.

170: I'm lucky. My fingers. Not used.

1701: Do you have anything you me to help you with tonight?

170: My letter for my Lutheran Service. My letter. I'm not pretty good write.

1701: We'll work together, O.K.? Show me what we have to do.

170: It's called U.S.A. I am question her and say you. I'm say I miss you.

1701: I'll write something. I'll have you write it.

170: She said when I leave. I miss you 170.

1701: Oh, let's say Dear L. How are you? How's your family? Do you want to tell her you're still studying English? I am studying.

170: English. How's you life? How is your school? 
1701: Teaching.

1701: Maybe you could ask her how many 6:26 pm

1701 writes the words on paper. student she is.

170: O.K. I'm talking about myself. I'm O.K. I'm healthy. All my family we stay here. I never get a problem from here - Portland.

1701: O.K.

170: I tell about my legs. My pain is O.K.

1701: Does she know about your legs? In October.

170: September two.

1701: On September $2^{\text {nd }}$.

170: Let's see. Write it for my pain leg. Uh hum. So I was, for example, I saw. I think about. I want to sent you. I never forget you. I'm sorry I'm writing so late.

1701: Say again.

170 holds her hands to her mouth.

170 touches 1701 on the arm.
170: This lady is the boss of them. And P. And A. And for example, other names I never remember. And another lady. Man. Man is a teacher of the school.

170: She has written her name. But I miss. So this lady it's become. I know. With a small. S.

170: And that woman. P. Has send me if you got some problem. I'm say. Put New York. Put New York.

1701: Yes. Anything else?

170: Goodbye.

170: I had. You had brought me before. 
170 Laughs. 170 's teenage daughter comes to ask 170 a question. 1701 writes the letter.

170 laughs with her hands covering her mouth.

170 coughs.

170 reads the letter aloud as 1701 listens. She uses her finger to follow each word as she reads the letter. She doesn't use her glasses to read.
1701: I'm going to change it. I just wouldn't. It'll be coordinated together. O.K. She' $d$ be proud. O.K. Can you read my writing?

170: I think so. Looks a letter.

1701: I'll write it so all you have to do it to copy it.

170: It's good.

1701: I'm going to go in a little bit. Can you read my writing?

1701: You ask a lot of good questions. You said you never have problems in Portland, huh?

1701: Now we're going to finish the letter. This is what we say. Convey my greetings to $\mathrm{M}$ and.

170: O.O.O. Yes, he's working in there. It's manager for us.

1701: Is that is last name? Please write to me. Goodbye.

170: And write on the envelope. And write the telephone.

1701: Put your address too? Are you sure she has all of your information? 503. We put these in parentheses.

170: And the post. Post. It's hard to get the number for mail? Yes, my post office.

1701: That would be your. See if you can write that.

170: Just is clearly. Clearly. Clear. 
170 laughs and giggles loudly.

170 goes in the kitchen to get an envelope.

Goes to the refrigerator to get something.

170 covers her face as she laughs loudly.

1701 writes down what they have done so far.

170 laughs loudly.

1701 and 170 start to use the Side by Side E.S.L. textbook.
170: My leg is hurting. Healing means swell.

1701: Healing. Getting better.

170: Connecting my besta.

1701: Best.

170 reads with having her finger on each word.

1701: That's a very nice letter. Do you remember how to write the envelope?

170: Just I bring you.

1701: Your name and address go here.

170: Make me fast one. Make me. This I will copy. You are clever than me.

1701: Thank you.

1701: Do you?

170: Uh huh. How my this needs?

1701: One, only one. Pick out the one you would like.

170: Berries. That's good. It's very nice. I've never see.

1701: Have you tried strawberries before?

170: I have never tried. It's O.K. 1701. Already I move in here. She was really, really happy lady. She was the help.

170: The refugees was. They were O.K. Thank you so much.

170: This is not a nice house. 
1701 and 170 go through the true/false questions in the book.

170 looks for answer in the text.
170: Thank you.

1701: I want you to be happy. You've got the paper you need. You tell me if you need some paper.

170: Ramirez. San Juan (pronouncing the j.)

1701: San wan. Don't pronounce the j. Any words you want to ask me about?

1701 (to me): I like spending time with 170.

170: Henry. Where are you?

1701: I see Henry.

170: $\mathrm{Mm} . \mathrm{Mm} . \mathrm{Mm}$. Where are you?

1701: You are correct. It is untrue.

170: The students in my English class are interesting. Very interesting. Two carpets. Old furniture. Nothing matches. The kitchen is clean. 
[1701 helps 170 with correct pronunciation of $\mathrm{r}$ ]

170's daughter smiles and says hello to 1701.170 yells at the children asking questions.

170 laughs.
170: Mexico City.

1701. Mexico sity.

170: O.K. Nice voice again.

170: Before? Before when I was in Somalia? I was teaching in Italian language after I was married. I never study anything before. After that, Italian and private school. I was trying to study. The Somali was ruling. Italian so they was using their culture after that. The president he was ruling with a revolution. When he was ruling, Italian layer. I was study Italian before. I was busy for the children. The wasn't Somali. When they grew up the children I was trying to reaching something. When the children going to school I was helping their homework and try to figure out.

1701: You can go to college.

170: I am graduate. Very happy. Maybe possible. 
170 writes [Henry is

Chenesse.]

1701: You want to begin tonight? Henry is Chinese.

1701 does not teach the

170: Henry is Chinese.

correct spelling.

1701: Let's do dictation.

170: Henry is Chinese.

1701: George is Greek. Period at the end of a sentence?

170: Period? What is that?

1701: Nicole is French. She comes to Italy.

1701: My friend Marie and I are Mexican.

170: My friends?

1701: My friend Marie and I are Mexican.

170: Mr. and Mrs. Ramirez?

1701: It's a difficult name.

170: I'm in the house so I'm think about many problems. When I go out, I still don't know where the library is. I will find it. 


\section{APPENDIX H}

\section{TUTORS' FINAL COMMENTS}




\section{1}

Somali Thesis US Women's Comments $1 / 14$

I just really enjoyed the one on one connection with one woman. I'd feel that there was support for more materials and those things. It'd make it comfortable to continue

Suggestions for improvement:

It was hard for us to complete 72 hours. I don't know how realistic that may be.

Twice a week is pretty hard for a lot of people.

I would not like to continue as a tutor. Basically because I'm having a baby. I would do it again down the road. It's a timing thing.

I think that a follow-up program should include:

I think it would be good to continue with the same kinds of ESL training and also some these women seem to be open to learning new things about things in the US and skills that would help them getting around. Those kinds of classes to help them assimilate.

1601

[On friendship] I liked her. It didn't last - it is my fault.

I would not like to volunteer again. No - I'm gun shy. My problems were probably unique.

Follow-up program should include: Working on family planning, birth control is really, really important. Partner with Planned Parenthood.

1091

Yes, I didn't learn any Somali - Wait I learned tea and I learned a word for prayers but now I forgot it. so.. anyway, those were the only two words that I learned.

Tutoring was not easy but it wasn't difficult.

Student achieved goals? Yes, she did. She studied for her citizenship. She became a citizen.

Yes, because I lived in Mexico as a woman not knowing the language. And so I feel that in my own way I can empathize with a little bit what they are going through being a woman in a strange country and going through all of that trying to communicate with people.

Yes, I did. Um because it was just really user-friendly for me to be able to go into the lessons without having to do just tons of. If I wanted to do to augment what was there, I could but I didn't have to spend all my time just trying to get the basics put together. 
Um, I would. Just because it was a rewarding process and I feel like um particularly in the cause of women I feel thing that it's just an important thing to do - part of my responsibility.

Um, it was hard because my household wasn't necessarily a - probably was out of the norm where all of the children are adults and they speak English and they are helping to support the parents. So it's, um I believe 109 had an injury while I was working with her and I think that that was hard for them - just the whole access thing of the health care system. It's just so - it's hard for any of us let alone being a bit language challenged and culturally challenged on top of it. I'm really glad that I did it.

\section{1}

We have a very difficult language. There are many words. You take the same words and they mean two different things and it's very puzzling for them. I think it's difficult

The material wasn't for my student. She had had a survival course at PCC and was beyond the books they had given us.

Did you student study or complete homework? Not as much as she should have.

I really don't know. We're doing to continue working. She wants to go further. She seems to have a little bit of a learning problem. I use the Challenge Series which I got up at the Oregon Literacy Foundation and we went through the first book and it starts with the long vowel and the silent "e." She didn't seem to remember those. And we'd have another word with a long vowel and I'd say OK it's an "a," I want to hear an "a" and she would make every sound but an "a." She seemed incapable. I mean if I say the word, then there would be two or three more words that rhymed with. She'd get the first two and the third one or so, she would lose it again. And she's still doing that. I don't know how to get that to her. In other ways I think she's very bright so I think it might be just some kind of a learning disability. She'll sound out big long words but the long vowels she has a problem with. I don't know quite what to do about that.

My daughter's supposed to be checking out for me a Somali - English dictionary and I think that'll help her study at home. Her father and mother arrived month ago and she was expecting her dad to bring one and he didn't. And she does has some troubles with that. I can see. What are two words that she mispronounces and I don't want her to do that. It sounds like trash, English. Oh, I can't think what they are now. She can say it correctly. I keep reminding her. Her brother does - he pronounces it correctly and I know 
she can too. She's had so much on her mind towards the end of her pregnancy. Her baby was born on the fifth of February. Towards the end of her pregnancy she developed gestational diabetes. And that was a really worry to her. And her baby was born early and you know, having the new baby at home and a lot of the uncertainties and things. That did interfere too with. But she is dedicated. Her husband started to work with us when he was out of work for a while but then he got a job so he quit. He would learn very fast. I mean he was much better than she was. He didn't know what the words meant but he could pronounce them and read which was really amazing. I would have liked to worked with him. I think he would have learned very fast. Hopefully he has a job now.

Because anyone who plans to live in this country needs to speak English. There's no way they can succeed if they don't. And I think it's great. So many of the programs that are available - PCC, etc. are full. There's a waiting list. Women with children-how do they get over there? You know, so, yes, I think having them get into the home has been really good. And we do - we are friends and I'm going to stay with her. I want to make sure that little guy is bilingual you know. I mean he has to be. And with grandma and grandpa there and not speaking English I know he has to Somali also. So anyhow... I'm so glad that she got out of that other place. This is so much nicer-so much better for her. And her mother and dad are right next door with her brother. It is because they live with him.

They come over for meals and play with the baby. She'll have them really close. And do their laundry and things like that. I think it'll work out for them.

Well, I didn't really use the program per se. Every person you're working with is probably at a different level. I don't think I would like working with someone who is just basically totally - knew no English. I think that would be really difficult for me with my training. So I was glad to find she -- she understands so much more. Sometimes she can't put it into words and she can't recognize the written word.

Sometimes I think -- oh, I have to get up and get going but once I got there I just had such a good feeling about her and the baby and her husband and the whole situation. I could see how difficult it was for them. Isn't he gorgeous? She does have the most beautiful eyes also. 
Somali Thesis US Women's Comments 4/14

1201

In terms of my student and what the materials we had to work with and what she wanted to learn weren't the same thing.

Yea, you know my student really wanted more practical stuff like how to make a doctor's appointment and you know how to read a milk carton to see whether it's expired, you know, and we did some of those things and the book really didn't have that kind of material in it. You know how to talk to your child's teacher - that kind of thing. I don't remember (the training) addressing those kinds of things.

[Homework] She did a lot. She was really into practicing her letters. Maybe 15 minutes, a half hour every day. She also took PCC classes. Whenever I gave her stuff, she always had it done the next time. It was always - she just wanted to write words down and practice writing words. That was the big thing for her. She would just ask me, "Write this word down, write this word down. You know or point to something. Write couch. Write table." And she'd want to practice them.

Cause I think that self sufficient -- it's. I think that the empowerment is really important. That was really -- you know that that was how they're going to make it. 13. I would have to -- I'm middle ground there part of me would have to disagree with part of it. I wasn't that into the books. I wish we would have had more practical materials. Too much (tutoring set up ---hours.) I think there's maybe one or two tutors who've completed their hours. They went four hours a week. For the women, I think it was too much to arrange that with kids and such in that period of time. Originally it was supposed to be four hours a week for four months. I think maybe one person- Jackie did that.

Yes (continue) I think it's really a social justice issue. For people to really learn to speak a language gives people a voice.

Case management. Like, housing, medical, health, doctors, connecting to resources, information and referral, helping how to learn to work through systems. 
Somali Thesis US Women's Comments 5/14

\section{1}

Can I personally? I was in the Peace Corps - I would hate to be tested on it now.

I didn't go to the training. I just came out of the Peace Corps teaching ESL and I just (went right in?)

That's a really tough question. I'm getting my masters in intercultural relations. I'm working at international refugee center. I live culture everyday. Is there every enough training? No. OK? There's no way they could have. I work in a domestic violence program for immigrant and refugee women. But like I say, there can never be enough cultural training. It's a lifelong experience. There's not much they could have done. I mean how much could you teach American people if they have not been exposed to the Somali culture. How much could they do in, what was it a couple hours? They did a good job for what we were willing to sit down and listen to and everything, yea. I'm just saying that it is a lifelong study. You can't just learn it in two hours.

[support from LFS staff] It was there if I needed it. I just never requested it.

[goals] At the time yes, she wanted to learn how to write letters and she did learn how to write English so we did that. It's just that she got very sick and very pregnant and we were not able to complete - we did about a little over half of our time. And then she developed a lot of problems with her pregnancy and then had the baby and then it was - I think it was her sixth child and she pretty much collapsed. She's wonderful. She worked very hard while we were doing the lessons. She was very - well, I don't know if she worked hard or not, she was a very quick learner. Le me put it that way - very fast learner.

She was so proud to show her children.

I know her kids would sometime kind of uh - the oldest one and I'm not remembering all of the names now. But she us sometimes she's interfere and I knew that it embarrassed her mom. M. -- So I would try and keep her to the side because $\mathrm{R}$. was of that. That's good to know. for her. But I didn't know that she was proud

[Content] I used so many different books. I'd say it was fine. I think the reason I hesitate and I know that you just wanted agree/disagree. The most we would start with the book. We always reviewed where we had been and 
then we might just get a page or two beyond that . But I would have to say, for me, some of the best work we did was conversational and outside of the book. The book was fine. I think it gave her the confidence of writing. I think she liked the book better than I did. I think she liked the repetition and the writing and the stuff like that I'm guessing - You'd have to ask her. I had more interest in conversation that would help her on a day to day basis.

[Continue as a tutor] I can't right now. I would like to in the future when my life slows down a bit. But right now I am working 10-12 with refugee and immigrant women. I love it. I have nothing to spare. I'm drained, I'm drained. And I do it sometimes on weekends and in the middle of the night and I have nothing to give right now. OK? I thought that I was doing pretty well for a while then every once in a while when somebody's tortured in a basement and peed upon and all that sort of... It sends ya. You know. You do pretty well then all a sudden, you know, it might even take nothing for you to - you just weep for the world.

I love what you're doing. When I started it I had just gotten out of the Peace Corps I was on disability. I was not yet able to hold a job. I was able to sink a lot more into it. I just simply cannot. It is something I would again in the future.

[suggestions for programs] No, they did a good job. The staff did a really good job. My complements to them. Um some of the women were more committed than the others and I know that some of the volunteers were more committed than the others so I know. I would have to say that for a volunteer program and for women who had busy lives I think they probably did as well as they could. 72 hours was - when you have to start breaking it down into tiny segments, 72 hours started to feel like it was a real big commitment. I would often visit her for just - maybe an hour after work because that was all she could do and all I could do. Well, that's fine but it's a long time before you hit your 72 hour mark. But I would say that's not any fault of the program - no. It felt insurmountable and yet good things were happening. You know, I think I did 37-38. But I didn't count the times that I would just visit with her. So a lot happened outside those 30 whatever hours that weren't necessarily recorded. I mean when she had her baby, I brought her a baby gift and we talked. When there was a festival, this or that or something else, I tried real hard to get her involved in the Salvation Army Christmas project, da da da...So there were lots of things that 
happened that did not go into those 30 - some odd hours and I still felt like I was doing as much as I could. So 72 felt, well, out there.

\section{1}

I lived in Africa for $31 / 2$ years and I learned French. But the thing is that I spoke it. I didn't learn to read or write it. I learned. I didn't know it until I spoke it. I learned to speak it over there. I can read it but I don't usually chose to. I can read signs and stuff like that - like medical stuff - well, I was a health volunteer. But to sit down and read a book in French - no. But you can read it? -yea

[literacy training] I think the training was adequate but I wished I had - this is where maybe learning - maybe preparing would have helped more. But I wish that I had more tools to use that would be appropriate for a non-literate Somalian woman. I sort of had to make them up. What I did is that I got yellow stickies - the larger stickies and I would write the numbers I would write words. And I would have simple ones. And I put colors, I put members of her family, my name, basic verbs, very simple basic verbs like "is" you know stuff like that and colors like bus, and I would, we would create different sentences by rearranging the yellow stickies on her wall. Did she leave them up when you were gone, too? Yea, she did.

[goals] No. She wanted to speak English. We didn't get far in that at all. Because in ended up that her medical needs and social needs were so great that we concentrated on those and she got cataract surgery and had some other of her medical needs attended to. Because she had, so she um we realized that she could barely see. There was no depth perception. So, we concentrated on taking care. Rather than being a tutor it ended up being a caseworker.

[cause] I agree because I believe that as a nation we do have a responsibility to other countries and especially people in a refugee situation I mean our history and tradition has been an open door century. If we are going to continue in that open door policy because our world is so much more complicated than it was in the $17^{\text {th }} 18^{\text {th }}$ and $19^{\text {th }}$ century, $20^{\text {th }}$ century, I think we need to make sure that people that come into our country can survive adequately. We need to give them the tools.

[content] Well actually, as far as they (the materials) went, I appreciated them. But it would have been um I don't know what would have helped 
whether flashcards or. Because I don't know what would have worked better. It's real hard to know.

[continue tutoring] I would if I had time.

[suggestions for future programs] Activities of daily living. Survival skills in terms of how to use a telephone, how to use a calendar, how to put up appointments on a calendar. How to - Because a lot of these women has appointments they don't know how to. They have phenomenal memories but how to use a calendar. How to use basic things that we take for granted. You know, busses. I think they do pretty well. And little tricks like if you have medicine refills to call ahead. Don't want until they run out. If you can't make an appointment to call and cancel it. How to work with schools. Basically the teachers. Family meetings. What's expected of the parents. What the school expects of parents. So basically what our society expects of members our society that may be different to what they were used to. And it would help - it would ease their transition. That means like what does the medical community expect of patients which is call ahead of time for appointments and call if you can't make an appointment to call for refills before you run out. Um don't ever put how to take medicine you know - like if it says take one in the morning maybe have a chart with a sun rising uh, if it take one at night maybe have a moon with a symbol one or something. I mean just little things that would ease that would make things more understandable. Like one thing that she was doing. She was putting medicine from one medicine into another bottle. You know, stuff like that. And you know we just don't ever do that and when we're through with it we throw it away. We don't keep the container because it can be confusing and you shouldn't put other things in the container. Um, and even which household products are dangerous like they had a cat that had fleas and I - you had to tell them several times everyone has to leave, to cover the food for the flea bomb. And just little. And also where is the uh not the fuse box, whatta call it, how to flip the switch when the electricity goes off. One of the things that happened is that they blew out um a ceiling light because they were putting too strong a bulb in it. You know it was one of those that hangs. It was a chandelier type. And uh they were putting 100 watt bulbs and it said do not put anything more than 60 watts. Safety things that are really - so kind of like activities of daily living and safety tips for surviving. I don't know who is telling them whether it is word of mouth in their community or what. But now they know not to buy bulbs over 60 watts. 
I bought them a calendar and I said put every single appointment on this calendar. And then check it the night before. Check to see if you have any appointments. But the concept of a calendar is foreign because the Arabic or Koranic calendar is different. But trying - the kids know. The daughter has a much better idea of what a calendar is about and the granddaughter definitely knows who is thirteen. But somebody in the family needs to know what the calendar is for because that's one way - so now they've start putting things up like weddings, if there's going to be a wedding, if there's going to be a party. But I started for important appointments. Even at the end - at the bottom of each month I wrote down call to renew prescriptions.

I think they're a delightful group to work with. And I enjoyed it very much. I see them. Like today they were to go to a dental appointment at one and they didn't have any money to take the bus and I said. And they called me at five after one and I said well, S. what you have to do is you have to call the dentist I said do you have the number for the dentist? And she said, she went and looked for it. She said yes I do and I said you have to call them and tell them that you aren't going to make it. So she did so we hung up and I said and let me know and I said and reschedule and appointment, OK? And I said let me know what happens. So about three minutes later I heard the phone ring again and she said they're going to send a medical taxi for us. They're going to arrange to send a medical taxi, they were going to arrange to send a medical taxi so even though they'd be about 45 minutes late, the dentist must have had them come in. So um, yea, they call me for - you see it's the last day of the month and they have no money - I mean they get $\$ 434$ a month for welfare plus food stamps and their rent is something like $\$ 350$. So they've got to pay phone and electricity. So, and it was the last day of the month and they just didn't have any money to take the bus.

\section{1}

[goals] She studied for her citizen. She became a citizen.

Because I lived in Mexico as a woman not knowing the language. So I feel in my own way I can empathize a little bit about what they are going through being a woman in a strange country and going through with that - trying to communicate with people.

I liked the content because it was user-friendly for me. I didn't have to spend all my time getting all of the basics together. If I wanted to do things to augment it I could. 
It was a rewarding process and I feel like particularly in the cause of women, it is a very important thing to do. It's part of my responsibility.

My household was probably out of the norm. The children are helping support the parents. 109 had an injury while I was working with her. I believe it was hard for them - just the whole accessing the health care system. It is hard for any of us let alone being a bit language challenged and culturally challenged on top of it.

I am really glad that I did it.

\section{1}

Um, I would say somewhat in the middle I wouldn't say disagree or agree because sometimes we got material but I think we need more.

Somewhat agree on that right because I didn't finish the whole thing so...well, you know I haven't talked to her for a long, long time. (But at the time you were tutoring- ) Yes.

I have to say disagree because I went over to, what is it, PCC has like a class you take and it's like two Saturdays, if I am not mistaken, and you also focus on the you- know for the non- native speaker also, GED, similar to that so, you know, there's so many focuses and not enough focus on one thing.

[Literacy training] Well, somewhat disagree.

I agree on that one because I think because it's you know if you guys weren't focussing in on Somali women, who else is going to do it? And I thinks it's kind of you know just being in the community it helps because you know someone could say, "Well, it's not my problem." I think it's kind of nice. You don't look at their, um, beliefs, religions, backgrounds and say, well -- you're not trying to convert them into being Christians or anything like that. Because you know I have never done this. Lutheran Family Service is I think more tied to the church, I always think - there's always time to convert someone to be Christian. You guys didn't focus on that, anyway. I mean, you know, I was pleased with that.

Well, I think once again, just the focus on the goal here you know, of these women you know and the goal is to teach and do and speak and write and read English and you know otherwise they wouldn't have a chance to learn it with a stranger at all. They could probably learn it from their own family 
which could be positive and could be negative, you know. They have to interact with these tutors you know which is kind of nice you know I think make them You know how you have to listen to other people and you notice how other people speak different from the rest and it's kind of like I guess you could communicate a lot better. Um, I don't.

Disagree. I don't want to commit at all. No time now. I just don't have time you know. You think, well, three hours a week is not too bad but pretty selfish when you work fulltime I mean no way. I really admire people who go out and volunteer because it's like - you know I tried it and I found that's not what I want to do. 17 . See, this is my first time volunteering, I really don't. No more comments

\section{1}

Yes, very much because, this is a personal opinion, to not be able to read and write in one's own culture let alone in another culture makes me tremble inside. And so, I take it very personally. So, if I can help anyone with their reading and writing skills, um it's very rewarding for myself.

Um, I got to a point where I used some of my own books. And so I guess I will agree.

I am. Oh, how can I not? My student is so wonderful. She's such um a good student. She wants to learn. She's attentive. She's very diligent when we have our time together to do everything that I ask her to do and it's a little difficult for her to do homework because she still is very - three children in her home. And um I just want to be able to invest in her. I believe in her. I'm anxious for her to be able to be enrolled in some computer classes. She wants to learn computer. And her son Ahmed is taking a class at PCC. And I want that for her.

Computer classes, I think the opportunity to continue their English language classes beyond what the grant or that particular grant provided.

\section{1}

Some of these are really kind of difficult to answer because you don't know what other people's experiences were. My student - I don't know if it was a typical situation. Like doing the homework. I mean it would have been almost impossible for her. Well, she didn't know what homework was or what school was about. She had never been to school. She was in her sixties and I think her personal history did not lend itself to even understanding those concepts. Her daughters were there and they spoke English. They 
could, you know, they translated a bunch. It (the program) might have worked really well for other people. I think my student's personal history wasn't conducive to success the way it was set up.

Well, I mean she didn't even know how to hold a pencil. I mean just the concept of school and learning the way we Americans do it um she just had no reference points. I mean it's kinda like what are you doing here with homework you know it wasn't really a game. I mean god she's just a delightful woman and many times I felt honored even being in her home and seeing her culture you know and the family interaction and how highly respected and honored she was amongst her own people and then to kinda just plop her down in the middle of an American academic experience was just like insurreal in a way. Not that she didn't want to and that she wasn't capable of learning there was just set up that way with too much to overcome. Because I work so I could only go in the evening where she needed me or somebody to be there during the day when she didn't have distractions. There were teenagers in and out of the house and we were rarely alone.

Their - presence - you know - you can't pull that situation out of the setting.

[continue as a tutor] I would have to do it at a time when I really felt. The reason I quit is I knew that we were never going to be successful. Um, like I said there was just too much history. I mean if I had been somebody who wasn't working I could visit with her during the day and it could be kinda more of an on-going situation. But um, yea, I wouldn't mind doing something like this again but not in the same set-up. It was mostly a matter of scheduling. Oh, yea, it wasn't the program.

[question about tutoring outside of the home] Gee, that's such a cultural statement. Um, I think that's where she's comfortable, that's why I think that's important but like I said, she was a 61 year-old woman who had never been in a schoolroom. So, kind of throwing her into an uncomfortable situation I don't know if she would have learned better or not that's really difficult.

[new programs -1fs] In her situation, um the family, there were time I was just almost in tears because I know the school system is going to let down her children. It could almost make me cry now because they're beautiful, beautiful people. They have a wonderful culture. Their whole situation and being thrown into our school system expecting to live up to our standards and we are going to fail them and we are going to end up probably being on welfare and repeating a cycle and it's not their fault. I don't think as Americans brining people in that we support that. You know, fully 
inculturating them and setting a system up where they can't succeed because they deserve it and they're capable of it. But that's not how they're going to be perceived in our society. So that really bothered me. I think that they're thrown into our schools without the academic background. You know we didn't provide them any support for four or five years so they can. They going home and what do you mean study? You know, they just threw down an answer. I think sometimes the best thing I could of done was um actually tutor the kids. Be a mentor for the kids in making that gap. The girls are beautiful. One was a freshman in high school and one was in seventh or eighth grade.

But you know they could adapt much better than their mother. And that 's what bothers me is you know - I could just see their future. And they don't deserve that. You know. We brought them here and then we just kind of drop. It's kind of like you know you bring a kid from the farm into the city and you drop them off in a corner and say, well I got you here.

How did other people do? I can't see anything - you can go to PSU and read it in January.

I think I took a linguistics class last quarter at Portland State. I took basic linguistics. Wonderful, wonderful (teacher.) I was definitely intrigued. I didn't expect to like it. I think the training talking about culture and all that kind of stuff was kind of an exposure to this as kind of what to expect. But the basic of what linguistics is. It was really missing. You know, I mean I was sitting there just enthralled in class going oh my god you know that if you don't learn your grammar structure by the time you're three to five that you know that kind of stuff. And I went oh, no wonder I 'm having a difficult time with my student. She's wonderful. I like her. She likes me. Love the family. But know you I knew - I saw the handwriting on the wall.

Almost if you're going to have people teaching ESL, I think they almost have to have that as a required class. Just it was a population that needed special attention.

Um I think a little more formality would have been nice. Teaching out of the home like that I understand why they want it to be done. It lacks. It wasn't a very good place to be teaching. It was too hard with the kids around and the husband's around and craziness. It was too hard to teach.

Something more in the community room maybe at the mosque or community room of the apartment building. Make sure there's a time when the husband 
and the children are not going to be around. And make sure there's an actual space to study. We sat on the floor and studied and that didn't work at all. There was no desk to study on or anything. Stuff like. Just little things like that need to be figured out.

\section{1}

I spent a huge amount of time upfront - probably a good 12 or 16 hours all together preparing materials. But then it took her a long time and we never were able to get all the way through the material. With mine, she spoke no English. It was mostly pictures, and single words and things like that. There was no text for me to really use so.

I didn't really go through it because I was already a teacher.

I didn't know about this until the second day of the culture training so - I missed the first day because I didn't even know about the program.

Um, well I think it's worthwhile to help anybody's that going to be coming to live within the country to be able to function better in it and that's what we're trying to do. I think that's beneficial for not only them but for all the people around them as well. It's a win-win.

I think my student was probably the most English deficient of all the students in the group. Do I didn't use any of the materials they gave me because we were starting from square one. She didn't read or write Somali, either. So the materials they provided didn't work for her level. Because we were starting with very basics - just recognizing numbers and recognizing letters and stuff like that.

Not at this time - timing I don't have enough time. It's very time consuming.

I think it would be good for them if they don't already to dot it to provide cultural training for the Somalis about the culture they're having to live in now. Not that they to change the way they do anything but it might make it more understandable. I was - They have us background on religion and holidays and um, things like that. What was customary when you greeted somebody or went into somebody's home. What they teach us about the Somali culture would be very valuable in the reverse. So that they would know what to expect if they went into a non-Somali home. If they needed to go to the store - what would be customary. Routine stuff. 
I thought it was led by a group of very dedicated people and I have a lot of respect for them and what they're doing. I think it's tremendous. I just wish I had more time. It really does require a great time commitment. And that was difficult. One other thing that I would suggest for training for the volunteers.. My student was suffering from post-traumatic shock syndrome. And it would be helpful if I - I mean not knowingly had to work with anyone suffering with that and it would be helpful if they could give us a little bit of information about that and what we would need to do not to either aggravate it - it's not that we would be able to do anything to alleviate it. It's just what to look for and what. Because I knew nothing about it. I've heard about it and that sort of thing. I have no idea about you know if there's anything I should watch for or if there's anything that I would do to aggravate the situation. You know - unknowingly aggravate it. They feel a lot of pressure to perform well for their tutors. And you encourage them. And when is it too much encouragement so that they feel too much pressure so that it just - those kinds of things. And they all relate back to the post traumatic shock syndrome that they're going through,. They don't seem to be able to handle as much stress and strain. And it would be helpful to know about that. I haven't talked to her -- or her daughters -- for a month or so. 
APPENDIX H

STATISTICS 
$\underline{\text { Somali Women Statistics }}$

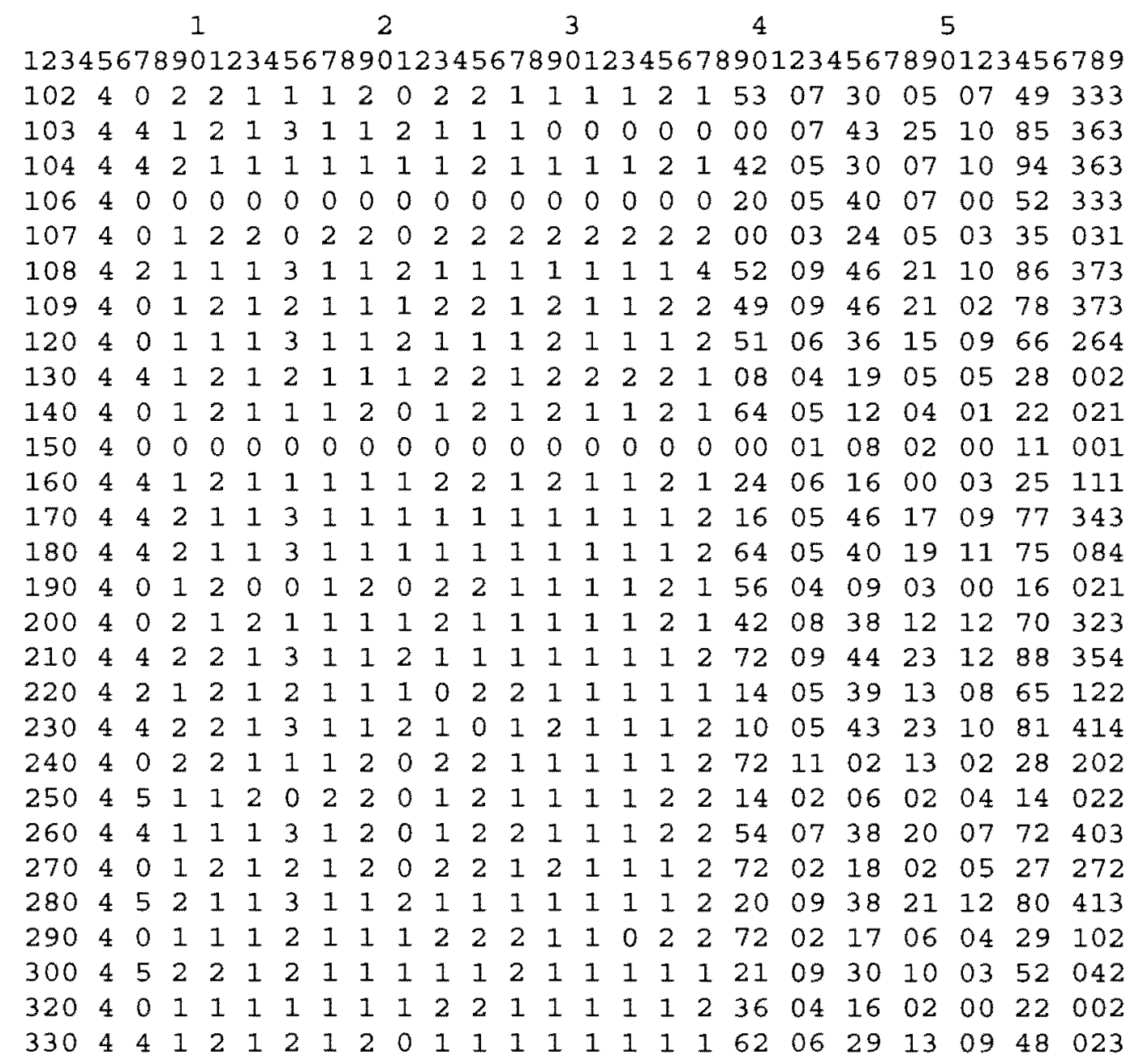




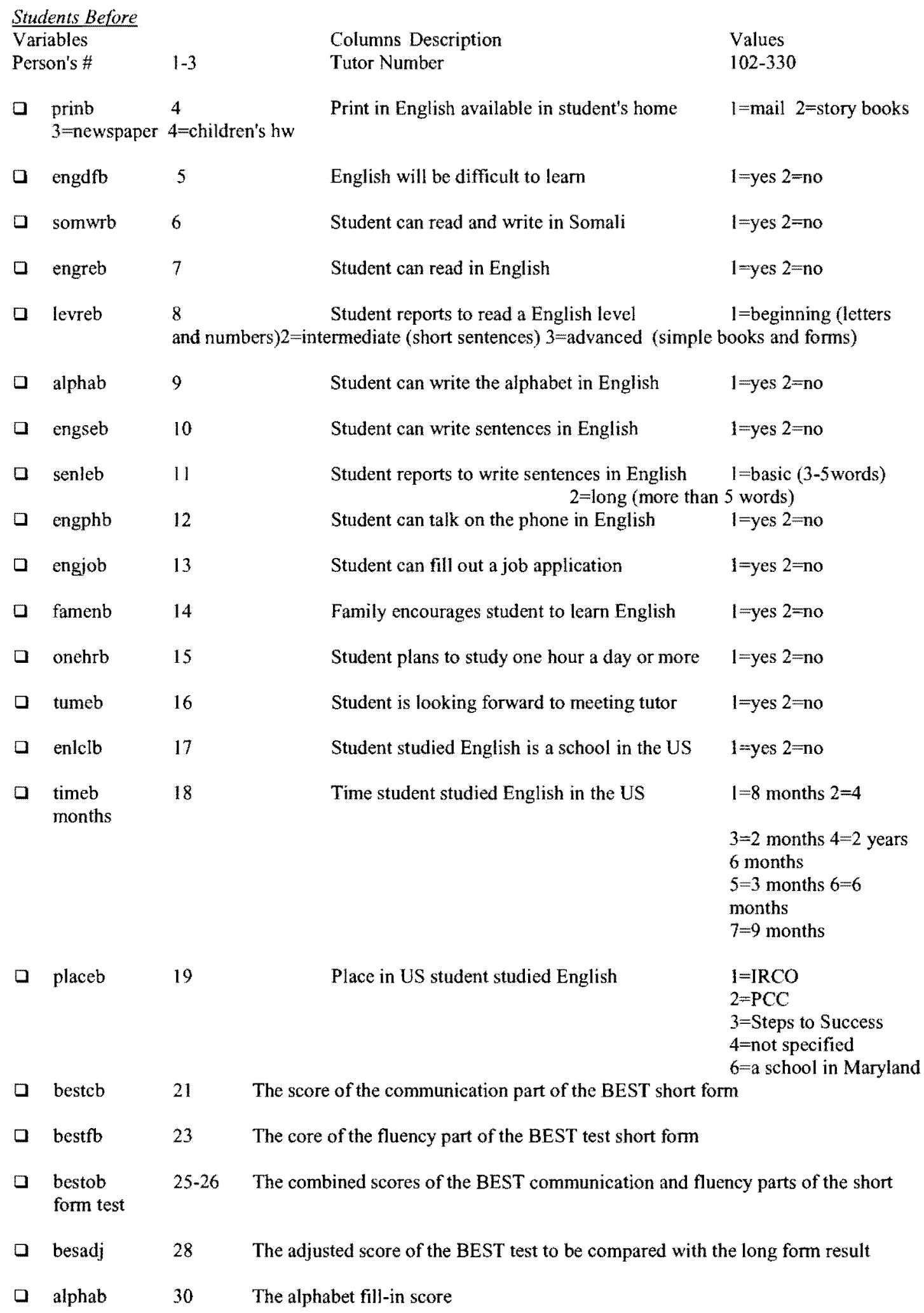




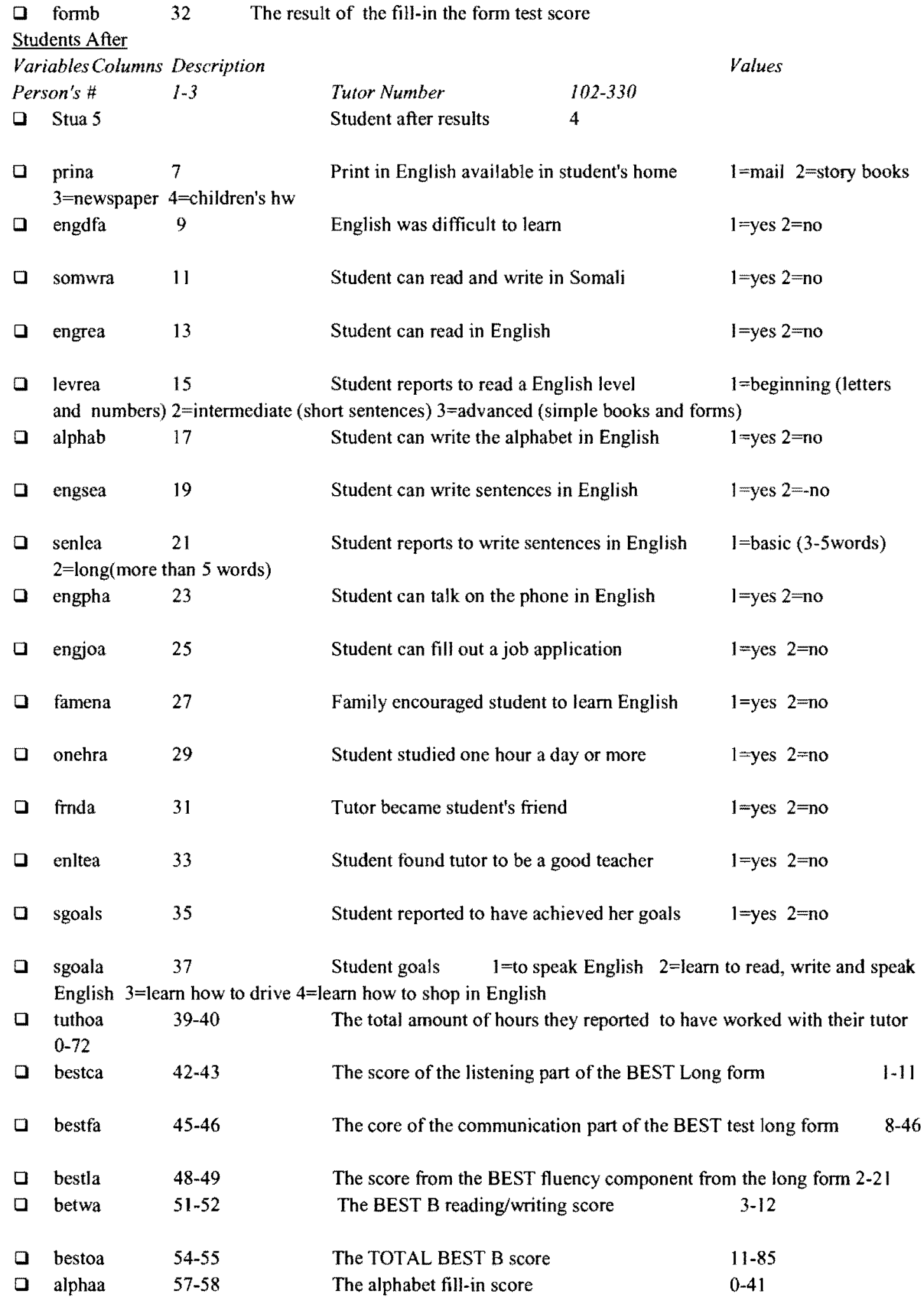


$\square$ forma 59 or less $4=$ perfect

Tutors Before
The result of the fill-in the form test score

For all of the questions: $0=$ no response

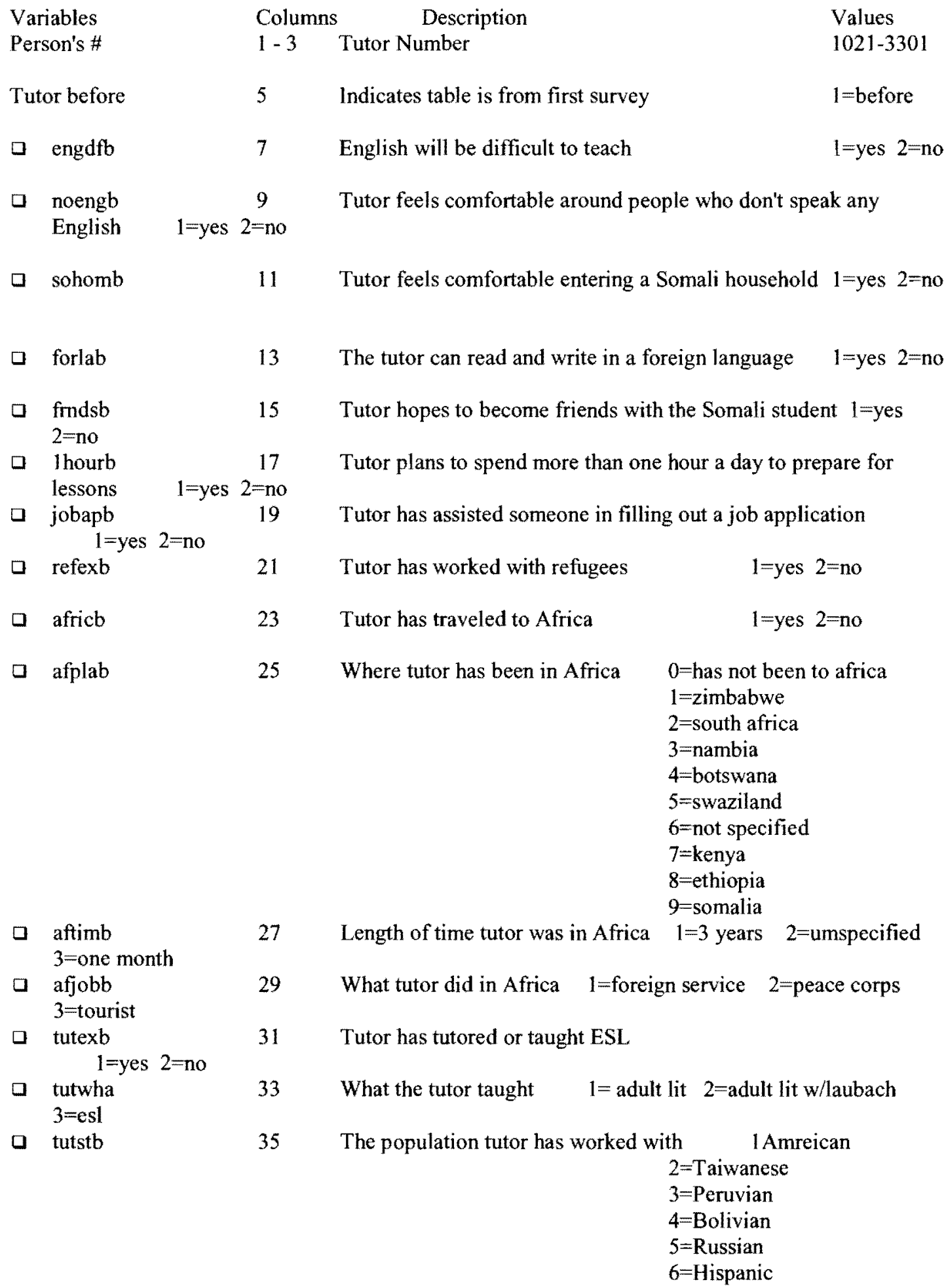




\section{$7=$ Somali}

Tutors After Variables

Person's \#

Columns

Description

Values

$1-3$

Tutor Number

$102-330$

engdfa 4

English was difficult to teach

$1=$ yes $2=$ no

noenga 5

Tutor is comfortable with people who don't speak any English 1=yes $2=$ no

sohoma 6

Tutor feel comfortable entering a Somali home now

$1=$ yes $2=$ no

forlaa 7

Tutor can read and write in a different language

$1=$ yes $2=$ no

frndsa 8

Tutor and her student became friends

$1=$ yes $2=$ no

1houra 9

Tutor spent more than one hour a day to prepare

$1=$ yes $2=$ no

traiesl 10

Tutor thought ESL training was adequate

$1=$ yes $2=$ no

trailit 11

Tutor thought literacy training was adequate

$1=$ yes $2=$ no

traicul 12

Tutor thought cultural training was adequate

$1=$ yes $2=$ no

lfssup 13

Tutor thought LFS staff support was adequate

$1=$ yes $2=$ no

stuhw 14

Tutor's student did homework and/or studied outside of sessions1=yes

$2=$ no

Student achieved her goals

$1=$ yes $2=$ no

stgoal 15

Tutor liked the program's cause

$1=$ yes $2=$ no

conten 17

Tutor liked the program's content

$1=$ yes $2=$ no

contut 18

Tutor was to continue as a tutor

$1=$ yes $2=$ no 